\title{
Lower and Lower Middle Devonian Rugose Corals of the Central Great Basin
}

GEOLOGICAL SURVEY PROFESSIONAL PAPER 805

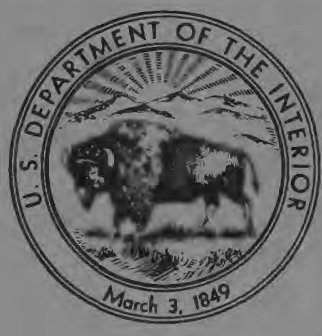




\section{Lower and Lower Middle Devonian Rugose Corals of the Central Great Basin}

By C.W. MERRIAM

GEOLOGICAL SURVEY PROFESSIONAL PAPER 805

A stratigraphic-paleontologic study of rugose corals as aids in age

determination and correlation of

Great Basin Devonian rocks with

those of other regions

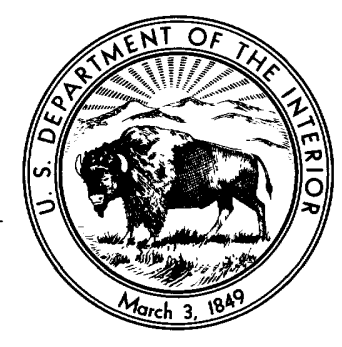




\section{UNITED STATES DEPARTMENT OF THE INTERIOR \\ ROGERS C. B. MORTON, Secretary}

\section{GEOLOGICAL SURVEY}

V. E. McKelvey, Director

Library of Congress catalog-card No. 73-600011

For sale by the Superintendent of Documents, U.S. Government Printing Office

Washington, D.C. 20402 - Price $\$ 2.85$ (paper cover)

Stock Number 2401-02488 


\section{CONTENTS}

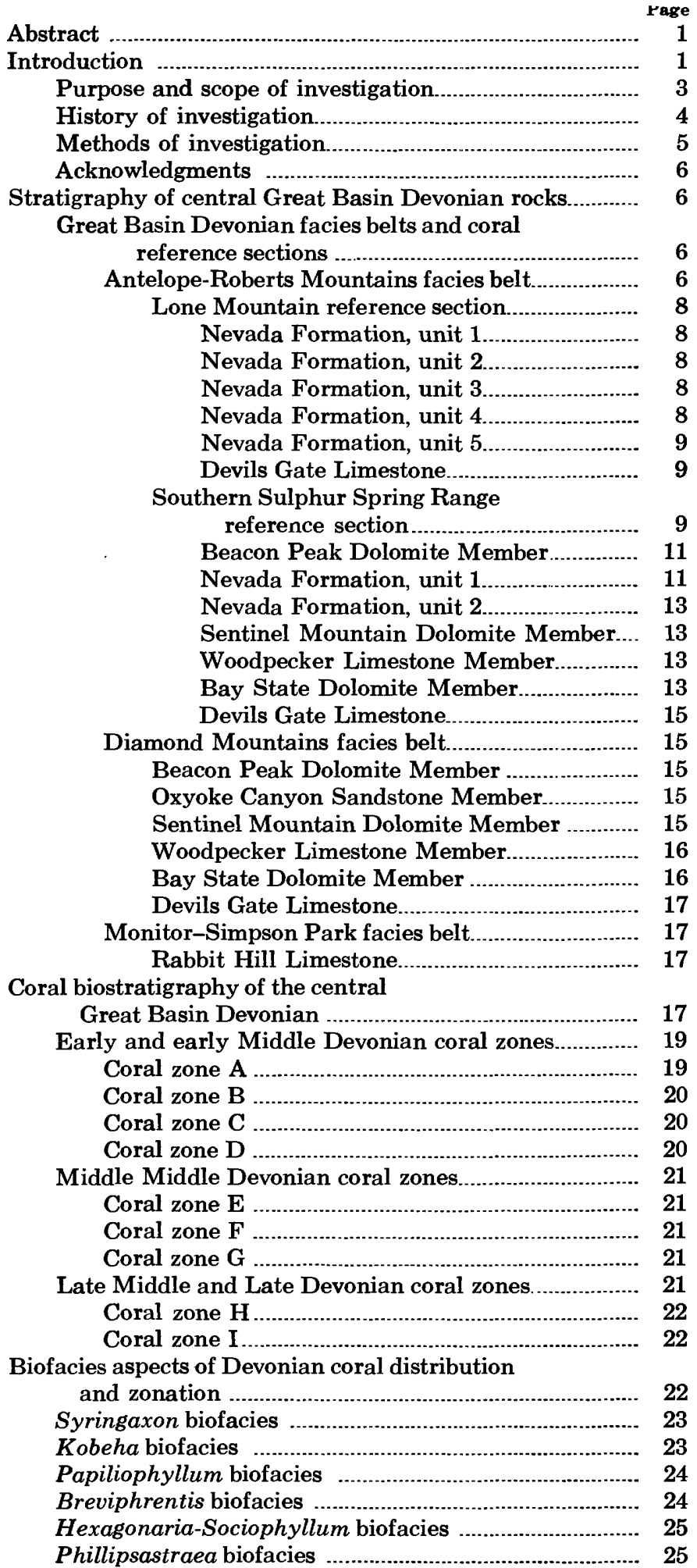

Coral succession and evolution as related to geologic change and faunal migration ..

Page

Coral changes at close of Silurian

Late Silurian and Devonian bursts of rugose coral evolution

Zone D coral burst.

Zone F coral burst.

Zone I coral burst

Age and correlation of Great Basin Early and early

Middle Devonian coral zones.

Age and correlation with distant regions....................... 29

Coral zone A

Coral zone B

Coral zone D

Correlation with other areas in the Cordilleran Belt.... 30

North-central Great Basin ................................... 31

Northern Sulphur Spring Range..................... $\quad 31$

Southern Tuscarora Mountains........................ 31

Cortez Mountains . .......................................... 31

West-central Great Basin..................................... 31

Toiyabe Range ................................................. 31

South-central Great Basin .................................... $\quad 32$

Hot Creek Range ............................................. 32

Southern Great Basin ............................................. 32

Ranger Mountains .......................................... 32

Desert Range .................................................. 32

Northern Panamint Mountains....................... 32

Funeral Mountains ........................................... 32

Northern Inyo Mountains.................................... 33

Systematic and descriptive paleontology ................................ 33

Classification of Great Basin Early and early

Middle Devonian Rugosa ....................................... 33

Taxonomic interpretation of rugose coral structure....... 34

Exterior corallum features ................................... 34

Taxonomic evaluation of corallum interior structures ................................................ 35

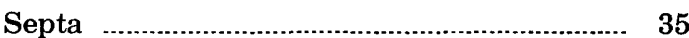

Tabulae ........................................................... 36

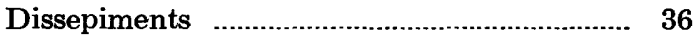

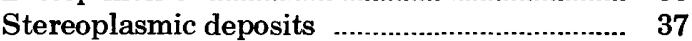

Rugose coral symmetry and taxonomy.................. 37

Growth changes and reproductive features........... $\quad 37$

Variation and dimorphism.................................... 38

Descriptive terms ......................................................... 38

Family Laccophyllidae ................................................. 38

Genus Syringaxon .............................................. $\quad 39$

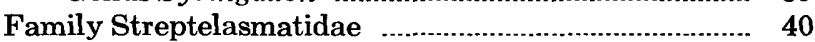

Subfamily Siphonophrentinae ............................. 41

Genus Siphonophrentis ................................. 41 Subgenus Breviphrentis .......................... 42

Genus Nevadaphyllum ................................... 44

Family Kodonophyllidae ............................................. 44

Family Stauriidae ........................................................ 45

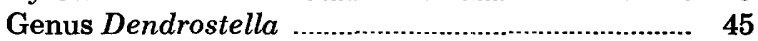

Family Halliidae ........................................................ 46

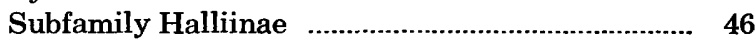


Systematic and descriptive paleontology-Continued

Family Halliidae-Continued

Subfamily Halliinae-Continued

Genus Aulacophyllum

Genus Odontophyllum

Subfamily Papiliophyllinae

Genus Kobeha

Genus Papiliophyllum

Genus Eurekaphyllum

Family Bethanyphyllidae

Genus Bethanyphyllum

Family Chonophyllidae

Genus Sinospongophyllum

Family Endophyllidae

Genus Australophyllum

Family Disphyllidae

Genus Disphyllum
Page

Systematic and descriptive paleontology-Continued

Family Disphyllidae-Continued

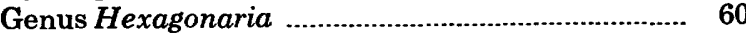

Subgenus Pinyonastraea ................................ 61

Genus Billingsastraea ............................................ 62

Family Cystiphylloidae ....

Genus Cystiphylloides ….................................... 65

Family Digonophyllidae ............................................. 67

Subfamily Digonophyllinae ................................ 67

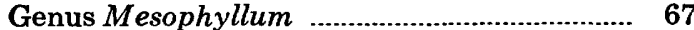

Subgenus Mesophyllum sensu stricto...... 68

Subgenus Arcophyllum .......................... 68

Subfamily Zonophyllinae ......................................... 70

Genus Zonophyllum ..................................... 70

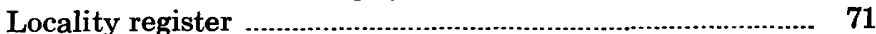

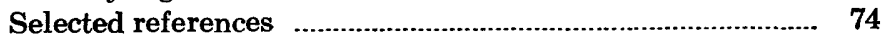

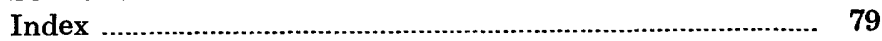

\section{ILLUSTRATIONS}

[Plates follow index]

Plate 1. Syringaxon.

2. Kobeha and siphonophrentoid coral.

3. Kobeha.

4. Kobeha.

5. Kobeha.

6. Kobeha.

7. Papiliophyllum.

8. Papiliophyllum and Eurekaphyllum.

9. Odontophyllum, Aulacophyllum and Aulacophyllum-like rugose corals.

10. Bethanyphyllum.

11. Bethanyphyllum.

12. Bethanyphyllum.

13. (?)Kodonophyllum, Nevadaphyllum, Nevadaphyllum-like rugose coral, and Bethanyphyllum.

14. Siphonophrentis (Breviphrentis).

15. Siphonophrentis (Breviphrentis).

16. Siphonophrentis (Breviphrentis)

17. Sinospongophyllum and Siphonophrentis (Breviphrentis).

18. Dendrostella and Disphyllum.

19. Cystiphylloides.

20. Cystiphylloides and Zonophyllum.

21. Mesophyllum and Mesophyllum (Arcophyllum).

22. Mesophyllum (Arcophyllum).

23. Cystiphylloides and Hexagonaria (Pinyonastraea).

24. Billingsastraea.

25. Australophyllum, Billingsastraea?, and (?) Hexagonaria.

FiguRE 1. Index map showing occurrences of Lower and lower Middle Devonian rugose corals in the central and southern Great Basin.

2. Map showing distribution of Lower and lower Middle Devonian marine facies belts in the central Great Basin... 7

3. Geologic map and cross section of part of Lone Mountain showing lithologic units in the Nevada Formation ......... 10

4. Geologic sketch map showing Silurian and Devonian units in southern Sulphur Spring Range................................ 12

5. Geologic cross section showing Devonian stratigraphic units and coral zones in the southern Sulphur Spring Range

6. Columnar diagram showing relationships of the Devonian reference sections of Lone Mountain and Sulphur Spring Range to Devonian sections of the Monitor Range

7. Columnar diagram showing relationship of the Devonian reference sections of Lone Mountain and

Sulphur Spring Range to that of the Diamond Mountains facies belt at Oxyoke Canyon 
FIGURE 8. Diagram showing the Great Basin Devonian coral zones, equivalent rock units, coral biofacies, and previously employed biostratigraphic designations.

9. Characteristic rugose coral genera of central Great Basin Late Silurian, Early Devonian, Middle Devonian, and Late Devonian coral zones, showing known and inferred vertical ranges

\section{TABLE}

TABLE 1. Evolutionary coral bursts in the Great Basin during the Silurian and Devonian Periods 


\title{
LOWER AND LOWER MIDDLE DEVONIAN RUGOSE CORALS OF THE CENTRAL GREAT BASIN
}

\author{
By C. W. MERriam
}

\section{ABSTRACT}

Rugose corals of the Great Basin Devonian seaways underwent three major bursts of evolutionary activity: (1) in late Early to early Middle Devonian (early Eifelian) time; (2) in the medial Middle Devonian (late Eifelian); (3) in Late Devonian (Frasnian) time. No Rugosa are known in the highest Devonian (Famennian) of this province. The product of the first of these bursts of evolution is part of the subject of this paper.

Devonian rocks of the central Great Basin occur in three north-south facies belts of which the Antelope-Roberts Mountains belt is the more important in terms of Early and Middle Devonian coral distribution. No Rugosa were found in Early and early Middle Devonian rocks of this age of the Diamond Mountains facies belt on the east, where strata of this age are barren dolomite and siliceous sandstone. Within the MonitorSimpson Park facies belt on the west, only the earliest Devon-

Halliidae are especially characteristic of Early Devonian beds in coral zones B and C. The small solitary Syringaxon of the Laccophyllidae is the only rugose coral in most deposits of coral zone A. Locally, however, the compound genus Australophyllum of the Endophyllidae carries over from Late Silurian coral zone $\mathbf{E}$ to the Early Devonian Rabbit Hill of Devonian coral zone A.

Of Early Devonian Halliidae, the endemic Kobeha and Papiliophyllum are known only in the Great Basin province. Corals of the subfamily Siphonophrentinae of the Streptelasmatidae are abundant in coral zones $\mathrm{C}$ and $\mathrm{D}$ where they paralleled the Onondaga and older members of this subfamily in eastern North America. Billingsastraea nevadensis of coral zone $D$ is similar to species in somewhat older beds of eastern North America. Coral zone D Digonophyllidae of the genera Mesophyllum and Zonophyllum are significant ties with the Rhine Valley Middle Devonian of western Europe.
\end{abstract} ian Rabbit Hill Limestone coral fauna is known.

Nine successive coral zones are defined in the Nevada Formation and overlying Devils Gate Limestone of the AntelopeRoberts Mountains belt. These zones have been designated A through $I$ in ascending stratigraphic order. Described and illustrated herein are Rugosa and Early Devonian coral zones A, $B$, and $C$ and those of coral zone D, which is Early and early Middle Devonian. Rugosa of coral zone A are best known in the westerly Monitor-Simpson Park belt, where they characterize the Syringaxon facies of the Helderbergian Rabbit Hill Limestone.

The first great burst of Devonian coral activity is that of coral zone $\mathrm{D}$, followed by an even greater differentiation of certain families in coral zone $F$, which is marked by spread of the Disphyllidae and Digonophyllidae and disappearance of Halliidae and Bethanyphyllidae of the older coral zones. Late Devonian strata of coral zone I have few surviving rugose coral families. However, the newly arrived and very distinctive Phillipsastraeidae evolved rapidly and became abundant as colonial and solitary forms here as in most of the Late Devonian throughout the world. No Rugosa have been found in the latest Devonian of the Great Basin.

Of 13 families of Rugosa in the Great Basin Silurian, 8 do not continue on in the Devonian. Eleven Devonian rugose coral families are described in the Great Basin province, of which only the Laccophyllidae, Streptelasmatidae, and Chonophyllidae carry over from the Silurian as major Devonian groups. By early Middle Devonian time five new families have appeared: Halliidae, Bethanyphyllidae, Disphyllidae, Cystiphylloidae, and Digonophyllidae. These may have evolved from such Silurian stocks as the Lykophyllidae, Kyphophyllidae, and Cystiphyllidae.

\section{INTRODUCTION}

Corals are among the common fossils in Great Basin Devonian rocks. Of the two extinct Paleozoic Orders, Tabulata and Rugosa, the first is more abundantly represented, but the Rugosa by reason of their morphologic diversity, more complex internal features, and greater evolutionary plasticity prove to be a more rewarding subject for stratigraphic paleontology and provide better material for taxonomic study and investigation of evolutionary trends through the Devonian strata.

Like present-day Zoantharia, the extinct Rugosa were beyond doubt highly sensitive to environmental vicissitudes, and their geographic-stratigraphic discontinuities within the Great Basin Devonian clearly reflect environmental control. Within the Great Basin geologic province (fig. 1), the central Great Basin Devonian includes a great diversity of marine rock types or lithofacies and illustrates better than other parts of the province a wide range of coral biofacies. For example, the sandstones and dolomites of Early and early Middle Devonian age in the Diamond Mountains facies belt have yielded no rugose corals. To the west, however, in the impure limestones of the Antelope-Roberts Mountains facies belt (fig. 2), corals become abundant and taxonomically diverse within 


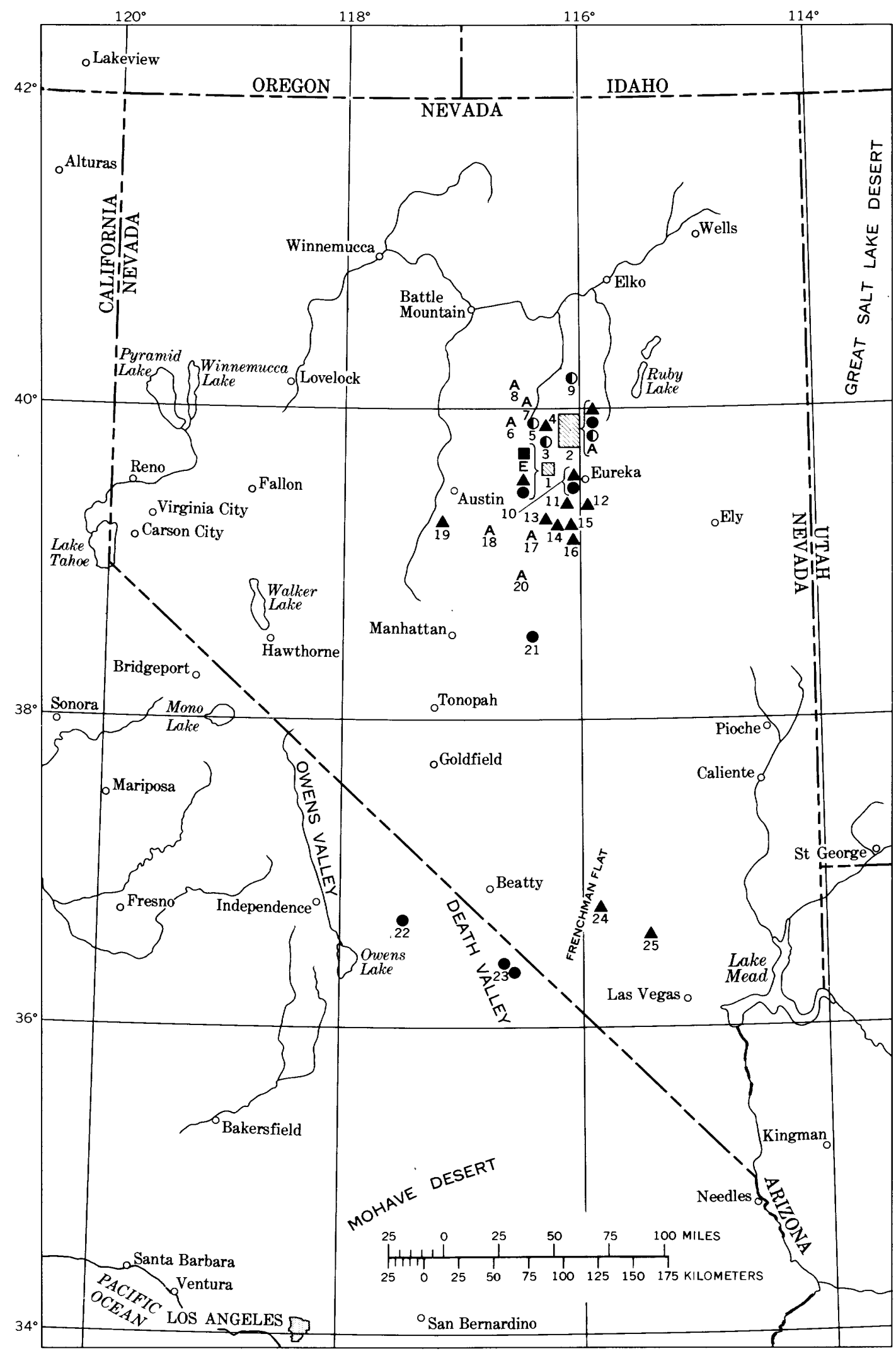

FIGURE 1.-Index map showing occurrences of Lower and lower Middle Devonian rugose corals in the central and southern Great Basin. Symbols indicate Devonian coral zone. 


\section{EXPLANATION \\ LOWER AND LOWER MIDDLE DEVONIAN RUGOSE CORAL OCCURRENCES}

- Coral zone F, Middle Devonian (Eifelian)

E Coral zone E, Middle Devonian

- Coral zone D, late Early and Middle Devonian

- Coral zone C, late Early Devonian

D Coral zone B, Early Devonian (Oriskany)

A Coral zone A, Early Devonian (Helderberg)

NUMBERED LOCALITIES

1. Lone Mountain map area (see fig. 3)

2. Southern Sulphur Spring Range map area (see fig.4)

3. Roberts Creek Ranch (M1042)

4. Roberts Mts., Cooper Peak area (M1073)

5. Roberts Mts., Niel Creek area (M1072)

6. Simpson Park Mts., Walti Ranch (M1074)

7. Simpson Park Mts., Coal Canyon (M1075)

8. Cortez Mts., (M1083)

9. Mineral Hill area; McColley Canyon

10. Modoc Peak (M1071)

11. Combs Peak (M27)

12. Grays Canyon (M3; M51)

13. Northern Antelope Range (M1035)

14. Northern Antelope Range (M1053)

15. Fish Creek Range (M1033)

16. Cockalorum Wash area, southeast of Eightmile Well

17. Rabbit Hill (M48; M187)

18. Northern Toquima Range, Petes Canyon area (M1150)

19. Toiyabe Range, west side south of Reeds Canyon (M1151)

20. Dobbin Summit (M1067; M1068; M1069)

21. Hot Creek Canyon (M1066)

22. Northern Panamint Range (M184; M1065)

23. Funeral Mts. (M1059; M1060; M1061; M1062; M1063; M1064)

24. Ranger Mts. (M1034; M1058)

25. Desert Range (M1057)

Note: Numbers preceded by $\mathrm{M}$ are

USGS (Menlo Park) fossil localities

about the same stratigraphic interval. Yet, farther west, rugose coral faunas of limestones characterizing the Monitor-Simpson Park facies belt are extremely restricted taxonomically; most sections contain but a single genus of small solitary coral.

In a time-rock sense a great part of the Devonian is doubtless recorded by the 3,500-4,000 feet of marine strata which make up the system in this province (Merriam, 1940). Dolomite and limestone of shallowwater shelf environments predominate. The Devonian dolomite, which is mainly of diagenetic origin, especially characterizes the eastern Great Basin; for the province as a whole, diagenetic dolomite occupies a greater outcrop area than limestone. Where dolomite and limestone facies come together in the central Great Basin, the vertical and lateral changes are complex; within this belt of unstable, fluctuating environment the vertical range and geographic spread of coral species were greatly affected by facies restrictions.
Corals are more conspicuous on the outcrop and are seemingly more numerous in Devonian argillaceous and silty limestones than in the cleaner carbonate rocks. To some extent this seeming fossil abundance may be misleading. The collector soon recognizes that fossils weather free and are more easily obtainable on the shaly, rubbly erosion surfaces formed by argillaceous limestones than on the denser, less impure, albeit fossil-rich carbonate rocks. In the past most Great Basin Devonian fossil collecting by geological exploring parties was from loose weathered material of this nature.

Systematic fossil collecting during the 1930's in conjunction with geologic mapping of central Nevada Devonian rocks demonstrated the stratigraphic utility of rugose corals and was the initial inspiration for this project. More recently the Cordilleran Rugosa of Silurian and Devonian ages and those of eastern North America became the subject of detailed research by several coral specialists. Progress since 1940 in the light of world advances in the knowledge of rugose coral structure, classification, stratigraphic distribution, and ecology makes possible a more meaningful approach to continued study of western Rugosa than would earlier have been possible.

\section{PURPOSE AND SCOPE OF INVESTIGATION}

The primary objectives of this study are the description, classification, and illustration of Great Basin Lower and lower Middle Devonian Rugosa in accordance with modern standards and techniques, together with the interpretation of their evolutionary history in the light of new knowledge of their stratigraphic ranges and geographic occurrences. A proposed zonation based on the corals is the chief product of these paleontologic researches; in addition, geologic mapping and structural interpretation of the areas in which the Devonian reference sections are situated have been accomplished.

Study of the Devonian rugose corals and their ecologic associates has an important bearing upon geologic correlation of the Great Basin strata with strata elsewhere in the Cordilleran belt and with standard Devonian sections in eastern North America and Europe, especially in the Rhine Valley region. These studies point up the endemic character of some Great Basin coral genera and the more cosmopolitan nature of others.

In this report the descriptive and taxonomic paleontology includes only the rugose corals of the Rabbit Hill Limestone and the lower half of the Nevada Formation; the "barren zone" or coral zone $\mathrm{E}$ is an appropriate cutoff horizon above which entirely different coral faunas were introduced. 


\section{HISTORY OF INVESTIGATION}

Study of Great Basin Devonian rugose corals began with Meek's (1877, p. 25-33, pl. II) description of Upper Devonian species collected in the White Pine mining district, Nevada, by the 40th Parallel party. Meek was guided in this modest contribution by the memoirs of Edwards and Haime $(1851 ; 1850-54)$, whose works set high standards for coral research and remained the authoritative references on this subject for more than a half century.

Coral-rich Devonian strata, the subject of this report, were discovered by pioneering geologists who made the first topographic and geologic map of the Eureka mining district, Nevada, in the 1880's (Hague, 1892). Paleozoic coral research was at that time in a static phase, largely because of technical difficulties in thin-section preparation. Although large collections of loose corals were zealously made by Walcott and his field associates, it is not surprising to find that "Paleontology of the Eureka District" (Walcott, 1884, p. 104-106), published an amazingly short time after fieldwork, gave scant attention to the rugose corals. None were illustrated.

The Eureka district Devonian coral material deposited in the U.S. National Museum was supplemented considerably during the 1920's by the efforts of Edwin Kirk of the U.S. Geological Survey, who revisited many of Walcott's localities and discovered new localities in outlying areas. At Kirk's suggestion, the writer in 1933 began a program of sectioning and study of Lower and lower Middle Devonian Rugosa collected in the course of a geologic reconnaissance of the Roberts Mountains. Comparisons were made with the Eureka material and with Great Basin material collected by earlier Great Basin exploring parties. (The earlier material was also on deposit in the Smithsonian.) At the outset of this program it became evident that the older Eureka district collections had limited stratigraphic value, because of the manner in which collecting and reconnaissance geology were done in the 1880's. Some of the collections rather certainly represent fossils taken from 100 feet to several hundreds of feet of strata, but they are included in a single lot; hence, cautious evaluation and sorting is required for purposes of detailed stratigraphy and ecologic association by present standards. ${ }^{1}$

Systematic thin-section study of American Devon-

\footnotetext{
1According to Edwin Kirk (oral commun., 1935; written commun., 1954), Walcott had described to him the manner in which some of the Devonian fossil collecting was done at Lone Mountain and at the Eureka vicinity. Several U.S. Naval Academy midshipmen attached to the Hague party for summer engineering experience were assigned to fossil collecting under Walcott' supervision. Large piles of corals and other fossls, found at central location on the outco
}

ian corals was little advanced at the inception of this investigation in 1933. Few published descriptions were accompanied by adequate illustration of internal corallum structure, thus preventing meaningful comparison. Progress in Europe was more rapid. A milestone in Paleozoic coral research was the burst of activity at Marburg, Germany, by Rudolf Wedekind and his colleagues during the 1920-36 period. Detailed descriptions and thin-section illustrations of Rhine Valley Devonian Rugosa by these workers have had special value in connection with identification and classification of Great Basin and other American farwestern forms. Although the coral taxa of Wedekind and his associates are keyed to stratigraphic units and have value as zonal indices, their excessive generic splitting is a controversial feature. Doubtless many Wedekind genera will eventually be reduced in rank or combined in synonymy by more conservative workers (Birenheide, 1962a; 1964).

Stumm's $(1937 ; 1938 ; 1940)$ descriptive work on Devonian rugose corals of the Eureka district and adjacent areas dealt mainly with the Smithsonian collections mentioned above. These contributions placed on record previously unknown Early and Middle Devonian genera and provided a foundation for continued taxonomic work upon these partly endemic Great Basin forms.

Since 1940 general progress in the understanding of the Rugosa has been great, with a rapidly expanding world literature, some of which is referred to in the section "Systematic and Descriptive Paleontology." Among indispensable compendia are:

(1) "Index of Paleozoic Coral Genera," by Lang, Smith, and Thomas (1940).

(2) "Revisions of the Families and Genera of the Devonian Tetracorals," by Stumm (1949).

(3) "Rugosa," by Hill (1956) in "Treatise on Invertebrate Paleontology."

To a considerable extent these Great Basin Silurian and Devonian coral studies were a product of geologic mapping and stratigraphy which were stimulated by economic and resource factors. Search for petroleum and metals in the Great Basin and successful oil exploration in Devonian rocks of western Canada within the past 25 years have encouraged study of all aspects of the stratigraphy and paleontology. For the first time meaningful comparison of Great Basin faunas with those of the northern Cordilleran Belt has become possible. Thus far close paleontologic similarities are evident mainly among higher Middle and Upper Devonian species, rather than among fossils of the lower zones here dealt with.

Most of the corals described and figured herein 
were collected after 1947, during the course of geologic mapping and stratigraphic investigation in the Eureka mining district, Nevada, and adjacent areas by the writer in conjunction with the detailed geologic mapping program of T. B. Nolan. Central Great Basin Devonian collections were supplemented from time to time by coral material collected by U.S. Geological Survey mapping parties in other parts of the province. In 1959 the mapping and stratigraphic effort involving Silurian and Devonian rocks of six 15-minute quadrangles west of the Eureka mining district was revitalized under the Kobeh Valley project of Nolan and Merriam.

\section{METHODS OF INVESTIGATION}

Understanding the fossil distribution in the greatly dislocated strata of the Great Basin Paleozoic requires fairly detailed geologic mapping in order to set up reliable reference sections. At best the standard paleontologic column is a composite of stratigraphic segments in disconnected structural blocks. Further complexities are introduced by profound facies changes, as for example the almost complete disappearance of siliceous sandstone in the Lower Devonian between the Diamond Mountains and Lone Mountain. Dependable key beds with great lateral continuity are uncommon in the Devonian rocks of this vicinity. Attempts have been made to relate fossil occurrences to structure sections prepared in the advanced stages of the mapping procedure.

Stratigraphic data applicable to Devonian rugose coral zonation have accrued from geologic mapping since 1959 in the Whistler Mountain, Bartine Ranch, and parts of the Garden Valley and Cockalorum Wash quadrangles. Much light is shed upon the profound Lower Devonian facies changes by the mapping of T. B. Nolan near Eureka, especially in the southernmost Diamond Mountains in the Pinto Summit quadrangle.

The more continuous measurable Devonian sections within this region of thrust faulting occupy carbonate autochthons. Like the central mass of Lone Mountain (fig. 3), these more rigid strata are little deformed by thrusting, but they are cut by innumerable high-angle faults which break stratigraphic continuity. In this connection Lone Mountain, including the primary Devonian coral reference section, has been separately mapped.

Lone Mountain provides an excellent example of highly complex Great Basin geologic structure wherein stratigraphic sections unaffected by pervasive thrust and normal faulting are indeed exceptional. The central part of the mountain is a fairly straightforward homocline of marine beds, mostly carbonate, ranging in age from early Middle Ordovician to late Middle Devonian. However, the lower or pediment slopes reveal an entirely different and highly complex pattern of thrusting which involves Ordovician graptolitic beds, Permian limestones, and Devonian limestones. Lone Mountain discloses to advantage the characteristic structure pattern of the region - thrusting followed by high-angle, mostly normal, faulting.

To the south beyond the limits of this study in the Fish Creek Range occur Middle Devonian rocks of coral zone $F$, lithologically quite different from the normal autochthonous carbonates of this interval; these highly deformed southern partly argillaceous facies occupy what appear to be major thrust plates.

Coral collecting by the writer and associates during the initial phase of this study (Merriam, 1940) was in considerable part from loose weathered material, precise stratigraphic horizon not being rigorously determined. In later years more of the collecting was done bed-by-bed on measured sections to secure in situ associations, a procedure greatly facilitated by new and accurate topographic maps. Whereas sections were measured by tape and Brunton for collecting purposes within the mapped areas, large-scale map location of collecting sites was found to be more reliable because of pervasive faulting, which was difficult to recognize or interpret where stratigraphic observations are confined to individual traverse courses.

Little progress has been made in biofacies study of the Great Basin rugose corals and their ecologic associates. Whereas Rugosa are dominant megafossils in some lithologic units, in others they are numerically less important elements of varied assemblages containing corals, brachiopods, mollusks, and trilobites. A good biofacies indicator is Syringaxon of the Early Devonian Rabbit Hill Limestone, in which this abundant small solitary genus is normally the only rugose coral. By contrast coral zone $\mathrm{F}$ of the higher Middle Devonian contains locally abundant large compound genera in a potentially reef-forming biota.

With regard to relative age and correlation values of the several phyla, it may be said that specialist conclusions based upon independent study of separate fossil categories have not always agreed with those founded upon rugose coral research. Converging and adjusted conclusions from research upon all the major fossil categories are needed. Some corals are perhaps better indicators of specific environments than precise geologic age. In this work the associated brachiopods have been utilized largely to support the coral evidence for correlation and age. 


\section{ACKNOWLEDGMENTS}

Among Great Basin workers whose rugose coral collections have added materially to this study are the following: J. F. McAllister, Panamint Range and Funeral Mountains; M. S. Johnson and D. E. Hibbard, Ranger Mountains; F. G. Poole, Ranger Mountains; C. R. Longwell, Desert Range; F. J. Kleinhampl, Monitor Range; H. E. Cook, Hot Creek Range; R. H. Washburn, Toiyabe Range; J. H. Stewart and E. H. McKee, Toiyabe and Toquima Ranges; T. B. Nolan, Eureka mining district; and A. J. Boucot and J. G. Johnson, northern Sulphur Spring Range and Cortez Mountains.

An earlier draft of this report was read by the late E. C. Stumm of the University of Michigan, whose constructive suggestions regarding taxonomic matters are appreciated. D. J. McLaren of the Geological Survey of Canada has been most helpful in providing information on the type species of Cystiphylloides and other genera of Devonian rugose corals.

All photographic illustrations are the work of Kenji Sakamoto of the U.S. Geological Survey, Menlo Park, Calif.

\section{STRATIGRAPHY OF CENTRAL GREAT BASIN DEVONIAN ROCKS}

Coral-bearing Devonian formations of the central Great Basin are in ascending stratigraphic order as follows: (1) Rabbit Hill Limestone of Early Devonian (Helderberg) age; (2) Nevada Formation of Early and Middle Devonian age; and (3) Devils Gate Limestone of late Middle and Late Devonian age. Physical characteristics of these formations have been described in other reports (Merriam, 1940, 1963; Nolan and others, 1956) together with details of their areal distribution and geologic structure. The Lone Mountain and Sulphur Spring Range reference columns are adopted as joint primary yardsticks for these rocks, supplemented by partial sections in the Devils Gate area and in the northern Monitor Range.

With reference to Early and early Middle Devonian coral-bearing strata dealt with in this report, approximately correlative noncoralline rocks in the Diamond Mountains to the east comprise entirely different dolomite and sandstone facies. To the west in the Monitor and Simpson Park Ranges, the Early Devonian Rabbit Hill Limestone represents yet another facies belt.

In the Sulphur Spring Range the Early and early Middle Devonian beds most closely resemble, both lithologically and faunally, those of the Lone Mountain yardstick, but fortunately include westerlyreaching quartzitic sandstone tongues from the Diamond Mountains belt as well as easterly extending beds which carry elements of the Rabbit Hill Helderbergian fauna of the Monitor-Simpson Park belt. Hence in this key reference column of the Sulphur Spring Range, lithologic and paleontologic features of all these facies belts are rather satisfactorily united.

Most of the stratigraphic units and coral zones treated in this report occur within the Nevada Formation of Early and Middle Devonian age, as earlier redefined by Nolan, Merriam, and Williams (1956, p. 40-48). On the basis of lithology and fossils, this formation has been subdivided vertically and laterally in considerable detail. Its more characteristic facies lie within the Antelope-Roberts Mountains belt, but the easterly Diamond Mountains dolomite-arenaceous facies are also included in the Nevada Formation. The westerly Helderbergian Rabbit Hill Limestone is geographically separate and, except for its presence in th northernmost Simpson Park Mountains, is not known to be present in sections containing the Nevada Formation. Beds with Rabbit Hill fossils earlier mentioned in the Sulphur Spring Range are more closely allied lithologically to the Beacon Peak Dolomite Member of the Nevada Formation as defined within the Diamond Mountains facies belt.

\section{GREAT BASIN DEVONIAN FACIES BELTS AND CORAL REFERENCE SECTIONS}

For purposes of this discussion, Devonian strata of the central Great Basin may be treated in accordance with its distribution in three subparallel facies belts (fig. 2) as follows:

1. Antelope-Roberts Mountains facies belt,

2. Diamond Mountains facies belt,

3. Monitor-Simpson Park facies belt.

Each facies belt possesses distinctive lithologic, structural, and paleontologic characteristics. Whereas north-south subparallel alinement of the belts is today geomorphic-orographic, it may to some extent reflect the predeformation distribution pattern of sedimentation in shelf seaways of Devonian time.

\section{ANTELOPE-ROBERTS MOUNTAINS FACIES BELT}

The Antelope-Roberts Mountains belt stretches south for about 90 miles from the Sulphur Spring Range and Roberts Mountains, through the Fish Creek Range and the Antelope Range. The strata of this belt probably extend southward in the littleexplored Hot Creek Range. In a time-rock sense nearly all the Devonian System as known in the Great Basin is represented within the Antelope-Roberts Mountains facies belt. A possible exception is the latest Devonian of the upper Pilot Shale. Characteristic are the fossilrich silty and argillaceous limestones of Nevada 


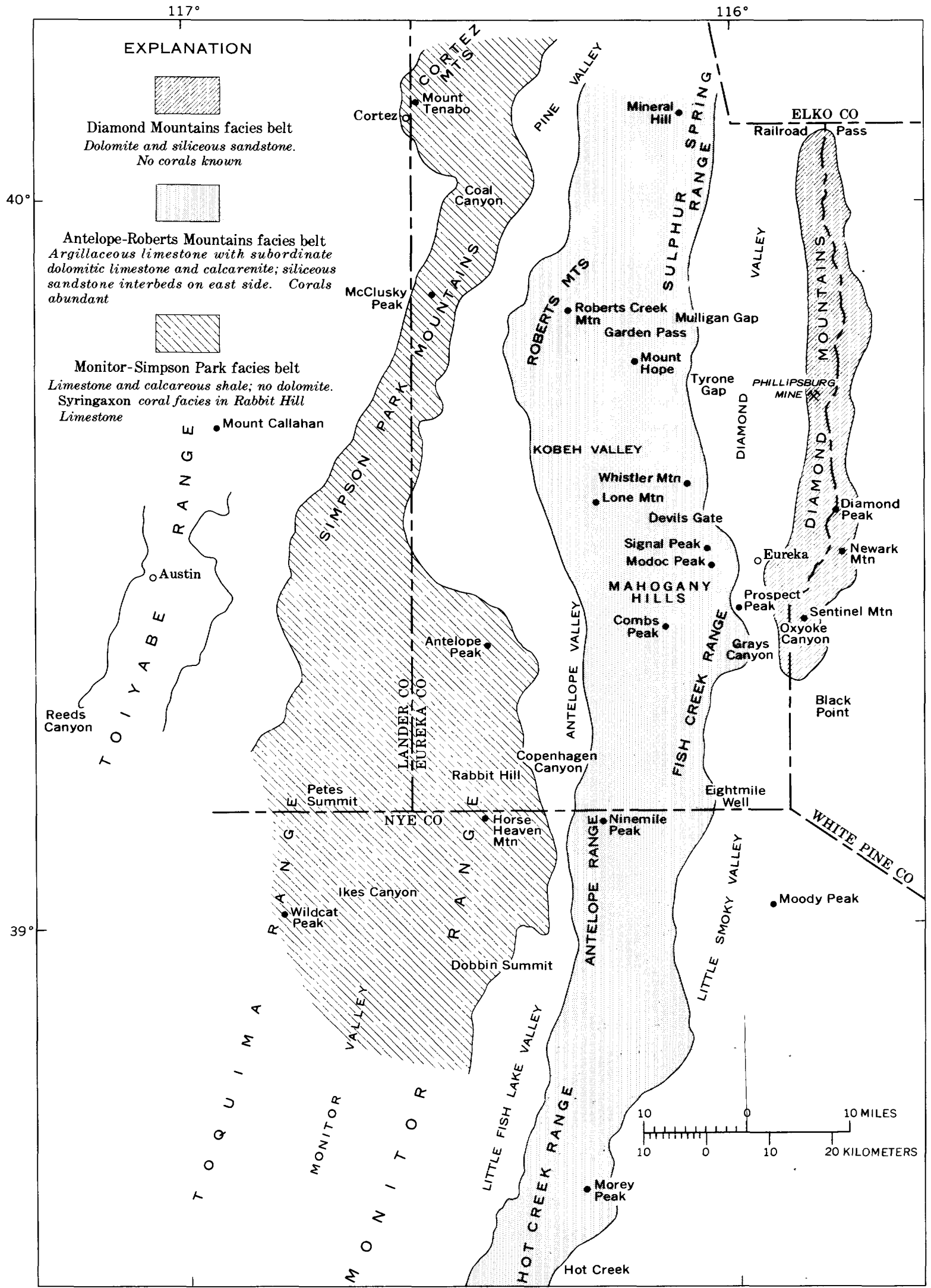

Figure 2.-Distribution of Lower and lower Middle Devonian marine facies belts in the central Great Basin. 
Formation, unit 2, which have not been recognized in the other belts. Present along its eastern margin are quartzitic sandstone and dolomite tongues interpreted as westerly facies extensions from the Diamond Mountains belt. Situated within this belt are the primary coral reference sections for the Lower and lower Middle Devonian at Lone Mountain and in the southern Sulphur Spring Range.

\section{LONE MOUNTAIN REFERENCE SECTION}

Five lithologic units have been used in the detailed geologic mapping of the Nevada Formation at Lone Mountain (fig. 3), each characterized by distinctive rugose corals and other fossils. The stratigraphy and paleontology are better understood here than at Modoc Peak, where the Nevada Formation type section was earlier designated (Merriam, 1940, p. 15). However, the Modoc section is in other ways somewhat more representative of the formation as a whole, for it includes a quartzitic sandstone member of the easterly Diamond Mountains facies, a tongue which feathers out completely before reaching Lone Mountain. The map divisions of the Nevada Formation at Lone Mountain are designated units 1 through 5 in ascending order.

The basal dolomite of unit 1 rests with a seemingly gradational boundary upon the upper beds of the Lone Mountain Dolomite. These lower Nevada dolomites contain the Papiliophyllum fauna of coral zone $\mathrm{C}$, and the Acrospirifer kobehana fauna of about Emsian age. No depositional record of the Rabbit Hill Limestone or of the Beacon Peak Dolomite Member, each with a Helderbergian fauna and coral zone A, has been recognized here at Lone Mountain where they would be expected just above the Lone Mountain Dolomite. Likewise, coral zone B with Kobeha is not represented by conclusively identifiable fossils. No physical evidence of disconformity was found here at the Lone Mountain Dolomite-Nevada Formation boundary.

\section{Nevada Formation, unit 1}

The lower unit of the Nevada Formation (fig. 3) is about 260 feet thick in Coral Gulch on the south side of Lone Mountain, where it consists of thick-bedded blocky dolomite, dolomitic limestone, and limestone of light-gray to mouse-gray color. Lower beds of unit 1 have much the same appearance as the underlying Lone Mountain Dolomite, with which it appears to be gradational at this locality. A disconformity separates these two formations in the Mahogany Hills and in the Diamond Mountains belt. Argillaceous matter is present in the upper beds of this unit where it grades into unit 2.

Unit 1 becomes less dolomitic traced northwest toward Contact Gulch. Gray chert nodules flattened parallel to the bedding are characteristic, and the fossils are generally silicified. Chert and fossils weather limonite brown.

The lowest identifiable fossils collected from unit 1 at Lone Mountain represent coral zone C. Poorly preserved large horn corals at the base may be in coral zone B. In the Sulphur Spring Range calcarenite with scattered rounded quartz grains occurs at the bottom of unit 1 and contains the Kobeha fauna of coral zone $\mathrm{B}$ with Costispirifer arenosus.

\section{NeVAda Formation, UNIT 2}

About 720 feet thick, unit 2 is well exposed in upper Coral Gulch and upper Fossil Gulch. Because of its partly argillaceous, thin-bedded, and banded character, the appearance of unit 2 contrasts sharply in outcrop with underlying and overlying thicker bedded units, being more resistant to weathering. The shaly bands yield loose fossils in large numbers; most of the collections first made from the Nevada Formation are from outcrops of this nature. Corals, especially favositid heads, are abundant in many beds; some are in their original upright growth position with their base in a limestone layer, the upper part not uncommonly having been buried by argillaceous sediment. Unit 2 contains the assemblages of coral zone $D$ in which the Rugosa reach a peak of abundance and diversity.

No siliceous sandstone was found in unit 2 at Lone Mountain, but it was found at Combs Peak and Modoc Peak. The eastward increase of siliceous matter, well shown in the southern Sulphur Spring Range, reaches a maximum in the Diamond Mountains southeast of Eureka where the Oxyoke Canyon Sandstone Member probably correlates with some part of unit 2 .

\section{NeVAdA Formation, UNIT 3}

About 285 feet thick, the dark-gray, well-bedded, and relatively nonargillaceous limestone of unit 3 is well exposed on the south side of Lone Mountain, 2,000 feet northeast of West Peak. Many beds and lenses of crinoidal debris in it tend to be massive; otherwise fossils are scarce in unit 3 . Unit 3 has been called the "barren zone" compared with the abundantly fossiliferous units below and above. In the Diamond Mountains at Oxyoke Canyon, the Sentinel Mountain Dolomite Member, has yielded no fossils. It is probably a facies equivalent of unit 3 , but it is completely dolomitized. No dolomite was recognized in unit 3 at Lone Mountain.

\section{NeVAda Formation, unIT 4}

A well-bedded division, unit 4 , is about 675 feet thick at Lone Mountain and crops out along the west 
side of the main ridge between Reef Point and North Peak. Unit 4 includes dense, resistant, fine-grained limestone, dolomitic limestone, and dolomite. The unit ranges in color from dull mouse gray to medium and dark gray, and weathers light gray. These strata include thin-bedded almost shaly intervals and thickbedded massive dolomite lenses. Rugose corals and stromatoporoids are abundant locally within the thickbedded dolomitic bodies. Chert nodules weathering limonite brown are fairly numerous, and fossils are commonly' silicified. Unit 4, with numerous colonial and solitary rugose coral genera, represents Devonian coral zone $\mathrm{F}$, the interval of greatest differentiation of the colonial Rugosa in Middle Devonian time.

In the Fish Creek Range south of Eureka, Middle Devonian beds correlative with the Nevada Formation, unit 4 include black shale and siltstone with light-gray limestone bodies locally rich in rugose corals like those of unit 4 at Lone Mountain. In both places these loci of coralline proliferation suggest incipient bioherms or patch reefs.

The Woodpecker Limestone Member of Nolan, Merriam, and Williams (1956, p. 44) is the equivalent of unit 4 in the Diamond Mountains, where it includes more platy and shaly limestone, some of which is pinkish in color. The thick-bedded dolomitic bodies with a coral biota were not found in the Diamond Mountains facies belt.

\section{NeVAda Formation, UNIT 5}

Unit 5, the uppermost unit of the Nevada Formation, is about $\mathbf{5 7 0}$ feet thick at Lone Mountain and consists of thick-bedded and massive saccharoidal dolomite and dolomitic limestone of dark-, medium-, and light-gray color. Alternation of very dark gray and light-gray thick dolomite beds is characteristic. This resistant unit forms the summit ridge of Lone Mountain between Flag Point and North Peak. It is overlain by massive cliff-forming Devils Gate Limestone, the lowest beds of which are crowded with Amphipora, as is well shown on the first main spur east of Section Ridge (fig. 3).

Unit 5 is sparsely fossiliferous at Lone Mountain. There are scattered deposits of the large brachiopod Stringocephalus. However, the organic structure of brachiopods and stromatoporoids is largely destroyed by dolomitization. The Bay State Dolomite Member of the Diamond Mountains belt is the approximate equivalent of the Nevada Formation, unit 5. Thick beds with Stringocephalus are best shown in that belt. Limestone beds near the base of the Bay State Dolomite Member contain rugose corals of coral zone G and the brachiopod Rensselandia.

\section{Devils Gate Limestone}

The upper Middle and Upper Devonian Devils Gate Limestone (Merriam, 1940, p. 16-17; 1963, p. 49-56) is about 1,200 feet thick and rests conformably upon the dolomites of Nevada Formation, unit 5 at Lone Mountain. It consists mainly of limestone in most localities; locally the lower part has been subjected to patchy, irregular dolomitization (Merriam, 1963, p. 51). At Lone Mountain the Devils Gate is the highest unit of the central autochthon and consists of mediumdark to dark-gray well-bedded limestone with scattered massive, cliff-forming bodies. The topmost strata are not exposed here; these abundantly fossiliferous beds are best seen at Devils Gate or in the Newark Mountain vicinity of the Diamond Mountains, according to Nolan, Merriam, and Williams (1956, p. 48$52)$, where both top and bottom are well exposed.

Clear-cut lithologic subunits are more difficult to define and trace within the Devils Gate Limestone than in the Nevada Formation because of greater rock uniformity in the former. However, the upper 250-300 feet are quite readily separable by somewhat thinner bedding, the presence of dark-gray chert, large lenses and beds of depositional mud-breccia, and the great local abundance of shell fossils. The lower half of the Devils Gate everywhere includes a great deal of limestone formed by massive concentric stromatoporoids and Amphipora as at Lone Mountain, but in general corals and shell fossils are abundant only in widely scattered pockets. It has recently been found that the large brachiopod Stringocephalus, thought previously to be confined to the Nevada Formation, unit 5 (Bay State Dolomite Member), ranges up into thick-bedded massive limestones which characterize the lower third of the Devils Gate at Lone Mountain.

\section{SOUTHERN SULPHUR SPRING RANGE REFERENCE SECTION}

Devonian rocks of the Nevada Formation underlie most of the southern Sulphur Spring Range east of the Mulligan Gap fault (fig. 4). The five Nevada Formation units or their time-stratigraphic equivalents described at Lone Mountain are present, but the Devonian column is more inclusive in the Sulphur Spring Range; stratigraphically beneath the Nevada Formation, unit 1 are dolomites and dolomitic limestones containing Helderbergian Rabbit Hill fossils. These earliest Devonian beds (for this region) are not found at Lone Mountain and are assigned to the Beacon Peak Dolomite Member. In the Diamond Mountains facies belt where the Beacon Peak is described, it is the lowermost member of the Nevada Formation. The overall lithologic makeup of the reference section of the Sulphur Spring Range Devonian 

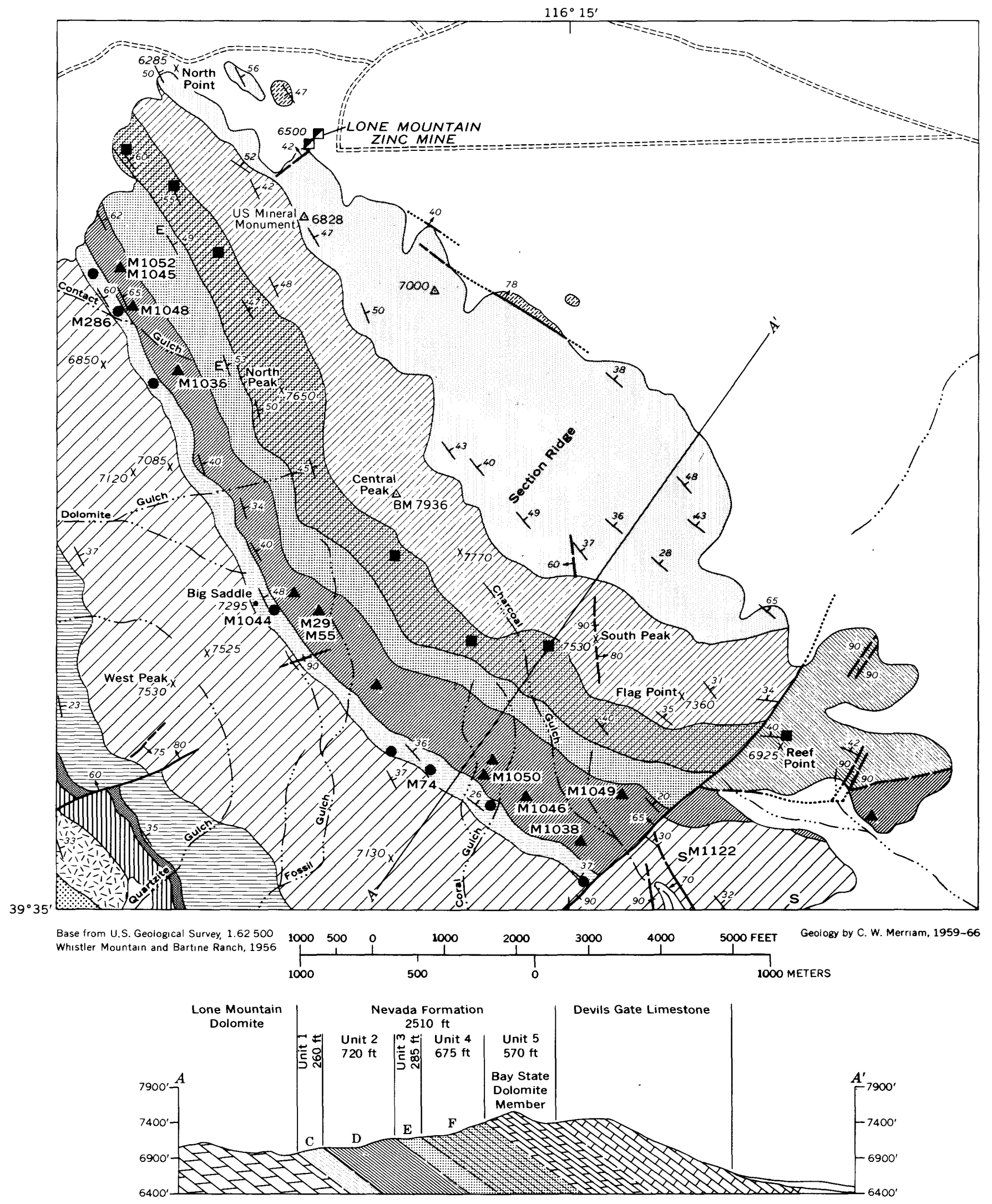

FIGURE 3.-Part of Lone Mountain showing lithologic units in the Nevada Formation of this reference section. Geologic cross section $A-A^{\prime}$, of Lone Mountain reference section. Letters indicate Devonian coral zones. 


\section{EXPLANATION}

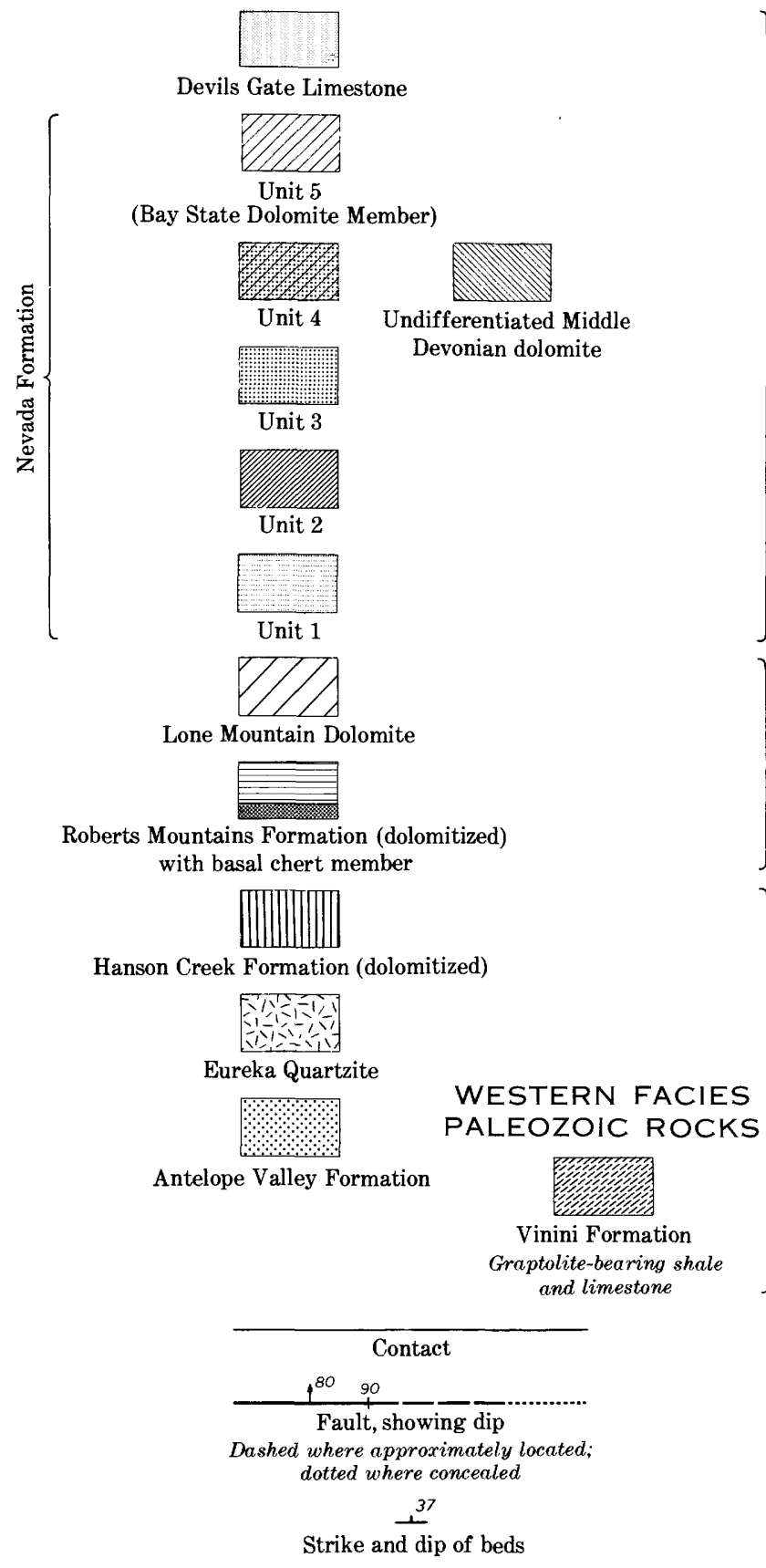

$$
\begin{aligned}
& \text { RUGOSE CORAL LOCALITIES }
\end{aligned}
$$

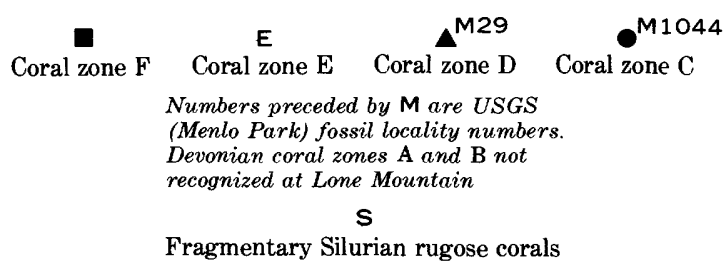

is somewhat intermediate between that of the Diamond Mountains belt and the Antelope-Roberts
Mountains belt. In terms of Lower and lower Middle Devonian stratigraphic paleontology, the Sulphur Spring record is the most complete of the region, comprising coral zones $\mathrm{A}$ through $\mathrm{D}$ in continuous order. At Lone Mountain only zones C and D of this interval were recognized.

\section{BEACON PEAK DOLOMITE MEMBER}

Thick-bedded, rather finely saccharoidal, prevailingly light-gray dolomites of the Beacon Peak Dolomite Member underlie the isolated Twin Hills near Tyrone Gap, and crop out over a broader area at the south end of the range between the Mulligan Gap and Romano faults (fig. 4). Other outcrops occur to the north in the vicinity of Wales Peak and the Prince of Wales mine. Some 400 feet thick, the Beacon Peak of this area passes upward without known break into the arenaceous magnesian limestones and calcarenite at the bottom of Nevada Formation, unit 1. As in its type section in the southern Diamond Mountains at Oxyoke Canyon, the Beacon Peak Dolomite Member of the Sulphur Spring Range contains small lenses of quartzitic sandstone. Here and there it changes toward the top into dolomitic limestone.

Because of geomorphic and structural conditions in gently dipping Silurian and Devonian strata of this range the Lone Mountain Beacon Peak boundary has not been revealed by erosion (fig. 5). However, typical coarsely saccharoidal dolomite of the Silurian Lone Mountain makes up East Ridge on the east side of the Romano fault. In this footwall fault block the Lone Mountain contains abundant Halysites and pycnostylid corals of Silurian age, and may safely be inferred to underlie the Beacon Peak in the west or hanging-wall block of the high-angle Romano fault.

Fossils are scarce in most of the Beacon Peak Dolomite Member of the Sulphur Spring Range, especially at the south end and in the isolated Twin Hills. Scattered deposits of well-preserved silicified corals and brachiopods represent coral zone $\mathrm{A}$ and the Rabbit Hill Helderbergian fauna. Because no identifiable fossils were found in the Beacon Peak Dolomite of the type area in the Diamond Mountains, the correlation is based upon lithologic and stratigraphic criteria.

\section{NeVAda Formation, unIT 1}

Unit 1, which is defined at Lone Mountain, is represented by quite similar strata in the Sulphur Spring Range (fig. 6). At Sulphur Spring Range, however, it includes basal arenaceous magnesian limestones and calcarenite unrecognized at Lone Mountain; these lowermost beds contain in considerable abundance the Costispirifer arenosus brachiopod assemblage of 

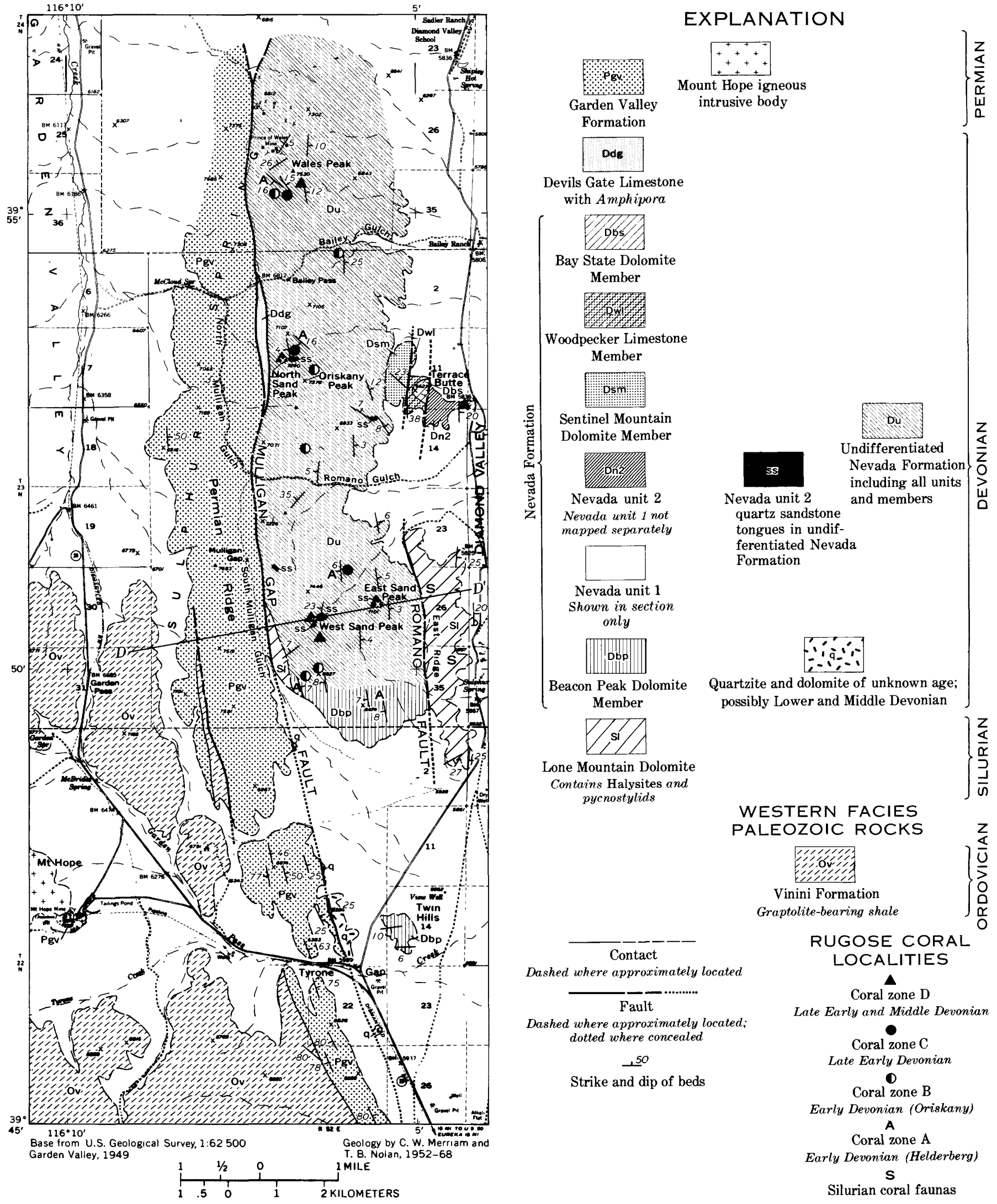

FiguRE 4.-Geologic sketch map showing Silurian and Devonian units in southern Sulphur Spring Range. Symbols indicate Devonian coral zones. See figure 5, geologic cross section $D-D^{\prime}$. 


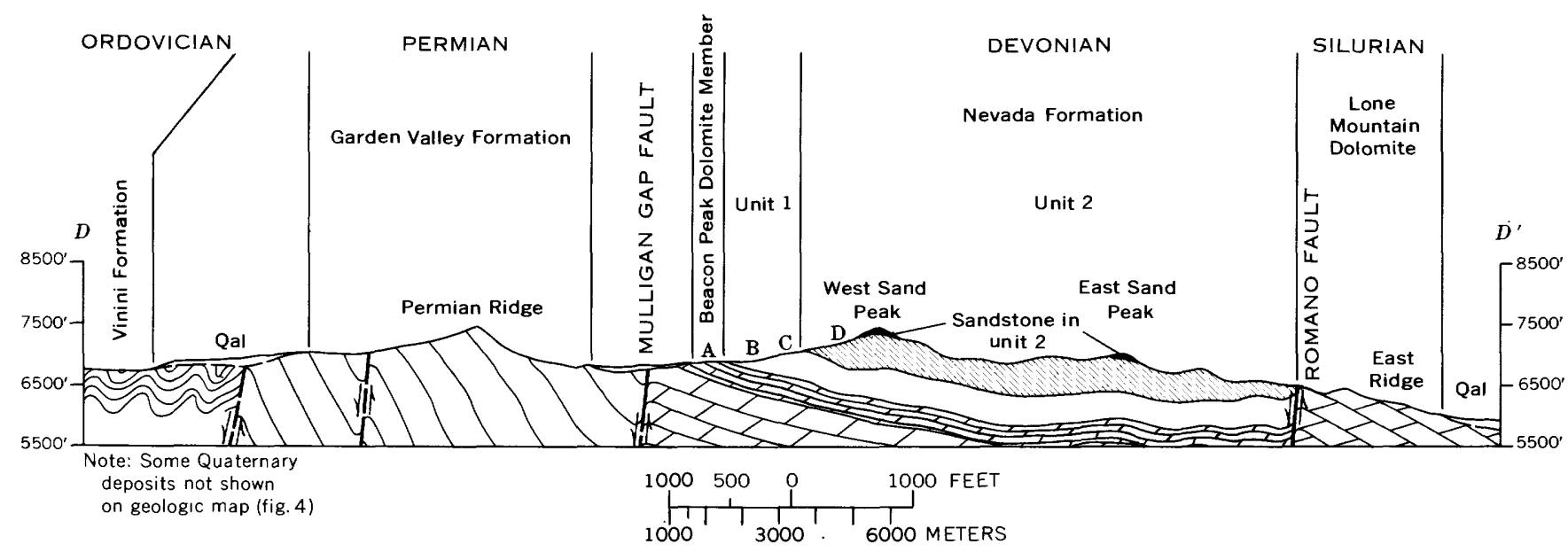

Frgure 5.-Devonian stratigraphic units and coral zones in the southern Sulphur Spring Range.

See figure 4 for location of section.

Oriskany age, together with the large new rugose coral Kobeha which characterizes coral zone B. The basal sandy beds with Costispirifer and Kobeha are exposed at Wales Peak, Oriskany Peak, and Coral Ridge (fig. 4) where they are overlain stratigraphically by higher beds of unit 1 containing the coral zone $\mathrm{C}$ assemblage with Papiliophyllum and Acrospirifer kobehana as in the Lone Mountain section.

\section{NeVAda Formation, unIT 2}

Unit 2 is lithologically and faunally quite similar to the type exposures at Lone Mountain, consisting of argillaceous to silty limestones and siltstones with abundant fossils of coral zone $D$, which everywhere characterize the Antelope-Roberts Mountains facies belt. However, unlike the exposures at Lone Mountain, unit 2 contains in the Sulphur Spring Range numerous tongues and lenses of light-gray to white siliceous sandstone resembling the Oxyoke Canyon Sandstone Member of the Diamond Mountains belt. These sandstone bodies range in thickness from an inch to more than 40 feet. Rounded quartz granules also occur in some of the limestones. Sandstone beds are present throughout unit 2 in this area, but the thicker and laterally more persistent of these siliceous sandstones are in the upper part of the unit. Buttes like North Sand Peak and West Sand Peak (figs. 4, 5) are capped by these resistant sandstones, which are underlain by the fossil-rich argillaceous limestones characteristic of Nevada unit 2.

\section{Sentinel Mountain Dolomite Member}

The approximate stratigraphic equivalent of the Nevada Formation, unit 3 at Lone Mountain, the beds exposed between Oriskany Peak and Terrace Butte (fig. 4) are largely unfossiliferous dolomite. At Lone Mountain, unit 3 is limestone, much of it fine-grained encrinite. Because it has few identifiable fossils, it is referred to as the barren zone. Whereas the gross bedding and textural features of these beds suggest unit 3 at Lone Mountain, the dolomitic nature and especially the alternation of thick light-gray and darkgray dolomite bands is more indicative of typical Sentinel Mountain Dolomite in the Diamond Mountains belt. The stratigraphic relationship to underlying Nevada Formation, unit 2 appears to be normal southeast of Oriskany Peak, but at Terrace Butte the Sentinel Mountain Dolomite is in fault contact with the overlying Woodpecker Limestone Member or Nevada Formation, unit 4.

\section{WOODPECKER LIMESTONE MEMBER}

The limestones of the Woodpecker Member occupy the interval of Nevada Formation, unit 4 at Lone Mountain. However, they are lithologically more like the typical Woodpecker Limestone of the Diamond Mountains and, like the Woodpecker there, yield a brachiopod fauna with abundant Leiorhynchus castanea. The prolific rugose coral assemblages of Nevada Formation, unit 4 and coral zone $\mathrm{F}$ at Lone Mountain are lacking, as is the case also in the typical Woodpecker Limestone Member.

\section{Bay State Dolomite Member}

Thick-bedded light-gray and dark-gray dolomites which form the upper part of Terrace Butte and rest upon the Woodpecker Limestone Member are mapped as the Bay State Dolomite Member. This unit in the Diamond Mountains belt is the equivalent of Nevada Formation, unit 5 at Lone Mountain. Its characteristic 


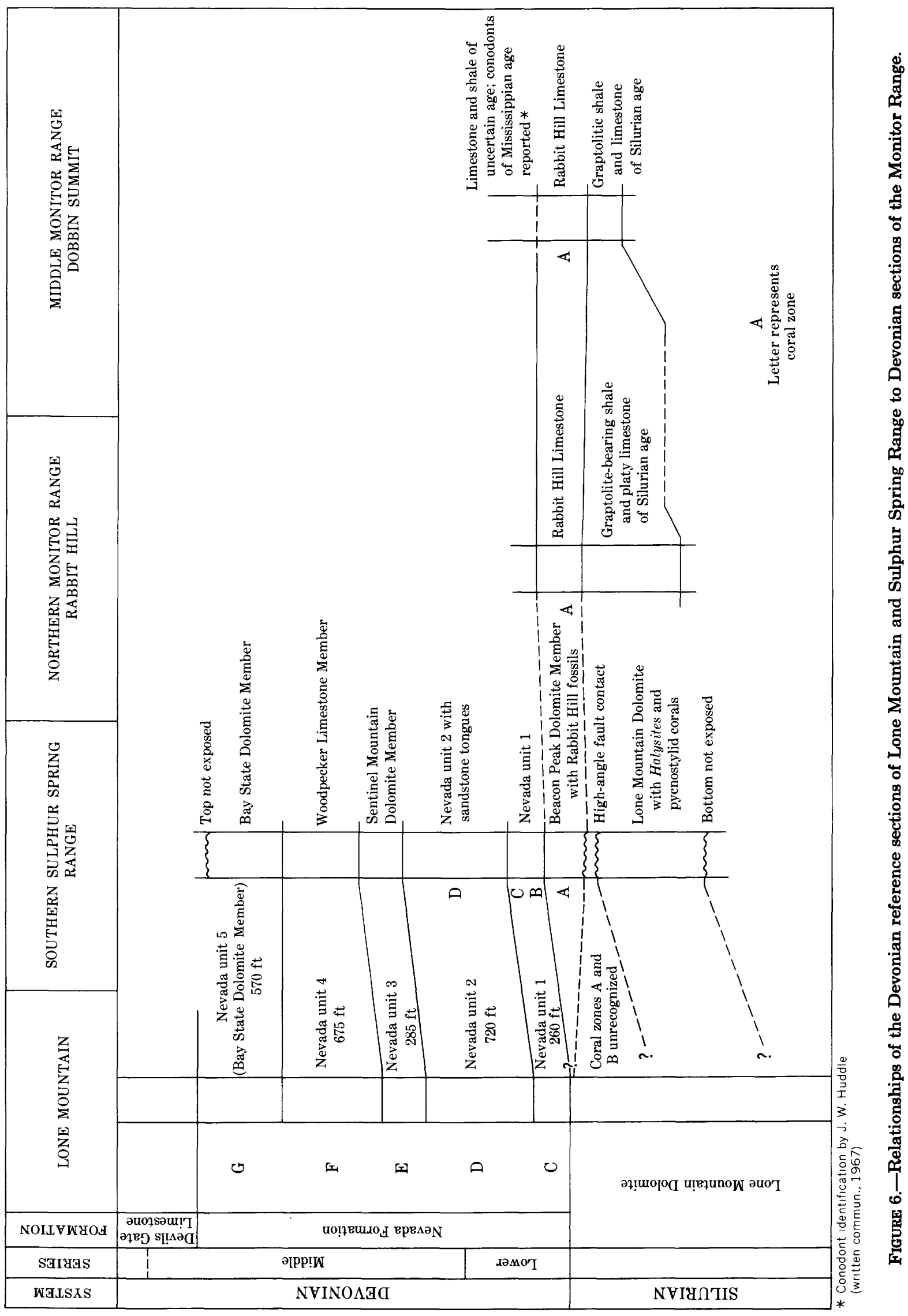


fossil is the large brachiopod Stringocephalus. In the Diamond Mountains, coral zone G brackets the basal beds of the Bay State and the topmost beds of the Woodpecker Limestone Member. No other outcrops of the Bay State were recognized in the southern Sulphur Spring Range.

\section{Devils Gate Limestone}

The Devils Gate Limestone is cut out by faulting in the Terrace Butte vicinity. A fault sliver southwest of Bailey Pass includes the only Devils Gate exposures found in the Southern Sulphur Springs Range. Where present along the Mulligan Gap fault, it lies between conglomerate of the Permian Garden Valley Formation and lower beds of the Nevada Formation, and consists partly of massive stromatoporoid and Amphipora facies.

\section{DIAMOND MOUNTAINS FACIES BELT}

The geographic limits of the easterly Diamond Mountains facies belt (fig. 2) are those of the Diamond Mountains themselves. Between this belt and the Antelope-Roberts Mountains belt to the west, great lithologic and paleontologic changes are observed. Facies changes are most impressive in the lower part of the Devonian column. Within the 20 miles separating Lone Mountain from the Diamond Mountains, the normal Nevada Formation facies of units 1 and 2 disappear and their places are seemingly occupied by dolomite and quartzitic sandstone, with consequent eastward loss of faunas (fig. 7). The possibility of major thrust displacement beneath the intervening Diamond Valley introduces tectonic factors which must be considered in this connection by the structural geologist. The greater part of the eastern Great Basin Devonian is likewise dolomite, and nowhere east of the Diamond Mountains have the lower faunas of Nevada Formation, units 1 and 2 been found thus far. No rugose corals of Early and early Middle Devonian ages are known in the Beacon Peak or Oxyoke Canyon Member of the Diamond Mountains facies belt or, in fact, from Devonian dolomites anywhere to the east within the Great Basin province.

Passing east from the Antelope-Roberts Mountains belt to the Diamond Mountains, the lithologic changes are of lesser magnitude within the upper divisions of the Nevada Formation. However, the faunas of the Woodpecker Limestone Member corresponding to Nevada Formation, unit 4 at Lone Mountain and those of Nevada Formation, unit 5 (which is essentially the Bay State Dolomite Member) reveal significant eastward biofacies changes. For example, the prolific coral assemblages of unit 4 (coral zone F) at Lone Mountain do not appear in the approximately correlative Woodpecker Member of the Diamond Mountains.

\section{Beacon Peak Dolomite Member}

The Beacon Peak Dolomite Member is composed of sparsely fossiliferous fine-textured dolomites with subordinate siliceous sandstone intercalations and lenses which rest disconformably upon more coarsely saccharoidal Lone Mountain Dolomite, according to Nolan, Merriam, and Williams (1959, p. 42). The Beacon Peak Member is in turn conformably overlain by the even more barren Oxyoke Canyon Sandstone Member. Part of the Beacon Peak Dolomite Member, ranging in thickness from 470 feet to about 1,000 feet, is considered to be correlative with the Helderbergian Rabbit Hill Limestone, although its higher beds may be equivalent to arenaceous strata in the lower part of Nevada Formation, unit 1 in the Sulphur Spring Range. Poorly preserved ghosts of large high-spired gastropods are the only fossils known in this member.

\section{OXYOKE CANYON SANDSTONE MEMBER}

The Oxyoke Canyon Sandstone Member consists of thick-bedded quartz sandstone and orthoquartzite with dolomite interbeds; the orthoquartzite resembles white Eureka Quartzite but is less dense and locally has carbonate cement, uncommon in the Eureka. In places the Oxyoke Canyon Member is more than 400 feet thick. Fossils are very uncommon; only at the Phillipsburg mine, 16 miles north of Eureka, were poorly preserved brachiopods found in quartzitic sandstones of this unit. As noted above, the presence of similar quartzitic sandstone as tongues and interbeds within the Nevada Formation, unit 2 rather strongly indicates that the Oxyoke Canyon Member is equivalent to some part of that westerly unit in the AntelopeRoberts Mountains facies belt. Westerly sandstone tongues of Oxyoke character in unit 2 are numerous in the Sulphur Spring Range, at Combs Peak, and at Modoc Peak in the Mahogany Hills, and at Grays Canyon and Eightmile Well in the Fish Creek Range.

\section{SENTINEL MOUNTAIN DOLOMITE MEMBER}

Thick-bedded generally unfossiliferous saccharoidal dolomites of the Sentinel Mountain Dolomite Member exhibit alternation of light-gray and dark-gray dolomite bands to a greater extent than the finer textured Beacon Peak. The Sentinel Mountain Member occupies the approximate interval of Nevada Formation, unit 3 at Lone Mountain, which is limestone, a good part being encrinite. Because of the scarcity of identifiable fossils in both members, they are referred to in paleontologic terms as the barren zone of the Nevada Formation. 


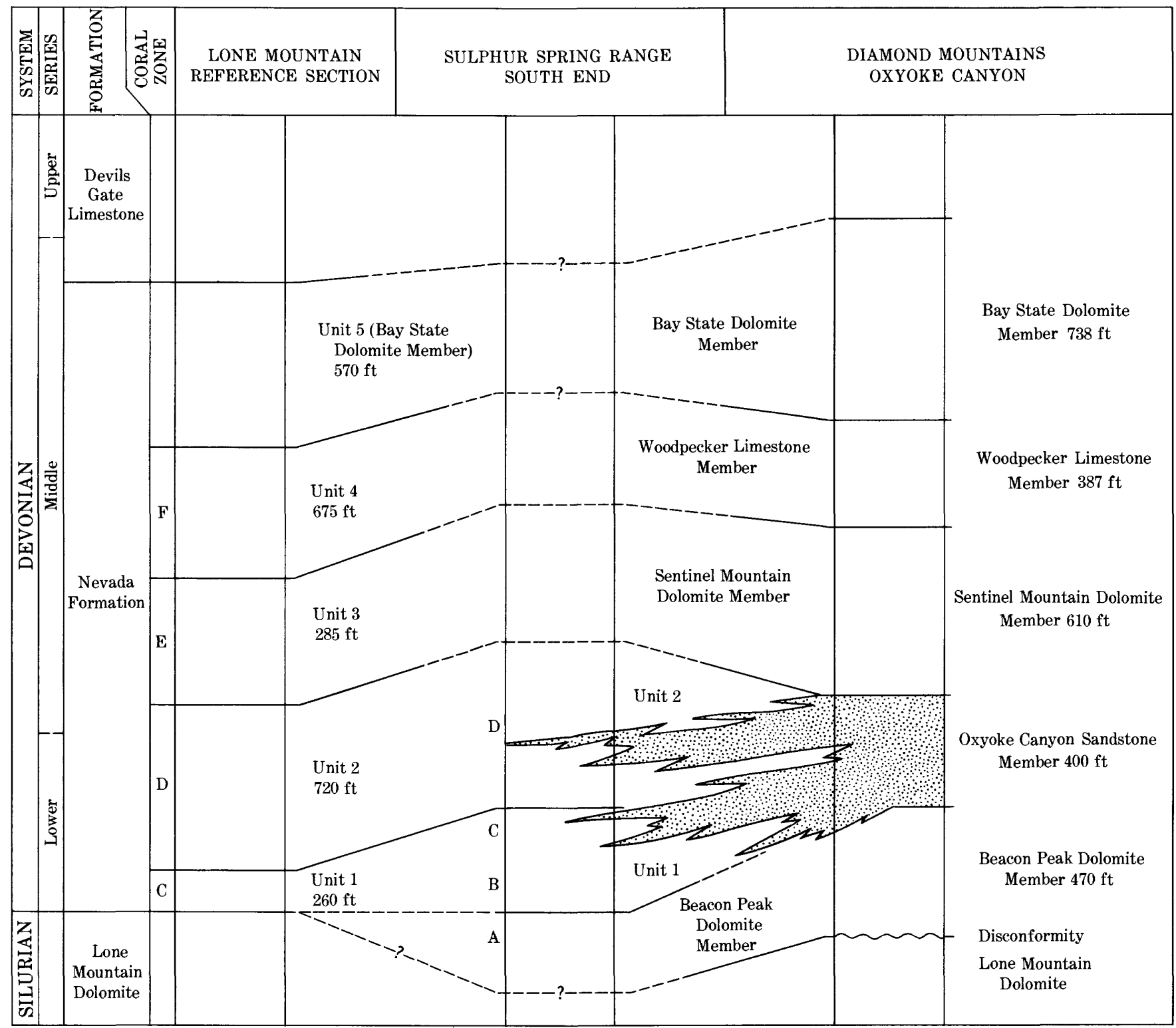

Figure 7.-Relationship of the Devonian reference sections of Lone Mountain and Sulphur Spring Range to that of the Diamond Mountains facies belt at Oxyoke Canyon.

\section{WOODPECKER LIMESTONE MEMBER}

Occupying the interval of Nevada Formation, unit 4 at Lone Mountain, the Woodpecker Limestone Member consists of thin- to medium-bedded limestone and calcareous shale or siltstone, some of which is of slightly pinkish to purplish color. In certain beds, fossils are abundant, especially the brachiopods, of which the most diagnostic is Leiorhynchus castanea. The rich coral assemblages of the dolomitic limestones in Nevada Formation, unit 4 and coral zone $\mathrm{F}$ at Lone Mountain do not occur in the Woodpecker.

\section{BAY STATE DOLOMITE MEMBER}

The uppermost member of the Nevada Formation, the Bay State Dolomite Member, in this belt is thickbedded prevailingly dark gray saccharoidal dolomite. Some beds are loaded with large Stringocephalus shells, other beds contain much favositid coralline material. Rugose corals are common only in the lowermost beds, where they are locally associated with Stringocephalus. Nevada Formation, unit 5 of the Lone Mountain reference section is the approximate equivalent of the Bay State. Great Basin Devonian 
coral zone $\mathrm{G}$ brackets the lowermost strata of the Bay State and the topmost beds of the Woodpecker Limestone Member in the Diamond Mountains facies belt.

\section{DEVILS GATE LIMESTONE}

The Devils Gate Limestone, some 1,200 feet thick, rests conformably upon the Bay State Dolomite Member of the Nevada Formation and is overlain without discordance by the Pilot Shale. As noted under the Lone Mountain reference section, the lower part of the Devils Gate includes much massive stromatoporoid and Amphipora limestone including coral zone $\mathrm{H}$. Thinner bedded upper limestones comprise coral zone I of Late Devonian (Frasnian) age. Coral facies are not well represented in the Diamond Mountains exposures of this limestone.

\section{MONITOR-SIMPSON PARK FACIES BELT}

Lower Devonian limestones of the westerly MonitorSimpson Park facies belt have been traced southward from the Tuscarora and Cortez Mountains (fig. 2) through the Simpson Park, Toquima, and Monitor Ranges to the Dobbin Summit area, a distance of 130 miles. Unlike the two subparallel facies belts on the east, no dolomite is known in either the Devonian or Silurian of the Monitor-Simpson Park belt. Over most of this belt the Helderbergian Rabbit Hill Limestone is the only Devonian unit identified by fossils. Exceptional are outcrops of Nevada Formation, unit 2 (coral zone D) at the north end of the Simpson Park Range near Coal Canyon. Coral-bearing strata of probable Middle Devonian age are known on the west side of the Monitor-Simpson Park belt in the Toiyabe Range south of Austin. This occurrence near Reeds Canyon is the westernmost exposure of Devonian in this region. Underlying strata of possible Early Devonian age at the Reeds Canyon locality have thus far yielded no fossils within the stratigraphic interval just above the Silurian where Rabbit Hill Limestone would be expected.

\section{RABBIT HILL LIMESTONE}

In the type section of the Rabbit Hill Limestone at Copenhagen Canyon, Monitor Range (Merriam, 1963 , p. 42), about 250 feet of continuous section is measurable. The dark-gray limestones and calcareous shales of the type Rabbit Hill are deformed below a thrust and rest without recognized stratigraphic break upon graptolitic deposits of Silurian age. More complete Rabbit Hill sequences occur at Dobbin Summit (fig. 2) and at Coal Canyon, where in each case about 800 feet of the formation is exposed. At Coal Canyon the underlying limestones of Silurian coral zone $\mathrm{E}$ contain a large and diagnostic coral assemblage of Gotlandian character; overlying Nevada beds have yielded faunas of Nevada Formation, unit 2 and coral zone $\mathrm{D}$, but the stratigraphic contact is not exposed. In the Dobbin Summit area, the subjacent Silurian strata have yielded graptolites and brachiopods only. The Rabbit Hill is overlain without recognized discordance by conodont-bearing limestones reported to be of Mississippian age (John W. Huddle, oral commun., 1966). Although no Rabbit Hill Limestone has been found in the adjacent Antelope-Roberts Mountains belt on the east, diagnostic elements of the Rabbit Hill fauna occur in strata assigned to the Beacon Peak Dolomite Member below Nevada Formation, unit 1 of the Sulphur Spring Range.

All the Rabbit Hill Limestone exposures that have been studied represent the Syringaxon facies and Devonian coral zone A. At Dobbin Summit upward faunal changes are, however, observed within this formation. The higher beds contain a large Costispirifer cf. C. arenosus similar to that of lowermost Nevada Formation, unit 1 and coral zone B.

\section{CORAL BIOSTRATIGRAPHY OF THE CENTRAL GREAT BASIN DEVONIAN}

Rugose corals of restricted vertical range make possible biostratigraphic subdivision of the entire Great Basin Devonian into nine successive coral zones labeled by capital letters $A$ through $I$ in stratigraphic order (fig. 8). Four of these time-stratigraphic divisions correspond to mapped rock-stratigraphic units; the remainder occupy rock units with two coral zones or, as in the case of coral zone G, overlap the contact separating two units (fig. 9). Field reference sections, wherein the rocks have been mapped and the stratigraphic section measured, are given for each coral zone.

Value of the proposed biostratigraphic zonation outside the Great Basin province remains to be demonstrated. A possible disadvantage is the use in the zonation scheme of endemic Halliidae like Kobeha and Papiliophyllum, not yet recorded in other provinces. Other families and genera employed are more cosmopolitan, like the Laccophyllidae, Siphonophrentinae, Bethanyphyllidae, Disphyllidae, and the Old World digonophyllids.

Initial biostratigraphic zoning of Great Basin Devonian rocks (Merriam, 1940, p. 9) was based largely on spiriferoid brachiopod ranges; the taxonomy and geologic range of these have recently undergone revision (Johnson, 1966a; 1966b, 1966c). Some earlier adopted brachiopod markers continue to agree with coral indices of the lettered zones. For example, the 


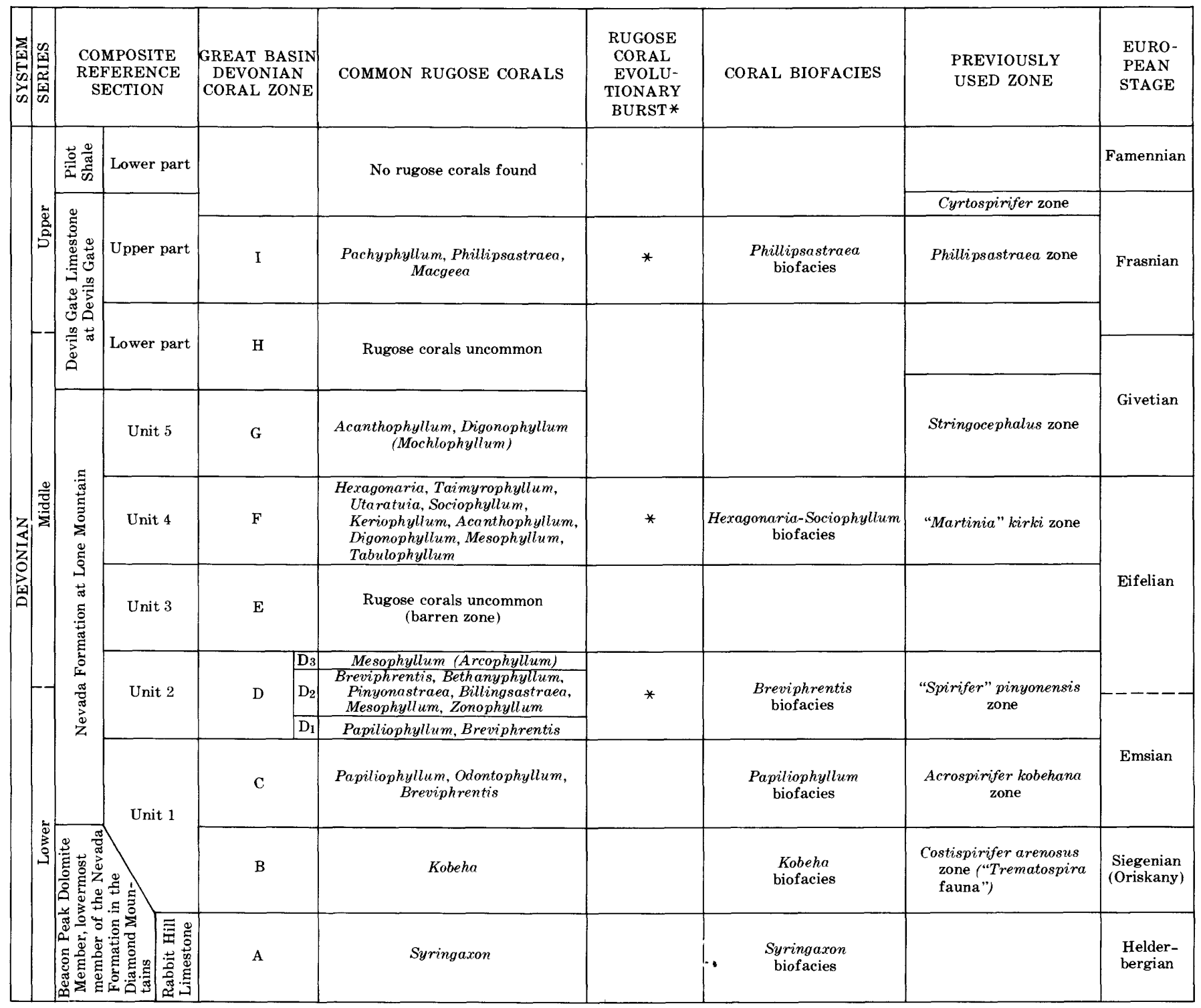

FIGURE 8.-Great Basin Devonian coral zones, equivalent rock units, coral biofacies, and previously employed biostratigraphic designations.

Acrospirifer kobehana zone is coral zone $\mathrm{C}$, and that of Costispirifer arenosus, or the "Trematospira fauna," is coral zone B. The zone of "Spirifer" pinyonensis (now Eurekaspirifer pinyonensis) is essentially coral zone $\mathrm{D}$, although subzone $\mathrm{D}_{3}$ is considered Middle Devonian and may be above the range of this spirifer. In connection with rugose coral study, the associated brachiopods and other diagnostic fossils remain to be more fully evaluated stratigraphically. Tabulate corals, actually the most abundant fossils in certain Great Basin Devonian coral-brachiopod-trilobite beds, are too little understood at present to have definitive stratigraphic value in this province. Cephalopods, other than straight-shelled genera, are uncommon in these rocks. Age and correlation significance of the rare ammonoids collected thus far are discussed below.

The proposed coral sequence is by nature composite, for in no individual section are all nine zones recognized in continuity. Lone Mountain has four in sequence: C, D, E, and F; strata of zones $G$ and $H$ are present, but thus far have yielded no Rugosa at Lone Mountain. For the purposes of this report, the Early and Middle Devonian section in the southern Sulphur Spring Range is the most inclusive; coral zones A, B, C, and D occur here in continuity. Devonian coral zones $\mathrm{G}$ and $\mathrm{H}$ are best represented in the southern Diamond Mountains. Zones $\mathrm{H}$ and $\mathrm{I}$ are recognized in the Devils Gate vicinity, and in the 
adjacent northeastern part of the Mahogany Hills. Late Devonian rocks that include the interval of coral zone $I$ are well exposed in the White Pine mining district, especially along the west margin near the Belmont mine and in the low hills west of Monte Cristo.

Coral zones A, B, and C are of Early Devonian age; coral zone $D$ is Early and early Middle Devonian. Zones E, F, G, and probably the lower half of $\mathrm{H}$ are Middle Devonian. Coral zone I is Late Devonian, including the youngest Devonian rugose corals of this province; none have been found in the high Devils Gate Cyrtospirifer beds, or in the lower Pilot Shale interval that probably correlates with European Famennian.

For convenience, the lettered primary coral zones are further divided by subnumbers as $D_{1}$ and $D_{2}$. In this instance subzone $D_{1}$ has a distinctive rugose coral assemblage regarded as late Early Devonian, whereas that of $D_{2}$ is considered Early or early Middle Devonian; subzone $\mathrm{D}_{3}$ is early Middle Devonian.

In summary, the mapped Devonian rock units containing the zone corals remain to be equated with corresponding biostratigraphic coral range zones. Beginning with the oldest, coral zone $\mathrm{A}$ is typified by the westerly situated Rabbit Hill limestones but is present also in the easterly Beacon Peak Dolomite Member interval of the Sulphur Spring Range, beneath Nevada Formation, unit 1 with coral zones B and $C$ (fig. 9). In the Lone Mountain reference section, only coral zone $\mathrm{C}$ has been identified in Nevada Formation, unit 1 ; coral zones $D, E$, and $F$ of this reference section correspond to Nevada Formation, units 2, 3, and 4 . Coral zone $\mathrm{G}$ is found in a narrow band which brackets the topmost beds of the Woodpecker Limestone Member and the basal beds of the Bay State Dolomite Member (Nevada Formation, unit 5) in the southern Diamond Mountains. Coral zone $\mathrm{H}$ occupies the lower half of the type Devils Gate Limestone wherein the stromatoporoid-Amphipora biofacies is predominant. At Devils Gate, coral zone I is typified by the Phillipsastraea biofacies in the lower part of the uppermost 250 feet of this formation below the Cyrtospirifer beds.

\section{EARLY AND EARLY MIDDLE DEVONIAN CORAL ZONES CORAL ZONE A}

The type section of the Rabbit Hill Limestone in Copenhagen Canyon, northern Monitor Range, is the reference column for this Helderbergian Early Devonian coral zone. Syringaxon foerstei $\mathrm{n}$. sp., index fossil of coral zone A and the Syringaxon biofacies, is common to abundant in a large brachiopod-coral fauna throughout this formation, usually unaccompanied by other Rugosa. Syringaxon as a genus ranges through the Silurian and Devonian; it is represented by many species throughout the world. The genus has been recognized by fragmentary material in the Silurian and Middle Devonian of the Great Basin.

The stratigraphic relationship of the Rabbit Hill Formation and coral zone A to underlying and overlying zones of the Great Basin standard sequence can not be determined at Rabbit Hill, where the subjacent Silurian is a graptolitic facies and no younger Devonian beds are exposed. Therefore elucidation of the true position of these beds depends upon supplementary study of correlative strata in other areas. At Coal Canyon, northern Simpson Peak Range, limestones of the Rabbit Hill rest conformably upon Upper Silurian limestones of the Roberts Mountains Formation and Silurian coral zone $\mathbf{E}$ containing a rich Ludlovian coral fauna of Gotlandian aspect. Upward, however, the boundary with the Nevada Formation is obscure because of faulting and poor exposure. In the Dobbin Summit area of the southern Monitor Range, the Rabbit Hill Limestone is conformably upon Silurian limestone and is overlain with seeming conformity by limestones of uncertain age, dated provisionally by conodonts as Mississippian (J. W. Huddle, oral commun., 1966).

Light is shed upon the true stratigraphic position of the Rabbit Hill fauna and coral zone A as a result of geologic mapping in the southern Sulphur Spring Range. Here dolomite and dolomitic limestone, considered to be a northwesterly extension of the Beacon Peak Dolomite Member, contain Syringaxon foerstei and other elements of the Rabbit Hill fauna. In that area the Silurian Lone Mountain Dolomite is below the Beacon Peak above which lies Nevada Formation, unit 1, whose lowermost beds contain Kobeha walcotti and Costispirifer arenosus of coral zone B. As elsewhere noted, the normal Beacon Peak-Lone Mountain stratigraphic boundary is poorly exposed in the southern Sulphur Spring Range; in the Diamond Mountains it is a disconformity.

In the type section of the Rabbit Hill and coral zone A, Syringaxon foerstei is associated with the tabulate corals Striatopora, Pleurodictyum, and massive Favosites. Distinctive forms among associated brachiopods are Levenea cf. L. subcarinata, Howellella cf. H. cycloptera and new species of Kozlowskiellina, Leptocoelia, and Plethorhyncha. Leonaspis, Proetus, and Phacops are the common trilobites. Large Costispirifer resembling C. arenosus appears in higher Rabbit Hill beds at Dobbin Summit. This early occurrence of Costispirifer foreshadows its presence in coral zone $B$, normally to be expected just above the Rabbit Hill. 
Virtual absence of colonial Rugosa from the known Great Basin Lower Devonian below coral zone D is not easily explainable. Although the faunas of coral zone A normally lack the compound genera, there are two exceptions: the occurrence of Australophyllum landerensis $\mathrm{n} . \mathrm{sp}$. in an otherwise typical Rabbit Hill Syringaxon association of the northern Toquima Range, and a Billingsastraea-like coral in a Rabbit Hill assemblage on Maggie Creek northwest of Carlin, southern Tuscarora Mountains.

\section{CORAL ZONE B}

Reference sections for this Early Devonian coral zone are situated in the southern Sulphur Spring Range, on the ridge 0.5 mile south-southeast of the Prince of Wales mine and at hill 6927, 1.75 miles southsoutheast of Mulligan Gap (fig. 4). Along the main ridge at hill 6927 , the zone $B$ strata are in places loaded with large solitary Rugosa, overlie beds of coral zone $\mathrm{A}$, and are overlain by beds containing the fauna of coral zone $\mathrm{C}$. Zones $\mathrm{B}$ and $\mathrm{C}$ are within the variable dolomitic limestone and limestone of Nevada Formation, unit 1, which rests without break upon the Beacon Peak.

The fauna of coral zone B and the Kobeha biofacies contains Kobeha walcotti, Costispirifer arenosus, and Gypidula cf. G. coeymanensis. The large solitary Kobeha is abundant in beds and pockets, either by itself or with the brachiopods. In places Costispirifer is crowded in layers without the coral. Tabulate corals are uncommon in the coral-rich beds. Other fossils of this zone are a large Strophonella $\mathrm{cf}$. S. punctulifera and the large trilobite Dalmanites. It is significant that the fauna of coral zone B contains but a single rugose coral species and lacks colonial Rugosa.

Another species of Kobeha, here named Kobeha ketophylloides n. sp., occurs in beds low in the Devonian section 1.5 miles north of Roberts Creek Ranch, where it is associated with Gypidula cf. G. coeymanensis, Acrospirifer sp., and Pholidostrophia? sp.

\section{CORAL ZONE C}

The reference section for Early Devonian coraı zone $\mathrm{C}$ is at Contact Gulch on the northwest side of Lone Mountain (fig. 3). A northwest-striking ridge on the north side of this gulch is underlain by Nevada Formation, unit 1, which in this area has changed laterally from dolomite and dolomitic limestone to the limestone here containing fossils of coral zone $\mathrm{C}$. Other excellent exposures of these beds are on the southeast side of Lone Mountain, where Nevada Formation, unit 1 is dolomite which is loaded in places with silicified fossils. Coral zone B was not recognized at Lone Mountain below coral zone $\mathrm{C}$ where it would be expected. In the southern Sulphur Spring Range, coral zone $\mathrm{C}$ occupies the higher beds of Nevada Formation, unit 1 overlying the strata of coral zone B.

The large solitary Papiliophyllum elegantulum replaces Kobeha walcotti of underlying zone B. Associated with Papiliophyllum in this taxonomically more diverse biota are Siphonophrentis (Breviphrentis) kobehensis, Odontophyllum meeki, Aulacophyllum sp. c, and Cystiphylloides lonense. Massive favositids are common. No colonial Rugosa are present. The associated brachiopod fauna is fairly large, including Acrospirifer kobehana, Meristella cf. M. robertsensis, Schuchertella cf. S. nevadaensis, Leptostrophia sp., and a large Cyrtina. This is the fauna of the Acrospirifer kobehana brachiopod zone of previous usage.

The genus Papiliophyllum is not restricted to coral zone $C$; it reappears as an advanced form in coral subzone $D_{1}$, associated with a younger brachiopod fauna.

\section{CORAL ZONE D}

The reference section of coral zone $D$ lies on the west side of Lone Mountain (fig. 3) between West Peak and Central Peak, where it brackets the argillaceous limestones of Nevada Formation, unit 2. Coral zone D corresponds to the "Spirifer" pinyonensis zone of Merriam (1940). The Early and early Middle Devonian coral and associated faunas of this zone are taxonomically the most diverse of the Great Basin Devonian, only those of Nevada Formation, unit 4 and coral zone $\mathrm{F}$ being comparable in this respect. Because of the less compact shaly nature of much of this unit, the abundant fossils weather loose and are easily collected. Hence a large part of the previously described Nevada Formation fauna came from these beds. Coral zone $\mathrm{D}$ includes the lowest colonial Rugosa found thus far in the Nevada Formation.

Using rugose corals, it is feasible to subdivide coral zone $D$ into three subzones, $D_{1}, D_{2}$, and $D_{3}$, in ascending order. Most unit 2 exposures in the main outcrop belt at Lone Mountain yielded $\mathrm{D}_{2}$ collections only. Large collections representing $D_{1}$ came from pediment outcrops 5,500 feet south of Reef Point. Subzone $D_{3}$ collections were made in the higher part of Nevada Formation, unit 2 near the northwest end of Lone Mountain at the head of Contact Gulch.

Subzone $D_{1}$ is characterized by advanced Papiliophyllum elegantulum subsp. $\mathrm{d}$, derived from $P$. elegantulum of coral zone C. Associated large solitary corals are Halliidae of a somewhat different type, probably allied to Papiliophyllum. Among brachiopods are Chonetes macrostriata, Gypidula loweryi, and Strophonella cf. S. pustulosa, together with Leptaena, 
Schuchertella, and Meristella. Spirifers questionably assigned to Eurekaspirifer pinyonensis are uncommon in this assemblage. Chonetes macrostriata is abundant, as it usually the case in lower beds of coral zone $\mathbf{D}$.

Subzone $\mathrm{D}_{2}$ includes among solitary Rugosa: Bethanyphyllum lonense, B. antelopensis, Siphonophrentis (Breviphrentis) invaginatus, Sinospongophyllum spp., Cystiphylloides robertsense, Mesophyllum (Mesophyllum) sp. b, and Zonophyllum haguei. The colonial corals are Disphyllum nevadensis, $D$. eurekaensis, Dendrostella romanensis, Billingsastraea nevadensis, and Hexagonaria (Pinyonastraea) kirki. Associated fossils are those of the "Spirifer" pinyonensis zone, as previously listed by Merriam (1940, p. 54-55) in which the commonest forms are Eurekaspirifer pinyonensis, Atrypa nevadana, Gypidula loweryi, Schizophoria nevadaensis, Schuchertella nevadaensis, Chonetes macrostriata, Dalmanites meeki, and Phacops cf. P. rana.

Subzone $D_{3}$ includes the uppermost beds of Nevada Formation, unit 2 in which the diagnostic coral is the large solitary and structurally complex Mesophyllum (Arcophyllum) kirki. It is doubtful that Eurekaspirifer pinyonensis survived into this early Middle Devonian time-stratigraphic interval, and most of the characteristic fossils of subzone $D_{2}$ have not been collected from subzone $D_{3}$.

\section{MIDDLE MIDDLE DEVONIAN CORAL ZONES}

Profound changes in corals and all other shellbearing marine organisms took place in the interval separating Nevada Formation, unit 2 and coral zone D from Nevada Formation, unit 4 and coral zone F. These changes are not recorded in starta of Nevada Formation, unit 3 , which has yielded few identifiable fossils, hence being referred to as the barren zone. None of the species cross the barren zone, and of five rugose coral genera that survived to coral zone F, three are different subgenerically.

\section{CORAL ZONE E}

Coral zone E occupies the interval of Nevada Formation, unit 3 at Lone Mountain (fig. 3). Crinoid debris in thick beds and lenses makes up a considerable part of the unit. Poorly preserved bushy colonial Rugosa from these beds are assigned questionably to Disphyllum, and scrappy solitary coralla have characteristics of Cyathophyllum.

\section{CORAL ZONE F}

The reference section for coral zone $\mathrm{F}$ is situated on the south side of Lone Mountain, west of Charcoal
Gulch (fig. 3) and is the time-stratigraphic equivalent of Nevada Formation, unit 4. The "Martinia" kirki zone of Merriam (1940) corresponds to this interval. The coral faunas of this zone at Lone Mountain are best represented in dolomitic limestones occupying the upper part of unit. 4

Coral zone $\mathrm{F}$ contains a large, diverse, and potentially reef forming biota including both solitary and colonial genera. The rugose corals of this zone are mostly undescribed, such that generic assignments are for the most part provisional. Among the more abundant genera are: Taimyrophyllum, Hexagonaria, Utaratuia, Sociophyllum, Acanthophyllum, Keriophyllum, Digonophyllum, Mesophyllum (Lekanophyllum), Tabulophyllum, and Crystiphylloides. For the first time in these Devonian rocks, the colonial Rugosa of coral zone $F$ outnumber the solitary forms. Nearly all zone $\mathrm{F}$ species are unrelated to zone $\mathrm{D}$ species; none appear to be ancestral to forms occurring in the higher Devonian coral zones. Several of the diagnostic genera like Taimyrophyllum, Utaratuia, and Sociophyllum are represented also in correlative formations of western Canada.

\section{CORAL ZONE G}

The reference section for coral zone $G$ is situated in the southern Diamond Mountains (fig. 2) at the head of Oxyoke Canyon, west of Sentinel Mountain (Pinto Summit quadrangle). It occupies a 30 -foot interval bracketing the uppermost beds of the Woodpecker Limestone Member of the Nevada formation and the lowermost beds of the overlying Bay State Dolomite Member according to Nolan, Merriam, and Williams, (1956, p. 45). The lowest Bay State beds with Stringocephalus fall within this coral zone, which also contains the genus Rensselandia. Only in this zone are rugose corals known to be associated with Stringocephalus. Characteristic rugose coral genera of coral zone $\mathrm{G}$ are Digonophyllum (Mochlophyllum), Mesophyllum, Acanthophyllum, Cyathophyllum (Moravophyllum), and Cystiphylloides. The colonial Rugosa of coral zone $\mathrm{F}$ at Lone Mountain are not represented in the reference section for coral zone $\mathrm{G}$.

At Lone Mountain the basal beds of Nevada Formation, unit 5, which is approximately correlative with the Bay State, and the topmost beds of Nevada Formation, unit 4, correlative with the Woodpecker Limestone Member, have not yielded the coral zone G assemblage.

\section{LATE MIDDLE AND LATE DEVONIAN CORAL ZONES}

The rugose corals and stratigraphy of the Devils Gate Limestone remain to be studied in detail and, except for generalities, are beyond the scope of this 
report. Earlier investigation of Rugosa from the upper part of this formation by Stumm (1940) and by Merriam (1940) confirmed their Late Devonian age and demonstrated that these higher coral faunas were unrelated genetically to those of the Middle Devonian in coral zones $\mathbf{F}$ and $\mathrm{G}$ of present usage. Above the Stringocephalus zone the interval recorded by thickbedded limestones which make up the lower half of the Devils Gate was seemingly inhospitable to rugose corals, as was the dolomitic Stringocephalus zone in Nevada Formation, unit 5 and the Bay State Dolomite Member. When Rugosa reappear in force just below the uppermost Devils Gate Cyrtospirifer zone, they include newly introduced genera, mostly of a single family not yet discovered in the Great Basin below this horizon. For the Devils Gate time-stratigraphic interval, two coral zones are proposed: coral zone $\mathrm{H}$ below to include the lower coral-poor thick-bedded limestones, and coral zone I above for the upper coralrich beds.

\section{CORAL ZONE H}

Massive stromatoporoids and Amphipora are major rock builders in the interval of coral zone $\mathrm{H}$ and as such have masked and obscured the contributions of other lime-secreting organisms. No Rugosa were found in these beds at Lone Mountain. Rugose corals assigned to Temnophyllum and Disphyllum were collected from the lower 200 feet of the Devils Gate in the southern Diamond Mountains (Merriam, 1963, p. 53). The middle Devonian-Late Devonian transition conceivably falls within the interval of coral zone $\mathrm{H}$.

\section{CORAL ZONE I}

Reference section for Late Devonian coral zone I lies in the Devils Gate Limestone type area on the north side of Devils Gate Pass. The dark-gray coralline limestones below the Cyrtospirifer beds contain the locally abundant Phillipsastraeidae of this zone with only a few solitary Rugosa of other surviving families. Phillipsastraeidae present are the colonial Phillipsastraea, Pachyphyllum, and Phacellophyllum together with the solitary MacGeea.

Other localities where the coral faunas of zone I are represented in the Devils Gate vicinity are on the ridge east of Yahoo Canyon, Whistler Mountain quadrangle. In the White Pine mining district, these faunas occur abundantly near the Belmont mine mill and on the ridge southwest of Monte Cristo, Green Springs quadrangle (Merriam, 1963, p. 54).

Limestones probably equivalent to the lower or Late Devonian part of the Pilot Shale crop out at Devils Gate above the Cyrtospirifer zone; like the Cyrtospirifer beds, these highest Devonian rocks have yielded no Rugosa.

\section{BIOFACIES ASPECTS OF DEVONIAN CORAL DISTRIBUTION AND ZONATION}

Ideally zone fossils may be environmental indicators as well as stratigraphic guides. Patterns of coral distribution in the Great Basin Devonian seaways and their facies belts (fig. 2) give suggestive evidence of environmental control. Rugose coral populations in these seas formed only a part of much larger ecosystems whose spread and survival as a whole were governed by interplay of ecologic factors, physical, chemical, and biologic. Within the same time-stratigraphic interval, entombing sediments of a specific kind may be viewed as criteria of a fairly specific and stable bottom environment where they contain about the same coral biota in widely separated localities. In the section on "Great Basin Devonian Facies Belts and Coral Reference Sections," the broader aspects of rock facies distribution were considered above in connection with physical stratigraphy. There remains the ecologic evaluation of coral zone indicators and their ecologic associates as evidence of a particular biofacies.

From the viewpoint of the biological environment, discontinuous lateral distribution of coral-rich Devonian deposits indicates that optimum ecologic conditions for vigorous coral growth were confined to rather small patches of sea bottom separated by larger areas of scarce shell-bearing benthonic life. Nearly all these coral deposits circumscribed coral loci and thus were not sites of true reef or bioherm building. No biohermal or patch reef complexes of persistent upward growth, with initial sea bottom relief, altered reef cores, and inclined flank beds like those of the Niagaran and the Gotland Silurian were recognized in the Great Basin Devonian. Only in the highest Silurian and in middle Devonian coral zone F do loci of coral proliferation suggest patch reef potential.

Carbonate rocks are generally the favored hosts of rugose corals, especially the colonial forms. Moreover, these Great Basin studies suggest an environmental relationship between abundance and diversity of Rugosa and certain petrologic characteristics of the entombing carbonate. Taxonomically the most diverse Devonian coral faunas of this province occur in the Nevada Formation, unit 2 and coral zone D; the faunas are found in impure nonmagnesian argillaceous limestones with shale and siltstone interbeds. To these varied coral faunas may be compared the more vigorously proliferating coral associations of Nevada Formation, unit 4 (coral zone $\mathrm{F}$ ) which occur in combinations of limestone, dolomitic limestone, and dolomite having a lower percentage of argillaceous matter. Coral faunas of Nevada Formation, unit 4 consist of slightly fewer species, but reveal a greater numerical concentration 
of individuals, especially colonial forms, and are thus more important in rock building. On the contrary, the pure or saturated coarsely saccharoidal Devonian dolomites of this region, as distinguished from unsaturated dolomitic limestones, seem to have been a diagenetic facies singularly inhospitable to Rugosa. Among these are the Sentinel Mountain and Bay State Dolomite Members in the upper part of the Nevada Formation; these have yielded few rugose corals. Rugosa are likewise scarce in diagenetic dolomites making up much of the Devonian System of the eastern Great Basin, that is, east of the Diamond Mountains. Easterly rugose coral scarcity would appear to support these paleoecological observations in the Nevada Formation and suggests that Devonian shelf sea conditions favoring extensive rugose coral growth like that of coral zone $F$ did not prevail in the eastern part of the Great Basin province. To be eliminated in this connection is the factor of possible coral destruction by dolomitic recrystallization. However, in these Cordilleran pure dolomites, where fossils were present in the initial sediments, they commonly escaped destruction locally by early siliceous replacement.

Six biofacies of the Great Basin Devonian (fig. 9) wherein rugose corals are important faunal constituents occur in the following stratigraphic order:

6. Phillipsastraea biofacies of coral zone I

5. Hexagonaria-Sociophyllum biofacies of coral zone $\mathbf{F}$

4. Breviphrentis biofacies of coral zone D

3. Papiliophyllum biofacies of coral zone $\mathrm{C}$

2. Kobeha biofacies of coral zone B

1. Syringaxon biofacies of coral zone A

\section{SYRINGAXON BIOFACIES}

Coral-bearing medium- to dark-gray organic limestones of the Rabbit Hill typify the Syringaxon biofacies and coral zone A. Separated by calcareous shaly intercalations, these limestones commonly include a high percentage of crinoid debris. Thick coarse-textured bioclastic lenses contain the remains of a large brachiopod population, together with tabulate corals of the genera Favosites, Striatopora, and Pleurodictyum and the rugose coral biofacies indicator Syringaxon; this order indicates more or less their decreasing order of abundance. Less numerous are the bryozoans, trilobites, and the Mollusca other than small orthoceratid cephalopods which are rather common. There are no evidences of long transportation of the fossil material; unbroken shells are present in the bioclastic limestones, many brachiopods having articulated valves. Stromatoporoids are a minor constituent. The trilobites Leonaspis and Phacops are locally numerous in platy limestone and calcareous shale interbeds which are a subsidiary biofacies. Throughout the Rabbit Hill limestone the small, solitary Syringaxon is common to abundant in most fossil beds, wherein it is usually the only representative of the Rugosa.

No bioherms or patch reefs were found in the Rabbit Hill Limestone of the Syringaxon biofacies, and the corals had a minor role in rock building. No evidence of dolomitization was recognized in the Rabbit Hill Limestone of this biofacies. Complete silicification of fossils is, however, widespread, a phenomenon which in other formations is commonly associated with or preceded dolomitic replacement. In the Rabbit Hill the process of fossil silicification was clearly selective, affecting brachiopods and corals; hard parts of other organic groups were evidently less susceptible to this kind of silicic additive replacement.

Colonial Rugosa are exceedingly uncommon in the Rabbit Hill and Syringaxon biofacies, there being but two known occurrences: that of Australophyllum landerensis in the Toquima Range and a single Billingsastraea-like form in the southern Tuscarora Mountains of northern Eureka County. Absent are thick-walled solitary rugose coral genera of a possible reef environment like those described from the roughly correlative Coeymans Limestone of New York by Oliver (1960a). Possibly significant environmentally is the small amount of stromatoporoid material in this biofacies, a characteristic also of the Breviphrentis biofacies and coral zone D. Its scarcity may be related to frequent turbidity of the marine waters.

The Syringaxon biofacies is present also in the Beacon Peak Dolomite Member of the Nevada Formation in the Sulphur Spring Range; here the fossils occur in limestone beds which are somewhat dolomitic.

\section{KOBEHA BIOFACIES}

The Kobeha biofacies is in the strictest sense a rugose coral biofacies in which the single species $K$. walcotti predominates. This biofacies is best represented in the lowermost beds of Nevada Formation, unit 1 (coral zone B) in the southern Sulphur Spring Range. Here as at Lone Mountain, unit 1 changes laterally in quite irregular fashion from dolomite to dolomitic limestone to limestone. It is in lenses of calcarenite limestone with many rounded quartz granules that the large solitary Kobeha is most conspicuous and is accompanied by few other fossils. Dolomitic limestones are associated with these coralline facies. In the same stratigraphic interval other calcarenite lenses are loaded with the large shells of Costispirifer of the C. arenosus type. Horn corals and brachiopods appear to have been deposited in situ, but some of the large 
spirifer valves may have been sorted by current action from the heavier corals to be concentrated in separate bands. The corals have been silicified in varying degrees.

\section{PAPILIOPHYLLUM BIOFACIES}

The large solitary Papiliophyllum elegantulum of the Halliidae is the most conspicuous fossil of this biofacies and in coral zone $\mathrm{C}$, which occupies all but the lowermost beds of Nevada Formation, unit 1. At Lone Mountain and in the Sulphur Spring Range, unit 1 is laterally variable, changing in short distances from limestone to dolomitic limestone and to dolomite. Like the Kobeha biofacies and coral zone $\mathrm{B}$ at the base of unit 1, this biofacies lacks colonial Rugosa; however, the fauna as a whole is very much larger. The Halliidae, now at their evolutionary peak, also include Aulacophyllum and Odontophyllum; rugose corals of other families are Cystiphylloides and the earliest Breviphrentis. Favosites in massive heads is the common tabulate. As a whole, the fauna is a mixed association containing many brachiopods, of which the most distinctive is Acrospirifer kobehana. Crinoid debris is abundant. Gastropods and clams are fairly numerous. Papilophyllum succeeds Kobeha, from which it probably evolved, and continues to occupy the same ecologic niche. Within unit 1 there appears to be no special preference of this fauna for either limestone or dolomitic lithofacies. Corals and other fossils are silicified, especially in the more dolomitic carbonate. Relative abundance of stromatoporoids in the cleaner carbonates of this biofacies has not been determined; probably they are numerous and, like the corals, of some rock-building importance. No bioherms or patch reefs were found in beds of the Papiliophyllum biofacies.

\section{BREVIPHRENTIS BIOFACIES}

Following decline of the large Halliidae that characterize the Kobeha and Papiliophyllum biofacies, rugose corals of other families continued to increase in numbers of genera and species. In terms of corals and ecologically associated fossils, the Breviphrentis biofacies of coral zone $\mathrm{D}$ includes the largest and taxonomically most varied faunas of the Great Basin Devonian. The enclosing strata of Nevada Formation, unit 2, to which this biofacies is confined, are impure medium- and dark-gray argillaceous organic limestones separated by shale and siltstone partings and interbeds. Bottom faunas of this stratigraphic interval were subjected periodically to abnormally muddy water resulting from influx of current-transported clay or brought about by storm turbulence. Favositids, solitary Rugosa, brachiopods, trilobites, and Mollusca adapted well to the frequent turbid water episodes. For the first time in the Devonian, colonial Rugosa appear in this biofacies, but these occur sporadically, are rather uncommon, and are far outnumbered by solitary genera. Stromatoporoids are quite scarce. It is suggested that stromatoporoid scarcity and the small population of colonial Rugosa may reflect inability of these organisms to withstand turbidity. In the case of stromatoporoids such a likelihood has been noted elsewhere by Różkowska (1960, p. 7).

Unlike cleaner carbonate rocks of Nevada Formation, unit 1, the impure limestones of unit 2 and the Breviphrentis biofacies were not dolomitized diagenetically. Fossil silicification is, moreover, uncommon, localized, and usually affects only the brachiopods of unit 2. Beds with vast numbers of shells in a mixed coral-brachiopod-trilobite assemblage show minimal breakage of shells by wave or current action. Articulated brachiopod valves are common and favositid heads stand here and there in upright growth positions. The importance of the Rugosa as rock builders is greatly overshadowed by the crinoids, massive favositids, and brachiopods; the stromatoporoids play an insignificant role. No biohermal bodies or incipient patch reefs are known within this biofacies; mixed faunal deposits with corals appear to have accumulated as bands or beds in shallow water without appreciable bottom relief.

Subordinate molluscan biofacies occupy shale or siltstone interbeds of Nevada Formation, unit 2. Clams and large gastropods are abundant locally in these interbeds. Also present are the large heavyshelled benthonic tentaculites. Straight-shelled Orthoceras-like cephalopods are fairly common in the Breviphrentis biofacies, but the nautiloids and goniatites are quite uncommon.

Coralline beds with mixed faunas of the Breviphrentis biofacies are usually dominated by massive favositid heads. Numerically the most abundant Rugosa are Breviphrentis, followed in order by Bethanyphyllum, the cystiphylloids, and the digonophyllids. Compound genera like Billingsastraea, Pinyonastraea, and Disphyllum are widely scattered in relatively small pockets.

More detailed facies analysis of Nevada Formation, unit 2 and the Breviphrentis biofacies will doubtless lead to recognition of additional subsidiary biofacies within which coral, trilobite, and other benthonic associations may be discriminated. Biofacies comparison with the Onondaga Limestone of New York which is approximately correlative geologically is suggested. Unlike the Onondaga, no patch reefs or extensive concentrations of colonial rugose corals were recognized in the Breviphrentis biofacies. Oliver's 
(1968, p. 31) New York Onondaga biofacies studies call attention to five facies ranging in taxonomic coral diversity from a high figure in patch reefs or bioherms to a low figure in bedded coralline deposits. Ecologically and taxonomically significant is Oliver's $(1968$, p. 30) observation that environmental factors permitting high species diversity in Onondaga coral faunas also favored greater variation within the studied species.

\section{HEXAGONARIA-SOCIOPHYLLUM BIOFACIES}

Rugose coral assemblages of this predominantly coralline biofacies in coral zone $F$ occupy dolomitic limestone, limestone, and dolomite of Nevada Formation, unit 4 . The very great difference of coral faunas from those of the Breviphrentis biofacies and coral zone $\mathrm{D}$ is in harmony with the marked lithofacies disparity, and the two are separated stratigraphically by the barren zone of Nevada Formation, unit 3 and coral zone $\mathbf{E}$. For the first time in the Devonian, colonial Rugosa outnumber the solitary forms in most localities. The massive Favosites, so abundant in zone $\mathrm{D}$, is replaced by less numerous digitate favositids and by Heliolites, a tabulate not found in the Devonian below zone F. Patchy, discontinuous dolomitization is similar to that in Nevada Formation, unit 1 and coral zones B and C. Rugose corals and brachiopods of the Hexagonaria-Sociophyllum biofacies are strongly silicified within the dolomitic carbonate. Rugose corals together with stromatoporoids in situ are major carbonate builders in loci of thick-bedded massive and more or less dolomitic limestone. Although this biota is potentially reef forming, no true bioherms of large dimensions were observed. The abundant rugose coral genera in this biofacies at Lone Mountain and in the Roberts Mountains are the colonial Hexagonaria, Taimyrophyllum, Cyathophyllum, Utaratuia, and Sociophyllum together with the solitary genera Cystiphylloides, Mesophyllum, Digonophyllum, and Acanthophyllum.

\section{PHILLIPSASTRAEA BIOFACIES}

The Phillipsastraea biofacies of Late Devonian age occurs in relatively clean medium- to dark-gray limestones in the upper part of the Devils Gate Limestone and coral zone I. These upper beds have not been diagenetically dolomitized, although the lower part of the Devils Gate has been locally dolomitized in very irregular fashion. Scattered concentrations of abundant corals in the Devils Gate area and White Pine district consist mainly of the colonial Phillipsastraeidae in bedded deposits. Stromatoporoids, so abundant in stromatoporoid biofacies of coral zone $\mathrm{H}$ in the lower Devils Gate Limestone, become incon- spicuous in the Phillipsastraea biofacies. The tabulate corals are almost unrepresented. Most of the diagnostic Rugosa of this biofacies are classified in the single family Phillipsastraeidae and include the colonial Pachyphyllum, Phillipsastraea, and Phacellophyllum together with the solitary MacGeea.

At Lone Mountain the upper beds of the Devils Gate Limestone of this biofacies are not exposed above the stromatoporoid-rich limestones in coral zone $\mathrm{H}$. They are present at Devils Gate and southward, but they may best be observed in the White Pine district, especially near the Belmont mine mill and in the low range west of Monte Cristo.

\section{CORAL SUCCESSION AND EVOLUTION AS RELATED TO GEOLOGIC CHANGE AND FAUNAL MIGRATION}

Nearly 4,000 feet of geosynclinal marine strata in the central Great Basin records much of the Devonian Period, enclosing an unusually full succession of rugose corals (fig. 9). Stratigraphically and in terms of coral evolution, this succession is, however, far from complete. Limestone or dolomite layers with abundant corals and other fossils are separated by barren layers of similar rock; between the coral-bearing units are entire members hundreds of feet thick which yield almost no Rugosa. How these paleontologic gaps relate to physical and biologic events of Devonian history in the Great Basin province, and more generally in the Cordilleran belt is a matter of some interest. Worthy of consideration in this context is the possible influence of a normal sea bottom ecologic succession upon a coral biota. More important is the influence of contemporaneous physical geologic change in the surrounding terrane upon the accumulating layered sediments.

Lateral spread and migration of the faunas was influenced or compelled by a combination of such physical and biologic factors. Corals of a particular sedimentary facies were adapted to a sea floor environment which also affected or determined the character of the entombing sediment. As with benthonic marine organisms generally, the intricate fabric of rugose coral evolution entails factors of species spread and migration, adaptation to available ecologic niches, isolation of gene pools, mutation or gene recombination, and above all survival or extinction by natural selection. Classic paleontology sheds little light upon the underlying causative factors of evolution. Although the fossil record is demonstrably incomplete, the study of rugose corals from the more continuous sections of this region makes possible the outlining of the broad evolutionary trends and patterns, especially in the 


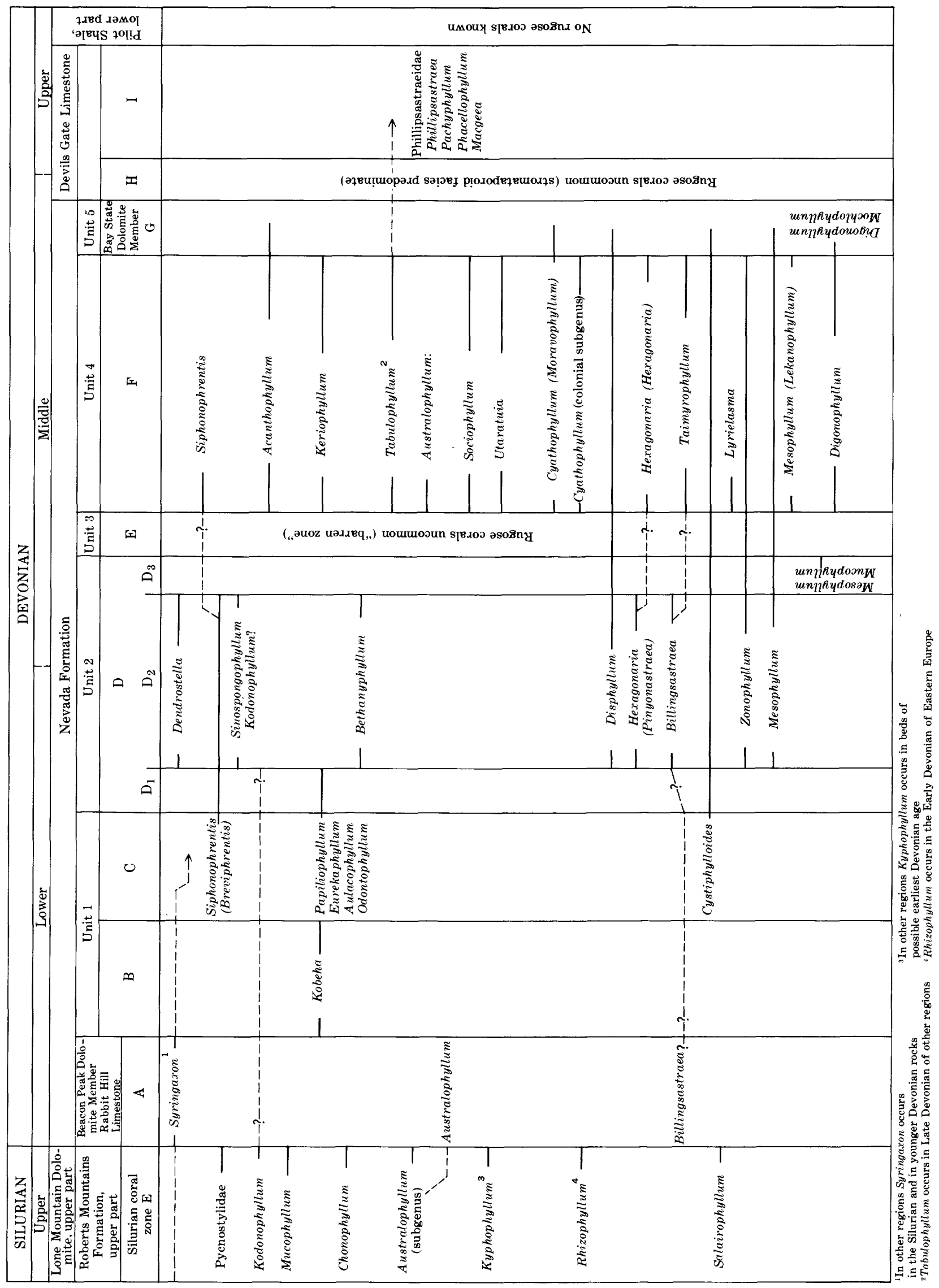


hardier, more persistently adaptive lineages. In basins of fairly continuous carbonate accumulation such as these, coral lineages which survived for long periods of progressive in situ evolutionary change may theoretically be distinguished from less adaptive stocks, the fossil record of which is in this area brief. In the central Great Basin Devonian, persistent lineages of this kind are probably recognizable in the Laccophyllidae with Syringaxon, in the endemic Papiliophyllinae, in the Bethanyphyllidae, and among the Siphonophrentinae, as represented by Breviphrentis. Abundant and ranging through considerable thicknesses of strata, these evolutionary lineages may lend themselves eventually to bed-by-bed quantitative evolutionary investigation.

The physical and biologic environment within a given area of shallow Devonian sea bottom was undergoing constant fluctuating change. As recorded by sediments and their entombed fossils, these changes were to some extent repetitive and perhaps in some instances cyclical. Exclusive of physical geologic factors, the normal ecologic succession of organisms upon a growth site should be considered. Metabolic and secretional activities of ecologically interdependent colony-building organisms are capable of so modifying their habitat as to inhibit continued occupancy by the same biota. Hence upward disappearance of a coral assemblage from a particular bed of in situ growth is explainable. The succession of evolving coral assemblages in Nevada Formation, unit 2 provides good examples of this situation.

Physical geologic changes have acted through geologic time to keep the currents of life moving, indirectly affecting the course of organic evolution. Uplift, subsidence, mountain building, and erosion are primary driving forces of biologic change. Evidences of contemporaneous crustal deformation are difficult to recognize and interpret within the stratified Devonian rocks of the Great Basin. Although there are no indications of contemporaneous folding or tilting, it is clear that upward sedimentary rock changes were in some part controlled by crustal deformation affecting the shelving sea bottoms and the adjacent lands. Crustal movements brought local shifts in marine and atmospheric circulation, changing the direction and load capacity of debris-carrying currents. Landward debris sources were modified to affect the offshore character of accumulating marine deposits.

Convincing field evidences of unconformity within the central Great Basin Devonian System are few indeed, there being no recognized angular stratigraphic discordances, major stratigraphic gaps, or erosion intervals. Nonetheless there are many abrupt vertical lithologic changes in seemingly parallel strata, accompanied by sudden faunal change. It is not, therefore, unlikely that significant disconformities have been overlooked. Within Nevada Formation, unit 2 may be observed many repetitive vertical lithologic changes with concurrent faunal change. In this unit fossil-rich limestones characteristically alternate with silty and argillaceous beds containing a somewhat different fauna. Some of these changes appear to be more or less cyclical and may be partly the result of ecological succession. More extreme rock changes in unit 2 followed local introduction of the white quartzitic sands, bringing a facies usually barren of fossils. Sudden and permanent faunal change accompanied the great rock change at the gradational boundary separating unit 2 from unit 3; at this horizon the rich zone D faunas disappear completely. Less abrupt is the appearance of coral zone $\mathrm{F}$ assemblages above the contact of unit 4 with the barren zone of unit 3 .

\section{CORAL CHANGES AT CLOSE OF SILURIAN}

Resumption of limestone or dolomite deposition in Early Devonian time was accompanied by abrupt and profound change in corals (fig. 9). In the Great Basin province, few rugose corals ancestral to Devonian forms are known from either dolomite or limestone facies of the Late Silurian. Change in the character of carbonate deposition at this systemic boundary is not great in several of the studied sections; physical evidences of disconformity observable on the outcrop are local and have been found thus far only in the dolomite facies.

It is reasonable to link the major paleontologic changes at the Silurian-Devonian boundary with the "Caledonian Revolution," a prolonged series of compressive distubances which deformed Silurian and older rocks in widely separated parts of the Northern Hemisphere. Although angular discordance or indication of Caledonian compressive deformation is unknown in the Great Basin, the mapping of the Silurian-Devonian contact in several areas gives evidence of disconformity. For example, in the Gold Hill mining district of western Utah (Nolan, 1935, p. 18), a disconformity is reported as separating Silurian Laketown Dolomite from Early Devonian Sevy Dolomite; this discordance is also recognized in the Confusion Range (R. K. Hose, written commun., 1958). Similarly, in the Diamond Mountains and in the Mahogany Hills near Eureka, Nev., a mappable disconformity separates Silurian Lone Mountain Dolomite from the Lower Devonian beds, according to Nolan, Merriam, and Williams (1956, p. 38). The disconformity has not been traced laterally to the 
Lone Mountain reference section, where the Silurian dolomite is overlain with seeming concordance by dolomite at the base of Nevada Formation, unit 1. Unrecognized at this boundary zone are beds of the Early Devonian Beacon Peak Dolomite Member, which would be expected here, and the coral faunas of Devonian coral zones A and B. Although the Lone Mountain Dolomite-Nevada Formation boundary appears gradational, the possibility of a depositional gap here has not been entirely eliminated.

The beds in the Lone Mountain Dolomite Silurian facies are characterized by the halysitids, pycnostylid Rugosa, and Entelophyllum; none of these corals reappear in the Devonian. Better understood are boundary faunal changes in limestone facies of the Silurian Roberts Mountains Formation where it is overlain without recognized depositional break by the Early Devonian Rabbit Hill Limestone. For example, in Coal Canyon, northern Simpson Park Mountains, the limestones of Late Silurian coral zone E contain a large Gotlandian type coral assemblage with Mycophyllinae, Kodonophyllidae, Chonophyllidae, Pycnostylidae, Goniophyllidae, and Endophyllidae. The overlying Rabbit Hill has yielded only the solitary Syringaxon in this area. A single occurrence of the endophyllid Australophyllum is known elsewhere in the Rabbit Hill. Clearly the rather unimpressive lithologic change at the Silurian-Devonian boundary is not commensurate with the profound change in the coral fauna.

\section{LATE SILURIAN AND DEVONIAN BURSTS OF RUGOSE CORAL EVOLUTION}

From Late Silurian through Late Devonian time, the history of the Rugosa in the Great Basin seaways was characterized by bursts of proliferation and evolutionary differentiation, separated by intervals during which the Rugosa were restricted in taxonomic diversity or poorly represented. Such bursts of coral activity took place: (1) in Late Silurian coral zone $\mathrm{E}$ of the upper Roberts Mountains limestones (fig. 9); (2) in Early to early Middle Devonian coral zone D of Nevada Formation, unit 2; (3) in Middle Devonian coral zone F of Nevada Formation, unit 4; and (4) in Late Devonian coral zone I of the upper Devils Gate Limestone. Each burst involved taxonomically different coral groups which reached their peak in evolution at that time (see table 1). During the intervals of coral zones $\mathrm{A}$ and $\mathrm{B}$, rugose corals were little differentiated although they were locally numerous; the rugose corals of zone $\mathrm{C}$ were becoming more diverse. Coral zones $\mathrm{E}$ and $\mathrm{H}$ show a poor representation of the Rugosa; the beds carrying coral zone $\mathrm{G}$ are
TABLE 1.-Evolutionary coral bursts in the Great Basin during the Silurian and Devonian Periods

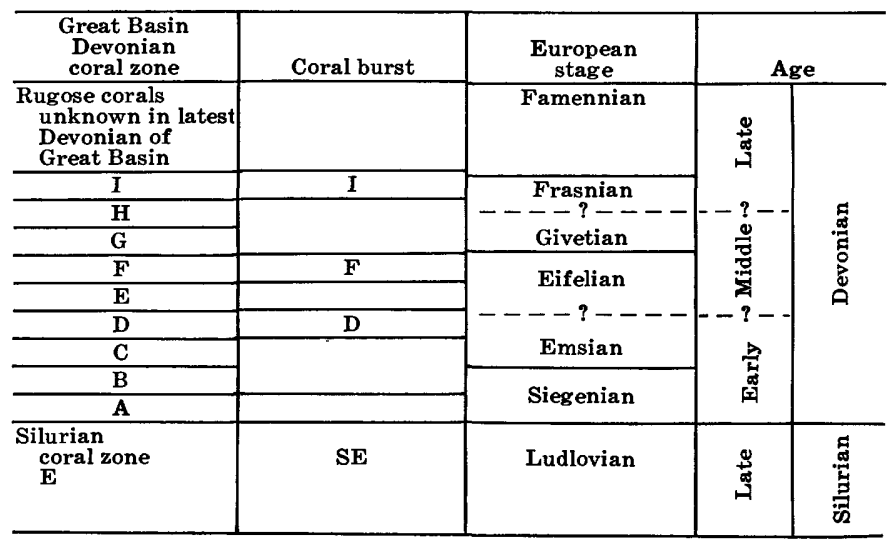

introductory to an interval of dolomite facies unfavorable to the Rugosa.

Following the Late Devonian burst of coral zone I, the Rugosa declined and seemingly disappeared in this region before the close of the Devonian Period. When Rugosa reappear in the Mississippian Joana Limestone following an interval of extinction, they are represented by entirely different families which are unknown below this horizon.

\section{ZONE D CORAL BURST}

With deposition of impure argillaceous limestones in Nevada Formation, unit 2 of the Antelope-Roberts Mountains facies belt came the zone $D$ burst of rugose coral differentiation. This episode opened rather abruptly after the interval of coral zones $\mathrm{B}$ and $\mathrm{C}$ in which solitary Halliidae were dominant and coral faunas were far less diverse. Siphonophrentinae, Cystiphylloidae, and Bethanyphyllidae peaked in coral zone D. Colonial genera, mainly Disphyllidae, appeared, but these are subordinate to the solitary genera. Large solitary Digonophyllidae arrived at this time, reaching their acme later in coral zone $F$, together with the Disphyllidae. Benthonic life was in general favored by the shallow sea environment of zone D; Tabulata were numerous and taxonomically diverse, as were brachiopods, trilobites, and Mollusca. In terms of genera and species, the zone $D$ invertebrate faunas are overall the largest of the Great Basin Devonian.

Except for poorly preserved disphyllids and solitary coral species assigned to Cyathophyllum, the next higher interval of Nevada Formation, unit 3 (coral zone E) yields few Rugosa, and none from coral zone $\mathrm{D}$ are known to carry over into this barren zone.

\section{ZONE F CORAL BURST}

Rugosa again became numerous and taxonomically 
diverse within the interval of Nevada Formation, unit 4. Colonial genera are abundant for the first time in the Devonian, being concentrated in growth sites where corals predominate and where the limestones are partly dolomitic. Away from these dolomitic limestone loci, corals are scarce or absent, as in rocks of this interval in the Diamond Mountains facies belt. Families and subfamilies are not so numerous as in coral zone D, but the Disphyllidae have differentiated generically and the large solitary digonophyllids are at their evolutionary peak. This was also an interval of great rugose coral proliferation through the northern part of the Cordilleran Belt in western Canada.

\section{ZONE I CORAL BURST}

Marine environments in which were deposited the coarsely saccharoidal dolomite and thick-bedded stromatoporoid limestones of zones $\mathrm{G}$ and $\mathrm{H}$ were evidently not conducive to rugose coral growth. When next the Rugosa appear in force within Late Devonian coral zone I, nearly all of the subfamilies and genera of zones $\mathrm{D}$ and $\mathrm{F}$ have disappeared, their places being taken by Phillipsastraeidae and one or two other subordinate families. Ancestry of the Phillipsastraeidae is unknown. In coral zone $\mathrm{F}$ the genus Taimyrophyllum superficially resembles Pachyphyllum, but a study of internal structure does not bear out a genetic connection.

In the upper part of the Devils Gate Limestone, Phillipsastraeidae of zone I occur in scattered concentrations ecologically like those of coral zone $\mathrm{F}$ and do not occupy laterally persistent coral beds. Similar scattered loci of zone I coral proliferation occur in the northern part of the Cordilleran Belt in Canada and Alaska; this family also characterizes the Frasnian of other continents.

\section{AGE AND CORRELATION OF GREAT BASIN EARLY AND EARLY MIDDLE DEVONIAN CORAL ZONES}

Early Devonian rocks were made known in the central Great Basin during the geologic reconnaissance of the Roberts Mountains in 1934. At that time beds containing Costispirifer similar to the eastern Oriskany $C$. arenosus were discovered in a badly faulted section. Stratigraphic studies in the MonitorSimpson Park belt during the 1950's led to the recognition of the Helderbergian age of the Rabbit Hill Limestone (Merriam, 1963, p. 42-44). A review by House (1962, p. 252) of cephalopod evidence in the American Devonian led to the conclusion that the "Spirifer pinyonensis zone" of Merriam (1940, p. 51), initially called Middle Devonian, may also be of Early
Devonian age. In recent years research upon corals and brachiopods allied to a broad program of geologic mapping and stratigraphy in the Sulphur Spring Range and areas adjoining the Eureka mining district has shed light upon age and correlation problems.

\section{AGE AND CORRELATION WITH DISTANT REGIONS}

CORAL ZONE A

The Rabbit Hill rugose coral genera Syringaxon and Australophyllum, because they occur in both Silurian and Devonian strata of distant regions, have at present no definitive correlation value. However, the Helderberg age of this formation is convincingly borne out by associated brachiopods among which are: Levenea cf. L. subcarinata (Hall), Howellella cf. H. cycloptera (Hall), Anastrophia cf. A. verneuili (Hall), and Orthostrophia cf. O. strophomenoides (Hall). Other fossils of Helderbergian affinity are trilobites assigned to Leonaspis and two species of the tabulate coral Pleurodictyum. The closest known relatives of the Rabbit Hill fauna thus occur in rocks of Helderbergian age in New York, Oklahoma, and Tennessee (Merriam, 1963, p. 43). Costispirifer foreshadowing the New York Oriskany $C$. arenosus appears in higher beds of the Rabbit Hill.

\section{CORAL ZONE B}

The large and abundant Kobeha walcotti of the Halliidae occurs here without other rugose coral associates; like Papiliophyllum of succeeding coral zone C, Kobeha seems to be endemic in the Great Basin Province and, as such, is of no distant correlation value at present. Approximate Oriskany or Siegenian age is indicated by the associated brachiopod fauna containing Costispirifer cf. C. arenosus and Gypidula with affinity to G. coeymanensis. The "Trematospira fauna" of Merriam (1940, p. 50), with C. arenosus and Trematospira cooperi, is that of coral zone B. First recognized within the intensely faulted terrane on the west side of Roberts Creek Mountain (Merriam, 1940, p. $50-52, \mathrm{pl} .1$ ), the fossils of this Oriskany interval have in recent years been discovered during the mapping of these deposits southward from the Old Whalen mine area in the Sulphur Spring Range. In this range several of the more complete stratigraphic sections include all Devonian coral zones from A through D in order.

\section{CORAL ZONE C}

The endemic halliid coral Papiliophyllum succeeds Kobeha of underlying coral zone B. A larger coral fauna accompanies Papiliophyllum, including the halliid Odontophyllum meeki and Breviphrentis kobehensis of the subfamily Siphonophrentinae. The Onondaga 
and Hamilton Formations of eastern North America are characterized by members of this subfamily which appears earlier in the New York Coeymans (Oliver, 1960a, p. 87). Siphonophrentis (Breviphrentis) kobehensis is less similar to Siphonophrentis variabilis Oliver of the Coeymans than is Siphonophrentis (Breviphrentis) invaginatus of coral zone D. Eastern species of Odontophyllum (Stumm, 1948b) differ specifically from $O$. meeki of coral zone $\mathrm{C}$ and are reported to be of Middle Devonian age.

A preliminary appraisal of brachiopods in coral zone C, the Acrospirifer kobehana zone (Merriam, 1940, p. 50-53), indicates that a provisional correlation with the European Emsian appears reasonable.

\section{CORAL ZONE D}

Coral zone $\mathrm{D}$ brackets the interval of Nevada Formation, unit 2 in the Lone Mountain reference section and corresponds to the "Spirifer pinyonensis zone" of earlier usage (Merriam, 1940, p. 53). Vertical changes in the rugose corals make it possible to further subdivide this zone into subzones $D_{1}, D_{2}$, and $D_{3}$ in ascending order. Initial appraisal of zone $\mathrm{D}$ coral, brachiopod, and trilobite assemblages by the writer in the 1930's (Merriam, 1940) led to a Middle Devonian age assignment, although underlying strata of coral zone C, or the "Spirifer kobehana zone," were at that time considered Lower Devonian. The beds of Nevada Formation, unit 2 were later assigned by others to Early Devonian (Johnson, 1962a; 1962b; 1966b). Paleontologic support of the Early Devonian interpretation comes in large degree at present from the ammonoid succession as reviewed by House (1962, p. 247-284). A well-preserved goniatite described by A. K. Miller (1938, p. 46, pl. 6, fig. 1) as Agoniatites nevadensis was collected by the writer in 1933 from a locality near M29 on the southwest side of Lone Mountain. The beds yielding the goniatite are Nevada Formation, unit 2, within the range of coral zone $\mathrm{D}_{2}$; associated fossils include Billingsastraea nevadensis. This fossil is the only fairly complete goniatite known from the lower part of the Nevada Formation; fragmentary material has been found at Bush Creek in the Roberts Mountains and at Combs Peak by Walcott. Restudy by House of the Miller type and the only specimen of $A$. nevadensis, in the light of Erben's (1960) revision of European Early Devonian goniatites, led to reassignment of this species to Teicherticeras, a genus considered indicative of the Emsian.

The conclusions of House and of Johnson regarding the Early Devonian assignment of the entire "Spirifer pinyonensis zone" or Nevada Formation, unit 2 are only in part borne out by results of these coral investi- gations. In harmony with an Early Devonian assignment, the coral fauna of subzone $D_{1}$ includes an advanced Papiliophyllum elegantulum called subspecies d. Upward in the section the preponderant Rugosa are Siphonophrentinae of the species Breviphrentis invaginatus, making these faunas similar to the Onondaga faunas. The eastern Onondaga is analogous, as it has an abundance locally of Siphonophrentinae; but the forms belonging to this family are mainly Heterophrentis. Among other Rugosa of subzone $\mathrm{D}_{2}$, Billingsastraea nevadensis shares many features with the late Early Devonian Billingsastraea affinis (Billings) of the Grande Grève, as refigured by Oliver (1964).

Other Rugosa of subzone $\mathbf{D}_{2}$, the Family Bethanyphyllidae, Family Digonophyllidae, and the Hexagonaria, are less in accord with an Early Devonian age; these Rugosa represent elements largely known from starta of Middle Devonian age. The Halliidae, which here characterized the Lower Devonian beds of coral zones $B$ and $C$, are uncommon above subzone $D_{1}$, their places being taken by the Bethanyphyllidae.

Digonophyllidae appear in subzone $\mathrm{D}_{2}$ with Mesophyllum and Zonophyllum. The Digonophyllidae in these beds are greatly outnumbered by Siphonophrentinae and Bethanyphyllidae Zonophyllum haguei is at least specifically distinct from $Z$. duplicatum Wedekind of the early Middle Devonian "Nohner Schichten" in the Eifel district, Germany. In Europe and the Cordilleran Belt of North America, Digonophyllidae, are especially characteristic of the Middle Devonian (Eifelian), peak in Great Basin coral zone F. Bethanyphyllidae in this area are seemingly confined to subzones $D_{1}$ and $D_{2}$. Hexagonaria of subzone $\mathrm{D}_{2}$ is here placed in a new subgenus Pinyonastraea. True Hexagonaria is known here only in coral zone $\mathrm{F}$, where it is locally the abundant genus.

Passing upward at Lone Mountain into subzone $\mathrm{D}_{3}$ and the uppermost beds of Nevada Formation, unit 2 , the Digonophyllidae are represented by the structurally complex Mesophyllum (Arcophyllum) kirki, a species resembling Arcophyllum in the Middle Devonian (Eifelian) in the Eifel district, Germany. Arcophyllum kirki has its nearest relatives in the zone of "Cosmophyllum dachsbergi" at Gerolstein, Eifel district (Wedekind, 1925, p. 71); following Wedekind's interpretation, this horizon is well within the Middle Devonian.

In summary, these data appear to support the ammonoid evidence for the Early Devonian age of some part of the "Spirifer pinyonensis zone" of prior usage, or Nevada Formation, unit 2. However, Middle Devonian rugose coral elements are present in sub- 
zone $\mathrm{D}_{2}$ together with those of latest Early Devonian, and the digonophyllid Mesophyllum (Arcophyllum) kirki of subzone $\mathbf{D}_{3}$ is, in the absence of conflicting data, considered Middle Devonian. Accordingly, the rocks of Nevada Formation, unit 2 and coral zone D are here referred to as Early and early Middle Devonian. Conclusions regarding age and correlation of subzone $\mathrm{D}_{2}$ should await detailed description and analysis of the large brachiopod and trilobite faunas, together with the conodonts and tentaculites of this interval. Likewise the ammonoid evidence is meager at present. Rugose coral data suggest that the subjective Lower-Middle Devonian boundary lies figuratively within a "gray band" of coral zone D and Nevada Formation, unit 2.

\section{CORRELATION WITH OTHER AREAS IN THE CORDILLERAN BELT}

Within the Cordilleran Belt, Early and early Middle Devonian rugose coral-bearing rocks are almost unknown outside the Great Basin. In the Canadian Northwest, the oldest Devonian coral-bearing strata thus far elucidated are the Eifelian or Givetian Hume and Nahanni Formations, which contain faunas correlative with Great Basin coral zone F. Billingsastraealike colonial Rugosa in these Middle Devonian formations are similar to Nevada Formation, unit 4 (coral zone F) species. However, Billingsastraea verrilli (Meek) of the Hume (Pedder, 1964), though specifically distinct, possesses features of the older $B$. nevadensis of coral subzone $\mathrm{D}_{2}$. Strata beneath the Hume have yielded goniatites of the genus Teicherticeras that are indicative of a possible Emsian age (House and Pedder, 1963, p. 491); these older beds are not known to contain Rugosa. The expected distribution of the Devonian System throughout the Cordilleran Belt makes it seem unlikely that strata correlative to Rabbit Hill and Oriskany of Lower Devonian age are absent from these northerly regions. Possibly the strata are represented as relatively unfossiliferous dolomites below the Hume and the Nahanni Formations.

In Alaska Early Devonian rocks are likewise nearly unknown. The well-understood Paleozoic sections of the southeast Alaska panhandle include a very thick Silurian column, and the Middle and Upper Devonian are well represented, but the presence of Early Devonian has not as yet been established.

Of interest in this connection is the occurrence of glacial cobbles in the Chewelah area of Stevens County, northeast Washington, that contain a fauna resembling the Rabbit Hill Helderberg (F. K. Miller, oral commun., 1965). Among the fossils are Syring- axon sp., Pleurodictyum cf. P. lenticularis (Hall), Levenea cf. L. subcarinata (Hall), and a species of Leptocoelia.

\section{NORTH-CENTRAL GREAT BASIN}

NORTHERN SULPHÜR SPRING RANGE

The Nevada Formation extends northward in the Sulphur Spring Range through the Mineral Hill district, where local names have been applied to lithologic subdivisions (Carlisle and others, 1957; Johnson, 1962b). Fossil collections show that Devonian coral zones B, C, and D are present. Zone B strata in McColley Canyon contain a variety of Kobeha differing somewhat from typical $K$. walcotti. West of the Old Whalen mine, lower beds of Nevada Formation, unit 1 carry the Costispirifer arenosus brachiopod assemblage but have not yielded Kobeha; these Costisipirifer beds are calcarenites with quartz grains like those in zone B which contains Kobeha and Costispirifer in the southern Sulphur Spring Range. Beacon Peak Dolomite Member with the Rabbit Hill fauna and coral zone $\mathrm{A}$ has not been identified in the northern part of this range.

\section{SOUTHERN TUSCARORA MOUNTAINS}

The northernmost known occurrence of Lower Devonian beds in the Great Basin is at Maggie Creek, 8 miles northwest of Carlin, Nev. in the southern Tuscarora Mountains. Limestones of Rabbit Hill age at this locality contain a coral-brachiopod fauna including Syringaxon, Pleurodictyum, and a Billingsastraea-like colonial coral. This is one of two occurrences of a colonial rugose coral in Devonian coral zone A. The Helderbergian limestones at Maggie Creek are underlain by the Roberts Mountains Formation.

\section{CORTEZ MOUNTAINS}

In the Cortez Mountains, strata carrying a Rabbit Hill Helderbergian fauna occur 1.5 miles southeast of Mount Tenabo summit (locality M1083). Pleurodictyum together with abundant Syringaxon foerstei indicate Devonian coral zone A.

\section{WEST-CENTRAL GREAT BASIN \\ TOIYABE RANGE}

Devonian limestone and calcareous shale correlative with the Nevada Formation have recently been discovered by R. H. Washburn (written commun., 1968) on the west side of the Toiyabe Range 15 miles southwest of Austin, Nev. (Stewart and McKee, 1968). Exposures in the Reeds Canyon vicinity (locality M1151) have yielded the compound Billingsastraea? 
sp. T and a large Hexagonaria-like form. Provisionally compared to Billingsastraea and Hexagonaria (Pinyonastraea) of coral subzone $\mathrm{D}_{2}$, a restudy suggests that the Billingsastraea-like form may be more closely allied to undescribed Taimyrophyllum of coral zone F. Accordingly, the age of this fauna remains somewhat uncertain, but it is more likely Middle than Early Devonian. As the Toiyabe Devonian section is thick and fairly continuous upward from underlying graptolitic Silurian, it is not improbable that other Devonian fossil horizons, including the Rabbit Hill, may eventually be discriminated here.

\section{SOUTH-CENTRAL GREAT BASIN}

\section{HOT CREEK RANGE}

Corals suggesting zones $\mathrm{C}$ and $\mathrm{D}$ have been collected in little-known Devonian beds of the Hot Creek Range. Fragmentary specimens of probable Papiliophyllum come from locality M1066 in Hot Creek Canyon (H. E. Cook, written commun., 1966) and an Aulacophyllum-like coral comes from the Morey Peak vicinity (H. W. Dodge, Jr., written commun., 1968). Coral faunas of zone $\mathrm{F}$ are better known in this range, suggesting that most or all of the Nevada Formation interval is represented.

\section{SOUTHERN GREAT BASIN}

Southern Great Basin rugose coral-bearing beds of Early and early Middle Devonian ages are known in the Ranger Mountains, the Desert Range, the northern Panamint Mountains, and the Funeral Mountains. The occurrence of faunas at each place indicates a southerly extension of the seaway in which the lower part of the Nevada Formation of central Nevada was deposited. No fossils with certainty as old as the Rabbit Hill Helderbergian have thus far been discovered in these southern mountain ranges.

\section{RANGER MOUNTAINS}

Dolomite, limestone, and quartzite, some 3,000 feet thick and including beds rich in rugose corals, occur in the Ranger Mountains and other ranges bordering Frenchman Flat, Nye and Clark Counties, Nev. (Johnson and Hibbard, 1957, p. 350-356; F. G. Poole, written commun., 1964). A quartzite about 90 feet thick in the lower part of this section probably corresponds to the Oxyoke Canyon Sandstone Member of the Eureka district 200 miles north. The fauna occurring in limestone beds 170 feet below the quartzite and about 10 feet above a thick dolomite sequence includes Siphonophrentis (Breviphrentis) invaginatus, Zonophyllum sp., and Papiliophyllum elegantulum subsp. d. Other fossils identified from this horizon are Chonetes macrostriata, Dalmanites meeki, and a Strophonella. The rugose corals suggest that this fauna represents the lower part of coral zone $D$ and probably correlates with $D_{1}$ of the Lone Mountain column because of the presence of the advanced Papiliophyllum. It is not unlikely that the underlying dolomites include earlier Devonian as well as a Lone Mountain Dolomite equivalent.

\section{DESERT RANGE}

Devonian beds at the south end of the Desert Range, 30 miles east of Frenchman Flat (Locality M1057, C. R. Longwell, oral commun., 1958) include a fauna with Chonetes macrostriata, Strophonella, Acrospirifer sp. and an incomplete corallum of either Siphonophrentis (Breviphrentis) or Sinospongophyllum. This assemblage suggests lower coral zone D, possibly about the horizon of the Ranger Mountains occurrence.

\section{NORTHERN PANAMINT MOUNTAINS}

Fossil collections from the upper part of McAllister's Hidden Valley Dolomite unit 3b (McAllister, 1952, p. 17) in the southern Andy Hills of the Panamint Mountains (Marble Canyon quadrangle, Calif.) include Acrospirifer kobehana, Costispirifer arenosus, Papiliophyllum elegantulum, and Siphonophrentis (Breviphrentis) cf. invaginatus. The spirifers and Papiliophyllum indicate Early Devonian in the combined intervals of coral zones $\mathrm{B}, \mathrm{C}$, and possible $\mathrm{D}_{1}$. The genus Kobeha, which is to be expected with Costispirifer arenosus, was not found here. Possibly C. arenosus ranges upward in the Panamint Mountains into beds with Acrospirifer kobehana and Papiliophyllum. In the lower part of the Nevada Formation of central Nevada, the beds of coral zone B with $C$. arenosus and Kobeha underlie those of coral zone $\mathrm{C}$ with A. kobehana and Papiliophyllum elegantulum. The Panamint beds in question appear to be older than those in the Ranger Mountains and those in the Desert Range that are discussed above which appear to be correlative with the Nevada Formation, unit 2; the Panamint Early Devonian strata are correlative with Nevada Formation, unit 1 of the Lone Mountain section.

\section{FUNERAL MOUNTAINS}

The upper part of the Hidden Valley Dolomite in the vicinity of Pyramid Peak (Ryan quadrangle, Calif.), southern Funeral Mountains, contains coral and brachiopod faunas resembling in part those of the same dolomite unit in the northern Panamint Mountains. Collections from six localities made by J. F. McAllister include an abundance of a large 
Meristella similar to $M$. robertsensis and abundant Siphonophrentis (Breviphrentis) invaginatus. Less common are Papiliophyllum elegantulum and Aulacophyllum-like forms. These collections do not contain Costispirifer arenosus or Acrospirifer kobehana as do collections from the upper Hidden Valley of the Andy Hills area, northern Panamint Mountains. Absence of Early Devonian spirifers suggests that the Funeral Mountains faunas may be somewhat younger than the horizons of coral zones $\mathrm{B}$ and $\mathrm{C}$, possibly being of the age of coral zone $\mathrm{D}_{1}$ which contains the highest Papiliophyllum.

\section{NORTHERN INYO MOUNTAINS}

Upper beds of the Vaughn Gulch Limestone at Mazourka Canyon, northern Inyo Mountains contain a species of Australophyllum similar to A. landerensis of the Rabbit Hill. The upper Vaughn Gulch beds are underlain by strata of Upper Silurian coral zone E that also underlie the Rabbit Hill Limestone at Coal Canyon, Simpson Park Mountains. Confirmation of Helderbergian age of the upper Vaughn Gulch by other fossils has not been achieved, and these beds are presently classified as Late Silurian or Early Devonian.

\section{SYSTEMATIC AND DESCRIPTIVE PALEONTOLOGY}

\section{CLASSIFICATION OF GREAT BASIN EARLY AND EARLY MIDDLE DEVONIAN RUGOSA}

Th classification adopted for Great Basin Rugosa here described is for the greater part in accord with that of Hill (1956), the most comprehensive and authoritative classification published thus far. Departures from Hill's arrangement of families and genera involve content of certain families, status of subfamilies, and family or subfamily assignment of several genera.

A new subfamily, the Siphonophrentinae, is proposed to accommodate certain advanced Streptelasmatidae. Because of uncertainties in the characterization of Zaphrentis, the Family Zaphrentidae is not used herein. The Disphyllidae are considered an independent family not closely related to the Phillipsastraeidae, by reason of fundamental differences of tissue structure. Stumm's subfamily Papiliophyllinae is restored for these seemingly endemic Halliidae; also adopted is Stumm's family Bethanyphyllidae, which has a wide geographic distribution. For certain Great Basin Silurian and Early Devonian species of Australophyllum the Family Endophyllidae is adopted, forms which might otherwise have been relegated to the ill-defined Spongophyllidae. Stumm's Family Cystiphylloidae is restored to include Cystiphylloides, in preference to placing it under Mesophyllum of the Digonophyllidae.

Order RUGOSA Edwards and Haime 1850

I. Family Laccophyllidae Grabau, 1928

Genus Syringaxon Lindström, 1882

Syringaxon foerstei $\mathrm{n}$. sp.

II. Family Streptelasmatidae Nicholson, 1889

(as Streptelasmidae)

Subfamily Siphonophrentinae new subfamily

Genus Siphonophrentis O'Connell, 1914

Subgenus Breviphrentis Stumm, 1949

(as genus)

Siphonophrentis (Breviphrentis)

invaginatus (Stumm)

Siphonophrentis (Breviphrentis)

kobehensis $\mathrm{n}$. sp.

Genus Nevadaphyllum Stumm, 1937

Nevadaphyllum masoni Stumm

III. Family Kodonophyllidae Wedekind, 1927

Subfamily Kodonophyllinae Wedekind, 1927

Genus Kodonophyllum Wedekind, 1927

(?)Kodonophyllum sp. a

IV. Family Stauriidae Edwards and Haime, 1850

Genus Dendrostella Glinski, 1957

(as subgenus of Favistella)

Dendrostella romanensis $\mathrm{n}$. sp.

V. Family Halliidae Chapman, 1893

Subfamily Haliinae Chapman, 1893

Genus Aulacophyllum Edwards and Haime, 1850

Aulacophyllum sp. c

Genus Odontophyllum Simpson, 1900

Odontophyllum meeki n. sp.

Subfamily Papiliophyllinae Stumm, 1949

Genus Papiliophyllum Stumm, 1937

Papiliophyllum elegantulum Stumm

Papiliophyllum elegantulum subsp.

d

Genus Kobeha new genus

Kobeha walcotti n. gen., n. sp.

Kobeha ketophylloides n. gen., n. sp.

Genus Eurekaphyllum Stumm, 1937

Eurekaphyllum breviseptatum

Stumm

VI. Family Bethanyphyllidae Stumm, 1949

Genus Bethanyphyllum Stumm, 1949

Bethanyphyllum lonense (Stumm)

Bethanyphyllum antelopensis $\mathrm{n}$. sp.

Bethanyphyllum sp. d

VII. Family Chonophyllidae Holmes, 1887

Genus Sinospongophyllum Yoh, 1937

Sinospongophyllum sp. d

Sinospongophyllum sp. e 
Sinospongophyllum sp. f

VIII. Family Endophyllidae Torley, 1933

Genus Australophyllum Stumm, 1949

Australophyllum landerensis n. sp.

IX. Family Disphyllidae Hill, 1939

Genus Disphyllum de Fromentel, 1861

Disphyllum nevadense (Stumm)

Disphyllum eurekaensis $\mathbf{n}$. sp.

Genus Hexagonaria Gürich, 1896

Subgenus Pinyonastraea new subgenus

Hexagonaria (Pinyonastraea) kirki (Stumm)

Genus Billingsastraea Grabau, 1917

Billingsastraea nevadensis Stumm

Billingsastraea nevadensis subsp. arachne (Stumm)

Billingsastraea? sp. T

X. Family Cystiphylloidae Stumm, 1949

Genus Cystiphylloides Chapman, 1893

Cystiphylloides robertsense

(Stumm)

Cystiphylloides lonense (Stumm)

Cystiphylloides sp. d

XI. Family Digonophyllidae Wedekind, 1924

Subfamily Digonophyllinae Wedekind, 1924

Genus Mesophyllum Schlüter, 1889

Subgenus Mesophyllum Schlüter, 1889

Mesophyllum (Mesophyllum)

sp. b

Mesophyllum (Mesophyllum)

sp. c

Subgenus Arcophyllum Markov, 1926

(as genus)

Mesophyllum (Arcophyllum)

kirki (Stumm)

Subfamily Zonophyllinae Wedekind, 1924

Genus Zonophyllum Wedekind, 1924

Zonophyllum haguei $\mathrm{n}$. sp.

Zonophyllum sp. a

Zonophyllum sp. b

\section{TAXONOMIC INTERPRETATION OF RUGOSE CORAL STRUCTURE}

Traditional gross comparative morphology of skeletal features is the basis for revised classification of Silurian and Divonian Rugosa here adopted. Diagnostic characters of families and genera are visible to the unaided eye or under low magnification. Coral specialists have long sought recognition of minute histologic details as reliable taxonomic guides. Structures of this kind, visible under a magnification range of 8-20 diameters, have appropriately been called fine structure (Kato, 1963). Although of value in the recognition of certain families, fine structure is somewhat less diagnostic than the well-known minute wall features of fusulinids and orbitoids in Foraminifera. Among Great Basin Silurian and Devonian Rugosa the trabecular groupings are meaningful histologic characters of this scale in wall tissue of Tryplasmatidae and Phillipsastraeidae (Ogilvie, 1897; Hill, 1936; Wang, 1950; Kato, 1963). None of the Early and early Middle Devonian species here described disclose these minute features convincingly. Silicification and other forms of additive chemical change have in most instances destroyed original histologic structures or left them but vaguely discernible in thin section through a veil of secondary crystallization. Ideally a biologic classification based on gross and fine morphology might be supplemented by biochemical analysis of such organic traces as may have survived the fossilization processes.

At species and infraspecies levels, biometrics and statistical analysis of variation have a definite place in coral taxonomy (Oliver, 1968). In some instances statistical techniques may also be of value in the separation of convergent and homeomorphic genera, especially those of rather simple structure. Quantitative studies of this kind always require adequate random sampling of abundant in situ material of undoubted field association. In only a few species are the collections herein described of Early and early Middle Devonian Rugosa adequate at present to justify the quantitative approach. At this stage of Great Basin coral research, taxonomy at the genus level is of prime importance and species discrimination a refinement largely for the future.

The basic solitary rugose coral skeleton is an upsidedown conical platform strengthened internally by horizontal, vertical, and diagonal supports and provided externally with attaching processes. Within the Rugosa generally there are limitless possibilities of taxonomic subdivision using combinations of the more stable megascopic exterior and interior characters. The structural complexity varies from the simple Stauriidae to the very complex interior patterns of the Digonophyllidae.

\section{EXTERIOR CORALLUM FEATURES}

Exterior surface characteristics of the rugosan corallum have been adequately defined by Hill $(1935 ; 1956)$ and require little elaboration in this regard. Among the solitary Devonian taxa here described, surface features of taxonomic value given special attention are: (1) median longitudinal profile of the modified cone, with or without tendency to become elongate-cylindrical at maturity; (2) strength and abundance of rugae; (3) frequency and spacing of rejuvenescence flanges; (4) 
accentuation of septal grooves; and (5) development of connecting or attachment processes.

Among colonial Rugosa generally the exterior features of taxonomic value are growth habit or pattern, which range from loosely fasciculate or bushy to massive cerioid. In the compact cerioid forms, shape and size of the free-growing head are significant, as is the extent of holothecal investment compared to area occupied by the distal or calicular surface. The open bushy forms reveal externally such features as lateral and calice reproductive offsets and lateral connections, which may be tubular as in Pycnostylidae or highly irregular attachment excrescences like those of Entelophyllum.

Some of these gross external characteristics may be viewed as adaptive, or they may be influenced by environmental conditions, as, for example, the external shape of a coral head.

Calice features are part of the corallum exterior, but these also disclose much of the internal structure and the character of reproductive offsets. The individual calice profile in median longitudinal section reveals calice shape and depth; such profiles may be V-shaped, U-shaped, inverted bell-shaped, or squared. Other calice features are: calice pit, median boss, distal calice platform, and reflection of calice rim-all external characters of taxonomic importance. Symmetry of the calice viewed transversely is that of an adult transverse section and shows to advantage the bilateral and quadrilateral features manifested by cardinal, counter, and alar septa. Departures from complete radial symmetry are clearly shown by pinnate arrangements of septa contiguous to a cardinal fossula, present in many genera. Septal edges projecting in from the sides and floor of the calice may be denticulate or entire. The calice rim may be narrow, acute, and unreflected as in Syringaxon or Kobeha; in Mucophyllum, which has a mushroom-shaped corallum, the calice rim is strongly reflected, forming a wide upwardly convex marginal platform. Digonophyllidae that have a wide dissepimentarium also have correspondingly wide calice brims or platforms with a conical median pit.

Compact thamnastraeoid and aphroid colonial genera like Billingsastraea, although lacking a corallite wall, commonly show false surficial walls or raised intercalice polygonal ridges on a calicular surface; other variants of this genus suppress the false wall but develop elevated median cones, as in Pachyphyllum. Such exterior calicinal features do not seem to have more than subgeneric or species value. Characters of the outer corallite wall, septa, biologic symmetry, and reproductive offsets visible in the calice are treated elsewhere.
Some normally solitary Rugosa are closely related genetically to colonial species, calling for taxonomic evaluation of growth habit in this respect. Among normally solitary taxa usually classified as Zaphrentidae, the genus Heliophyllum, as demonstrated by Wells (1937), produces compound adaptive groupings of fasciculate to astraeoid form. Other families which include closely related taxa of solitary to colonial habit are the Tryplasmatidae and the Phillipsastraeidae. Among the last, solitary Macgeea is commonly associated with Phillipsastraea, Pachyphyllum, or Phacellophyllum, and it seems not unlikely this genus is quite polyphyletic, possibly a solitary differentiate, or even a manifestation of dimorphism. Among corals described in this report, there are partly phaceloid individuals of otherwise cerioid Pinyonastraea.

\section{TAXONOMIC EVALUATION OF CORALLUM INTERIOR STRUCTURES}

Chief internal structures of the rugose coral are septa, tabulae, dissepiments, axial structures, and stereoplasmic deposits. The septa and axial structures are vertical elements, the tabulae are horizontal, and the dissepiments are diagonal elements. Complex.patterns consisting of combinations of these elements lend themselves to taxonomic evaluation.

SEPTA

In terms of fine structure, the two principal types of rugosan septa are lamellar and acanthine. Somewhat unsatisfactory attempts have been made (Wang, 1950) to evaluate trabecular patterns of lamellar septa for taxonomic purposes (Kato, 1963). In general these histologic features are too poorly understood and the preservation of most Rugosa unsatisfactory for taxonomic evaluation by this character. No Tryplasmatidae with acanthine trabecular spines were found in the Great Basin Early and Middle Devonian.

Of the eleven families of Great Basin Rugosa here defined, nine possess lamellar septa; the remaining two, Cystiphylloidae and Digonophyllidae, do not have complete and continuous lamellar septa and are dealt with separately.

Septum characters of special systematic importance are: (1) septal count, (2) relative lengths of major and minor septa, (3) vertical continuity of septa, (4) radial continuity of septa, and (5) presence of true septal carinae. Septal thickening by stereoplasm is considered separately.

Evaluation of septal and other interior characteristics at the species level is effectively expressed quantitatively by use of ratios, of which that involving major septum count relative to mature corallite diam- 
eter is the most widely used (Oliver, 1960a, 1968; Rozkowska, 1960).

Within the mature corallum, lamellar septa of most families here defined have a modicum of vertical continuity. Nondissepimented forms like Siphonophrentinae have amplexoid septa which lack this vertical continuity except at the periphery; inward the partial septa extend upward from distal surfaces of tabulae. All genera with lonsdaleioid dissepiments have radially discontinuous septa. This is true also of the Digonophyllidae in which septa tend to lose identity peripherally within a complex mesh. Septal crests or septal spines in these categories are radially alined segments growing toward the axis from inner dissepiment surfaces.

True septal carinae are distinguished by continuity in depth; as seen in longitudinal thin section a carina passes diagonally downward and outward toward the periphery, transacting dissepimental tissue. Carinae are of three kinds: (1) crossbar or yardarm carinae, (2) angulation or elbow carinae, and (3) strip carinae. True carinae are readily distinguishable from minor septal wiggles, unthickened angulations, and stereoplasmic lumps or bumps on septa which do not extend downward from a given transverse plane. Strip carinae are a derivative of crossbar carinae in the outer dissepimentarium of Digonophyllidae like Arcophyllum, wherein the septa are aborted, but the carinae occur as diagonal strips viewed in longitudinal thin section.

\section{TABULAE}

A tabula is a supporting structure that occupies the middle part of a corallum. Tabulae of more primitive Rugosa extend from wall to wall, as in tabulate corals. More advanced dissepimented rugose corals have the interior differentiated into a middle tabularium and an outer dissepimentarium. Tabulae are lamellar, simple, and almost always thin, unlike septa which may be stereoplasmically thickened. In the primitive condition tabulae are nearly straight and horizontal. Modification is by sag or axial inclination; in many advanced genera the tabulae are domed and arched with a peripheral inclination. Tabulae may be entire and complete, or they may comprise short blisterlike domes called tabellae with the appearance of flat dissepiments. Edges of tabellae abut upon other tabellae, on longer more nearly complete tabulae, or against innermost dissepiments.

The boundary separating tabularium from dissepimentarium is discrete in some genera; in other genera the two zones appear to blend. In general the inner dissepiments are steeply inclined axially, whereas the adjacent outer tabellae are inclined peripherally. With genera having an aulos or inner ring, the tabulae may be differentiated into a horizontal axial set and a periaxial set peripherally inclined, as in Syringaxon.

In forms with wide flat tabulae (like Kobeha) the calice floor is a tabula which bends down abruptly at the cardinal fossula.

Spacing of tabulae is rather uniform in some genera; in others there is great irregularity. Sudden change from close spacing to wide may be a response to environmental change. Specimens have been observed among solitary Rugosa in which the abrupt change in attitude of tabulae was obviously a response to the vertically attached corallum having fallen on its side, resulting in a change in growth direction to maintain horizontality of tabulae.

\section{DISSEPIMENTS}

As normal dissepiments, these blisterlike strengthening and space-filling elements occupy interseptal loculi. Lonsdaleioid dissepiments are usually larger, occur in the peripheral zone and are concave toward the outside. A single lonsdaleioid dissepiment opposes the outer ends of several septa. Peripherally the septa never transect lonsdaleioid dissepiments continuously; they occur here only as radially alined crests.

Each normal dissepiment is three dimensionally a spheroid segment with the basal plane axially inclined. Transverse section traces of these dissepiments occur in concentric, axially concave sets between pairs of septa. Peripherally these traces may become anguloconcentric or straight, or they may blend into an irregular herringbone or general cribriform tissue in which the septa are suppressed.

In longitudinal section the overlapping dissepiments form crude columns the number of which has taxonomic meaning. Normal dissepiments may be globose or elongate; lonsdaleioid dissepiments are always elongate and, unlike the normal, dissepiments, are always concave toward the outside, if viewed in transverse section.

Average inclination of dissepiments has taxonomic significance. In solitary and colonial forms with wide corallites, the peripheral dissepiments are horizontal; toward the axis the inclination always increases, such that the innermost, usually smaller, dissepiments stand nearly vertical. A character of considerable systematic value is discreteness or sharpness of the boundary between these inner dissepiments and the tabularium.

Digonophyllid species with complex peripheral patterns may have small nontransverse or radial dissepiments; all the edges of the dissepiments abut on a single septum. 
Dissepiments are generally but not always absent in Ordovician Rugosa and accordingly are viewed as advanced structures in the evolutionary sense. Dissepimented species appear abruptly and in some abundance with the Early Silurian Lykophyllidae and Arachnophyllidae. Nondissepimented Siphonophrentinae are among the abundant forms in the Early and early Middle Devonian rocks of the Great Basin. Dissepiments undoubtedly arose independently in several unrelated rugose coral lineages. With regard to corals with lonsdaleioid dissepiments, this is fairly evident, as they characterize several families among which are the Spongophyllidae, Endophyllidae, Halliidae, and Chonophyllidae. By themselves these lonsdaleioid features are not regarded as indicative of genetic relationship.

Columns of true horseshoe dissepiments are a special category known in the Cordilleran Belt only in Late Devonian Phillipsastraeidae. These features are normally associated with diagnostic trabecular bundles.

\section{STEREOPLASMIC DEPOSITS}

Septa and other primary structures of the rugose coral skeleton are thickened and added to in lamellar fashion by secondary calcareous matter to which the terms stereoplasm or stereome have been given. Within a species certain of these stereoplasmic additions are fairly regular and uniform. Deposits of this kind affect mainly the septa; dissepiments may be so thickened on the inner surfaces, but tabulae are generally not thickened. Axial structures become a solid columella when pervaded by stereome.

Taxonomically the most important stereoplasmic deposits are the fairly uniform peripheral thickenings of septa producing a septal stereozone. Certain genera like Kodonophyllum and Nevadaphyllum always have a wide septal stereozone. Stereoplasmically strengthened columellas do not occur in the Devonian corals here described but are common in late Paleozoic and Silurian genera. Some genera have either a general stereoplasmic dilation of septa throughout their tapered length or a uniform dilation only within the tabularium.

Less significant taxonomically are the minor nonuniform lobose thickenings distributed irregularly along septa or affecting only axial segments. True carinae are not basically stereoplasmic, but may be supplemented by this secondary material. Especially meaningful for systematic purposes are the rather uniform lateral swellings of septa that form an inner stereoplasmic wall or aulos, as in Syringaxon.

Among rugose corals with a well-developed outer wall, the thin epitheca may readily be distinguished texturally in thin section from the contiguous septal stereozone making most of the wall.

\section{RUGOSE CORAL SYMMETRY AND TAXONOMY}

Rugose corals have the underlying bilateral symmetry of the coelenterate. In most genera, however, the more obvious symmetry is radial. In many solitary Rugosa the primary bilateral symmetry is recognizable externally or in the calice by means of the pinnate arrangement of septa with reference to the cardinalcounter plane. Biologic orientation is facilitated in many solitary forms by the adult cardinal fossula enveloping the cardinal septum. Well-defined counter fossulae are less common. In the neanic stage of some species there is a distinct quadripartite pattern defined by cardinal, counter, and alar features; these become less distinct in the ephebic transverse section. Generally the four symmetry quadrants are identifiable in mature growth stages of solitary genera. With reference to the corallum exterior, the cardinal fossula may lie either on the axially concave or the convex side; whether this character is constant within a genus or species is not known.

Contiguous cardinal quadrant septa tend to be pinnate or to become alined at maturity more or less parallel to the cardinal septum and fossula in mature stages. These septal features of symmetry, together with the down-bending of tabulae, define the fossula.

Characters of bilateral symmetry are best shown by solitary Rugosa; most cerioid colonial genera lack a fossula and show little indication of anything but secondary radial symmetry in mature individual corallites.

\section{GROWTH CHANGES AND REPRODUCTIVE FEATURES}

Growth and reproductive features have an important bearing upon rugose coral classification as in all Orders of the Animal Kingdom. Sequences of development change recorded in the corallum have, since the inception of modern coral research, been made use of in this regard. With Early Devonian taxa here described, solitary Papiliophyllinae, when serially sectioned, reveal progressive ontogenetic loss of septal stereoplasmic thickening in more or less orderly fashion. Syringaxon of the Laccophyllidae shows loss of fossulae with development of the mature aulos.

Modes of asexual reproduction or so-called "increase" among Rugosa have been dealt with extensively (Lang and Smith, 1927; Hill, 1935, 1956) and are readily discernible as axial, peripheral, and lateral offsets in solitary and fasciculate taxa (Oliver, 1968, p. 20). Reproductive offsets of compact colonial genera like Hexagonaria and Billingsastraea are difficult to deal with in this respect, calling for selection and special preparation of suitable material. 
Developmental study of colonial genera is intimately related to manner of increase, for not only must ontogenetic changes of corallites be considered, but the colony growth pattern as well. Such patterns are a three-dimensional arrangement of parts contingent upon ways in which reproductive offsets develop from parent corallites (Oliver, 1968; Różkowska, 1960). Few developmental studies of cerioid rugose genera have been carried out. Różkowska's (1960, p. 14-28) Hexagonaria investigations demonstrate calice offsets from the dissepimentarium. Developmental patterns involving reproductive offsets of more conveniently handled phaceloid colonies are touched upon by Oliver $(1968$, p. 26$)$ in connection with statistical variation analyses. In general too little is at present known of these reproductive characters for them to figure significantly in the taxonomy of Devonian compound genera.

Small reproductive offsets, not found in most solitary rugose coral species of the Great Basin Devonian, have been recognized only in a single specimen of Kobeha and in aberrant Breviphrentis. Characteristic of Breviphrentis are rejuvenescence features produced by growth of a single large daughter offset that largely fills the parental calice.

Cone-in-cone growth of solitary Digonophyllidae and Chonophyllidae evidently inspired Wedekind's (1924, p. 21) concept of the "septal cone." In accordance with this view, certain solitary genera with lamellar but vertically discontinuous septa grew upward as stacked-up increments or growth cones secreted by the polyp basal ectoderm during successive growing stages. Septa are represented by radial calice ridges or radially alined septal crests separately secreted after a resting interval.

\section{VARIATION AND DIMORPHISM}

Biometric analyses of individual variation are especially appropriate in connection with rugose coral species discrimination. Studies by Oliver (1960a; 1968) and Różkowska (1960) effectively present these data graphically as ratio curves or scatter diagrams. The most commonly used ratio is that of septal count relative to mature corallite diameter.

Biometry with statistical analysis of data is of value in distinguishing continuous from discontinuous variation and, in connection with possibilities of gene or somatic mutation, dimorphism, and intergrowth within a colonial corallum complex of individuals from two or more protocorallites (Oliver, 1968, p. 24-26). Dimorphism has been suspected but not always convincingly demonstrated in numerous rugose coral species. Appropriate in this regard is reference to the "genomorph concept" of Smith and Lang (1930) which was based upon Carboniferous coral genera in which aberrant corallites or parts of corallites have the appearance of another genus. Critical reviews (Różkowska, 1960; Wilson, 1963; Oliver, 1968) have not encouraged use of genomorph in a taxonomic sense as advocated by its authors. Whereas observations leading to the genomorph idea with reference to Carboniferous Rugosa are valid, the cited examples among Devonian species appear to be founded upon misconceptions, as noted by Różkowska (1960, p. 49).

Likelihood of dimorphism has not been eliminated in connection with certain Devonian species here described, studies of large suites of associated individuals on a population basis will be required. Siphonophrentis (Breviphrentis) invaginatus may bear such a relationship to Nevadaphyllum and to associated individuals with sporadic dissepiments that are questionably assigned to Sinospongophyllum. Among the Disphyllidae, Billingsastraea nevadensis and its subspecies arachne, initially described by Stumm as Radiastraea, would also lend themselves to quantitative appraisal with sufficient material. A similar situation is found in Hexagonaria (Pinyonastraea) kirki, whose range overlaps that of Billingsastraea and which could be interpreted as a genetically related cerioid disphyllid possessing an outer wall.

\section{DESCRIPTIVE TERMS}

Descriptive terms applicable to the structure of the rugose coral have been adequately defined and stabilized by Hill (1935, p. 481-519; 1956, p. F234-F245) and are now widely accepted. New and useful terms have in recent years been proposed by Birenheide, Glinski, Schouppé, and other European coral researchers. Hill's terminology with minor modifications, is adopted in this report.

Family LACCOPHYLLIDAE Grabau, 1928

Reference form.-Syringaxon siluriensis (McCoy) 1850.

Small solitary trochoid to subcylindrical rugose corals with very deep calice, straight smooth lamellar septa, a narrow septal stereozone, and tubular stereoplasmic aulos. Tabulae partly complete, very strongly uparched, nearly flat within aulos, steeply inclined peripherally. No dissepiments.

These nondissepimented but otherwise specialized corals are distinguished by the strong inner ring produced by swelling of septal tips and commonly rather heavy addition of stereoplasm. Arching of tabulae is pronounced. The Laccophyllidae occur in the Silurian and Devonian wherein they may be abundant in a facies with no other Rugosa. Nearly identical small 
corals like Permia, which reappear in the Carboniferous, may be homeomorphic (Hudson, 1944, p. 360; Flügel and Free, 1962, p. 232). Somewhat less convergent are the Permian Polycoeliidae elucidated by Schindewolf (1942, p. 55).

Syringaxon is the only member of this family recognized in the Great Basin, where it is the characterizing rugose coral of the Helderberg Early Devonian Syringaxon facies.

\section{Genus SYRIG GAXON Lindstrom, 1882}

1882. Syringaxon Lindström, p. 20.

1900. Laccophyllum Simpson, p. 201.

1902. Nicholsonia Počta, p. 184. Cited in plate explanations as Alleynia (Nicholsonia).

1928. Laccophyllum Simpson. Grabau, p. 82

1928. Alleynia Počta (Nicholsonia Počta) Grabau, p. 82.

1935. Syringaxon Lindström. Butler, p. 117.

1938. Syringaxon Lindström. (in part). Prantl, p. 21.

1940. Syringaxon Lindström. Lang, Smith, and Thomas, $p$. 129.

1949. Syringaxon Lindström. Stumm, p. 10.

1956. Syringaxon Lindström. Hill, p. F258.

1962. Syringaxon Lindström (in part). Flügel and Free, p. 224.

Type species.-By monotypy, Cyathaxonia siluriensis McCoy, 1850 (p. 281); Silurian, upper Ludlow, Underbarrow, Kendal, Westmorland, England. According to Butler (1935, p. 118) and Lang, Smith, and 'Thomas (1940, p. 129), Lindström, in naming the genus, gave no diagnosis; he merely used McCoy's species siluriensis under the new generic name Syringaxon in his faunal lists of the Gotland Silurian (Lindström, 1882, p. 20).

Diagnosis.-Small, solitary turbinate and ceratoid to cylindrical rugose corals with deep calice and no dissepiments. Axial ends of major septa dilated and laterally in contact to form an aulos. Tabulae strongly uparched distally, the aulos dividing them into inner flat or slightly sagging segments and outer segments which descend steeply to meet the outer wall (Flügel and Free, 1962, fig. 3); tabulae either continuous from wall to wall through aulos stereozone, terminating within the aulos, or abutting proximally as tabellae against adjacent tabulae. Stereome usually abundant as aulos thickening and general thickening or filling in brephic and neanic growth stages. Narrow fossulae commonly reveal quadrants in late neanic growth stages.

Remarks.-Simpson (1900, p. 201) called attention to this distinctive rugose coral group in the American Silurian upon proposal of Laccophyllum, with $L$. acuminatum Simpson from the Niagaran of Perry County, Tenn., as type species. Butler's exhaustive study (1935) determines that McCoy's (1850, p. 281) "Cyathaxonia siluriensis" is the type species of
Syringaxon Lindström; later Lang, Smith, and Thomas (1940, p. 129) concluded that the holotype of Laccophyllum acuminatum Simpson is correctly assignable to Syringaxon, thus making Laccophyllum Simpson a synonym of Syringaxon Lindström.

Alleynia Počta or Alleynia (Nicholsonia) Počta (see Lang and others, 1940, p. 15, 129) appears to be correctly regarded as a synonym of Syringaxon.

Barrandeophyllum Počta (1902, p. 190) is similar to Syringaxon. According to Prantl (1938, p. 34), who studied Počta's cotypes of the type species, Barrandeophyllum perplexum, this genus is virtually identical in habit, form, and general structure with Syringaxon, from which it may have been derived. Barrandeophyllum is distinguished from Syringaxon by irregularities of the aulos, which is usually elliptical in section, and by a sparing development of dissepiments. Stereoplasm is always present but is not abundant. The type species of Barrandeophyllum is reported from the Lower Devonian Branik Limestone of Bohemia. Syringaxon ranges from the Niagaran of Tennessee through strata of Lower Devonian Helderberg age in western North America and is reported in the Upper Devonian Independence Shale of Iowa (Stainbrook, 1946, p. 402).

As noted by Hudson (1944, p. 360), other small and rather simple corals closely resembling Syringaxon range into the Carboniferous, where they are represented by the genus Permia Stuckenberg. According to Hudson, Permia and Syringaxon are probable homeomorphs.

In the Great Basin small solitary corals similar to Syringaxon occur in the lower or Silurian part of the Hidden Valley Dolomite of the northern Panamint Mountains (McAllister, 1952, p. 15-17). Following the great proliferation in the Great Basin Helderbergian these corals seemingly almost disappeared from this region, although scarce and fragmentary specimens which may belong either in Syringaxon or Barrandeophyllum have been found at Lone Mountain in the Nevada Formation, unit 2.

Springaxon foerstei n. sp.

Plate 1, figures 1-16

1963. Syringaxon acuminatum (Simpson). Merriam, p. 43.

Type material.-Holotype, USNM 159243; figured paratypes, USNM 159245-159250 inclusive. Rabbit Hill Limestone, Early Devonian, Central Great Basin; Monitor Range, Nev.

Diagnosis.-Syringaxon has a very deep calice, thick wall, prominent longitudinal grooves externally and on interior of calice wall, and a high septal count for this genus. Cardinal and alar septa are differentiated in neanic stages. 
External features.-Corallum, large for the genus, attains a length of $30 \mathrm{~mm}$ and maximal diameter of $27 \mathrm{~mm}$ at edge of calice; average length about $19 \mathrm{~mm}$ and average diameter $16 \mathrm{~mm}$. Calice very deep, in large individuals as much as $\mathbf{1 6} \mathrm{mm}$ or more than half the corallum length. Average specimen is trochoid, but ceratoid individuals are fairly common; turbinate and nearly cylindrical individuals are uncommon. Septal grooves are sharply defined and distinctly pinnate with reference to the primary septa. Rugae are weakly defined or absent, rarely prominent. A few individuals have talons or attachment surface at apex. Septa extend distally as low subequal ridges on inside of calice and rarely become obsolete. Aulos is defined as a ring-shaped boss at the bottom of the calice in many specimens; in the others the aulos is ill defined, and narrow fossulae may outline quadrants made by the primary septa.

Transverse sections.-Mature sections have 26 to more than 30 major septa extending three-fourths of the distance to the axis. Minor septa are normally present, but in some individuals are not recognizable at maturity; these septa range from mere stubs to one-third the length of the major septa; in some specimens the septa are buried within the peripheral stereoplasm. Septa are usually dilated toward tips, laterally in contact, and reinforced by stereoplasm to produce an aulos. Entire septum may be somewhat dilated. Individuals that have a poorly defined aulos have pairs of contiguous septa meeting axially like a tuning fork, and merged segments continue toward axis; some of these specimens reveal quadrate transverse symmetry. The thickness of the peripheral stereozone in some specimens exceeds $1 \mathrm{~mm}$, but is usually not so thick as the aulos. There is considerable variation in the amount of stereoplasm; some early ephebic sections show the entire aulos filled with this material. The appearance of false dissepiments possibly results from section-cutting bulbous distal inflations of tabulae between the aulos and the outer wall.

Longitudinal sections.-Outer segments of tabulae descend steeply, with upward inflection before meeting the stereozone. Some complete tabulae are vague within the aulos, others are traceable com- pletely across. Some aulos segments of tabulae may be thickened stereoplasmically. Some specimens have complete tabulae with M-shaped curvature and nearvertical outer segments. Tabular spacing is nonuniform and usually is fairly wide.

Comparison with related forms.-Butler's (1935) figures of Syringaxon siluriensis (McCoy) show a maturely cerioid to subcylindrical form with fewer septa and poorly developed minor septa. Syringaxon foerstei includes externally similar subcylindrical variants, but the norm is a trochoid corallum. Both tend to have heavy stereoplasmic deposits in the aulos and a wide septal stereozone. Of several species figured by Prantl (1938) from the Devonian of Czechoslovakia, most have a lower septal count and elongate subcylindrical coralla. Species described from the Greifensteiner Kalk (Eifelian) of Germany by Flügel and Free (1962) have a weaker aulos and less arching of tabulae.

Occurrence.-Rabbit Hill Limestone of Helderberg Early Devonian age; Devonian coral zone A. Northern Monitor Range, Rabbit Hill vicinity: localities M48, M49, M187. Middle part of the Monitor Range, Dobbin Summit area: localities M1067, M1068, M1069. Northern Simpson Park Mountains, Walti Hot Springs area: locality M1074; Coal Canyon area: localities M1032, M1075, M1076. Cortez Mountains, Mount Tenabo area: locality M1083.

Beacon Peak Dolomite Member (Helderberg Early Devonian age) of the Nevada Formation; Devonian coral zone A. Southern Sulphur Spring Range: localities M186, M197, M1081, M1082.

\section{Family STREPTELASMATIDAE Nicholson, 1889 (as STREPTELASMIDAE)}

Reference form. - Streptelasma corniculum Hall. Ordovician, New York.

These are solitary rugose corals with or without fossula, normally without dissepiments but with a discrete septal stereozone; tabulae are wide, flat or domed, some complete. Septa of primitive forms are thickened and laterally in contact through mid-neanic stage; septa thin peripherally from axis; in some genera septa reach axis and form with domed tabulae axial complexes or columellae. Tabulae, obscure in this genera, have a very wide stereozone.

Measurements of Syringaxon foerstei $n$. sp.

\begin{tabular}{|c|c|c|c|c|c|c|}
\hline \multirow[b]{2}{*}{$\begin{array}{l}\text { USNM } \\
\text { No. }\end{array}$} & \multirow[b]{2}{*}{$\begin{array}{l}\text { Corallum length } \\
\text { restored }(\mathrm{mm})\end{array}$} & \multirow[b]{2}{*}{$\begin{array}{c}\text { Calice depth } \\
(\mathrm{mm})\end{array}$} & \multicolumn{2}{|c|}{ Calice bottom } & \multicolumn{2}{|c|}{ Ephebic section } \\
\hline & & & $\begin{array}{l}\text { Outside diameter } \\
(\mathrm{mm})\end{array}$ & $\begin{array}{l}\text { Number of } \\
\text { major septa }\end{array}$ & $\underset{(\mathrm{mm})}{\text { Dianeter }}$ & $\begin{array}{l}\text { Number of } \\
\text { major septa }\end{array}$ \\
\hline $\begin{array}{l}159243 \text { (holotype) } . . . . . . . . . . . . . \\
159244 \text { (paratype) .............. } \\
159246 \text { (paratype) ............. } \\
159248 \text { (paratype) } \ldots . . . . . . . . \\
159352 \text { (pl. } 1 \text {, figs. } 9,10 \text { ) .... }\end{array}$ & $\begin{array}{l}32 \\
17 \\
- \\
-\end{array}$ & $\begin{array}{r}16 \\
8 \\
- \\
-\end{array}$ & $\begin{array}{l}12 \\
11.5 \\
-\end{array}$ & $\begin{array}{l}28 \\
24 \\
- \\
-\end{array}$ & $\begin{array}{l}- \\
9.5 \\
13 \\
15.6\end{array}$ & $\begin{array}{l}- \\
\overline{26} \\
24 \\
26\end{array}$ \\
\hline
\end{tabular}


This diverse long-ranging family will probably lend itself to further subfamily taxonomic subdivision eventually. Great Basin Devonian representatives are classified in a new subfamily, here designated as the Siphonophrentinae.

Subfamily SIPHONOPHRENTINAE, new subfamily

Reference form.-Siphonophrentis gigantea (Lesueur) 1821. Middle Devonian, New York.

These Streptelasmatidae have a narrow to wide septal stereozone, amplexoid septa, and a weak to prominent fossula. Tabulae are mostly complete, straight or domed with axial and peripheral sag. Dissepiments are lacking.

Included are the following genera and subgenera:

Siphonophrentis (Siphonophrentis) O'Connell, 1914

Siphonophrentis (Breviphrentis) Stumm, 1949 (as genus)

Heterophrentis Billings, 1875

Compressiphyllum Stumm, 1949

(?) Nevadaphyllum Stumm, 1937

(?) Homalophyllum Simpson, 1900

Breviphyllum Stumm, 1949 may belong here as a synonym of Breviphrentis. Although defined as a genus with dissepiments, Stumm's holotype of the type species of Breviphyllum (plate 17, figs. 12, 13) does not reveal dissepiments. As noted by W. A. Oliver, Jr. (written commun., 1970), Homalophyllum has a welldeveloped stereocolumella unlike the other genera here included in this subfamily.

The significant generic characters are shape of corallum, width of septal stereozone, prominence of fossula, and rejuvenescence features. Mature corallum shape ranges from elongate-subcyclindrical in Breviphrentis to short and compressed laterally in Compressiphyllum (Oliver, 1958). The septal stereozone is relatively narrow in Siphonophrentis s.s. and some species of Heterophrentis but wide in some species of Breviphrentis and very wide in Nevadaphyllum. Septal length and the spacing and evenness of tabulae are characters of extreme variability within this subfamily. Fossulae are prominent with Heterophrentis, small or unrecognizable in mature coralla of some Siphonophrentis s.s. and in Breviphrentis. Prominent, shelving rejuvenescence flanges, and the narrow elongate corallum set Breviphrentis apart from true Siphonophrentis.

Solitary Rugosa that are here classified as Siphonophrentinae have from time to time been referred to in the literature as zaphrentoid corals or assigned to the Zaphrentidae, a family of uncertain characterization to which they doubtfully belong (Hill, 1938, p. 23; Stumm, 1949, p. 11; Oliver, 1958, p. 816). Status of the Siphonophrentinae with respect to Zaphrentidae calls for evaluation of the type species of Zaphrentis, usually cited as Z. phrygia Rafinesque and Clifford,
1820. Opinions vary widely regarding the characterization of $Z$. phrygia, upon which the validity of the genus and of the Family Zaphrentidae depends. Hill (1956, p. 278 , fig. $190,3 a-b)$ ascribes to Zaphrentis a narrow dissepimentarium and crossbar carinae illustrated by figures of $Z$. phrygia attributed to Schindewolf. Stumm (1964, p. 34, pl. 27, figs. 1-7), on the contrary, regards Z. phrygia as lacking dissepiments and notes the possibility of confusion with carinate Heliophyllum venatum Hall. Obviously, thin section study of topotype material is needed to resolve this taxonomic problem.

Siphonophrentinae and stratigraphic indicators within the early Middle Devonian beds (Onondaga Limestone) of the New York area that are approximately correlative strata of the beds in the Great Basin.

Associated with Siphonophrentinae in the Nevada Formation coral zone $\mathrm{D}_{2}$ are solitary corals that resemble Breviphrentis and Heterophrentis; they differ in having sporadic dissepiments. These problematic individuals are assigned to Sinospongophyllum of the Chonophyllidae, but for some individuals aberrant development of lonsdaleioid dissepiments in a siphonophrentid lineage cannot be entirely ruled out:

\section{Genus SIPHONOPHRENTIS O'Connell 1914}

1914. Siphonophrentis O'Connell, p. 187, 190, 191.

1949. Siphonophrentis O'Connell. Stumm, p. 12-13.

1949. Breviphrentis Stumm, p. 13-14.

1950. Siphonophrentis O'Connell. Wang, p. 214.

1956. Siphonophrentis O'Connell. Hill, p. F271.

1960a. Siphonophrentis O'Connell. Oliver, p. 87-89.

Type species.-By original designation Caryophyllia gigantea Lesueur, 1821, p. 296, 297. Onondaga Limestone, New York State.

Diagnosis.-Oliver's (1960a, p. 87) diagnosis is as follows:

Simple, ceratoid to cylindrical corals with amplexoid septa withdrawn from axis except on and just above upper surfaces of tabulae. Tabulae dome-shaped, flat or concave axially, depressed at the fossula. No axial structure or dissepiments.

Remarks. - Siphonophrentis commonly develops very elongate coralla and may attain large size.

Heterophrentis (type species Zaphrentis spatiosa Billings, 1858) differs in having a curved ceratoid to trochoid or almost turbinate mature corallum with larger and better defined fossula on the convex side and a narrow septal stereozone; the very elongate cylindrical growth habit of Siphonophrentis is lacking. Unlike Siphonophrentis, some mature individuals of Heterophrentis have major septa reaching the axis, where they may be loosely twisted and pervaded by stereome, but not to the extent of forming a discrete axial structure. Tabulae of Heterophrentis are com- 
monly more irregularly arched, less uniform, and more widely spaced than are those of Siphonophrentis. Immature and early mature growth stages of the two genera are probably indistinguishable.

The genus Siphonophrentis lends itself to separation as two subgenera: Siphonophrentis s.s. and Breviphrentis.

Subgenus BREVIPHRENTIS Stumm, 1949 (as genus)

1949. Breviphrentis Stumm, p. 13, 14, pl. 5, figs. 22-24.

1956. Breviphrentis Stumm. Hill, p. F271, fig. 183-6ab.

1960a. Siphonophrentis variabilis Oliver, p. 87-89, pl. 13.

Type species.-Amplexus invaginatus Stumm (1937, p. 427 , pl. 53, fig. 2, pl. 54, figs. 2a-c). Early Middle Devonian, Nevada Formation, unit 2, coral zone $\mathrm{D}_{2}$; Atrypa Peak, Eureka district, Nevada.

Diagnosis.-This narrow, elongate Siphonophrentis is of markedly segmented appearance when fully mature; the cylindrical corallum has deep lateral shelving indentations and rejuvenescence flanges. The cardinal fossula is commonly weak or unrecognizable in the mature calice. The septal stereozone is medium to wide.

Remarks. - Oliver (1960a, p. 87) recognized the morphologic resemblance of Breviphrentis invaginatus to Siphonophrentis. Retention of Breviphrentis as a subgenus seems warranted, as this group constitutes a useful taxonomic unit differing from true Siphonophrentis in its more slender and markedly segmented growth habit. Typical Siphonophrentis is a larger coral when fully mature and lacks the pronounced rejuvenescence flanges; its septal stereozone is relatively narrower.

Breviphrentis is especially characteristic of the Great Basin Early and early Middle Devonian (coral zones C and D). Stumm's proposal of Breviphrentis was made before the stratigraphic importance of these corals was understood. In the New York Early Devonian, Siphonophrentis variabilis Oliver (1960a, p. 87, pl. 13, figs. 1-17) of the Coeymans Limestone resembles Great Basin Breviphrentis more closely than true Siphonophrentis.

Siphonophrentis (Breviphrentis) invaginatus (Stumm)

Plate 15, figures 1-11; plate 16, figures 1-13, 15, 16; plate 17 , figures 12,13 .

1937. Amplexus invaginatus Stumm, p. 427, pl. 53, fig. 2, pl. 54, figs. 2a-c.

1937. (?) Heterophrentis nevadensis Stumm, p. 426, pl. 53, fig. 1, pl. 54, figs. 1a-c.

1937. (?) Amplexus lonensis Stumm, p. 428, pl. 53, fig. 4, pl. 54, figs. 4a-b.

1937. (?) Amplexus nevadensis Stumm, p. 53-54 (in part), pl. 53, fig. 3, pl. 54, figs. 3a-b; not fig. 3c.

1940. Amplexus invaginatus Stumm. Merriam, pl. 16, figs. 34.

1949. Breviphrentis invaginatus (Stumm), p. 13-14, pl. 5, figs. 22-24.
1949. (?) Breviphyllum lonensis (Stumm), p. 25-26, pl. 12, figs. 4-5.

Type material.-Holotype, USNM 94443; paratype USNM 94443a. Lower beds of the Nevada Formation, Atrypa Peak, Eureka mining district, Nevada.

Figured specimens.-USNM 159296-159311 inclusive.

Diagnosis.-This Siphonophrentis has an elongate subcylindrical mature growth habit with several rejuvenescence constrictions. Septal stereozone is narrow to fairly wide. The axial extensions of septa are amplexoid, and the narrow cardinal fossula is either vague or well defined in mature growth stages.

External features.-Neanic and early ephebic growth is ceratoid like Heterophrentis and later ephebic growth subcylindrical, elongate, and with rejuvenescence constrictions. Calice rim flanges are commonly sharp and developed repeatedly at irregular intervals; these flanges are usually broken off. Septal grooves are well defined.

Transverse sections.-Major septa, about 40, normally extend one-half to three-fourths the distance toward the axis; though usually withdrawn from axis in ephebic stages, some individuals have major septa reaching the axis. Minor septa, long for this genus, commonly exceed half the length of major septa. Individuals with a wide septal stereozone have a thickened septa; in some, the complete stereoplasmic filling extends inward almost to the tips of minor septa. Septa are fairly straight to minutely wavy. In some specimens, the cardinal fossula may be defined by the U-shaped trace of the tabular downwarping, but others reveal no evidence of this structure.

Longitudinal sections.-Calice rim rejuvenescence flanges are sharp and project obliquely $8 \mathrm{~mm}$ or more from the coral body. Tabulae, mostly complete, arch distally with a peripheral depression, and are either straight axially and periaxially or have a median sag. Tabellar loops or globose pockets develop near the peripheral edges of the tabulae. Incomplete tabulae are accompanied by flat peripheral tabellae. The regular specimens have more or less complete tabulae that are commonly close spaced. Some irregular individuals have widely spaced nonuniform tabulae. Aberrant individuals have closely spaced, nearly straight tabulae almost unarched.

Comparison with related forms.-Siphonophrentis (Breviphrentis) kobehensis of coral zone $\mathrm{C}$ lacks the well-developed septal stereozone of most variants of zone $\mathbf{D}$ invaginatus and has a lower septal count and very short minor septa.

Siphonophrentis variabilis Oliver of the New York Coeymans Limestone (Oliver, 1960a, p. 87, pl. 13, figs. 1-17) bears a rather close resemblance to invaginatus, 
from which it may differ only subspecifically. Both include individuals with a wide septal stereozone; variabilis is not known to have variants with nearly straight tabulae as does the species invaginatus.

Remarks.-A large suite of Breviphrentis invaginatus from Nevada Formation, unit 2 at Grays Canyon, Eureka district, illustrates the great variability of this species. The highly variable characters are the arching and evenness of tabulae, the spacing of tabulae, and the width of the septal stereozone. Some individuals have straight almost unarched tabulae. The narrow cardinal fossula varies from vague or unrecognizable to fairly well defined in the mature growth stages, similar to Heterophrentis. Local variants have a wide septal stereozone, suggesting that of Kodonophyllum or Pseudoblothrophyllum.

Among variants of $B$. invaginatus at Grays Canyon are individuals with the features of Stumm's Amplexus lonensis holotype, the type species of Breviphyllum. As noted elsewhere, the generic diagnosis of Breviphyllum (Stumm, 1949, p. 26) calls for a dissepimentarium, but no dissepiments were found in the thin sections of the holotype. Other individuals resemble Stumm's Heterophrentis nevadensis.

In longitudinal sections the axial extensions of major septa rest in amplexoid fashion upon the upper surfaces of tabulae.

Occurrence.-Central Great Basin, Nevada Formation, unit 2, Devonian coral zone D. Lone Mountain $\left(D_{2}\right)$ : localities M55, M1036, M1048. Southern Fish Creek Range $\left(D_{2}\right)$ : locality M1033. Northern Fish Creek Range, Grays Canyon $\left(\mathrm{D}_{2}\right)$ : localities M3, M51. Mahogany Hills $\left(\mathrm{D}_{2}\right)$ : localities M27, M1084. Northern Antelope Range $\left(D_{2}\right)$ : locality M1035. Southern Sulphur Spring Range $\left(\mathrm{D}_{2}\right)$ : localities M36, M198, M1078.

Southern Great Basin, Devonian coral zone D. Ranger Mountains: localities M1034, M1058. Northern Panamint Mountains: localities M184, M1065. Funeral Mountains: localities M1059, M1060, M1061, M1063, M1064. Desert Range: locality M1057.

Measurements of Siphonophrentis (Breviphrentis) invaginatus

\begin{tabular}{|c|c|c|c|c|c|}
\hline \multirow[b]{2}{*}{$\begin{array}{l}\text { USNMM } \\
\text { No. }\end{array}$} & & \multicolumn{2}{|c|}{ Ephebic section } & \multicolumn{2}{|c|}{ Neanic section } \\
\hline & & $\underset{(\mathrm{mm})}{\text { Diameter }}$ & $\begin{array}{c}\text { Number of } \\
\text { major } \\
\text { septa }\end{array}$ & $\underset{(\mathrm{mm})}{\text { Diameter }}$ & $\underset{\substack{\text { Number of } \\
\text { mapta }}}{\text { cepta }}$ \\
\hline 159296 & $\ldots$. & 30.5 & 44 & $\ldots$ & $\ldots$ \\
\hline 159298 & ....................... & 29.3 & 40 & .. & $\ldots$ \\
\hline 159306 & .................. & 16 & 32 & 8.3 & 22 \\
\hline 159309 & ...................... & 26.6 & 42 & .... & $\ldots$ \\
\hline
\end{tabular}

Siphonophrentis (Breviphrentis) kobehensis n. ap.

Plate 14, figures 1-15; plate 16, figure 14.

Type material.-Holotype USNM 159284; paratypes USNM 159283, USNM 159285 to 159293 inclusive.
Lower part of the Nevada Formation, Lone Mountain, Eureka County, Nev.

Diagnosis.-This Siphonophrentis has a ceratoid to cylindrical growth habit that reflects frequent rejuvenescence and elongate curved corallites. Septa are withdrawn from axis; minor septa are very short (or unrecognizable). Tabulae are complete, occasionally straight, but more commonly uparched distally and either flat medially or with a slight sag. Tabulae are usually rather widely spaced. The wall has a very narrow stereozone for this genus. There are no dissepiments, but there are occasional looplike or globose tabellae. The abrupt curvature changes on rejuvenescence all caused by the resumption of upright growth by the parent that had been recumbent.

External features.-The segmented appearance of the corallum is caused by the marked constrictions resulting from rejuvenescence. The rim of the parental calice commonly remains a sharp flange distal to which the single daughter corallite may differ in growth direction; for some individuals the direction may diverge $90^{\circ}$; but normally the change is only a few degrees. There are a few weak transverse folds between the rejuvenescence flanges. Septal grooves are well defined.

Transverse sections.-Major septa, about 40 in ephebic stages, are withdrawn to about half the radius; the septa are of fairly uniform width, little thickened by stereoplasm, amplexoid, and resting upon the upper surfaces of the tabulae. The outer wall has a thin septal stereozone beyond which the minor septa project to a distance only about one-fifth the length of the major septa. In a late nepionic stage (diameter, $5 \mathrm{~mm}$ ), the septa number 22; most meet toward the axis but are not otherwise in contact laterally; septa lateral to the cardinal septum are subparallel. At an earlier nepionic stage (diameter $3.5 \mathrm{~mm}$ ) there are about 20 septa within which the cardinal quadrants are recognizable, and the two septa lateral to the cardinal bend inward as they approach the axis, thus defining the primitive fossula. The cardinal fossula, inconspicuous or unrecognizable in later ephebic stages, is probably indicated in transverse sections by a trace which appears to join two major septa in $U$ fashion and which probably conforms to downwarping of a tabula. There are no dissepiments.

Longitudinal sections.-Most tabulae are complete; they vary from straight to uparched distally and peripherally depressed; the axial part is slightly convex distally to flat or sagging. Some individuals have a few localized globose periaxial tabellae. The tabulae are usually spaced rather wide. There are no dissepiments and a very narrow marginal stereozone or none. The tabulae are irregularly uparched where the corallum makes a sharp bend at rejuvenescence. 
Reproductive offsets.-An abnormal corallum shows a cylindrical, curving calice offset of slightly more than half the diameter of the calice rim. This development seems to be an abnormally small rejuvenescence offset terminating growth of the parent after it began secretion of the rejuvenescence shelf.

Comparison with related forms.-Breviphrentis invaginatus possesses a wider septal stereozone and longer minor septa. Siphonophrentis variabilis Oliver of the New York Coeymans Limestone has a wide stereozone and develops tabulae with $\mathrm{M}$-shaped configuration in longitudinal section; straight tabulae are more characteristic of kobehensis.

Measurements of Siphonophrentis (Breviphrentis) kobehensis

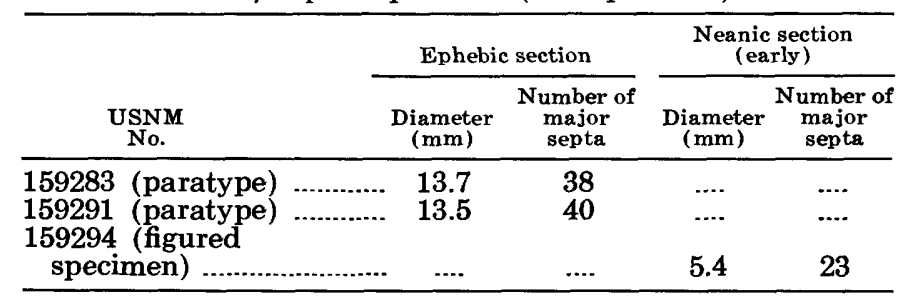

Occurrence.-Lower Devonian (Emsian), coral zone C. West side of Lone Mountain, Eureka County, Nev. localities M286, M74 in lower part of Nevada Formation, unit 1 about 75 feet stratigraphically above base.

Genus NEVADAPHYLLUM Stumm, 1937

1937. Nevadaphyllum masoni Stumm, p. 429, pl. 53, fig. 6, pl. 54, figs. 6a-b.

1949. Nevadaphyllum Stumm, p. 19, pl. 8, figs. 20-21.

1956. Nevadaphyllum Stumm. Hill, p. F271, fig. 183-5.

Type species.-Nevadaphyllum masoni Stumm (by original designation). Nevada Formation, Lone Mountain, Eureka County, Nev.

Diagnosis.-Large ceratoid to cylindrical solitary rugose corals. Many of the very numerous long, smooth major septa reach the axis, toward which they become twisted. There is a wide peripheral stereozone and a fossula. The tabularium is wide; the tabulae numerous, crowded and incomplete, uparched periaxially with axial and periaxial sag. Dissepiments are abnormal or false; the dissepiments are obscured peripherally by the stereozone.

Remarks.-Pseudoblothrophyllum Oliver (1960a, p. 91) has some features of Nevadaphyllum. This Helderbergian genus, as represented by Pseudoblothrophyllum helderbergium, has fewer major septa, a wider stereozone, and a more regular tabularium. As with Nevadaphyllum, the dissepiments are largely suppressed within the wide stereozone.

Nevadaphyllum masoni Stumm

Plate 13, figures 3, 4
1937. Nevadaphyllum masoni Stumm, p. 429, pl. 53, fig. 6, pl. 54, figs. 6a-b.

Type material.-Holotype USM 94447; paratype USNM 94447a. Lower part of the Nevada Formation, Lone Mountain, Eureka County, Nev.

Diagnosis.-See generic diagnosis.

Transverse section.-Major septa, about 76; are smooth and fairly straight for two-thirds of the radius from the wall; they become increasingly wavy and twisted toward the axis which most reach. There is no axial thickening to form a discrete axial structure. Minor septa, less than one-half the length of major septa, become very thin axially. All septa thicken peripherally; some show a very minute waviness. Most of the wide stereozone is apparently infilled by stereoplasm between the septa. The well-defined fossula extends from near the axis into the stereozone and contains a shortened major septum that is assumed to be the cardinal. Laterally the dissepiment traces cannot be distinguished clearly from section plane intersections with the numerous irregular arched tabulae.

Longitudinal section.-The tabularium is a complex of close-spaced irregular tabulae and tabellae lacking straight elements; tabulae are uparched periaxially with a pronounced axial sag. Tabulae and tabellae are poorly separated from elongate false dissepiments in the zone of peripheral sag; axially inclined false dissepiments are obscured peripherally by the wide stereozone. In the axial zone, septal ends and crowded tabulae form a plexus in which the structural details are obscured.

Remarks.-The types of Nevadaphyllum masoni are the only known specimens with the full characterization of this genus. Probably this uncommon multiseptate form with crowded irregular tabulae and modified, obscured dissepiments represents an aberrant evolutionary development from the Breviphrentis stock or perhaps the stock which produced the dissepimented Nevada forms here assigned to Sinospongophyllum. Of these, Sinospongophyllum sp. f with a wide stereozone, obscured nonuniform lonsdaleioid dissepiments, and numerous axially twisted major septa is the closest to $N$. masoni. In this form, however, the tabularium is much less complex.

Occurrence.-Lower part of the Nevada Formation, probably unit 2 and Devonian coral zone $\mathrm{D}_{2}$, early Middle Devonian, Lone Mountain, Eureka County, Nev.

\section{Family KODONOPHYLLIDAE Wedekind, 1927}

Reference form.-Kodonophyllum milne-edwardsi (Dybowski). Silurian, Gotland.

These solitary and colonial rugose corals have long lamellar septa, no fossula at maturity, no dissepiments, 
and a very septal stereozone. The tabularium is composed of flat tabulae or arched tabellae which may combine with septal ends to produce an axial structure.

Two subfamilies are recognized: Kodonophyllinae and Mycophyllinae.

These corals are largely confined to the Silurian rocks; those rather characteristic of the Late Silurian are the Great Basin Silurian coral zone E.

The Kodonophyllinae resemble the Siphonophrentinae by having a wide stereozone; they differ in lacking a mature fossula, in having on the whole a wider, denser stereozone, and in possessing an axial structure supported by arching tabulae and tabellae.

\section{(?)Kodonophyllum sp. f \\ Plate 13, figures 1, 2}

An incomplete Kodonophyllum-like solitary coral with an exceptionally wide septal stereozone was collected from the lower part of the Nevada Formation in the southern Fish Creek Range, where it was associated with Siphonophrentis (Breviphrentis) invaginatus. This species of Siphonophrentis also has a wide stereozone. Because this fragmentary specimen could be prepared only as a transverse section, the possibility of it being an extremely aberrant Breviphrentis or Nevadaphyllum is not eliminated.

A wide, dense stereozone exceeds one-half the corallum radius. The septal count is approximately 66 . Major septa are withdrawn from the axis; minor septa greatly exceed one-half the length of major septa and extend far beyond the stereozone. All exposed septa are thickened and wavy, with numerous protuberances. Tabulae and axial structure are unknown.

The stereozone, similar to that of Pseudoblothrophyllum Oliver (1960a, p. 91, pl. 16), differs in having long, smooth septa, some of which meet the axis. The septa of Pseudoblothrophyllum differ in lacking lobes and by being thinner in the tabularium.

Occurrence.-Nevada Formation, unit 2, Devonian coral zone D. Fish Creek Range, north end of Fenstermaker Mountain: locality M1033.

Kodonophyllum, usually a Silurian genus, has a distinctive axial structure with a calice boss; it is otherwise known only in Late Silurian coral zone $\mathrm{E}$ of the Great Basin Province.

\section{Family STAURIDAE Edwards and Haime 1850}

Reference form.-Stauria astreiformis Edwards and Haime, 1850. Silurian, Gotland.

These fasciculate and cerioid rugose corals have slender corallites, narrow septal stereozone and thin lamellar, nonamplexoid septa that commonly extend to the axis. Tabulae are complete, straight or arched. Dissepiments are commonly absent, but in some line- ages arise as a single column or sporadically in a broken column.

Some species of Stauria reveal a quadripartite mature transverse section in which four primary septa are prominent and may meet at the axis. In the genus Dendrostella, the four primary septa may exceed the others in length, but usually they do not reach the axis of a mature corallum.

Stauriidae include many Late Ordovician species of Favistella Dana (or Favistina Flower), Cyathophylloides Dybowski, and Paleophyllum Billings; these genera carry over into the Silurian. Silurian Stauriidae also include undescribed genera in addition to Stauria. The Devonian representatives are Dendrostella, possibly Columnaria, and possibly Synaptophyllum Simpson, as revised by McLaren (1959).

\section{Genus DENDROSTELLA Glinski, 1957}

1886. Cyathophylloides rhenanum Frech, p. 93, pl. 3 (15), figs. 19, 19a.

1892. Columnaria (Cyathophylloides) disjuncta Whiteaves, p. 269 , pl. 34, figs. 3, 3a, 3b.

1957. Favistella (Dendrostella) rhenana (Frech). Glinski, p. 88-90, figs. 1-4, 16.

Favistella (Dendrostella) praerhenana Glinski, p. 9091, figs. $5,14$.

Type species.-Cyathophylloides rhenanum Frech (by original designation, Glinski, 1957). Upper Middle Devonian, Givetian, "Bücheler Schichten", Paffrath Basin, Germany.

Diagnosis.-These slender dendroid and phaceloid rugose corals have a thick wall, no dissepiments, smooth, simple, even, nonamplexoid and unthickened septa; minor septa are short or lacking. Tabulae are complete, either straight or with a slight doming or sag.

Remarks.-Dendrostella was proposed by Glinski as a subgenus under Favistella; however, it appears suffciently well characterized and distinctive to be considered a full genus. Denstrostella commonly has short septa which are not truly amplexoid because they are not developed only on the upper surfaces of tabulae. Glinski states that the range is from Silurian (upper Ludlovian) to Middle Devonian (Givetian). In the Great Basin the only known occurrence is in Nevada Formation, unit 2, possibly coral zone $\mathrm{D}_{3}$ which would be about early Eifelian.

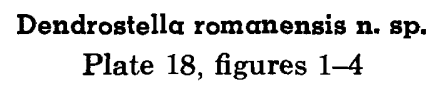

Type material.-Holotype USNM 159318; Nevada Formation, Devonian coral zone D. Locality M1031, Sulphur Spring Range.

Diagnosis.-Dendrostella has relatively short major septa and very short to completely suppressed minor septa. There is no indication of transversely bilateral 
pattern of septa.

External features.-Phaceloid colonies are many centimeters wide with long, slender branching fairly straight corallites loosely arranged. Surface has fine longitudinal grooves and striae; transverse rugae are weak. No lateral connecting processes were observed.

Transverse sections.-Major septa, about 20, commonly extending less than half the distance to the axis. Minor septa pass only a short distance beyond the wall or are represented only by roots within the thick wall. The wall is divided circumferentially into about 40 equal radial parts (segments) by dark hairthin lines, one segment for each septum root. Septa have median dark lines.

Longitudinal sections.-Thickened wall has minor undulations, but no sharp bends or angular rejuvenescence features. Tabulae are all complete, not widely separated, straight to undulant, but lack a persistent axial arch or depression. There are no dissepiments.

Comparison with related forms.-Dendrostella romanensis $\mathrm{n}$. $\mathrm{sp}$. has shorter major septa than rhenana (Frech) and praerhenana Glinski; unlike romanensis, these west European forms have a suggestion of symmetry with primary septa distinguishable in mature stages. Dendrostella disjuncta (Whiteaves) also has long major septa and longer minor septa than romanensis.

Measurements.-Diameter (in $\mathrm{mm}$ ) and major septa, three corallites of holotype colony, USNM 159318:

\begin{tabular}{|c|c|c|}
\hline Corallite $\ldots \ldots \ldots$ & 2 & 3 \\
\hline Diameter $(\mathrm{mm}) \ldots 9$ & 8 & 7.5 \\
\hline Major septa $\ldots \ldots \ldots 20$ & 20 & 20 \\
\hline
\end{tabular}

Occurrence.-In somewhat arenaceous limestone of Nevada Formation, unit 2, Sulphur Spring Range, northwest of Romano Ranch: locality M1031. The coral-bearing bed lies about 150 feet stratigraphically above sandy limestone with a large fauna including Spirifer pinyonensis, Breviphrentis cf. B. invaginatus, and Leonaspis sp.; this fauna probably represents coral zone $\mathrm{D}_{2}$. The Dendrostella occurrence may be in coral zone $\mathrm{D}_{3}$. The other North American occurrence of Dendrostella recorded by Whiteaves $(1892$, p. 269270 ) apears to be in rocks of Givetian age, as suggested by association with Stringocephalus at Lakes Manitoba and Winnipegosis. Glinski (1957, p. 105) records $D$. praerhenana as Eifelian in the lower Nohner beds, and $D$. rhenana as Givetian in the Bücheler beds, both in the Rhine Valley region. The horizon of romanensis is probably closer to Eifelian than Givetian.

\section{Family HALLIIDAE Chapman, 1893}

Reference form. - Hallia insignis Edwards and Haime, 1850. Devonian, Ohio.
These medium and large solitary rugose corals have distinctly bilateral symmetry. Septa are numerous, long and smooth; cardinal septum is in a prominent fossula. Tabulae are wide, partly complete, normally domed with an axial sag. Dissepimentarium is narrow to wide; dissepiments are normal, globose, and lonsdaleioid. Septal thickening persists to adult growth stages in cardinal quadrants.

The Halliidae are the abundant Rugosa of the Great Basin Lower Devonian, where they characterize coral zones $\mathrm{B}$ and $\mathrm{C}$; they diminish in importance in coral zone D.

Two subfamilies constitute the Halliidae: the Halliinae of the Early and Middle Devonian, and the Papiliophyllinae of the Early Devonian. The lykophyllid corals of the Silurian, which have been classified with the Halliidae by Hill (1956, p. F272), are here regarded as a separate family, the Lykophyllidae of Wedekind.

\section{Subfamily HALLIINAE Chapman, 1893}

Reference form.-Hallia insignis Edwards and Haime, 1850. Devonian, Ohio.

The Halliidae have an especially well defined pinnate arrangement of septa in cardinal quadrants. The dissepimentarium, narrow to wide, is made up of normal dissepiments only.

Genera of this widely occurring subfamily are Hallia Edwards and Haime, Aulacophyllum Edwards and Haime, and Odontophyllum Simpson; of these, Aulacophyllum and Odontophyllum occur in the Great Basin Devonian coral zone C.

\section{Subfamily HALLIINAE Chapman, 1893 Genus AULACOPHYLLUM Edwards and Haime, 1850 Aulacophyllum sp. c Plate 9, figures 6-9}

Medium and fairly large solitary corals of this kind occur in coral zone $\mathrm{C}$ at Lone Mountain in association with Papiliophyllum elegantulum and Odontophyllum meeki. Unlike Papiliophyllum they do not possess lonsdaleioid dissepiments, and accordingly they seem more appropriately assigned to Aulacophyllum. The strong thickening of cardinal quadrant septa persists into mature growth stages.

Occurrence.-Nevada Formation, unit 1. Early Devonian, coral zone C. Lone Mountain, Eureka County, Nev.: Locality M74.

Other Aulacophyllum-like Rugosa of coral zone C have thickened septa in contact laterally through the neanic stage but are largely devoid of dissepiments. These occur at locality M74 (pl. 9, figs. 10, 12) and in the southern Sulphur Spring Range at locality M36 (pl. 9, fig. 11). 
Genus ODONTOPHYLLUM Simpson, 1900

1882. Aulacophyllum convergens Hall, p. 22.

1833. Aulacophyllum convergens Hall, p. 281, pl. 17, figs. 1-2.

1900. Odontophyllum Simpson, p. 210.

1938. Odontophyllum Simpson. Stewart, p. 31, pl. 5, figs. 5-6.

1948b. Odontophyllum Simpson. Stumm, p. 51-59, pls. 1-2.

1949. Odontophyllum Simpson. Stumm, p. 16, pl. 7, figs. 1314.

1956. Odontophyllum Simpson. Hill, p. F273, fig. 186-2a-c.

1964. Odontophyllum Simpson. Stumm, p. 29-30, pl. 19, figs. $5-13$.

Type species.-Aulacophyllum convergens Hall by original designation. Middle Devonian; Beechwood Limestone Member of the Sellersburg Limestone, Falls of the Ohio, near Louisville, Kentucky (Stumm, 1964, p. 4).

Diagnosis.-These solitary curved turbinate and curved trochoid to subpatellate Halliidae have a broad and commonly very deep calice. Cardinal septum is on the convex side in the long narrow fossula. Alar fossulae are defined, but no counter fossula. Major septa extend to the axis; septa are denticulate at distal edges. Some species have carinate septa. Tabulae are incomplete, distally arched. Dissepiments are present near the periphery in the late growth stages.

Remarks.-Neanic stages of $O$. convergens (Hall) that are figured by Stumm (1948b, pl. 1, fig.11) show their affinity with the Halliidae: having cardinal-counter bilateral symmetry, short cardinal septum, and septa of cardinal quadrants subparallel bordering the counter septum and bending inward toward the counter as the axis is approached. Longitudinal sections of individuals with a very broad shallower calice have tabularium with tabellae and a narrow dissepimentarium. Specimens that are here described from the lower part of the Nevada Formation have a deep calice extending downward to the nepionic growth so that transverse sections show little structure.

$$
\begin{gathered}
\text { Odontophyllum meeki n. sp. } \\
\text { Plate 9, figures 1-5 }
\end{gathered}
$$

Type material.-Holotype USNM 159261; paratype USNM 159262. Lone Mountain, locality M74; Devonian coral zone $\mathrm{C}$.

Diagnosis.-This Odontophyllum has a curved trochoid to curved turbinate corallum and a wide, deep calice extending downward to or almost to nepionic growth. Cardinal and alar fossulae are well developed. Cardinal septum are strongly developed and long in mature calices. Septa of counter quadrants are shorter and much less prominent in a mature calice than the septa of the cardinal quadrants. Some septa are slightly denticulate at the distal margins but have no development of true carinae. The distal margins of the calice are thin and sharp because there is no peripheral platform as in some individuals of $O$. patellatum (Holmes). The exterior has sharply defined septal grooves.

Remarks.-This species shows extremely well the pinnate arrangement of septa and septal insertion with reference to primary septa. Associated with $O$. meeki are other nondissepimented solitary trochoid rugose corals having a deep calice and sharp rim, but with the fossulae not so well defined (plate 9, figs. 13, 14). These have narrowly cylindrical or ceratoid early growth stages which may be elongate, stemlike, and distorted. They differ from associated early growth stages of Papiliophyllum; though lacking dissepiments in the early growth stages, these have thickened septa, especially in the cardinal quadrants.

Measurements.-Holotype: Diameter at calice rim $30 \mathrm{~mm}$, corallum length $34 \mathrm{~mm}$, calice depth $26 \mathrm{~mm}$; major septa at calice bottom 36 .

Occurrence.-Nevada Formation, Early Devonian, coral zone C. Lone Mountain, Eureka County, Nev.: locality M74.

\section{Subfamily PAPILIOPHYLLINAE Stumm, 1949}

Reference form. - Papiliophyllum elegantulum Stumm, 1937. Lower Devonian, coral zone C, Great Basin.

These large Halliidae have a peripheral band of lonsdaleioid dissepiments; normal dissepiments are few or absent. Septal thickening is commonly strong in mature cardinal quadrants.

Genera of this endemic subfamily are Kobeha $\mathbf{n}$. gen. of coral zone B, Papiliophyllum Stumm of coral zones $\mathrm{C}$ and $\mathrm{D}_{1}$, and Eurekaphyllum Stumm of coral zone C.

\section{Genus KOBEHA, new genus}

Type species.-Kobeha walcotti n. sp., here designated.

Diagnosis. - These large solitary Papiliophyllinae have curved trochoid and curved ceratoid to subcylindrical shape. The calice is deep, rather flat bottomed with nearly erect, straight walls and an acute margin without platform. The outer wall has a narrow septal stereozone. The cardinal fossula are well defined, usually on the convex side of the corallum. The major septa of mature individuals number about 60 , some of which nearly reach the axis. Minor septa are short. In nepionic and early neanic stages, septa that are thickened by the stereome are laterally in contact, and largely filling the interior. In mature stages the septal dilation progressively decreases and becomes confined mostly to cardinal quadrants. Advanced stages have attenuate septa in counter quadrants and those of cardinal quadrants are also thinned, the attenuation is progressively peripherally from the axis. Tabularium is 
broad, 60-80 percent of mature corallum width; tabulae are numerous, normally closely spaced. Some tabulae are continuous with the axial sag, others are as wide as the tabellae which are domed and discontinuous. The dissepimentarium has one to three columns of large steeply inclined dissepiments, some of which are exceedingly large wall blasts.

Because of the large size and small number of wall blasts and other large peripheral dissepiments, the transverse sections through the mature corallum do not show a conspicuous lonsdaleioid outer zone. The peripheral zone of large dissepiments is well shown only in longitudinal sections.

Remarks. - Kobeha has thus far been recognized only in the central Great Basin. K. walcotti is the characterizing species of the Lower Devonian Kobeha zone, which is coral zone B of the central Great Basin Devonian. Kobeha ketophylloides $\mathrm{n}$. sp. is placed in this new genus with reservation, but it seems to fit best here. Kobeha precedes, and is conceivably ancestral to, other Halliidae of this region, which include Papiliophyllum of coral zone C and Eurekaphyllum. Eurekaphyllum is regarded as a synonym of Papiliophyllum by some investigators (Hill, 1956, p. F273).

Kobeha walcotti n. gen., n. sp.

Plate 3, figures 1, 2, 6; plate 4, figures 1-4; plate 5 , figures $1-7$; plate 6 , figures 8-10

1940. Zaphrentoid sp. cf. Papiliophyllum; Merriam, pl. 12, fig. 5 .

Type material. - Holotype USNM 159253; paratypes USNM 159251, 159252, 159256, 159257, 159260.

Nevada Formation, lower beds of unit 1; Devonian coral zone B, Early Devonian. Southern Sulphur Spring Range, Nev.

Diagnosis. - Kobeha without continuous lonsdaleioid dissepimentarium showing as a complete peripheral band in mature transverse sections. Longitudinal sections show one to three columns of lonsdaleioid dissepiments, most of which are large wall blasts. All septa are thinned in late ephebic stages; major septa are discontinuous peripherally, but the outermost segments are uniform and complete at their union with the narrow septal stereozone. Major septa occur as partly discontinuous septal crests on the upper sur- faces of tabulae. Tabulae are downwarped at the cardinal fossula, which is not confined in all individuals to the convex side of the corallum. Calice is nonconical with a broad bottom which is nearly flat to shallowly concave distally.

External features.-Corallum is curved trochoid to ceratoid in the neanic stages; it becomes nearly cylindrical in mature stages of large individuals. Septal grooves are commonly separated by longitudinal ridges with a minor secondary groove on the crest of each ridge. Transverse features (rugae) vary from fine growth striations to fairly prominent ring-folds at irregular intervals. Regularly spaced rejuvenescence features are absent, but irregular breakage and repair structures are common and define the broken calice rim. Bell-shaped to flowerpot-shaped calice has an almost flat bottom and nearly erect sides below a sharp rim. The tabular floor of the calice is downwarped in the cardinal fossula, which may be situated either on the convex side or laterally.

Transverse sections.-In advanced ephebic stages, the major septa number at least 70 , all of which may be thinned. Stereoplasmic thickening of the septa in the cardinal quadrants persists into the earlier ephebic stages. The wall is a narrow septal stereozone. Some major septa reach the axis in the early ephebic stages; minor septa are short, usually less than one-seventh the length of the radius. Traces of large wall blasts are concave peripherally and encompass as many as six major septa. Between septa where the section intersects tabellae, the traces are usually concave peripherally; these features do not make a concentric pattern.

Late neanic to early ephebic transverse sections usually show the cardinal quadrants filled with stereoplasmic deposits and the septa with thickening in the counter quadrants. Septa are progressively thinned, beginning axially in the counter quadrants. Thickened septa in the cardinal quadrants are pinnate, but it is difficult to ascertain which of two or three shortened septa is actually the cardinal septum in some neanic sections. Late nepionic and early neanic transverse sections show stereoplasmic thickening of all septa; septa in contact laterally completely fill the corallum.

Measurements of Kobeha walcotti n. sp.

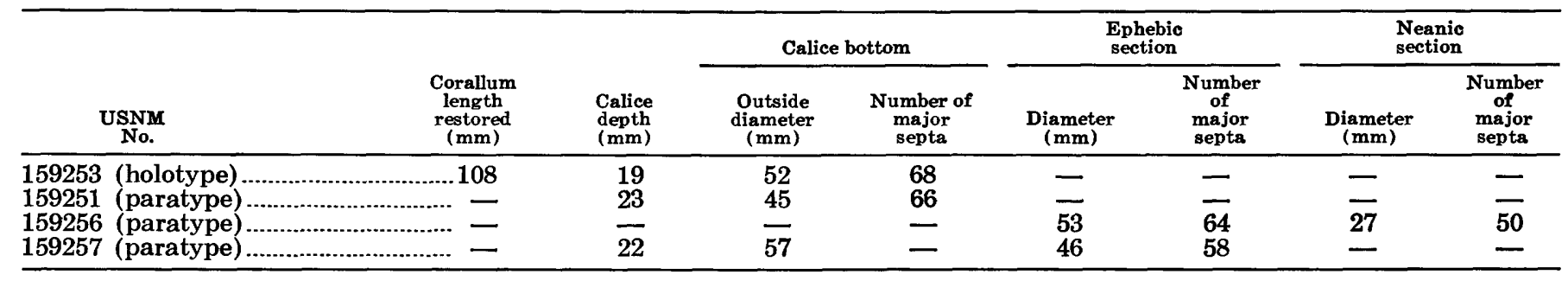


Longitudinal sections. - The tabularium, wide in mature longitudinal section, is as much as four-fifths of the total diameter. Complete or nearly complete tabulae commonly have a slight median sag, and wide tabellae. Tabulae are closely spaced to widely separated, downwarped at the tabularium margin, with a pronounced sag at the cardinal fossula. Large lonsdaleioid dissepiments are normally in one or two columns, steeply inclined to nearly vertical. Axial extensions of major septa are carried on the upper surfaces of tabulae.

Comparison with related forms.-Kobeha ketophylloides differs from $K$. walcotti by having larger less uniform wall blasts as observed in mature transverse sections, wherein these features are more prominent and more irregularly distributed. The number of dissepiment columns is greater in K. ketophylloides, and the mature dissepiments are less steeply inclined than in K. walcotti. In K. ketophylloides marked discontinuities of major septa where they meet wall blasts are more numerous.

Occurrence.-Lower part of the Nevada Formation, basal beds of unit 1; Early Devonian, coral zone B with Costispirifer arenosus. Southern Sulphur Spring Range: localities M4, M56, M67, M69, M1041. Northern Roberts Mountains: locality M1072. Northern Sulphur Spring Range, McColley Canyon: locality M1018; specimens from this area differ subspecifically from typical $K$. walcotti.

Kobeha ketophylloides n. sp.

Plate 3, figures 3-5, 8, 9; plate 6, figures 1-7

Type material. - Holotype USNM 159258; paratypes USNM 159254, 159255, 159259. Lower Devonian, Nevada Formation, unit 1; coral zone B. Southern Roberts Mountains and Southern Sulphur Spring Range, Nev.

Diagnosis.-Kobeha has very large and irregularly distributed wall blasts and lonsdaleioid dissepiments in mature transverse sections; these peripheral features are circumferentially uneven and show marked discontinuities of the major septa, segments of which thicken in wedge fashion to terminate peripherally against dissepiments or wall blasts. Individual wall blasts subtend as many as 13 septa. Longitudinal sections have as many as seven columns of wall blasts and lonsdaleioid dissepiments which decrease distally in steepness of axial inclination to $40^{\circ}$.

External features.-A large trochoid specimen with deep bell-shaped, rather flat-bottomed calice shows the cardinal fossula. Broken calice rim reveals the cone-in-cone structure with wide irregular separations making the characteristic wall blasts and lonsdaleioid dissepiments.

Transverse sections.-In advanced ephebic stages major septa number 64 . Minor septa are usually less than half the radius but are longer than those of $K$. walcotti. In advanced ephebic stages the septa are thicker at the periphery in counter quadrants than in $K$. walcotti and there are wide discontinuities where major septa meet large dissepiments at which points the septa thicken in wedge fashion locally. In later ephebic stages septa in cardinal quadrants exceed in thickness those of the counter quadrants; in earlier ephebic stages all major septa are of about the same thickness. Septa are thickened and laterally in contact in later nepionic stages, separating in early neanic stages; in late neanic stages septa of counter quadrants are thinner than those of cardinal quadrants. The outer wall has a septal stereozone which in late neanic stages is $2 \mathrm{~mm}$ thick. Large irregular dissepiments and wall blasts are concave peripherally.

Longitudinal sections.--Most of the wide and rather closely spaced tabulae arched distally with a median sag, and are for the greater part nearly continuous. Short tabellae are uncommon. Large lonsdaleioid dissepiments are fairly even and regular in curvature longitudinally though irregular transversely; dissepiments decrease in steepness from early to late ephebic stages where the axial inclination is about $40^{\circ}$. The number of columns in the dissepimentarium increases to seven at maturity; this fact distinguishes the species from $K$. walcotti, the type species.

Reproductive offsets. - A well-preserved silicified specimen assigned to $K$. ketophylloides shows four peripheral calice buds. The main corallite was itself developed as a calicinal offset from the partially preserved parent.

Measurements of Kobeha ketophylloides n. sp.

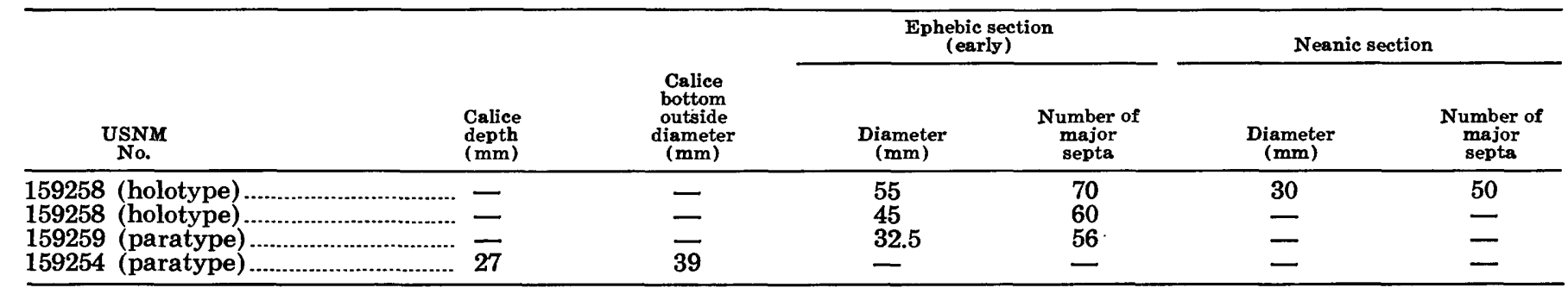


Comparison with related forms.-Kobeha ketophylloides differs from $K$. walcotti in having a larger number of mature dissepiment columns, in its more conspicuous lonsdaleioid separations in advanced ephebic transverse sections, and longer minor septa. Heavy thickenings of septa in cardinal quadrants were not observed to persist ontogenetically into ephebic stages of $K$. ketophylloides as they do in some individuals of $K$. walcotti. The tendency for subcyclindrical growth in advanced ephebic stages is greater than in $K$. walcotti. Calice reproductive offsets were not recognized in K. walcotti.

In mature pattern of construction Kobeha ketophylloides resembles the species of Ketophyllum from the Silurian of Gotland, that is figured by Wedekind (1927) and the species from the Silurian of Czechoslovakia of Počta (1902). The septal discontinuities of Ketophyllum are greater and lonsdaleioid separations more pronounced. Unlike Kobeha, the wide tabulae of Ketophyllum are usually rather flat, whereas those of Kobeha are strongly arched distally and have a median sag. Kobeha ketophylloides has thickened septa in the neanic and earlier growth stages, especially in the cardinal quadrants; the developmental thinning of the septa begins peripherally in the neanic growth within the counter quadrants, a characteristic feature of Kobeha and Papiliophyllum ontogeny. Wedekind's figures $(1927, \mathrm{pl}$. 10, figs. 8-11) of the neanic stages of Ketophyllum elegantulum do not show thickened septa and the septa are short neanically, whereas in Kobeha ketophylloides the septa are thickened and approach the axis. These early developmental differences by themselves are believed sufficient to justify not assigning the Nevada forms to Ketophyllum.

Occurrence.-Lower part of the Nevada Formation, lower beds of unit 1. Early Devonian, coral zone B, southern Roberts Mountains: type locality M1042. At the type locality, $K$. ketophylloides is associated with a Gypidula that resembles G. coeymanensis, Acrospirifer sp., Leptocoelia sp., and a brachipod that resembles the Pholidostrophia of the Rabbit Hill Helderberg. This horizon may be slightly older than the beds that contain specimens assigned to $K$. ketophylloides in the Sulphur Spring Range. Southern Sulphur Spring Range: localities M69, M1039.

Genus PAPILIOPHYLLUM Stumm, 1937

1937. Papiliophyllum elegantulum Stumm, p. 430.

1940. Papiliophyllum elegantulum Stumm, Merriam, p. 52, 53, pls. 12, 16.

1949. Papiliophyllum elegantulum Stumm, p. 16, pl. 7.

1956. Not Papiliophyllum Hill, p. F274, fig. 186, 4c, 4d.

Type species.-By original designation Papiliophyllum elegantulum Stumm (1937, p. 430, pl. 53, fig. 7, pl. 54, fig. 7a-e). Lone Mountain, Eureka County, Nev.; lower part of Nevada Formation, unit 1, Lower Devonian (Emsian), coral zone C.

Diagnosis.-Solitary trochoid and ceratoid Halliidae which grow to a large size have a deep flowerpotshaped, rather flat-bottomed calice with a cardinal fossula. Peripheral zone has medium to large steeply inclined lonsdaleioid dissepiments. Septa of cardinal quadrants are thickened in all the ephebic stages and are laterally in contact in all the early ephebic stages. Most septa are withdrawn from the axis and terminate peripherally at the inner margin of the lonsdaleioid dissepimentarium. Minor septa are either suppressed or inconspicuous as short discontinuous crests. In the neanic stages the cardinal septum is short within the fossula which is bordered by thick septa touching laterally. Tabulae are mostly complete, wide, close to rather widely spaced, and distally arched; in normal mature stages tabulae are rather flat to slightly sagging axially and periaxially and are peripherally depressed. Some individuals have tabulae that are rather irregular and sharply arched distally in the neanic stages. Tabulae are bent sharply downward, funnellike at the cardinal fossula. Septa of the counter quadrants become thinned and lonsdaleioid dissepiments develop in the early to mid-neanic stages; the cardinal quadrants are bordered by lonsdaleioid dissepiments externally until late neanic or early ephebic stages.

Remarks. - The diagnosis here given is modified slightly from that of Stumm (1949, p. 16). Of special significance is the seeming absence of minor septa in some mature transverse sections, although in some specimens minor septa are recognizable as weak crests near the peripheral border of the tabularium. Also important taxonomically is the absence of lonsdaleioid dissepiments in the cardinal quadrants until the late neanic stage.

Papiliophyllum differs from Kobeha in having a better defined dissepimentarium with smaller and more numerous lonsdaleioid dissepiments, especially in the mature transverse sections. In Kobeha the septal crests carry through to the outer wall; they do not in Papiliophyllum. Minor septa are better defined and more continuous in Kobeha.

Papiliophyllum differs from Eurekaphyllum in possessing much more numerous and smaller lonsdaleioid dissepiments. Eurekaphyllum shows widely spaced tabulae with a pronounced axial-periaxial sag, whereas Papiliophyllum usually shows distally arched commonly close-set tabulae.

Papiliophyllum elegantulum Stumm

Plate 7, figures 4-10; plate 8, figures 1-8 
1937. Papiliophyllum elegantulum Stumm, p. 430; pl. 53, fig. 7, pl. 54, figs. 7a-e.

1940. Papiliophyllum elegantulum Stumm. Merriam, p. 52-53, pl. 12, fig. 3, pl. 16, figs. 1, 2.

1949. Papiliophyllum elegantulum Stumm, p. 16; pl. 7, figs. 11, 12.

1956. Papiliophyllum elegantulum Stumm. Hill, p. F274, fig. 186-4a-4b.

Type material.-Stumm's transverse thin section of the holotype is similar to the transverse section of Merriam (1940, pl. 16, fig. 1) made by cellulose peel. The holotype is one of the fossils from the Nevada Formation presented by Merriam to the U.S. National Museum. Paratype, USNM 94448. Lower part of the Nevada Formation, unit 1, Lone Mountain, Eureka County, Nev.

Diagnosis.-This is a large Papiliophyllum. The width of the mature lonsdaleioid dissepimentarium is less than half the radius and consists of three to seven columns of medium to large, steeply inclined dissepiments. Some tabulae are complete, arched distally. They are usually flattened axially and periaxially in the ephebic stages and commonly are arched more deeply and rather irregularly in the neanic stages. In advanced ephebic stages the dissepimentarium is narrowest at the cardinal fossula; the thickened septa bounding the fossula invade this peripheral band. Minor septa are weakly developed or unrecognizable. Septa of the cardinal quadrants are heavily to moderately thickened in the ephebic stages.

External features.- These curved trochoid or curved ceratoid corals usually have well-defined septal grooves but commonly do not show very pronounced annular folds or rugae; these features suggest fairly continuous growth. The outer wall is commonly broken away in the places where large wall blasts occur within. The deep and rather flat-bottomed calice is bordered in mature specimens by blisterlike lonsdaleioid dissepiments; on the axial surfaces of these dissepiments lie septal crests that become weaker toward the rim. There is no calicular shelf.

Transverse sections.-Mature transverse sections have an average of about 56 major septa, some of which reach or nearly reach the axis. Minor septa occur as thin discontinuous crests toward the peripheral edge of the tabularium; some mature individuals show almost no trace of minor septa. Septal crests are rarely observed within the dissepimentarium and almost never meet the wall. In advanced ephebic stages the width of the dissepimentarium varies from less than one-third to more than one-third of the radius. The dissepiments lack uniformity, ranging in size from small to very large and they subtend 12 or more septa. In late ephebic stages septa of the counter quadrants are always thinned; those of the cardinal quadrants are thickened and commonly several remain laterally in contact. The cardinal septum is shortened or aborted in a fossula which encroaches peripherally upon the dissepimentarium.

In the mid-neanic stages there are about 38 septa. The septa vary from being all thickened and laterally in contact with one another to being considerably thinned in the counter quadrants, and some of those in the cardinal quadrants are partly separated even though they are thick. At the mid-neanic stage, but usually a bit later, lonsdaleioid wall blasts begin to develop in the counter quadrants only. The cardinal septum roughly defines a plane of symmetry; on either side of this plane the thickened septa are more or less parallel near the periphery but bend laterally toward this plane as they pass axially, some join near the axis to produce a primitive fossula. Counter and alar septa are not distinguishable with assurance. In early ephebic stages lonsdaleioid dissepiments are generally not developed or are just beginning to develop in the cardinal quadrants, and the thick septa are here largely or partly in contact laterally.

Longitudinal sections.-In advanced ephebic stages the tabularium width exceeds one-half the corallite diameter. Sections parallel to the alar plane show fairly uniform, distally arched tabulae, some of which are complete and accompanied by wide tabellae. The broad axial-periaxial part of the tabularium is flat or has a slight sag, the peripheral part sags abruptly. In neanic stages the tabular uparching is more pronounced and axially convex to angular distally. Medial sections through the cardinal fossula reveal the ex-

Measurements of Papiliophyllum elegantulum Stumm

\begin{tabular}{|c|c|c|c|c|c|c|c|c|}
\hline \multirow{2}{*}{\multicolumn{2}{|c|}{$\begin{array}{c}\text { Figured } \\
\text { specimen }\end{array}$}} & \multirow[b]{2}{*}{$\begin{array}{c}\text { Corallum } \\
\text { length } \\
\text { restored } \\
(\mathbf{m m})\end{array}$} & \multirow[b]{2}{*}{$\begin{array}{l}\text { Calice } \\
\text { depth } \\
(\mathrm{mm})\end{array}$} & \multirow{2}{*}{$\begin{array}{c}\text { Calice } \\
\text { bottom } \\
\text { outside } \\
\text { diameter } \\
(\mathrm{mm})\end{array}$} & \multicolumn{2}{|c|}{ Ephebic section } & \multicolumn{2}{|c|}{ Neanic section } \\
\hline & & & & & $\underset{(\mathrm{mm})}{\text { Diameter }}$ & $\begin{array}{c}\text { Number of } \\
\text { major } \\
\text { septa }\end{array}$ & $\underset{(\mathrm{mm})}{\text { Diameter }}$ & $\begin{array}{c}\text { Number of } \\
\text { major } \\
\text { septa }\end{array}$ \\
\hline $\begin{array}{l}1 \\
2\end{array}$ & . & $\begin{array}{l}51 \\
\cdots . .\end{array}$ & 22 & 23 & $\ldots$ & $\cdots$ & $\begin{array}{l}19.8 \\
21\end{array}$ & $\begin{array}{l}44 \\
38\end{array}$ \\
\hline 3 & . & $\ldots$ & $\cdots$ & $\ldots$ & $\ddot{82}$ & $\dddot{68}$ & .... & $\ldots$ \\
\hline 4 & . & $\cdots$ & $\ldots$ & $\ldots$ & 46 & 52 & .... & $\ldots$ \\
\hline 5 & ....................... & .... & $\ldots$ & .... & 45 & 58 & .... & $\ldots$ \\
\hline
\end{tabular}


tensive stereoplasmic septal thickening and the pronounced funnellike proximal sag of tabulae associated with the fossula. Columns of lonsdaleioid dissepiments number seven or more in the advanced ephebic stages; dissepiments vary greatly in size, and smaller ones are scattered throughout. Very large wall blasts are common, but large dissepiments seen in some specimens may also occur at the axial margin of this band.

Comparison with related forms. - Papiliophyllum elegantulum seems to have evolved from the same stock that also gave rise to Kobeha and Eurekaphyllum, which are discussed elsewhere under their definitions of genera. Papiliophyllum elegantulum differs from Kobeha walcotti in having smaller and more numerous lonsdaleioid dissepiments and in not having septal crests within the dissepimentarium - the absence of these crests is a diagnostic feature of $K$. walcotti. Eurekaphyllum breviseptatum differs in having only a few very large wall blasts and lonsdaleioid dissepiments and in having its very widely spaced tabulae which are depressed proximally, not arched distally as in $P$. elegantulum.

Occurrence.-Lower part of the Nevada Formation, unit 1; Devonian coral zone C of late Early Devonian age, approximately Emsian. Associated with Acrospirifer kobehana. Lone Mountain: localities M74, M286, M1044. Southern Roberts Mountains: locality 18 of Merriam (1940). Northern Roberts Mountains: localities 13, 94 of Merriam (1940). Southern Sulphur Spring Range: locality M68. North end of Antelope Range: locality M1035a. Hot Creek Range: locality M1066?. Northern Panamint Mountains, California: localities M184, M1065. Funeral Mountains, California: localities M1059, M1063.

Papiliophyllum elegantulum subsp. $d$ Plate 7, figures 1, 2

This subspecies is insufficiently known to characterize. It is an evolutionally advanced and a geologically younger derivative of the elegantulum lineage with very numerous lonsdaleioid dissepiments and crowded fairly uniform wide tabulae that are only slightly arched.

Measurements.-Diameter of the late ephebic section is $78 \mathrm{~mm}$; the number of major septa is 62 .

Occurrence.-Lower part of the Nevada Formation, unit 2. Devonian coral zone $\mathrm{D}_{1}$ of late Early Devonian age. Lone Mountain: locality M1037; associated with Sinospongophyllum sp. d, Chonetes macrostriata, Gypidula loweryi, Spirifer pinyonensis, and Dalmanites meeki. Ranger Mountains, Clark County, Nev.; a similar Papiliophyllum occurs here at locality M1034, associated with a fauna which may be that of coral zone $\mathrm{D}_{\mathbf{1}}$.

\section{Genus EUREKAPHYLIUM Stumm, 1937}

1937. Eurekaphyllum breviseptatum Stumm, p. 431, pl. 53, fig. 8; pl. 54, figs. 8a-b.

1940. Eurekaphyllum Stumm. Lang, Smith, and Thomas, p. 58.

1949. Eurekaphyllum Stumm, p. 17, pl. 7, figs. 15-17.

1956. Papiliophyllum Stumm (in part). Hill, p. F273 (in part), fig. 186-4c-d.

Type species. - Eurekaphyllum breviseptatum Stumm (by original designation). Lower part of the Nevada Formation, Lone Montain, Eureka County, Nev.

Diagnosis.-Large curved trochoid Papiliophyllumlike rugose coral with a peripheral zone of very large irregular lonsdaleioid dissepiments and widely spaced irregular wide tabulae which are axially depressed. Inner ends of the septa are withdrawn some distance from the axis; septa of the cardinal quadrants are thickened. Septal crests are present in the dissepimentarium.

Remarks.-Eurekaphyllum has the lonsdaleioid dissepiments and thickened mature cardinal quadrant septa of Papiliophyllum and Kobeha, but differs from both in possessing exceedingly large irregular dissepiments and in having a small number of tabulae, most of which sag proximally. In transverse section, Eurekaphyllum resembles Kobeha in having septal crests within the dissepimentarium; Papiliophyllum commonly lacks these outer crests and differs in having a much greater number of dissepiment columns.

\section{Eurekaphyllum breviseptatum Stumm Plate 8, figures 9, 10}

1937. Eurekaphyllum breviseptatum Stumm, p. 431, pl. 53, fig. 8, pl. 54, figs. 8a-b.

1949. Eurekaphyllum breviseptatum Stumm, p. 17, pl. 7, figs. 15-17.

Type material. - Holotype, USNM 94449. Lower part of the Nevada Formation; Lone Mountain, Eureka County, Nev. This is the only known specimen of Eurekaphyllum.

Diagnosis.-See generic diagnosis.

Transverse section.-Septa number about 64 ; all are considerably withdrawn from the axis; minor septa, if distinguishable, exceed half the length of the major septa. Septa of the cardinal quadrants are thickened. Some septa extend discontinuously to the outer wall as thin crests. Width of the dissepimentarium is about equal to the length of the major septa; most dissepiments are very large, irregular and nonuniform; the longest extends one-fourth of the circumference. Fossula is indistinct.

Longitudinal section.-Tabulae are few; some are complete, the more nearly complete are widely separated and have a pronounced U-shaped sag with a 
somewhat flattened axial-periaxial segment. Large dissepiments of irregular form are in one or two columns.

Occurrence.-Lower part of the Nevada Formation, Lone Mountain, Eureka County, Nev. The horizon from which this form came is unknown; it probably came from unit 1 , coral zone $\mathrm{C}$, which is the zone in which Papiliophyllum is the abundant rugose coral.

Hill (1956, p. F273-F274) regards Eurekaphyllum as a junior synonym of Papiliophyllum. Study of a very large suite of specimens shows that the Eurekaphyllum structure is not normal or modal for the type of coral here placed in Papiliophyllum. As no additional representatives of Eurekaphyllum have been collected from the beds which probably yielded the type and only specimen, it seems likely that this form may be an aberrant and uncommon development from the Papiliophyllum stock. There are no intergradational forms, morphologically speaking. Without knowledge of the exact horizon or zone from which the type came, it is believed desirable to let the genus in question stand for the present. Like Kobeha it could well be found to have stratigraphic as well as morphologic significance.

\section{Family BETHANYPHYLLIDAE Stumm, 1949}

Reference form.-Bethanyphyllum robustum (Hall) 1876. Middle Devonian, New York.

Medium and large trochoid to ceratoid rugose corals with long, thin major septa and a cardinal fossula. Multiple columns of medium to small normal globose dissepiments occur in a wide dissepimentarium. Tabularium is medium or wide, consisting of combinations of straight, nearly complete tabulae and tabellae. Septa of the cardinal quadrants are unthickened beyond the nepionic stages.

Bethanyphyllidae may have sporadic zigzag carinae, but these are uncommon; in some species the fossula is weakly developed. The dissepimentarium-tabularium margin is usually not sharply defined. No lonsdaleioid dissepiments are known.

This family designation is appropriate for a stratigraphically important early Middle Devonian coral group possibly evolving from the ancestral stock of the Halliidae which precede Bethanyphyllidae in the Devonian of the Great Basin.

In a recent revision, the Family Bethanyphyllidae has been abandoned, Bethanyphyllum being assigned to the Zaphrentidae, together with Heliophyllum (Stumm, 1963, p. 139; 1964, p. 38). Pedder (1965, p. 207) has emended the Bethanyphyllidae to accommodate Bethanyphyllum, Ceratophyllum, Moravophyllum, Tortophyllum, and Stathmoelasma. In these genera, septa are smooth or weakly carinate, unlike Heliophyllum which has strong yardarm carinae. The car- dinal septum is relatively short. In mature stages it is difficult to recognize the cardinal fossula of some species; this is one of several features which distinguishes Bethanyphyllidae from Halliidae.

\section{Genus BETHANYPHYLIUM Stumm, 1949}

1876. Cyathophyllum robustum Hall, pl. 22, figs. 1-14.

1937. Cyathophyllum? lonense Stumm, p. 435, pl. 55, figs. 3a-b.

1937. Grypophyllum giganteum Stumm, p. 433, pl. 54, figs. 9a-b.

1937. Grypophyllum curviseptatum Stumm, p. 433, pl. 55, figs. 2a-b.

1937. Grypophyllum nevadense Stumm, p. 432, pl. 53, fig. 9, pl. 55, figs. 1a-b.

1937. Tabulophyllum nevadense Stumm, p. 434, pl. 55, figs. 4a-b.

1949. Bethanyphyllum Stumm, p. 18, pl. 8, figs. 1-4.

1956. Bethanyphyllum Hill, p. F278, figs. 189-6a-b.

1963. Bethanyphyllum Stumm, p. 139.

1965. (?) Stathmoelasma Pedder, pl. 31, figs. 1-5.

Type species.-Cyathophyllum robustum Hall, 1876, by original designation. Middle Devonian; Hamilton Group of western New York State.

Diagnosis.-Medium to large solitary trochoid to cylindrical rugose corals have numerous long, thin, usually fairly smooth septa. The longer septa reach the axis. Cardinal fossula is well defined to weak, without pronounced pinnate arrangement of several bordering septa. The dissepimentarium is wide, with multiple columns of steeply inclined mostly small dissepiments. The tabularium is wide or medium wide, consisting of a variable complex of partial to nearly complete, straight or bowed tabulae that are peripherally bordered by large tabellae passing into dissepiments laterally. Conspicuous vertical gaps commonly separate the tabluae. Outer wall is thin, lacking a peripherally continuous septal stereozone.

Remarks.-Bethanyphyllum lacks the more evident bilateral arrangement of septa characterizing Aulacophyllum and usually has no axial whorl like Tortophyllum. Some species assigned to Bethanyphyllum have septal thickening in the initial cardinal quadrant which persists well into the neanic stages (B. antelopensis). In mature stages, however, the septa of Bethanyphyllum are normally unthickened in cardinal quadrants alone, one of several features which distinguish this genus from the Papiliophyllum stock. If there is septal thickening in the late stages of Bethanyphyllum, it affects especially the axial parts of major septa in any or all quadrants. Bethanyphyllum also lacks the large lonsdaleioid dissepiments of Papiliophyllum. Carinae are absent in most species of Bethany phyllum; those species that do have scattered carinae, like $B$. antelopensis, are small and of the zigzag thickening type rather than the true yardarm carinae. 
Stathmoelasma, recently described by Pedder (1965, p. 207, pl. 31, figs. 1-5, pl. 32, fig. 10) from the Australian Devonian, is similar to Bethanyphyllum, of which it may be a synonym. Pedder's figures show indications of a weak fossula, and the longitudinal sections reveal nearly complete straight to slightly bowed tabulae like those of Bethanyphyllum, with conspicuous gaps. There is no septal stereozone.

Bethanyphyllum of coral zone $\mathrm{D}_{2}$ is preceded by Papiliophyllum of coral zone $\mathrm{C}$, which ranges up into coral zone $D_{1}$; Papiliophyllum has not been found in association with the more typical Bethanyphyllum, as exemplified by $B$. lonense (Stumm). However, in coral zone $\mathrm{D}_{1}$ Papiliophyllum individuals with intermediate features occur with advanced; these individuals reveal minor mature septal thickening in the cardinal quadrant and in some specimens a few rather inconspicuous lonsdaleioid dissepiments are present. Whereas these specimens suggest development toward Bethanyphyllum, they appear on the whole to be somewhat closer to the Papiliophyllum stock.

Bethanyphyllum lonense (Stumm)

Plate 11, figures 1-4; plate 12, figures 3-10

1937. Cyathophyllum? lonense Stumm, p. 435, pl. 55, figs. 3a, b.

Tabulophyllum nevadense Stumm, p. 434, pl. 55, figs. 4a, b.

1940. Cyathophyllum sp. Merriam, pl. 12, figs. 2, 4.

Type material. - Holotype, USNM 94453; lower part of the Nevada Formation, Lone Mountain, Eureka County, Nev.

Diagnosis. - Bethanyphyllum has thin, commonly rather wavy septa which may be slightly thickened toward the axis. Tabulae varying from straight, wide, and nearly complete to large and small tabellae. More continuous straight tabulae and larger tabellae bound the bigger longitudinal gaps. The dissepimentarium has several columns of rather small and steeply inclined dissepiments. The fossula is generally unrecognizable in mature growth stages.

External features.-Poorly known. This form seemingly does not become very large and tends to remain trochoid with a very deep calice.

Transverse sections.-Major septa of the advanced growth stages average 36 , some of which approach or reach the axis in mature sections. Minor septa are usually less than half the radius. Septa are thin and wavy, never entirely smooth, with abrupt angular bends. Some septa may be slightly thickened axially, where they may be contorted but not twisted to form an axial whorl. Between septa, the dissepiment traces and tabellar intersections are concentric and either evenly concave axially or occur as chevrons. The outer wall is thin, without appreciable stereoplasmic thick- ening. Neanic and ephebic sections show no fossula or cardinal septum. No nepionic or early neanic sections are available, but presumably the septa of cardinal quadrants are thickened, to judge from the related species Bethanyphyllum antelopensis.

Longitudinal sections. - The tabulariums of ephebic stages vary considerably in width within the corallum; they usually exceed half the diameter. The presence of a few straight, wide, and nearly continuous tabulae is characteristic, these tabulae separate longitudinal intervals of tabellae and shorter tabulae and define larger vertical gaps. Dissepiments, mostly small and globose, are disposed in numerous columns bounded axially by larger, less globose dissepiments or peripheral tabellae.

Comparison with related forms. - Bethanyphyllum lonensis differs from $B$. antelopensis in having a wider tabularium and shorter minor septa; major septa are more sinuous in $B$. lonensis. Some mature individuals of $B$. antelopensis have a cardinal fossula not observed in lonensis. B. robustum (Hall) differs in having a weakly defined ephebic cardinal fossula, more even septa, and relatively larger peripheral dissepiments.

Measurements of Bethanyphyllum lonense Stumm

\begin{tabular}{|c|c|c|c|}
\hline \multirow[b]{2}{*}{$\begin{array}{c}\text { Figured } \\
\text { specimen }\end{array}$} & \multirow[b]{2}{*}{$\begin{array}{c}\text { USNM } \\
\text { No. }\end{array}$} & \multicolumn{2}{|c|}{ Ephebic section } \\
\hline & & $\underset{(\mathrm{mm})}{\text { Diameter }}$ & $\underset{\text { septa }}{\text { Number of }}$ \\
\hline $\begin{array}{l}\mathbf{1} \\
2\end{array}$ & $\begin{array}{r}159272 \\
159273 \\
.159277 \\
.159278 \\
159278\end{array}$ & $\begin{array}{c}30 \\
24 \\
31.5 \\
124 \\
13\end{array}$ & $\begin{array}{r}40 \\
34 \\
38 \\
134 \\
26\end{array}$ \\
\hline
\end{tabular}

'Early ephebic.

Occurrence.-Nevada Formation, unit 2. Devonian coral zone $\mathrm{D}_{2}$; in association with Siphonophrentis (Breviphrentis) invaginatus. Lone Mountain: locality 58 (Merriam, 1940), localities M55, M1036, M1048. Northern Roberts Mountains: locality 11 (Merriam, 1940). Southern Sulphur Spring Range: locality M1047. Northern Fish Creek Range, Grays Canyon: localities M3, M51.

Bethanyphyllum antelopensis n. sp.

Plate 10, figures 1-7; plate 11, figures 5, 6; plate 12, figure 11

Type material. - Holotype, USNM 159265; paratypes, USNM 159266-159269, 159274. Lower part of the Nevada Formation, Combs Peak area, Eureka County, Nev.

Diagnosis.-This Bethanyphyllum has long major septa, commonly about two-thirds as long as the major septa, usually with a correspondingly wide dissepimentarium, and with several axially-periaxially straight tabulae separated by wide vertical gaps. The septa are thin except for the axial part which may be somewhat 
thickened; septa show only moderate waviness or irregularity. A fossula is present in some mature individuals.

External features.-Inadequately known.

Transverse sections.-Major septa average about 38 in mature sections. Septa are thin, only slightly wavy, and for the greater part approach the axis toward which they may be slightly thickened, especially in the cardinal quadrants. Minor septa are long, in some sections two-thirds the length of major septa. In some specimens, a fossula may be defined by a bending of pairs of septa at their axial ends toward the symmetry plane of the cardinal septum, which, if correctly identified, remains fairly long in mature stages. Dissepiments between septa appear to be axially concave, and chevron features make a concentric pattern. Outer wall appears to be thin and without stereozone. Septa of cardinal quadrants are very much thickened and in lateral contact through to mid-neanic stages. One neanic section with 30 major septa shows thick cardinal quadrant septa laterally in contact except near the alar positions; the cardinal septa are arranged on either side of a somewhat shortened cardinal septum. Major septa are withdrawn slightly from the axis. Within the tabularium, the counter quadrant septa are also thickened slightly. There are rows of concentric dissepiments in the counter quadrants, but none were recognized in the cardinal quadrants. Minor septa are slightly less than half the length of the majors. The wall is unthickened by stereoplasm.

Longitudinal sections. - The tabularium, usually rather narrow, ranges from one-fourth to nearly onehalf the corallite diameter in the mature growth stages. Nearly straight, almost complete tabulae define vertical intervals separated by intervals of less complete tabulae and peripheral tabellae. The more complete straight tabulae commonly occur where the vertical separation is greater. Dissepimentarium has numerous columns of steeply inclined, small to medium and large dissepiments, of which the smaller predominate.

Comparison with related forms.-See Bethanyphyllum lonense.

Measurements of Bethanyphyllum antelopensis n. sp.

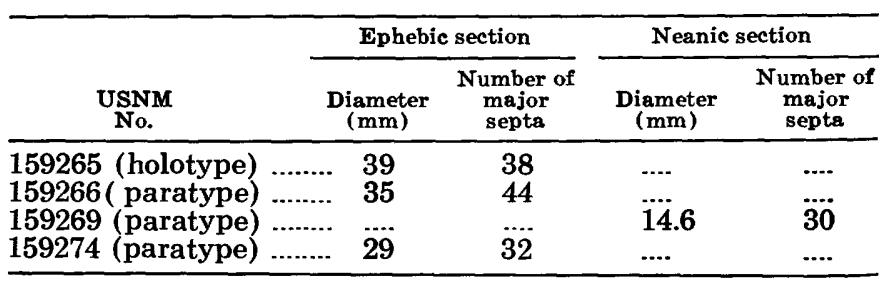

Occurrence.-Lower part of the Nevada Formation, unit 2; Middle Devonian, Devonian coral zone $\mathrm{D}_{2}$. Locality M27, 1.75 miles south of Combs Peak at a horizon about 270 feet stratigraphically above the base of the Nevada Formation and just below a 15-foot quartzite bed of Oxyoke Canyon type. The associated fauna of the Spirifer pinyonensis zone includes abundant "Martinia" undifera.

Similar corals provisionally assigned to $B$. antelopensis (pl. 11, figs. 7-9) occur at Lone Mountain (locality M1045) in the upper part of unit 2, possibly as high as Devonian coral zone $D_{3}$

\section{Bethanyphyllum sp. d}

Plate 10, figures 8-10; plate 13, figures 6, 7, 9

Figured specimens.-USNM 159270, 159271, 159281, 159281a. Lower part of the Nevada Formation, Lone Mountain, Eureka County, Nev.

Specimens classified as Bethanyphyllum sp. d differ from $B$. lonense and $B$. antelopensis in features of the tabularium; they are wider, and the tabulae are more closely spaced with a tendency toward distal arching. The wide vertical gaps between some tabulae of lonense and antelopensis were not found in $\mathrm{sp}$. $\mathrm{d}$. It is probable that $\mathrm{sp}$. $d$ lacks the very deep calice of some individuals of lonense.

Occurrence.-Lower part of the Nevada Formation, lower beds of unit 2; Devonian coral zone $D_{1}$. Lone M ountain, locality M1037, where it occurs with the fa una including the advanced Papiliophyllum elegantulum subsp. d.

\section{Family CHONOPHYLLIDAE Holmes, 1887}

Reference form.-Chonophyllum Edwards and Haime, 1850.

These solitary rugose corals are of medium to large size, dissepiments partly or wholly lonsdaleioid; some tabulae are complete, flat or domed. Major septa are lamellar, elongate, discontinuous peripherally, little thickened. Fossula is weak or absent.

Genera included in this family are as follows:

Chonophyllum Edwards and Haime, 1850

Ketophyllum Wedekind, 1927

Tabulophyllum Fenton and Fenton, 1924

Sinospongophyllum Yoh, 1937

Diversophyllum Sloss, 1939

The Chonophyllidae are commonly quite rugate externally because of their numerous rejuvenescence flanges and cone-in-cone growth habit. The septal stereozone is usually not a conspicuous feature, and the tabularium ranges from narrow in Chonophyllum to wide or very wide in the other genera.

\section{Genus SINOSPONGOPHYLLUM Yoh, 1937}

1937. Sinospongophyllum planotabulatum Yoh, p. 56, pl. vi, figs. 2-5.

1940. Sinospongophyllum Yoh. Lang, Smith, and Thomas, p. 119.

1949. Tabulophyllum Stumm, p. 27 (in part); pl. 12, figs. 20, 21. 
1956. Sinospongophyllum Yoh. Hill, p. F300, fig. 204, 5a-b.

Type species.-Sinospongophyllum planotabulatum Yoh (by original designation). Upper part of the middle Devonian; Kwangsi, China.

Diagnosis. - This ceratoid to subcylindrical Chonophyllidae has rather closely spaced, wide to very wide tabulae which are either straight or sag axially and peripherally. Septa are amplexoid, smooth or minutely wavy, noncarinate, and usually withdrawn from axis. Minor septa are well defined. Peripheral zone has septal crests, large irregularly distributed lonsdaleoid dissepiments, and smaller normal dissepiments. Septal stereozone is narrow to moderately wide. Fossula is weak or absent.

Remarks.-Yoh's figures and the type show very steeply inclined dissepiments in a rather narrow band, very wide, flattened tabulae, and no fossula.

Diversophyllum (Sloss, 1939, p. 65) differs in having longer septa that reach the axis, more arched and irregular tabulae, and less tendency to produce lonsdaleioid dissepiments.

Tabulophyllum, as typified by the Upper Devonian T. rectum, differs from Middle Devonian Sinospongophyllum in having weakly developed minor septa and a less evident septal stereozone. However, the two genera have much in common, and Sinospongophyllum is regarded by Stumm (1949, p. 27) as a possible synonym. For the present, however, it seems desirable to retain Sinospongophyllum, pending more thin section study of topotype material of both species. Externally the eleven described Iowa Late Devonian species of Tabulophyllum (Fenton and Fenton, 1924) show a great variety of form, from turbinate to subcylindrical, and some with wide dissepimentarium.

In the Cordilleran belt, corals assignable to either Sinospongophyllum or Tabulophyllum are characteristic of late Middle and Late Devonian rocks in the Great Basin, southeast Alaska, and northwest Canada (Smith, 1945). They occupy Great Basin late Middle Devonian coral zone $\mathrm{F}$ in association with Hexagonaria. Those corals of lowermost Middle Devonian coral zone D that are placed in Sinospongophyllum have a very wide tabularium, and some specimens have only a few sporadic lonsdaleioid dissepiments. These coral zone D specimens occur with Siphonophrentis (Breviphrentis) invaginatus, variants of which they resemble. Stumm's (1949, p. 25) Breviphyllum that was founded upon Nevada Formation material was possibly inspired by examination of such associated material; the holotype is seemingly without dissepiments and probably represents a specimen of invaginatus. Possibly such sparingly dissepimented zone D corals may be derived from the Breviphrentis invaginatus stock by the aberrant development of dissepiments.
At present they are insufficiently known for specific description and accordingly are designated informally by letter.

\section{Sinospongophyllum sp. d \\ Plate 17, figures 1, 2, 5, 6}

Figured specimens.-USNM 159312, 159314; lower part of the Nevada Formation, Lone Mountain and northern Antelope Range, Eureka County, Nev.

The lonsdaleioid dissepiments are large, elongate, and irregularly distributed in one or two columns. The tabulae are closely spaced. The septal stereozone is narrow.

Occurrence.-Late Early Devonian, coral zone $\mathbf{D}_{1}$. Locality M1037, south pediment of Lone Mountain, Eureka County, Nev. Early Middle Devonian, coral zone $\mathrm{D}_{2}$. Locality M1035, north end Antelope Range, southern Eureka County, Nev.

\section{Sinospongophyllum sp. e \\ Plate 17, figures 3, 4, 10, 11}

1937. (?) Amplexus nevadensis Stumm, p. 427, pl. 54, figs. 3a-c. 1937. (?) Amplexus magnus Stumm, p. 428, pl. 54, figs. 5a-b.

Figured specimens.-USNM 159313, 159317; lower part of the Nevada Formation, Lone Mountain and northern Antelope Range, Eureka County, Nev.

The lonsdaleioid dissepiments are small and irregularly distributed in one to several columns. The tabulae are closely spaced. The septal stereozone is narrow. Major septa are withdrawn from the axis.

Occurrence.-Early Middle Devonian, coral zone $\mathrm{D}_{2}$. LocalityM1038, Lone Mountain, Eureka County, Nev. Locality M1035, north end Antelope Range, southern Eureka County, Nev.

\section{Sinospongophyllum sp. 1 \\ Plate 17, figures 7, 8, 9}

Figured specimens.-USNM 159315, 159316; lower part of the Nevada Formation, Grays Canyon and northern Antelope Range, Eureka County, Nev.

The lonsdaleioid dissepiments are small and irregularly distributed in one to several columns. The tabulae are closely spaced. The septal stereozone is narrow to fairly wide. Major septa extend to the axis where they are twisted together in an axial plexus.

Occurrence.-Early Middle Devonian, coral zone $\mathrm{D}_{2}$. Locality M3, Grays Canyon, southern Eureka district, Nev.: Locality M1035, north end Antelope Range, southern Eureka County, Nev.

\section{Family ENDOPHYLLIDAE Torley, 1933}

Reference forms. - Endophyllum bowerbanki Edwards and Haime and $E$. abditum Edwards and Haime, 1851. Devonian; Torquay, England.

These cerioid and aphroid rugose corals have wide 
corallites, a broad marginarium of partly large lonsdaleioid dissepiments and a narrow to very wide tabularium comprising closely spaced tabulae. There is no axial structure.

Genera provisonally assigned to the Endophyllidae are Endophyllum Edwards and Haime, 1851, Yassia Jones, 1930, and Australophyllum Stumm, 1949. Undescribed Late Silurian corals in the Great Basin and the Klamath Mountains are related to Australophyllum; the Klamath forms are a separate genus, and those of the Great Basin a subgenus of Australophyllum.

Some corals here regarded as Endophyllidae have previously been assigned to Spongophyllum, a genus not included in this family. It is proposed that the term Spongophyllum be applied to species with slender corallites agreeing in general structure and proportions with the Devonian S. sedgwicki as originally illustrated by Edwards and Haime (1853, pl. 56, figs. 2, 2a-c, 2e).

In addition to the wide lonsdaleioid marginarium, Late Silurian representatives of Yassia and a subgenus of Australophyllum manifest a decided tendency to abbreviate and lose septa in mature growth stages. These characteristics are not observed in Spongophyllum.

\section{Genus AUSTRALOPHYLLUM Stumm, 1949}

1911. Spongophyllum cyathophylloides Etheridge, p. 7-8, pl. A, fig. 3, pl. C, figs. 1-2.

1949. Australophyllum Stumm, p. 34, pl. 16, figs. 1-2.

1956. (?) Australophyllum cyathophylloides (Etheridge). Hill, fig. 207-4a-b.

Type species. - Spongophyllum cyathophylloides Etheridge; by author designation. "Lower Middle Devonian"; Douglas Creek, Clermont, Queensland, Australia.

Diagnosis. - The cerioid Endophyllidae have medium wide to narrow, closely spaced, proximally sagging tabulae. The wide to very wide dissepimentarium has scattered to wholly lonsdaleioid dissepiments, some of which are large.

Remarks. - Australophyllum differs from Spongophyllum in possessing multiple columns of elongate, lonsdaleioid dissepiments, and more closely spaced sagging tabulae which lack a peripheral depression. Stumm's diagnosis of Australophyllum includes carinate septa, although his figures do not show these convincingly. The wall of typical Australophyllum is somewhat thickened stereoplasmically; septal crests do not appear to be characteristic, as they are in the Silurian subgenus.

Australophyllum landerensis n. sp.

Plate 25, figures 1-4

Type material.-Holotype, USNM 159353; para- type, USNM 159354. Lower Devonian Rabbit Hill Limestone, Toquima Range, locality M1150.

Diagnosis.-This Australophyllum has long minor septa; all septa are thickened in the tabularium. The outer dissepiments are steeply inclined for the genus; the outer wall is thickened and beaded with wall crests. The tabularium is medium wide; close-set tabulae have a pronounced sag.

External features.-Occurs in compact ceriod heads up to $15 \mathrm{~cm}$ or more in diameter.

Transverse sections.-Septa are about 44, all of which are long and usually thickened within the tabularium; minor septa are more than one-half the length of major septa. Some major septa reach the axis where they are twisted. Some septa may be minutely wavy and, where thickened, show minute nodes and lateral bumps, but there are no true elbow carinae. The stereome-thickened wall has a beaded appearance because of the wall crests; other septal crests are sparse in the lonsdaleioid band.

Longitudinal sections.-The tabularium, about onethird the corallite width at maturity, is very sharply set off from the dissepimentarium. The tabulae, 4 or 5 per millimeter, have a pronounced sag which may be angulate axially. Large outer dissepiments are steep for this genus; the smaller ones become vertical at the tabularium margin. Dissepiment columns range from 7 to 12. Thickened axial segments of major septa reveal minute lateral bumps.

Reproductive offsets.-One mature corallite shows three calice wall offsets internally situated.

Fine structure.-Some thickened septa may have a median clear trace; trabecular structure and lamination are poorly defined in the septal stereozone.

Comparison with related forms.-Australophyllum cyathophylloides, the type species, differs in having fewer septa which lack thickening in the tabularium. Australophyllum sp. (plate 25, fig. 5) from the upper part of the Vaughn Gulch Limestone, Owens Valley, Calif. (locality M1093), resembles landerensis but lacks the thickened septa. The Vaughn Gulch form occurs in beds of Late Silurian or Early Devonian age that are immediately above the Late Silurian coral zone $\mathrm{E}$ which contains an Australophyllum so different that it is placed in a new subgenus. The form from Silurian coral zone $\mathrm{E}$ has broader mature corallites with a considerably smaller septal count and lacks septal thickening; this form has outer lonsdaleioid dissepiments inclined at a low angle, a larger number of very large dissepiments and, unlike landerensis, tends to reduce and lose septa at maturity.

Measurements. - Mature corallite diameter and septum count: 


\begin{tabular}{|c|c|c|c|c|c|}
\hline \multirow[b]{2}{*}{ Corallite } & \multicolumn{3}{|c|}{$\begin{array}{c}\text { Holotype } \\
\text { USNM 159s5s }\end{array}$} & \multicolumn{2}{|c|}{$\begin{array}{c}\text { Paratype } \\
\text { USNM 159954 }\end{array}$} \\
\hline & A & B & C & A & B \\
\hline ter (in $\mathrm{mm}$ ) & 13 & 14 & 10 & 13 & 10 \\
\hline $\mathbf{M a j}$ & .22 & 22 & 22 & 20 & 22 \\
\hline
\end{tabular}

Occurrence.-Lower Devonian Rabbit Hill Limestone, Petes Canyon, locality M1150 at north end of Toquima Range, southern Lander County, Nev. At locality M1150 this colonial coral is associated with a typical Rabbit Hill fauna like that of the type locality. Colonial corals of this kind are uncommon in the Rabbit Hill Limestone, which usually contains only the small solitary rugose coral Syringaxon.

\section{Family DISPHYLLIDAE Hill, 1939}

Reference form.-Disphyllum caespitosum (Goldfuss), 1826. Middle Devonian, Germany.

These phaceloid, cerioid, thamnastraeoid, and aphroid rugose corals have smooth or carinate, continuous lamellar, and usually little-dilated septa. The tabularium is wide, combining straight and slightly domed tabulae with marginal tabellae. Dissepiments in several columns are normal-globose or elongate; rarely lonsdaleioid. There are no horseshoe dissepiments. Species with a wide dissepimentarium have bases of outer dissepiments nearly horizontal.

This large complex Devonian family includes the following genera and subgenera:

Disphyllum de Fromentel, 1861

Cylindrophyllum Simpson, 1900

Acinophyllum McLaren, 1959

Hexagonaria Gürich, 1896

Hexagonaria (Pinyonastraea) new subgenus

Billingsastraea Grabau, 1917

Taimyrophyllum Chernychev, 1941

Aphroidophyllum Lenz, 1961

Cerioid Hexagonaria-like genera are common in the Silurian and Devonian; most of these do not fit well in this family. Among these are the Australian Xystriphyllum Hill with wedge-thickened smooth septa and a narrow dissepimentarium and Columnaria-like species with few and irregularly distributed dissepiment columns of the German Devonian (Glinski, 1955). Certain other European Devonian species assigned to Hexagonaria appear to be affiliates of the Family Phillipsastraeidae (Rozkowska, 1960; Moenke, 1954).

The true spongophyllids and the Endophyllidae, which include Endophyllum and Australophyllum, are distinguished by a lonsdaleioid marginarium. However, this type of dissepiment arose independently in several rugosan families and may be expected to appear sporadically in Hexagonaria and other disphyllid genera.

The Family Phillipsastraeidae as here interpreted does not include the disphyllid corals (Hill, 1956, p. F279-F282; Stumm, 1964). Phillipsastraeidae are characterized by highly distinctive internal features such as columns of true horseshoe dissepiments with contiguous peculiar trabecular bundles or sheaves. Moreover, in the Great Basin stratigraphic column the disphyllid forms are older, occurring in coral zones $\mathrm{D}_{2}$ and $\mathrm{F}$; the true Phillipsastraeidae are of Late Devonian age, present only in coral zone I.

Genus DISPHYLLUM Fromentel, 1861

1826. Cyathophyllum caespitosum Goldfuss, p. 60, pl. XIX, fig. 2b only; not pl. XIX, figs. 2a, 2c, $2 d$.

1846. Cladocora goldfussi Geinitz (in part), p. 569. New name for Cyathophyllum caespitosum Goldfuss, 1826, p. 60, pl. XIX, figs. 2a-d; not pl. XIII, fig. 4.

1935. Cyathophyllum caespitosum Goldfuss 1826 (p. 60, pl. XIX, fig. 2b only). Lang and Smith, p. 545.

1940. Disphyllum de Fromentel. Lang, Smith, and Thomas, p. 53.

1945. Disphyllum Fromentel. Smith, p. 20-21 (in part only). 1949. Disphyllum de Fromentel. Stumm, p. 32, pl. 15, figs. 1-5.

1956. Disphyllum de Fromentel. Hill, p. F280, fig. 191-10a-b.

Type species.-Cyathophyllum caespitosum Goldfuss, 1826, p. 60, pl. XIX, fig. $2 b$ only (Lang and Smith, 1935 , p. 545 ; Smith, 1945 , p. 20-21). Middle Devonian; Eifel district, Germany. Details of the complex taxonomic history relating to this type fixing are reviewed by Lang and Smith (1935, p. 545; Lang, Smith, and Thomas, 1940, p. 53; and Smith, 1945, p. 20-21).

Diagnosis.-These bushy and phaceloid rugose corals have fairly long slightly thickened major septa which do not reach the axis; minor septa are over half the length of the major septa. The tabularium is medium to wide; most tabulae are continuous and fairly straight, may be complete in some specimens and commonly are in combinations with periaxial tabellae. There may be a minor circular sag at the periphery of the tabularium, but not a pronounced uparching or axial sag. The dissepimentarium has several columns of small to medium dissepiments; the peripheral dissepiments are nearly flat, but the axial ones steepen to vertical in a border zone of small dissepiments. Large dissepiments are uncommon; there are no true lonsdaleioid dissepiments. Some septa may have zigzag carinae, but these are uncommon; there are no yardarm carinae.

Remarks.-Disphyllum is here interpreted according to illustrations of the type species of Smith (1945, pl. 11, figs. 8a-c) and of Stumm (1949, pl. 15, figs. 1-5). Acinophyllum McLaren (1959, p. 2228) has a narrower dissepimentarium and wider, straighter tabulae without marginal tabellae. Some other phaceloid rugose corals which might be confused with Disphyllum have marginal horseshoe dissepiments; these include Phacellophyllum Gürich and Peneckiella Soshkina, possibly a synonym of Phacellophyllum (see 
McLaren, 1959, p. 22-23; p. 28-29). Cylindrophyllum Simpson has yardarm carinae; Eridophyllum has carinate septa and an aulos. Sociophyllum, which is the commoner coral of this general type in the Nevada Formation, has a wide peripheral zone of lonsdaleioid dissipiments and lacks carinae.

\section{Disphyllum nevadense (Stumm), 1937 Plate 18, figures $7-10$}

1937. Spongophyllum nevadense Stumm, p. 435, pl. 53, fig. 10, pl. 55, figs. 5a, b.

(?) Spongophyllum expansum Stumm, p. 436, pl. 53, fig. 11 , pl. 55, figs. $6 a$, b.

1940. not Spongophyllum cf. expansum Stumm. Merriam, p. 56-57.

not Disphyllum nevadense Stumm, p. 63.

Type material.- Holotype, USNM 94454; lower part of the Nevada Formation, Lone Mountain, Eureka County, Nev.

Diagnosis.-This slender Disphyllum has few dissepiment columns, including both globose and narrow elongate dissepiments; large, elongate dissepiments are interseptal and not lonsdaleioid.

Transverse section.-Major septa, 16 to 18 , extend to the axis in many corallites. Minor septa vary from short to more than half the length of the major septa. Septa, thin and wavy or straight, are more inclined to waviness in the tabularium; they are noncarinate. The wall is thin and lacks a stereozone.

Longitudinal section.-The dissepiment columns range from one to three. The dissepiments are either small and globose or elongate. In places a nearly flat, elongate dissepiment extends from the periphery to the tabularium. Commonly there are one or two small nearly vertical dissepiments at the inner margin. The tabularium is wide; tabulae, mostly continuous or complete, are usually uparched distally with a periaxial sag; they are rarely straight.

Reproductive offsets.-Lateral offsets are developed at the calice periphery to form branches.

Comparison with related forms.-Disphyllum eurekaensis $\mathrm{n}$. sp. has larger corallites with zigzag carinate septa and many more dissepiment columns lacking the elongate individual dissepiments. Disphyllum goldfussi (Geinitz) has more small dissepiment columns and lacks the elongate dissepiments of $D$. nevadense.

Remarks.-Disphyllum nevadense Stumm, (1940) is a Late Devonian species of coral zone $I$ and not closely related to the form here reassigned to Disphyllum.

Measurements.-Diameter and major septa, three corallites of colony USNM 159320:

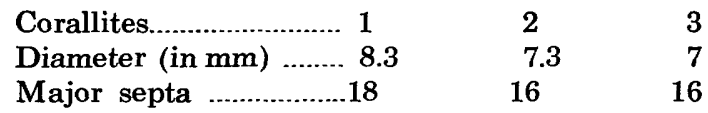

Occurrence.-Nevada Formation, unit 2. Devonian coral zone $\mathrm{D}_{2}$. Lone Mountain: Eureka County, Nev. locality M1046; at this locality it is associated with Disphyllum eurekaensis $\mathrm{n} . \mathrm{sp}$.

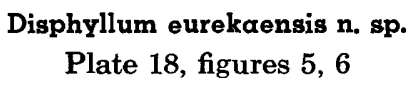

Type material.-Holotype, USNM 159319. Nevada Formation, unit 2; Devonian coral zone $\mathrm{D}_{2}$. Lone Mountain locality M1046.

Diagnosis.-This Disphyllum has corallites of large diameter and multiple columns of predominantly small dissepiments. The tabulae are mostly wide and fairly straight; some specimens are complete and some have peripheral tabellae and a tendency for peripheral depression of tabulae. The septa are slightly thickened in the dissepimentarium; some have weak zigzag carinae.

External features.- Longitudinal grooves are not well shown; in places transverse rugae are fairly pronounced. There are lateral mergings of corallites in positions of marginal calicinal offsets.

Transverse sections.-Major septa, which number 18 to 22 do not reach the axis; minor septa are about two-thirds the length of the major septa. The septa are minutely wavy to zigzag and have sporadic zigzag carinae in the middle part of the dissepimentarium. Outer dissepiments are rather irregular; some are concave peripherally. All septa are continuous to the wall. The wall is thin and lacks a stereozone. Some are thickened slightly toward the inner edge of the dissepimentarium.

Longitudinal sections. - Dissepiments, small and medium size, are in as many as eight columns on each side; outer three or four columns are medium, globose, and nearly flat to low dipping axially; inner four columns are small and steep to vertical. There are some large elongate dissepiments in the outer zone. The tabulae are rather closely set and for the most part fairly continuous and straight; some are complete, with large periaxial tabellae. Peripheral parts of the tabulae are depressed in some specimens. Traces of carinae appear in local patches.

Reproductive offsets. - The merging of corallites laterally indicates reproductive offsets from calice margins.

Comparison with related forms.-Disphyllum eurekaensis differs from $D$. goldfussi (Geinitz) in having more wavy and partly zigzag, weakly carinate septa; the tabularium of $D$. goldfussi (see Smith, 1945, pl. 11, figs. 8a-c; Stumm, 1949, pl. 15, figs. 2-3) is wider with more tabellae at the tabularium margin. Disphyllum nevadense (Stumm, 1937) has narrower corallites lacking the zigzag carinae, fewer dissepiment columns, 
and partly elongate dissepiments. Disphyllum nevadense Stumm (1940, p. 63, pl. 7, fig. 10; pl. 8, figs. 11ab), a much younger species from the Devils Gate Limestone, is more slender, has fewer columns of dissepiments and a wide tabularium with medial flat tabellae, and lacks the more nearly complete straight tabulae of $D$. eurekaensis.

Measurements.-Diameter and major septa; three corallites of colony USNM 159319:

\begin{tabular}{|c|c|c|}
\hline orallites ......... & 1 & 2 \\
\hline Diameter (in $\mathrm{mm}$ ) & $\ldots 19$ & 16.6 \\
\hline Major septa &. .20 & 20 \\
\hline
\end{tabular}

Occurrence.-Nevada Formation, unit 2. Devonian coral zone $\mathrm{D}_{2}$. Lone Mountain: locality M1046, associated with D. nevadense (Stumm, 1937).

\section{Genus HEXAGONARIA Gürich, 1896}

1900. Prismatophyllum Simpson, p. 218.

Type species. - Cyathophyllum hexagonum Goldfuss; by subsequent designation (Lang and others, 1940, p. 69). Middle Devonian; Eifel district and Bensberg, Germany.

Diagnosis.-The colonies are spherical and mushroom shaped; the polygonal corallites are separated by a discrete, usually unthickened wall. Calices have a flat or axially sloping peripheral platform and a deep axial pit. Major septa are unbroken from the wall into the tabularium and commonly reaching the axis; minor septa end at tabularium margin. Septa are normally thin, modified by waviness, minor zigzag elbow carinae and strong yardarm carinae. Dissepimentarium, usually wide, has multiple columns in which peripheral dissepiments lie nearly flat. There are no horseshoe dissepiment columns and no associated trabecular bundles.

Remarks.-Most species of true Hexagonaria have long septa, some of which reach the axis. The septa commonly thin abruptly within the tabularium. There are, however, aberrant forms with all the septa shortened and an overly widened tabularium. The patterns of tabulae are usually irregular and include variable combinations of arched tabellae against inclined and incomplete tabulae; straight complete tabulae are unusual. Thickened walls and septa are uncommon, although there are species in which some individuals have moderate radially extended dilation or sporadic small bumpy or knobby swellings (Rozkowska, 1960, figs. 9, 11, 12).

Most species presently interpreted as Hexagonaria have carinae; usually yardarm carinae are in some but not all corallites or are restricted to parts of a single corallite. For example, Stumm's figures of the type species Hexagonaria hexagona Goldfuss from the Eifel district show definite and numerous yardarm carinae
(Stumm, 1948a, pl. VI, figs. 1, 2). However, Sorauf's (1967, p. 10, fig. 4) figures of a specimen assigned to hexagona from Frasnes, Belgium, reveal no clear indication of yardarm carinae. It is assumed that the Eifel district material from the Middle Devonian is more nearly representative of the Goldfuss type species.

Unrelated Hexagonaria-like Rugosa.-Any family of dissepimented rugose corals may theoretically give rise to compact cerioid species by adaptive radiation. Within the Phillipsastraeidae have evolved rather closely related solitary, bushy, and lastly cerioid forms which parallel Hexagonaria. Convergent or homeomorphic cerioid corals of this sort are known in Paleozoic strata from Silurian to Carboniferous. All share the compact growth habit, by itself not a feature of overriding taxonomic importance. Five of these families have cerioid radicles: (1) Kyphophyllidae, (2) Endophyllidae, (3) Spongophyllidae, (4) Disphyllidae, and (5) Phillipsastraeidae. Within a wide range of internal structure combinations, each family gave rise to lineages paralleling or mimicking Hexagonaria of the Disphyllidae.

Silurian rugose coral genera possessing the cerioid growth habit of Hexagonaria have received little attention from paleontologists. Undescribed corals from the Klamath Mountains Gazelle Formation possess a narrow, weakly developed tabularium and are classified with the Kyphophyllidae. Other western Silurian forms are endophyllids with strong lonsdaleioid dissepiments. Late Silurian Hexagonaria-like species of eastern North America are members of the cerioid genus Entelophylloides Rukhin, as are some Russian species.

Stratigraphic range of Hexagonaria.-Hexagonaria has been reported in Devonian rocks of western Europe as old as Emsian and Siegenian (Sorauf, 1967, p. 24). In general those species which are convincingly disphyllid appear in the Eifelian rocks. In Europe the highest known Hexagonaria is Frasnian Late Devonian. The Hexagonaria from the Great Basin appears as the subgenus Pinyonastraea in the Nevada Formation, unit 2 and coral zone $D_{2}$, probably in earliest Eifelian. True Hexagonaria peaks in coral zone $\mathbf{F}$, which is the higher Eifelian of this province. No coral zone I or Frasnian Hexagonaria is known with assurance in the Great Basin; all cerioid species of zone I thus far identified are Phillipsastraeidae.

Hexagonaria systematics. - Characters by which Hexagonaria may be subdivided taxonomically and distinguished from Phillipsastraeidae and other families have been reviewed by Stumm (1948a), Schouppé (1958), and more recently by Sorauf (1967). At present Hexagonaria is a large morphologically diverse and 
complex genus of worldwide distribution in need of descriptive study and taxonomic appraisal. Some morphologically similar taxa within its scope are doubtless products of convergent evolution. As with Billingsastraea and other disphyllids, it is not unlikely that similar internal structures developed in not very closely related genetic stocks; in this light Hexagonaria may be quite polyphyletic.

Current investigations of Hexagonaria differentiation in Great Basin Devonian coral zones D and F suggest that subgenera may be used appropriately. Accordingly the earliest Hexagonaria of coral zone $\mathrm{D}$ is discribed as subgenus Pinyonastraea.

Of uncertain relationship to Hexagonaria are three noncarinate Devonian groups of Hexagonaria-like corals: (1) the genus Xystriphyllum; (2) a group having a few small sporadic lonsdaleioid dissepiments; and (3) aberrant species structurally intermediate between Hexagonaria and Columaria.

Xystriphyllum, unlike Hexagonaria, has a thickened wall, thickened gradually wedge-tapering smooth septa, narrow tabulae, and very steeply inclined or vertical dissepiments. Group 2, with its scattered small lonsdaleioid features, may conceivably be a Hexagonaria derivative, for dissepiments of this kind clearly arose in numerous genetically unrelated lineages. Australophyllum of the Endophyllidae differs in possessing a well-defined lonsdaleioid band.

Group 3, a heterogeneous, probably polyphyletic form group, from the Devonian of Western Europe, comprises thick-walled species with a very wide tabulae, a reduced dissepimentarium having few columns, and thick wedge-tapering, commonly short septa (Glinski, 1955). Generic or subgeneric grouping may eventually prove appropriate for these local differentiates.

Certain Polish species of "Hexagonaria" described by Moenke (1954) appear, on examination of the published figures, to be better assigned to the Phillipsastraeidae. The origin of this family is unexplained. Whether the distinctive horseshoe dissepiment columns and trabecular bundles arose in a Middle Devonian disphyllid line can only be inferred at present. In the Central Great Basin, beds of coral zone F with Hexagonaria also contain disphyllids of the Taimyrophyllum type surficially mimicking Late Devonian (coral zone I) Pachyphyllum of the Phillipsastraeidae. These mimics lack the horseshoe dissepiment columns and trabecular bundles.

Study of Hexagonaria suites from coral zone F, supplemented by review of the literature on Disphyllidae, suggests that the following characters are of special taxonomic value within this and allied genera.
1. Septal configuration: thin, smooth and straight; or thickened, tapering gradually from wall; or wavy, zigzag with elbow carinae, yardarm carinae, or combination of these.

2. Wall in transverse section: thin and wavy or straight; or thickened stereoplasmically with obtusely wedge-tapering septum bases.

3. Width of tabularium relative to dissepimentarium.

4. Outer dissepiments in longitudinal section: vertical to steeply inclined toward axis; or nearly horizontal.

5. Outer dissepiments in transverse section: normal concentric, or irregular with herringbone pattern.

The width of the tabularium is a feature having a good deal of latitude within a species and between species. Normally about one-third the corallite diameter in most species, the tabularium may broaden to exceed one-half the corallite diameter, and the dissepiment band narrows correspondingly as the septa shorten. At the opposite extreme is Hexagonaria with narrow tabularium and thin axial septum extensions which meet in a twisted axial plexus accompanied by median uparching of tabulae. A small raised median calice boss may result, but no discrete axial rod or columella.

\section{Subgenus PINYONASTRAEA, new subgenus}

1937. Prismatophyllum kirki Stumm, p. 437; pl. 55, figs. 7a-b. 1940. "Prismatophyllum" kirki Stumm. Merriam, pl.16, fig. 5. Type species.-Prismatophyllum kirki Stumm, here designated. Nevada Formation, unit 2, Devonian coral zone $\mathrm{D}_{2}$; Lone Mountain.

Diagnosis.-This Hexagonaria has a thin wall and thin minutely wavy septa lacking yardarm carinae. The dissepimentarium is wide and has numerous columns of globose dissepiments; the peripheral dissepiments are nearly flat. The calice is shallow with a broad brim platform and an axial pit.

Remarks. - The subgenus Pinyonastraea differs from Hexagonaria (Hexagonaria) as typified by its type species hexagona Goldfuss (Stumm, 1948a, p. 11$15, \mathrm{pl}$. VI, flgs. 1-2) in lacking crossbar or yardarm carinae and other septal thickenings. Carinae, if developed in Pinyonastraea, are weak and of the zigzag elbow or angulation type.

Stumm, in 1937 (p. 437), called attention to this coral type as possibly having developed from ancestry different from that of other "Prismatophyllum." If it has, study of more adequate material might justify separate generic designation eventually.

Selected individuals of Pinyonastraea kirki resemble internally the associated Billingsastraea nevadensis, 
especially subspecies arachne; the principal difference is lack of the outer wall. As elsewhere noted, it is conceivable the two come from common ancestry.

Pinyonastraea is a relatively uncommon coral in the higher part of Nevada Formation, unit 2, unlike the local occurrence of Hexagonaria s.s. which is abundant in higher Middle Devonian coral zone F. The new subgenus has not been recognized outside of the Great Basin Province.

\section{Hexagonaria (Pinyonastraea) kirki (Stumm)}

Plate 23, figures 5-10

1937. Prismatophyllum kirki Stumm, p. 437, pl. 55, figs. 7a-b. 1940. "Prismatophyllum" kirki Stumm. Merriam, pl. 16, fig. 5. 1949. Hexagonaria kirki (Stumm), pl. 15, figs. 16, 17.

Type material.-Holotype USNM 94456; lower part of the Nevada Formation, Lone Mountain, Eureka County, Nev.

Diagnosis.-This Pinyonastraea has large corallites, minutely undulant, very weakly zigzag, thin carinate septa and thin, even, commonly straight walls. Some of the outer dissepiments are sublonsdaleioid in the peripheral irregular zone of the dissepimentarium.

External features.-This species occurs in large lenticular colonies $25 \mathrm{~cm}$ or more in greatest diameter. Individual corallites are considerably larger than average for Hexagonaria. A well-preserved distal surface (pl. 23 , fig. 7) shows shallow calicinal pits with a weak crateriform rim; the calicinal platform is concavely depressed to almost flat, and the thin outer wall stands sharply in relief.

Transverse sections.-Major septa number 20-23; these are uniformly thin, and for the greater part extend without discontinuity to the axial vicinity. Minor septa are more than half to nearly as long as the major septa, which extend to the tabularium margin. Some minor septa are discontinuous, represented by crests, or lacking; minor septa commonly do not pass peripherally to the wall. Septa range from straight and nearly smooth to minutely undulant and zigzag carinate. However, the carinae are not abundant; they are minute, and in some specimens confined to a few septa, in which they occur alternately in radial succession. There are no yardarm carinae. The peripheral zone of irregular dissepiments is wide; the outer sublonsdaleioid dissepiments, if present, usually are small.

Longitudinal sections.- The flat-lying dissepiments which make up most of the dissepimentarium show little size regularity; they range from small to large, the larger predominate. Significant features are nearly straight, continuous, horizontal, and somewhat thickened tabulae in parts of this zone.

Comparison with related forms. - In the Roberts Mountains at locality M1054, a subcerioid variety with corallite walls partly rounded transversely is associated with normal kirki; this fact suggests a phaceloid tendency (Merriam, 1940, pl. 16, fig. 6). An Hexagonaria-like species occurring in the Toiyabe Range at locality M1151 near Reeds Canyon (plate 25, fig. 10) has wide corallites and may be allied either to kirki of coral zone D or to Hexagonaria flexum (Stumm) of coral zone $F$.

Hexagonaria (Pinyonastraea) kirki has no described close relatives elsewhere. It is possible this form is derived from the stock which produced the corals assigned to Billingsastraea nevadensis.

Measurements.-Holotype USNM 94456; diameter of a mature corallite, $17 \mathrm{~mm}$; major septa, 20. Figured specimen USNM 159345: diameter of a mature corallite, $17 \mathrm{~mm}$; major septa, 23.

Occurrence.-Lower part of the Nevada Formation, unit 2. Devonian coral zone $\mathrm{D}_{2}$. Lone Mountain: locality M1052. Northern Roberts Mountains: locality M1054. Northern Antelope Range: locality M1053. At Lone Mountain this coral may range into coral zone $\mathrm{D}_{3}$ at locality M1052.

\section{Genus BILLINGSASTRAEA Grabau, 1917}

1917. Phillipsastraea (Billingsastraea) Grabau, p. 957. 1937. Billingsastraea Grabau. Stumm, p. 437, pl. 53, fig. 13, pl. 55, figs. 8a-b.

1949. Billingsastraea Grabau. Stumm, p. 35, pl. 16, figs. 8-11, ?fig. 7.

1951. Billingsastraea Grabau. Ehlers and Stumm (in part).

1953. Billingsastraea Grabau. Ehlers and Stumm, p. 1. 1956. Billingsastraea Grabau. Hill, p. F280, fig. 191-7.

Not 1958. Billingsastraea Grabau. Schouppé, p. 235-237.

1964. (?) Billingsastraea Grabau. Stumm, p. 43, pl. 40, figs. 1-3.

1964. Billingsastraea Grabau. Oliver, p. B1-B5, pls. 1-2.

1964. Radiastraea Stumm. Pedder, p. 446-449, pls. 71-73.

Type species. - Phillipsastraea verneuili Edwards and Haime, 1851 (by monotypy). According to Edwards and Haime, the type occurrence is in the State of Wisconsin; the type is now believed to have come from glacial drift.

Diagnosis.-Oliver's (1964) diagnosis is as follows: Astraeoid, thamnastraeoid, or slightly aphroid corals with calices having a central pit and a broad horizontal or reflexed peripheral platform. Septa are radially arranged and lightly to heavily carinate with zigzag or crossbar carinae. Major and minor septa extend from the periphery; minor septa terminate at the outer margin of the tabularium; major septa commonly extend to or almost to the axis. At their peripheral ends the septa abut against those in the adjacent corallite or are continuous into the next corallite. The tabularium is narrow and composed of closely spaced, horizontal complete tabulae. The dissepimentarium is composed of gently to strongly curved dissepiments that are horizontally arranged except next to the tabularia where they are inclined toward the corallite axes.

Remarks.-Grabau (1917, p. 957) introduced the 
name Billingsastraea in a subgeneric sense without definitive treatment. Stumm first defined Billingsastraea as a genus in 1937. Redefining the genus in 1949, Stumm (p. 35) in effect interpreted his genus Radiastraea (Stumm, 1937, p. 439) as an objective synonym of Billingsastraea, thus suppressing Radiastraea. As noted by Oliver, the species Radiastraea arachne Stumm (type species of Radiastraea) was regarded by Stumm $(1949$, p. 35) as a weakly carinate species of Billingsastraea. Oliver's diagnosis above supplements that of Stumm in taking into account the characters of $R$. arachne.

Because the internal features of "Phillipsastraea" verneuili Edwards and Haime, type species of Billingsastraea, are unknown, the status of this genus remains clouded. Pedder (1964, p. 447) regards certain species assigned to Billingsastraea by Ehlers and Stumm (1951; 1953) as constituting a separate but undescribed compound Heliophyllum-like genus; these are doubtless the strongly yardarm-carinate forms. He has accordingly resurrected Radiastraea for the noncarinate to not so strongly carinate species of the arachne type.

At present too little is known of the taxonomic significance of prominent crossbar or yardarm carinae to decide whether or not these features constitute a sufficient basis for separating the species bearing them as a genus distinct from the species presently in Billingsastraea which have noncarinate septa or zigzag carinae. The problem is similar to that in connection with Hexagonaria.

In accord with Stumm's 1949 review and the reevaluation of Oliver (1964), the term Billingsastraea is provisionally retained for the Nevada forms here dealt with, in the hope that eventually the type of verneuili may be sectioned and studied.

Billingsastraea nevadensis (Stumm) and B. arachne (Stumm) were both described from the lower part of the Nevada Formation at Lone Mountain, Eureka County, Nev. Both occur in the lower part of the Nevada (in unit 2) and in coral zone $D_{2}$; it is not improbable they are within the range of variation of a single species. However, full confirmation of this identity will depend upon variation studies of more complete suites of specimens from the same locality and horizon than are at present available. Probably the best course at this time is to consider $B$. arachne merely a subspecies of $B$. nevadensis.

Billingsastraea nevadensis (Stumm)

Plate 24, figures 1-3, 5, 6-8

1937. Billingsastraea billingsi nevadensis Stumm, p. 438, pl. 53, fig. 12, pl. 55, figs. 9a-b.

1940. Billingsastraea nevadensis Stumm. Merriam, pl. 12, fig. 1.
1949. Billingsastraea nevadensis Stumm, pl. 16, fig. 8.

Type and figured material. - Holotype USNM 94467; lower part of Nevada Formation, Lone Mountain. Figured specimens: USNM 159346, 159347, localities M1055, M1035, Antelope Range; USNM 159348-159350, locality M55, Lone Mountain. Devonian coral zone $\mathrm{D}_{2}$.

Diagnosis. - This thamnastraeoid Billingsastraea has uniformly thin finely wavy or zigzag septa and numerous weak zigzag elbow carinae. Longer major septa reach the axis; their waviness generally increases as they approach the center. Minor septa are twothirds the length of the major septa; their axial tips just enter the tabularium. Concentric dissepiment traces, close-set at the inner margin of dissepimentarium, form a false inner ring that normally has no significant thickening. Tabulae are mostly irregular, arched distally, and some of them are complete. Flat outer dissepiments range in size from small to large; inner steeply inclined dissepiments are small.

External features.-Ovoidal colonies that are $15 \mathrm{~cm}$ or more in greatest diameter show polygonal outlines resembling those of large corallites that have raised margins with the external appearance of a wall. Calice pits commonly lack the raised crateriform margin characteristic of subspecies arachne.

Transverse sections.-Major septa average about 16 , most of them extend to the axis; in the tabularium, major septa, wavy and irregular, commonly produce an incipient plexus, join laterally or with their opposite septa. Some individuals reveal a moderate thickening of both major and minor septa only in those parts where they pass from dissepimentarium to tabularium; others show no such thickening. No wall separates corallites, most septa pass into septa of adjacent corallites peripherally. Dissepiment traces are usually evenly concentric in the close-spaced periaxial area; they become more irregular or nearly straight in the more open peripheral area. Septal waviness varies considerably from those with numerous small, even bends without carinae to those with closely spaced, zigzag bends having fine sharply projecting carinae at the elbow angles. No crossbar (yardarm) carinae are present. Astraeoid patterns are slightly developed peripherally, but no aphroid tendencies have been recognized in this predominantly thamnastraeoid species.

Longitudinal sections.-The diameter of the tabularium is about one-third of or slightly less than the corallite diameter. In a broad zone of nearly flat lying dissepiments, small to large dissepiments have irregular distribution; limbs of larger dissepiments subtend as many as five small underlying ones. The innermost column of small dissepiments stands near vertical. The 
tabulae, rather closely spaced, commonly are arched distally in an irregular fashion and have a periaxial depression. A few tabulae nearly complete, most terminate as large tabellae. Carinal traces show in scattered patches. Horseshoe dissepiments are lacking.

Comparison with related forms. - Billingsastraea nevadensis differs from $B$. verrilli (Meek) in the structure of its septa, which are thickened within the dissepimentarium of verrilli (Smith, 1945, pl. 19, figs. $2 \mathrm{~b}-\mathrm{c}$; and in cellulose peels of a Meek paratype); $B$. nevadensis has uniformly thin septa in this region. $B$. verrilli, figured by Pedder (1964, pl. 71, figs. 1-5; pl. 72, figs. 4-5), is less thickened here than is Meek's paratype specimen, but it has thicker than normal nevadensis septa in the dissepimentarium.

Among the adequately illustrated species of Billingsastraea, the one under consideration bears a significant resemblance to $B$. affinis (Billings) as figured by Oliver (1964). The differences are a greater number of major septa (about 19 in affinis, 16 in nevadensis) and possibly in the vertical sides of calicular pits in affinis. Billingsastraea affinis, reported by Oliver $(1964$, p. B3) from the Grande Grève Formation of Coblenzian age, is possibly not a great deal older than $B$. nevadensis from the beds of coral zone $\mathrm{D}_{2}$.

Measurements.-The measurements of representative corallites of figured specimens are:

\begin{tabular}{|c|c|c|}
\hline USNM No. ... & 159847 & 159349 \\
\hline Diameter (in mm) & 14 & 11 \\
\hline
\end{tabular}

Occurrence.-Nevada Formation, unit 2; Devonian coral zone $\mathrm{D}_{2}$. Lone Mountain: localities 104 (Merriam, 1940), M55. Northern Roberts Mountains: locality 3 (Merriam, 1940). Northern Antelope Range: localities M1035, M1055. At localities 3 and 104 (Merriam, 1940) B. nevadensis is associated with subspecies arachne.

\section{Billingsastraea nevadensis subsp. arachne (Stumm) Plate 24, figure 4}

1937. Radiastraea arachne Stumm, p. 439, pl. 53, fig. 13; pl. 55, figs. 8a-b.

1940. Radiastraea arachne Stumm. Merriam, pl. 13, fig. 5 .

1949. Billingsastraea arachne (Stumm), p. 35, pl. 16, fig. 9, 10, 11.

1964. Radiastraea arachne Stumm. Oliver, p. B3.

1964. Radiastraea arachne Stumm. Pedder, p. 446-447, pl. 72, figs. $1-3$, pl. 73, figs. $1-5$.

Type material. - Holotype USNM 94458. Lower part of the Nevada Formation, Lone Mountain.

Diagnosis.-This Billingsastraea has uniformly thin, moderately wavy to only slightly wavy or nearly straight septa, with a few zigzag carinae limited to a few septa. The distal surface of type has prominent raised crateriform rim at the edge of calicular pits.
Remarks.-Stumm (1937, p. 439) defined Radiastraea to contain species having these features, together with an inner aulos or "tubular ring." Later Stumm (1949, p. 35) noticed that an aulos was not present; accordingly he concluded that $R$. arachne is a weakly carinate species of Billingsastraea. This appears to be a reasonable interpretation. Pedder (1964, p. 446-449) has reinterpreted Stumm's Radiastraea as a genus and has proposed its adoption to include arachne and verrilli (Meek).

Occurrence.-Lower part of the Nevada Formation, unit 2. Devonian coral zone $\mathrm{D}_{2}$. Lone Mountain: localities 58, 104, 105 (Merriam, 1940). Northern Roberts Mountains: localities 3, 36 (Merriam, 1940), M1073. Southern Roberts Mountains: locality 15 (Merriam, 1940). At localities 3 and 104 this subspecies occurs with typical Billingsastraea nevadensis.

\section{Billingsastraea? sp. T \\ Plate 25, figures 6-9}

This Billingsastraea? has thamnastraeoid to aphroid growth habit. Its thickened septa lack carinae but are minutely wavy. Septal dilation is rather evenly distributed radially through the dissepimentarium; there is a greater swelling of twisted axial segments in the tabularium. Closely spaced tabulae, mostly incomplete and irregular, have a slight proximal sag. In longitudinal section this species resembles Billingsastraea nevadensis (Stumm).

Billingsastraea? sp. $\mathrm{T}$ differs from $B$. nevadensis in lacking septal waviness and angulation carinae and in having thickened septa. Moreover, nevadensis normally is not aphroid.

The partly aphroid growth of this form is suggestive of Billingsastraea-like corals with dilated septa occurring in Nevada Formation, unit 4 (coral zone F) at Lone Mountain. These undescribed coral zone $\mathrm{F}$ forms are more appropriately classified as Aphroidophyllum Lenz (1961, p. 505) or Taimyrophyllum Chernychev 1941, the relationships of which have recently been discussed by Pedder (1964).

Occurrence.-Toiyabe Range, Nev.; Austin quadrangle, locality M1151, west range front 0.8 mile southsouthwest of mouth of Reeds Canyon. Lower part of Devonian limestones correlative with the Nevada Formation. Middle Devonian within the interval of coral zones $\mathrm{D}$ to $\mathrm{F}$.

\section{Family CYSTIPHYLLOIDAE Stumm, 1949}

Reference form.-Cystiphylloides aggregatum (Billings) 1859. Devonian; Ontario, Canada.

These compound and solitary Devonian cystimorphs lack septa beyond initial growth stages, except for traces or weak radiating septal ridges on mature calice 
floor and wall. The transverse thin sections of some species do not show septal crests. The calice is deep and has a V-shaped profile. The tabularium is generally narrow, in keeping with the deep, conical calice. The dissepimentarium is not abruptly set off from the tabularium. Straight tabulae are uncommon; the horizontal structures consist of two or more tabellae with bases nearly horizontal or axially inclined at a low angle. All the dissepiments are concave peripherally in lonsdaleioid fashion.

The Devonian Cystiphylloidae differ from the Silurian Cystiphyllidae in lacking the trabecular septal spines that extend inward from dissepiment surfaces. Transitional forms probably exist between the Cystiphylloidae and the Digonophyllidae, which generally have septal crests and ridges.

\section{Genus CYSTIPHYLLOIDES Chapman, 1893}

1859. Cystiphyllum aggregatum Billings, p. 137, text fig. 28.

1893. Cystiphylloides Chapman, p. 46.

1937. not Cystiphylloides Yoh p. 50-54, pl. V, figs. 1-4.

1940. not Cystiphylloides Yoh. Lang, Smith, and Thomas, p. 48.

1940. Cystiphylloides Chapman (in part). Stumm, p. 39 (in part); not pl. 19, figs. 1-7; not pl. 20, figs. 14-15.

1956. Mesophyllum (Cystiphylloides) Chapman, 1893. Hill, p. F319 (in part), fig. 219-6 (type).

Type species. - Cystiphyllum aggregatum Billings, 1859. Devonian; Onandaga, near Simcoe, Ontario, Canada. Cystiphylloides Yoh, 1937 is a homonym and is probably not congeneric with Cystiphylloides Chapman, although it has generally been so regarded (Stumm 1949, p. 39). Unfortunately the internal structure of Billings' type of Cystiphyllum aggregatum is unknown, and the specimen is lost. According to D. J. McLaren (written commun., Sept. 1, 1966), Billings' species is almost certainly the common Onondaga dendroid to phaceloid form, as suggested by Billings' figure of the exterior. Sections of this species are available; the diagnosis is based on them.

Diagnosis.-These are medium and large dendroid to phaceloid and solitary cystiphylloid Rugosa; individual corallites range from trochoid to cylindrical. The mature dissepimentarium, of medium width, is composed mostly of small- and medium-sized, rather uniformly globose dissepiments. The border between the tabularium and the dissepimentarium is rather well defined but not sharp; there is a change from small steep dissepiments to large axially inclined tabellae. The tabularium is medium wide to wide. Septa and septal spines or crests are commonly absent.

Remarks.-A series of transverse sections of a dendroid, a moderately compact colony from the Onondaga Limestone of Hagersville, Ontario (Royal Ontario Museum Collections No. $8950 \mathrm{H}$ ), (photographs of which were supplied by McLaren), show corallites in neanic and mature growth stages. None have septal crests, even at the periphery where they appear in some cystiphylloids. Most of the dissepiments decrease in size axially; they become less globose in the columns bordering the wide tabularium where there is a rather abrupt change to large tabellae.

Yoh's Cystiphylloides (1937), from the Middle Devonian of Kwangsi Province, South China, was proposed without reference to prior use of this generic name by Chapman. Yoh's excellent figures suggest that it is a solitary coral with a wider dissepimentarium and a narrower tabularium which is less abruptly set off from the former. Septal crests are present peripherally, a feature not noted in the Onondaga form.

Cystiphylloides, according to either Chapman's or Yoh's definition, rather conclusively does not belong in synonymy with Plasmophyllum where it has recently been placed by Birenheide (1964, p. 17).

The cystiphylloid corals from the Nevada Formation may be segregated as colonial or solitary and, on the basis of septal crests, into two groups; one group lacks septal crests entirely or has some scattered but poorly developed, and the other group has well-developed peripheral septal crests. Within this morphological range there is a great diversity of type with respect to features of the dissepimentarium and tabularium. The term Cystiphylloides of Chapman is applicable to some of these types, especially to the colonial forms. Other types, morphologically closer to Yoh's Cystiphylloides may require a new generic name. Generic names such as Mesophyllum and Digonophyllum are available for these cystiphylloides with false septa or septal crests alined radially in the separate growth cones.

Cystiphylloides robertsense (Stumm)

Plate 23, figures 1-4

1937. Mesophyllum robertsense Stumm, p. 440, pl. 53, fig. 14; pl. 55, figs. 10a-c.

Type material. - Holotype USNM 94459, Frazier Creek, northern Roberts Mountains; paratype USNM 94460, Lone Mountain, Eureka County, Nev. Lower part of the Nevada Formation.

Diagnosis. - The mature corallites are cylindrical and narrow for the genus; probably colonial. A definite peripheral zone of small dissepiments passes rather abruptly into an inner band of large dissepiments that are not sharply set off from the tabularium.

External features.-The cylindrical corallites have rather coarse external longitudinal ribs. The parallel alinement of corallites in the matrix. A bushy colonial grow th form, although no lateral connection was observed. 
Transverse section. - The peripheral zone shows about four columns of small dissepiments; at the axis there is a fairly abrupt change to large dissepiments. Within the outer band of small dissepiments there is stereoplasmic thickening but septal crests, if present, are indistinct. No septal crests were observed internally

Longitudinal section.-The change from small dissepiments to large ones in the peripheral zone is conspicuous, but the separation between the tabularium and the large dissepiments is indistinct; the innermost roughly horizontal arched features considered to be tabellae occupy the axial part of the corallite that is usually narrow.

Reproductive offsets.-Stumm (1937, p. 440) notes the presence of a calice offset in the holotype.

Comparison with related forms.-Other Great Basin cystyphylloids become cylindrical when mature, but this specimen is the only one I have reason to think may be a phaceloid colonial.

Measurements.-Figured specimen USNM 159343: mature corallite diameter $22 \mathrm{~mm}$; width of peripheral band of small dissepiments $3 \mathrm{~mm}$.

Occurrence. - Lower part of Nevada Formation, lower part of unit 2. Devonian coral zone $D$. Lone Mountain: locality M1046. Northern Roberts Mountains, Nev.; type locality of species on Frazier Creek. At Lone Mountain locality M1046 this coral is associated with Disphyllum nevadense (Stumm) and $D$. eurekaensis n. sp.

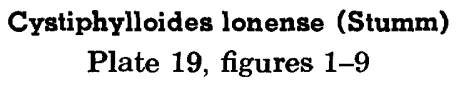

1937. Mesophyllum lonense Stumm, p. 440, pl. 53, fig. 15; pl. 55, figs. 11a-b.

Type material and figured specimens. - Holotype USNM 94461, paratype USNM 94461a. Figured specimens USNM 159322-159327: lower part of the Nevada Formation, Lone Mountain, Eureka County, Nev.

Diagnosis.-This medium-sized, solitary, ceratoid Cystiphylloides has large tabellae not sharply set off from large interior dissepiments; few recognizable septal crests are present in transverse sections, but the deep calice has weak, raised, discontinuous radial striations. Both large and small dissepiments are in the peripheral band.

Transverse sections.-About two-thirds the diameter of the mature stages consists of larger dissepiments and tabellae; a few large dissepiments are at the periphery. There are a few scattered septal crests in the peripheral band, and incomplete cones of stereoplasmic thickening occur at about the inner edge of the dissepimentarium.
Longitudinal sections.-Most dissepiments, including those in the peripheral band, are steeply inclined. The tabularium is commonly occupied by two large tabellae, which are either nearly flat or axially inclined at a low angle; in the early neanic stages there may be a few complete and flat tabulae.

Comparison with related forms.-The younger $C y s$ tiphylloides robertsense of coral zone $\mathrm{D}_{2}$ has a greater concentration of small dissepiments in the outer band of the dissepimentarium and is cylindrical and probably colonial when mature. Cystiphylloides americanum (Edwards and Haime) has a much wider dissepimentarium with numerous columns, the outer columns are nearly flat. Its tabularium usually shows several laterally contiguous tabellae in a rather wide and fairly discrete tabularium.

Measurements.-Three figured specimens (in $\mathrm{mm}$ ) :

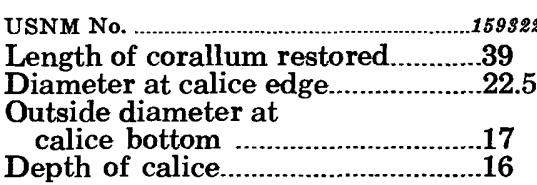

$\begin{array}{cc}15932 s & 159324 \\ 69 & 70 \\ 31 & 31 \\ 17 & 23 \\ 35 & 29\end{array}$

Occurrence.-Lower part of the Nevada Formation, unit 1. Devonian coral zone C. In association with $P a$ piliophyllum elegantulum, Siphonophrentis (Breviphrentis) kobehensis, and Acrospirifer kobehana. Lone Mountain: localities M74, M286.

\section{Cystiphylloides sp. $d$ \\ Plate 19, figures 10, 11}

1884. (?) Cystiphyllum americanum Milne-Edwards. Walcott, p. 106.

1937. (?) Mesophyllum flexum Stumm, p. 441, pl. 55, figs. 12a-b.

1938. (?) Mesophyllum vesiculosum (Goldfuss). Stumm, p. 483 , pl. 59, figs. 8a-b.

These cystiphylloid rugose corals resemble Cystiphylloides americanum (Edwards and Haime). They occur in the lower part of the Nevada Formation, probably ranging up through coral zone $\mathrm{D}$ to coral zone $\mathrm{E}$. In coral zone $D$ these corals are represented by the form here referred to as Cystiphylloides $\mathrm{sp}$. $\mathrm{d}$. There is insufficient material to justify a specific name at present.

Like C. americanum, this form grows to a large size with numerous columns of medium and large dissepiments that are not sharply set off from from tabellae in the axial vicinity. In $C$. sp. $d$ the dissepiments are inclined steeply and many are elongate, whereas in $C$. americanum the peripheral dissepiments are less steeply inclined. The calice of $C$. americanum is deep and bellshaped, whereas the calice of $C$. sp. $d$ may be very deep and conical or funnel shaped. No septal crests are noted. 
Occurrence.-Nevada Formation, unit 2. Devonian coral zone $\mathrm{D}_{2}$. Southern Sulphur Spring Range: locality M36.

\section{Family DIGONOPHYLIIDAE Wedekind, 1924}

Reference form.-Mesophyllum defectum Schlüter 1889. Middle Devonian, Germany.

Large, solitary, pervasively dissepimented rugose corals have septa which tend to be discontinuous lamellar plates, both vertically and radially. Bilateral symmetry is obscure in mature growth stages; at the mature stage the fossula is usually not clearly defined.

The Digonophyllidae include forms ranging from a type with conspicuous septa to a type with greatly reduced mature septa, which may appropriately be called cystimorphs. The dissepimentarium is always wide; the tabularium is narrow and may be poorly differentiated. Many of these corals have a wide calice brim or platform.

As noted by Wedekind (1924), the septal tissue of the Digonophyllidae develops discontinuously in successive growth cones (septal cones of Wedekind).

The family and generic classification of these corals remains in a confused state. Multiplication of genera by Wedekind and associates reflects the taxonomic philosophy of the extreme "splitter," although the coral divisions appear to have been related to stratigraphic units. Birenheide (1964), in a painstaking and detailed revision, eliminates many of the Wedekind genera. Hill (1956, p. F314-F320) has adopted some Wedekind genera as subgenera in a practical and reasonably satisfactory scheme based on current understanding of this complex group.

For purposes of this study two subfamilies of the Digonophyllidae are adopted: Digonophyllinae and Zonophyllinae. In the Great Basin Province the Digonophyllidae appear in Devonian coral zone $\mathrm{D}_{2}$ and are not known above coral zone F. Here, as in Germany, they are characteristic of Middle Devonian, especially the Eifelian.

\section{Subfamily DIGONOPHYLLINAE Wedekind, 1924}

Reference form.-Mesophyllum defectum Schlüter 1889. Middle Devonian, Germany.

The large Digonophyllidae have septa uniformly developed or sporadic and vestigal in growth cones. The septa in the growth cones are either radially continuous plates or radially alined ridges and crests. Strip carinae are present in the marginarium of some genera. Normal but irregular dissepiments of the periaxial band change peripherally to irregularly lonsdaleioid. The dissepiment pattern is highly complex and nonuniform in the marginarium of species having peripherally suppressed septa.
In all Digonophyllinae the tabularium is relatively narrow and poorly differentiated and lacks straight tabulae. The calice is deep and conical, floored by two or more tabellae; in those forms having a wide brimplatform, the inner conical part of the calice is a steep-sided pit.

Hill (1956, p. F317) and Birenheide (1964, p. 6) note the presence of a fossula in some Digonophyllidae; however, no fossula is recognized in the Great Basin species, and it seems probable that symmetry features of this kind are not generally conspicuous in the Digonophyllinae.

No preparations of Great Basin material convincingly show vertical continuity of homologous septal lamellae from one incremental growth cone to those above and below, within successive nested cone sequences.

The radially broken septa of some species commonly have such closely spaced component crests that the septa almost look continuous. Observed in transverse thin section, each crest or spine is an outgrowth from one or more tabellae or from one or more of the dissepiments.

As noted elsewhere, it is probable that Digonophyllinae with almost wholly lonsdaleioid dissepiments intergrade with the Cystiphylloidae.

Genera and subgenera classified with the Digonophyllinae are as follows:

Digonophyllum (Digonophyllum) Wedekind, 1923

Digonophyllum (Mochlophyllum) Wedekind, 1923

Mesophyllum (Mesophyllum) Schlüter, 1889

Mesophyllum (Arcophyllum) Markov, 1926

Arcophyllum is classified as a subgenus under Mesophyllum by Hill (1956, p. F318). Other possible subgenera of Mesophyllum are: Lekanophyllum Wedekind, 1923, Atelophyllum Wedekind, 1925, and Dialytophyllum Amanshauser, 1925.

The Digonophyllinae appear in Early and early Middle Devonian coral subzones $\mathrm{D}_{2}$ and $\mathrm{D}_{3}$ of the Great Basin with the genera Mesophyllum and Arcophyllum. Corals of this subfamily peak in the higher Eifelian interval of coral zone $\mathbf{F}$.

\section{Genus MESOPHYLLUM Schluter, 1889}

1956. Mesophyllum Schlüter 1889. Hill, p. F318.

Type species. - Mesophyllum defectum Schlüter, 1889. Middle Devonian; Eifel district, Germany.

Diagnosis. - These Digonophyllinae have nonuniformly discontinuous septa which become obsolete peripherally in a wide band of irregularly lonsdaleioid dissepiments, with or without localized groups of strip carinae.

Remarks. - The corals assigned to Mesophyllum range in structure from maturely cylindrical cysti- 
morphs with only a few weak septal traces and scattered or no bar carinae to those with numerous discontinuous and fairly strong continuous irregularly thickened septa and abundant strip carinae.

At present the adoption of Mesophyllum as a genus with subgenera, more or less in accord with the scheme used by Hill (1956, p. F317-F320) seems to be a reasonably satisfactory rationalization of the taxonomic dilemma in this difficult and complex group. Birenheide's detailed systematics (1964) are, on the other hand, quite different; he classifies Mesophyllum as a subgenus of Plasmophyllum.

Of the seven subgenera of Mesophyllum listed by Hill, only two, Mesophyllum (Mesophyllum) and Mesophyllum (Arcophyllum), are pertinent in this study. Cystiphylloides Chapman is not here classified as a subgenus of Mesophyllum.

Subgenus MESOPHYLLUM sensu stricto

1956. Mesophyllum (Mesophyllum). Hill, p. F318, fig. 219-5.

Type species.-Same as genus.

Diagnosis.-This Mesophyllum has a highly discontinuous, patchy, nonuniform, and unstable pattern of prevailingly weak septa, with or without a few rather poorly defined bar carinae.

Remarks.- On the one hand, this subgenus includes cystimorphs resembling Cystiphylloides with only a few weak septal traces; on the other, it probably grades into the sugenus Arcophyllum with partly strong septal crests and numerous bar or strip carinae.

Corals of this general category occur in Nevada Formation, unit 2. Because they are known only from fragmentary material, they are accordingly designated provisionally by letter only.

\section{Mesophyllum (Mesophyllum) sp. b}

Plate 21, figures 1, 2

Figured specimens.-USNM 159334. Lower part of the Nevada Formation, Sulphur Spring Range, Nev.

Early ephebic transverse sections show many rather stout septal crests of variable length; most of these are concentrated in a zone halfway between wall and axis. Inner dissepiments and tabellae are large. Carinae were not recognized. In fully mature stages the septal crests probably become thinner and more scattered.

Occurrence.-Lower part of the Nevada Formation, unit 2; Devonian coral zone $\mathrm{D}_{2}$. Southern Sulphur Spring Range, Nevada; locality M36.

Mesophyllum (Mesophyllum) sp. c

Plate 21, figures 3,4

Figured specimens.-USNM 159335. Lower part of the Nevada Formation, northern Antelope Range, Nev.
Mature transverse sections show sporadic, mostly vague septal traces in groups with widely scattered short septal crests. Inner dissepiments and tabellae are relatively smaller than in sp. b. In longitudinal section all the rather small dissepiments in a very wide zone are steeply inclined, the tabularium is very narrow, and the septal cones and calice are acutely conical. Thickened trabecular septal crests are developed at the inner edge of the dissepimentarium. Carinae were not recognized.

Occurrence. - Lower part of Nevada Formation, unit 2; Devonian coral zone D. North end of the Antelope Range, Eureka County, Nev.; locality M1035.

Subgenus ARCOPHYLLUM Markov, 1926 (as a genus)

1926. Arcophyllum Markov, p. 49-60, pl. 3.

1940. Arcophyllum Markov. Lang, Smith, and Thomas, p. 20, 41.

1949. Arcophyllum Markov. Stumm, p. 39, 43, pl. 21, figs. 1-3.

1922. Cosmophyllum Vollbrecht (not Blanchard, 1851), p. 17.

1925. Cosmophyllum Vollbrecht. Wedekind, p. 39.

1931. Cosmophyllum Vollbrecht. Wedekind and Vollbrecht, pl. 28, figs. 1-6, pl. 32, fig. 8 .

1931. (?) Pseudocosmophyllum Wedekind and Vollbrecht, pl. 19, figs. 1-4, pl. 20, figs. 1, 2, 5 .

1931. (?) Hemicosmophyllum Wedekind and Vollbrecht, pl. 31, figs. 1-12, pl. 32, figs. 1-7.

1932. Cosmophyllum Vollbrecht. Wedekind and Vollbrecht, pl. 33, figs. 1-4.

1932. Hemicosmophyllum Wedekind and Vollbrecht, pl. 36, figs. $1-8$

1932. (?) Pseudocosmophyllum Wedekind and Vollbrecht, pl. 38, figs. 1-5.

1937. Mesophylloides kirki Stumm, p. 441, 442, pl. 55, figs. 13a-b.

1956. Mesophyllum (Arcophyllum) Markov. Hill, p. F318, fig. 219-1.

1956. (?) Mesophyllum (Hemicosmophyllum) Wedekind and Vollbrecht. Hill, p. F318, fig. 219-3a, b, c.

Type species.-Arcophyllum typus Markov, 1926 (by original designation). Middle Devonian; Calceola beds, western slope of Ural Mountains, Russia.

Diagnosis. - The solitary Digonophyllinae have large, commonly elongate subcylindrical mature growth stages with thick external annulations and rejuvenescence constrictions. The calice, deep and inversely bell shaped to funnel shaped, is reflected peripherally as a platform or brim, which is either inclined axially, flattened, or broadly convex distally. The brim surface is ornamented by numerous edges of strip carinae. Septa are numerous, somewhat withdrawn from axial tabellae, and range from continuous to discontinuous as radially alined septal crests, the more continuous septa predominate. Septa are thickened locally in the tabularium; septa pass peripherally into a wide band of irregular dissepiments, within which some septa terminate short of the outer wall. Concentric rows of strip carinae are vaguely defined 
peripherally in transverse thin sections; outermost strip carinae are commonly detached from the septa with which they are alined. Minor septa range from about one-half to nearly full length of the major septa; minor septa are more prone to discontinuity as alined septal crests. The dissepimentarium is wide, is commonly three-fourths of corallum radius, and consists of mostly small steeply inclined dissepiments which pass axially without discontinuity into the narrow medial zone of the tabellae. Outer dissepiments are mostly lonsdaleioid; inner dissepiments form concentric irregular chevrons and forks. Flat continuous tabulae are few. In longitudinal thin section, prominent isolated groups of diagonally inclined strip carinae abut in the outer dissepimentarium against parts lacking carinae.

Remarks.-Because of delay in publication, Vollbrecht's (1922) genus Cosmophyllum appeared in print before Markov's (1926, p. 49) Arcophyllum, with which it is probably congeneric (Lang and others, 1940 , p. 20). However, the generic name Cosmophyllum, being an homonym, is superseded by Arcophyllum (Stumm, 1949, p. 43; Hill, 1956, p. F318).

Cosmophyllum-like digonophyllid Rugosa similar to Arcophyllum are recorded by Wedekind (1924, p. 84, $85 ; 1925$, p. 70,$71 ; 1926$, table, p. 201) from the middle part of the Middle Devonian, Eifel district, Germany. The species in question are variously assigned to Cosmophyllum, Hemicosmophyllum, and Pseudocosmophyllum. Further taxonomic revision of these Eifel district genera is called for, in the light of field stratigraphic occurrence, to establish their relationship to Arcophyllum. Available illustrations of Hemicosmophyllum and Pseudocosmophyllum suggest that these corals may be closely related to, if not synonyms of, Arcophyllum; detailed variation study is needed, noting such features as presence of strip carinae in fully mature individuals. Hill's (1956, p. F317-F319) revision of the Digonophyllinae interprets Arcophyllum and other genera of this subfamily as subgenera of Mesophyllum Schlüter. Arcophyllum-like corals from southeastern Alaska have continuous septa, not the radially broken septa of Mesophyllum, and may accordingly be more closely allied to the genus Digonophyllum.

\section{Mesophyllum (Arcophyllum) kirki (Stumm) \\ Plate 21, figures 5-7; plate 22, figures 1-6}

1937. Mesophylloides kirki Stumm, p. 441, pl. 55, figs. 13a-b. Type and figured material.-Holotype USNM 94463; figured specimens USNM 159336-159342. Lower part of Nevada Formation, Lone Mountain, Eureka County, Nev.

Diagnosis.-This large Arcophyllum has a subcylin- drical mature corallum. The wide dissepimentarium consists of many columns of small steeply inclined dissepiments; the relatively narrow tabularium has few tabellae. The septa are withdrawn from the axis, somewhat thickened toward axis, and partly discontinuous as septal crests. Strip carinae of the peripheral part of the dissepimentarium are conspicuous in longitudinal sections, inconspicuous or shadowy in transverse sections. There is no stereozone, fossula, or other indication of bilateral symmetry in the mature corallum. The funnel-shaped calice has a wide brim, which is distally convex and proximally inclined toward narrow axial pit.

External features.-The epitheca is thin and is absent over most of mature surface, possibly due to wear. The complete coralla of some individuals are very elongate and have annular folds and rejuvenescence constrictions. Strip carinae project conspicuously from the wide calice brim.

Transverse sections.- The septal count is 80 ; this count includes minor septa, some of which are nearly as long as the major septa; some reach the corallum periphery, but most become unrecognizable peripherally in the generally complex dissepiment tissue. The septa are partly continuous and partly discontinuous as septal crests. Minute to small lonsdaleioid dissepiments compose a broad peripheral band; the dissepiments increase in size axially and pass without discontinuity into the tabellae of the narrow tabularium. Inner dissepiments are composed of a complex tissue which includes concentric but uneven traces, herringbone chevrons, forks, and minute semiglobose dissepiments that terminate against a single septum at all edges. Septal thickenings are of the tapering variety, without nodes and bumps of the acanthophylloids. In transverse sections the strip carinae appear as concentric radial rows of shadowy yet translucent thickenings mainly within the peripheral lonsdaleioid part of the dissepimentarium.

Longitudinal sections.-The narrow tabularium about one-sixth the diameter of mature growth stages, consists of three or four axially inclined tabellae or less commonly a single complete tabula. Small peripheral dissepiments reveal a progressive size increase axially and pass without break into the less steeply inclined tabellae. Groups of prominent strip carinae, which terminate abruptly against the normal dissepiments, reveal an earlier growth stage calice brim.

Comparison with related forms.-Mesophyllum (Arcophyllum) kirki of this report is, with some misgivings, assigned to Stumm's species founded upon an incomplete specimen from Nevada Formation, unit 2 at Lone Mountain; this unit is also the source of the 
material here described. The holotype transverse thin section of Stumm's Mesophylloides kirki shows the inner part of a corallum lacking the outer dissepimentarium band which normally reveals strip carinae in Arcophyllum. Stumm's holotype has thinner, more continuous septa with fewer septal crests than the specimens here described.

The material referred to Mesophyllum (Arcophyllum) kirki resembles $M$. (A.) dachsbergi (Vollbrecht) and $M .(A$.$) limbatum (Wedekind and Vollbrecht),$ the first was originally placed in Cosmophyllum and the second in Hemicosmophyllum. Mesophyllum (Arcophyllum) dachsbergi differs from $M$. (A.) kirki in having a broader tabularium and more numerous tabellae. These differences apply also to $M$. (A.) limbatum. An undescribed Middle Devonian Arcophyllumlike coral from the Alberto Islands, southeast Alaska, has continuous septa, a wider tabularium with more numerous tabellae, and a well-developed strip carinae in the larger individuals.

Occurrence.-Lower part of the Nevada Formation, unit 2. Devonian coral subzone $\mathrm{D}_{3}$. Lone Mountain; localities M29, M1036. The corals here assigned to Mesophyllum (Arcophyllum) kirki characterize the uppermost beds in the "Spirifer pinyonensis" zone of previous usage. Comparison with Arcophyllum dachsbergi and $A$. limbatum suggests that coral subzone $\mathbf{D}_{3}$ is within the Middle Devonian. According to Wedekind and Vollbrecht (1931, pl. 28; 1932, pl. 36), Arcophyllum dachsbergi and A. limbatum occupy the zone of "Cosmophyllum dachsbergi" at Gerolstein, Eifel district, Germany. Wedekind (1925, p. 71 table) assigns the zone of "Cosmophyllum dachsbergi" to the upper part of his coral zone "St-Stenophyllumstufe," which is shown by him as well up in the middle Middle Devonian. Markov's type of Arcophyllum, being reported from Calceola-bearing beds of the Ural Mountains, may be older. The comparable southeast Alaskan Arcophyllum-like coral from the Alberto Islands is associated with Acanthophyllum, Australophyllum, and Heliolites in a fauna which probably underlies that containing Stringocephalus in this Alaskan stratigraphic section.

\section{Subfamily ZONOPHYLIINAE Wedekind, 1924}

Reference form.-Zonophyllum duplicatum Wedekind. Early Middle Devonian; Germany.

The cystimorph Digonophyllidae lack continuous septal lamellae; septal crests in growth cones that tend to be greatly thickened stereoplasmically, form septal wreaths or festoons where in contact laterally.

The Zonophyllinae range from cystimorphs with a few sporadic septal crests to those with radially alined, usually stout thickened crests and either a crescentic festoon or a completely circular stereoplasmic septal wreath.

Nepionic growth stages have thick stumpy septa in lateral contact. The stereoplasm of septal wreaths passes from one growth cone to those adjacent, as revealed in longitudinal thin section.

In Germany and in the Great Basin, the Zonophyllinae are characteristic of the early Middle Devonian; none have been recognized above coral zone $D_{2}$.

\section{Genus ZONOPHYLLUM Wedekind, 1924}

1924. Zonophyllum Wedekind, p. 12-21, figs. 1-8.

1940. Zonophyllum Wedekind, Lang, Smith, and Thomas, p. 142.

1949. Zonophyllum Wedekind, Stumm, p. 46-47, pl. 22, figs. 16-22.

1956. Zonophyllum Wedekind, Hill, p. F314-F315 (in part), fig. 216-1a-c.

Type species.-Z. duplicatum Wedekind by subsequent designation, Lang, Smith and Thomas (1940 p. 142). Lower Middle Devonian; Nohner Schichten at Nohn Eifel district Germany. From Wedekind's (1924, p. 85) zone D (Digonophyllumstufe), which is the lowermost Middle Devonian as interpreted by him.

Diagnosis.-Medium-size and small solitary cystiphylloids of ceratoid to cylindrical growth habit have thick stumpy to long septal crests in the peripheral zone of mature individuals; in longitudinal section the septal crests reveal thick trabecular spines which are directed distally and axially. The peripheral zone of small and medium-sized steeply inclined dissepiments passes axially into a zone of large dissepiments and periaxial tabellae. The axial zone has irregular, distally convex tabulae, some of which may be almost flat and wide. The ontogeny is distinctive. The late nepionic stage has about twelve thick stumpy septa touching laterally and has a suggestion of bilateral symmetry though no specific cardinal septum may be recognizable. In mid-neanic stage, there is a peripheral zone of dissepiments with thinner septal crests and an inner periaxial zone of thickened septal crests forming a septal wreath. In later growth stages, dissepiments and tabellae are introduced between the two septal zones. Septal crests are usually thick and numerous peripherally in earlier ephebic stages. Advanced ephebic stages are cystiphylloid with traces of septal crests.

Remarks.-Wedekind's (1924) researches by means of serial sections demonstrated that cystiphylloid rugosa of the Zonophyllum group were distinct from those of the true Cystiphyllum group. In this connection ontogenetic changes seem to be highly significant. Cystiphyllum itself is a Silurian genus (Lang and others, 1940, p. 48). The Devonian strata include descendants and no doubt numerous homeomorphic strains, such as Zonophyllum of the late Early and the Middle 
Devonian. In accordance with Wedekind's views (1924, p. 29), the early Middle Devonian Zonophyllum group was possibly the ancestral stock whence came the very numerous Digonophylloids of the ensuing Middle Devonian, all of which include cystiphylloid types.

Wedekind's theory of the septal cone (septalkegel) is set forth in connection with his description of Zonophyllum and its presumed evolutionary offshoots (1924, p. 21). This theory is reviewed by Hill (1956, p. F252, F314), who noted that in some of the rugose corals under consideration, septal tissue is developed only in successive inverse cones of thickening in which large trabeculae are present.

Zonophyllum haguei n. sp.

Plate 20, figures \&, 4, 9, 10

Type material.-Holotype USNM 159333, paratype USNM 159331; Grays Canyon, Eureka district, Nevada. Lower part of the Nevada Formation; coral zone $\mathrm{D}_{2}$.

Diagnosis.-Zonophyllum has a peripheral wreath of thick septal crests in the dissepimentarium and small very steep outer dissepiments. For part of the septal wreath, thick crests are joined discontinuously in a general stereoplasmic mass. The tabularium is occupied by large axially inclined tabellae and rather widely spaced tabulae which are, for the most part, distally convex.

External features.-The mature corallum is rather small and subcylindrical.

Transverse sections.-All dissepiments and tabellae are concave peripherally. There is progressive increase in size from small outer dissepiments to the large tabellae but no discrete border between dissepimentarium and tabularium. Some thick outer septal crests originating at or near the outer wall penetrate two or more rows of the small peripheral dissepiments. Stubby septal crests are sparsely developed within the tabularium.

Longitudinal sections. - The stereoplasmic deposits in the outer septal wreath partly fill the dissepimentarium. Large and elongate trabeculae extend inward and distally; in some instances they penetrate columns of smaller dissepiments. Dissepiments merge with size increase into large less steeply inclined periaxial tabulae. A few nearly flat tabulae may be more than onethird the corallite diameter in the mature stages.

Comparison with related forms.-Zonophyllum haguei differs from $Z$. duplicatum Wedekind, the type species, in lacking a well-defined inner wreath of thickened septal spines; the outer wreath of spines in haguei shows a more extensive deposit of stereoplasm. Other forms assigned to Zonophyllum from the Great Basin may represent distinct species but, being known from insufficient material, are not formally described.

Occurrence.-Nevada Formation, unit 2; Devonian coral subzone $\mathbf{D}_{2}$. Grays Canyon, Northern Fish Creek Range; localities M3, M51.

\section{Zonophyllum sp. a \\ Plate 20, figures 5, 6}

Figured specimens.-USNM 159332; lower part of the Devonian section, Ranger Mountains, Nevada.

Septal crests are short and scattered, not joined as in haguei, to form a discrete septal wreath. The tabellae are large in the wide tabularium.

Occurrence.-Lower part of Devonian section; probably coral zone $D_{1}$. Ranger Mountains, Nev.: locality M1058.

\section{Zonophyllum sp. b}

Plate 20, figures 11, 12

Figured specimens.-USNM 159351, lower part of the Nevada Formation; northern Fish Creek Range, Nevada.

The few septal crests are largely confined to an inner zone of diffuse stereoplasmic thickening which borders the dissepimentarium.

Occurrence.--Lower part of Nevada Formation, unit 2; Devonian coral zone $\mathrm{D}_{2}$. Grays Canyon, northern Fish Creek Range; locally M51.

\section{LOCALITY REGISTER}

(see figs. 1, 2, 3, 4)

I. Southern Great Basin

1. Desert Range, Clark County, Nev.

Locality M1057. - Army Map Service, Las Vegas, Nev., quadrangle; southwest edge of Desert Range east of Braun's Playa, in the W1/2 sec. 10, T. 16 S., R. 58 E., altitude 3,200 ft. Early Middle Devonian. Collected by C. R. Longwell.

2. Ranger Mountains, east of Frenchman Flat, Clark County, Nev.

Locality M1034. - Frenchman Lake SE quadrangle, Nevada; lat $36^{\circ} 46^{\prime} 45^{\prime \prime}$ N., long $115^{\circ} 52^{\prime} 00^{\prime \prime}$ W. Between 10 and $25 \mathrm{ft}$ above base of Nevada Formation. Collected by F. G. Poole.

Locality M1058.-Frenchman Lake quadrangle, Nevada; southeast side of Frenchman Flat, 1.5 miles east of Nye County-Clark County line in higher part of the southern Ranger Mountains; $1,500 \mathrm{ft}$ northwest of summit 4907. Limestone about $20 \mathrm{ft}$ above base of Nevada Formation; fossil zone 4 (Devonian unit A) of M. S. Johnson and D. E. Hibbard (1957)

3. Northern Panamint Mountains, Ubehebe district, Calif.

Locality M184.-Marble Canyon quadrangle, California; south side of Andy Hills in northwest corner of quadrangle, east side of Hidden Valley, on central ridge of Andy Hills near summit 5612. Upper part of McAllister's (1952, p. 15-17) Hidden Valley Dolomite, unit 3b containing Papiliophyllum and Costispirifer arenosus.

Locality M1065.-Marble Canyon quadrangle, California. Andy Hills, south side; measured section across Mc- 
Allister's unit $3 \mathrm{~b}$ of the Hidden Valley Dolomite; in same area as locality M184. Zoned collections A through H by J. F. McAllister, April 1965.

4. Funeral Mountains, Calif.

Locality M1059.-Ryan quadrangle, 1.8 miles N. $48^{\circ} \mathrm{W}$. of Pyramid Peak, Funeral Mountains. Uppermost part of Hidden Valley Dolomite with rugose coral fauna. Late Early Devonian. Collected by J. F. McAllister, June 1962.

Locality M1060.-Ryan quadrangle, 1.6 miles N. $58^{\circ} \mathrm{W}$. of Pyramid Peak, Funeral Mountains. Uppermost part of Hidden Valley Dolomite with rugose coral fauna. Late Early Devonian. Collected by J. F. McAllister, April 1962.

Locality M1061. - Ryan quadrangle, northwest slope of 4298 hill, 4.5 miles S. $47^{\circ}$ E. of Pyramid Peak, Funeral Mountains, altitude 3,750 ft. Uppermost part of Hidden Valley Dolomite with rugose coral fauna. Collected by J. F. McAllister, May 1964.

Locality M1062.-Ryan quadrangle, 6.2 miles $\mathrm{S} .71^{\circ} \mathrm{E}$. of Pyramid Peak, Funeral Mountains, altitude 3,450 ft. Uppermost part of Hidden Valley Dolomite with rugose coral fauna. Collected by J. F. McAllister, November 1963.

Locality $M 1063 .-$ Ryan quadrangle, 4.7 miles S. $51^{\circ} \mathrm{E}$. of Pyramid Peak, Funeral Mountains, altitude 3,700 ft. Uppermost part of Hidden Valley Dolomite with rugose coral faunas. Collected by J. F. McAllister, April 1965.

Locality M1064.-Ryan quadrangle, 6.23 miles S. $72^{\circ} \mathrm{E}$. of Pyramid Peak, Funeral Mountains, altitude 3,450 ft. Uppermost part of Hidden Valley Dolomite with rugose coral faunas. Collected by J. F. McAllister, March 1965.

\section{South-central Great Basin}

1. Hot Creek Range, Nev., middle part

Locality M1066. - Army Map Service, Tonopah, Nev., sheet. Probably in Hot Creek Canyon about 4 miles west-northwest of Hot Creek Ranch houses. Devonian including lower part of Nevada Formation with rugose corals. Collected by H. E. Cook (thesis, Univ. California, Berkeley, 1966).

2. Monitor Range, Nev., middle part

Locality M1067. - Army Map Service, Tonopah, Nev. sheet. Dobbin Summit, northern Nye County, Nev.; 1 mile southeast of East Dobbin Summit Spring on east side of canyon; west edge sec. 32, T. 13 N., R. $49 \mathrm{E}$. Lower part of Rabbit Hill Limestone.

Locality M1068.-Dobbin Summit, northern Nye County, Nev.; same as M1067, but a higher zone in Rabbit Hill Limestone.

Locality M1069.-Dobbin Summit, northern Nye County, Nev.; same as M1067, but upper part of Rabbit Hill Limestone.

\section{Central Great Basin}

1. Monitor Range, northern part

Locality M48. - Horse Heaven Mountain quadrangle, Nevada. West side Copenhagen Canyon, southeast slope Rabbit Hill, altitude 7,100 ft. Type section Rabbit Hill Limestone, Lower Devonian.

Locality M49. - Horse Heaven Mountain quadrangle, Nevada. One mile north of Locality M48, SE1/4 SE1/4 sec. 35, T. 16 N., R. 49 E.; in Rabbit Hill Limestone.

Locality M187. - Horse Heaven Mountain quadrangle,
Nevada. Same as Locality M48 on southeast side of Rabbit Hill. Rabbit Hill Limestone, Lower Devonian.

2. Antelope Range, northern part

Locality M1035. - Bellevue Peak quadrangle, Nevada. North tip of Antelope Range, west side of lower slope east of hill 6754 , altitude 6,680 ft. Nevada Formation, unit 2.

Locality M1035a. - Same as Locality M1035, but a lower stratigraphic horizon.

Locality M1053. - Bellevue Peak quadrangle, Nevada. North end of Antelope Range, NE $1 / 4$ sec. 16, T. $16 \mathrm{~N}$, R. 51 E., 2,200 ft north-northwest of summit 7602, altitude 7,000 ft. Nevada Formation, unit 2.

Locality M1055. - Bellevue Peak quadrangle, Nevada. North end of Antelope Range; top of spur, altitude 7,100 $\mathrm{ft}$ and $500 \mathrm{ft}$ southwest of M1053. Nevada Formation, unit 2.

3. Southern Fish Creek Range

Locality M1033. - Bellevue Peak quadrangle, Nevada. North tip of Fenstermaker Mountain, 3 miles southwest of Fish Creek Springs near top of range at altitude 6,700 $\mathrm{ft} ; 1,200 \mathrm{ft}$ north of southern edge of quadrangle. Nevada Formation, unit 2.

Locality M1070.-Cockalorum Wash quadrangle, Nevada. First north-south ridge east of southern Fish Creek Range, near south boundary of Eureka County; 0.8 mile southeast of Eightmile Well near top of knob at altitude 6,400 ft. Nevada Formation, unit 2.

Locality M1043.-Cockalorum Wash quadrangle, Nevada. One mile south of Nyeka (BM 7352), on line between secs. 4 and 5, T. 14 N., R. 52 E. Limestone conglomerate.

4. Northern Fish Creek Range

Locality M3.-Pinto Summit quadrangle, Nevada. Near mouth of Grays Canyon, 1 mile south of Pinnacle Peak and $800 \mathrm{ft}$ east of quadrangle boundary; east side of canyon near bottom, altitude 7,250 ft. Nevada Formation, unit 2.

Locality M51.-Same as Locality M3.

5. Mahogany Hills

Locality M27.-Bellevue Peak quadrangle, Nevada. Combs Peak area, 1.7 miles south of Combs Peak on top of spur in saddle at altitude 7,520 ft. Nevada Formation, unit 2.

Locality M1071.-Whistler Mountain quadrangle, Nevada. Mahogany Hills, east side (Mountain Boy Range) at Modoc Peak; near quadrangle boundary at south side of Modoc Peak. Nevada Formation, units 1 and 2.

Locality M1084. - Bellevue Peak quadrangle, Nevada. West side of Mahogany Hills, 1.75 miles west-southwest of summit of Combs Peak. Lower part of Nevada Formation.

6. Lone Mountain (see fig. 3)

Locality M1045.-Bartine Ranch quadrangle; Lone Mountain, northwest side, $2,200 \mathrm{ft} \mathrm{S}$. $50^{\circ} \mathrm{W}$. of U. S. Mineral Monument No. 6828 and about 1 mile northwest of summit of Lone Mountain, Nevada Formation, unit 2, upper $250 \mathrm{ft}$.

Locality M1052.-Bartine Ranch quadrangle; Lone Mountain, northwest side. Same as locality M1045.

Locality M1048.-Bartine Ranch quadrangle; Lone Mountain, northwest side, $2,500 \mathrm{ft} \mathrm{S} .33^{\circ} \mathrm{W}$. of U. S. Mineral Monument No. 6828, altitude 6,640 ft. Nevada Formation, unit 2.

Locality M286.-Bartine Ranch quadrangle; Lone Mountain, northwest side, $2,700 \mathrm{ft} \mathrm{S}$. $39^{\circ}$ W. of U.S. Mineral 
Monument No. 6828, altitude 6,560 ft. Nevada Formation, unit 1.

Locality M1036.-Bartine Ranch quadrangle; Lone Mountain, northwest side, $3,500 \mathrm{ft} \mathrm{N}$. $62^{\circ} \mathrm{W}$. of Lone Mountain summit 7,936 at altitude 6,900 ft. Nevada Formation, unit 2 near middle.

Locality M1044.-Bartine Ranch quadrangle; Lone Mountain, west side, 2,400 ft southwest of Lone Mountain summit 7,936 at altitude $7,280 \mathrm{ft}$. Nevada Formation, unit 1, upper beds.

Locality M29.-Bartine Ranch quadrangle; Lone Mountain, west side; $2,000 \mathrm{ft}$ south-southwest of Lone Mountain summit 7,936, above altitude of $7,200 \mathrm{ft}$. Nevada Formation, unit 2.

Locality M55.-Bartine Ranch quadrangle; Lone Mountain, west side. Same vicinity and zone as locality M29.

Locality M74.-Bartine Ranch quadrangle; Lone Mountain, south side, $3,800 \mathrm{ft} \mathrm{S}$. $7^{\circ} \mathrm{E}$. of Lone Mountain summit 7,936 at altitude $7,020 \mathrm{ft}$. Nevada Formation, unit 1.

Locality M1050.-Bartine Ranch quadrangle; Lone Mountain, south side, $4,000 \mathrm{ft} \mathrm{S.} 16^{\circ} \mathrm{E}$. of Lone Mountain summit 7,936 at altitude $6,960 \mathrm{ft} ; 1,200 \mathrm{ft}$ west of quadrangle boundary. Nevada Formation, unit 2, lowermost beds.

Locality M1046.-Bartine Ranch quadrangle; Lone Mountain, south side, $4,500 \mathrm{ft} \mathrm{S}$. $23^{\circ} \mathrm{E}$. of Lone Mountain summit 7,936 at altitude $7,000 \mathrm{ft} ; 700 \mathrm{ft}$ west of quadrangle boundary. Nevada Formation, unit 2.

Locality M1038.-Whistler Mountain quadrangle; Lone Mountain, south side; at west edge of quadrangle, 2,500 ft S. $36^{\circ} \mathrm{W}$. of summit 7,360 a.t altitude $6,890 \mathrm{ft}$. Nevada Formation, unit 2.

Locality M1049.-Whistler Mountain quadrangle; Lone Mountain, south side; $1,700 \mathrm{ft} \mathrm{S.} 34^{\circ} \mathrm{W}$. of summit 7,360 at altitude $6,920 \mathrm{ft} ; 600 \mathrm{ft}$ east of quadrangle boundary. Nevada Formation, unit 2, upper beds.

Locality M1037.-Whistler Mountain quadrangle; Lone Mountain, south side. Southeast pediment slope 1.5 miles north of Highway $50 ; 6.500 \mathrm{ft} \mathrm{S.} 11^{\circ} \mathrm{E}$. of summit 7,360 , altitude $6,420 \mathrm{ft}$. Nevada limestone in fault contact with Permian beds.

7. Southern Roberts Mountains

Locality M1042. - Roberts Creek Mountain quadrangle, Nevada; 1.75 miles north of Roberts Creek Ranch house, 0.75 mile east of Roberts Creek and 1.25 miles northwest of top of hill 7,504 (Pyramid Hill); top of knob, altitude $6,850 \mathrm{ft}$. Nevada Formation, unit 1 .

8. Northern Roberts Mountains

Locality M1072. - Roberts Creek Mountain quadrangle, Nevada. Near top of main spur south of Niel Creek, 1.4 miles S. $30^{\circ} \mathrm{W}$. of Western Peak and $1,000 \mathrm{ft}$ northeast of summit 8,168 , altitude $7,800 \mathrm{ft}$. Same as Merriam (1940, pl. 1) locality 1 (R 24). Lower Devonian.

Locality M1073. - Roberts Creek Mountain quadrangle, Nevada. In saddle 1,500 ft southeast of Cooper Peak at altitude 9,150 ft. Nevada Formation, unit 2. Same as Merriam (1940, pl. 1) locality 11 (R 1).

Locality M1054.-Same as locality M1073.

9. Northern Simpson Park Range

Locality M1074.-Walti Hot Springs quadrangle, Nevada. Foothills 0.5 mile southeast of Walti Ranch and west of McClusky Peak at middle of north edge sec. 4, T. 23 N., R. 48 E. Rabbit Hill Limestone; Lower Devonian. Col- lections by R. J. Roberts and R. E. Lehner, 1954.

Locality M1075.-Horse Creek Valley quadrangle, Nevada. Near mouth of Coal Canyon, east side along ridge top of summit 6,909, SE $1 / 4$ sec. 17, T. 25 N., R. 49 E. Rabbit Hill Limestone, Lower Devonian.

Locality M 1032.-Horse Creek Valley quadrangle, Nevada. East side of Coal Canyon, NW1/4 sec. 21, T. 25 N., R. 49 E. Rabbit Hill Limestone.

Locality M1076.-Horse Creek Valley quadrangle, Nevada. Near mouth of Coal Canyon, east side. Mostly float below ridge top of summit 6,909 and down slope to west. Rabbit Hill Limestone, Lower Devonian.

10. Southern Sulphur Spring Range (see fig. 5)

Locality M4.-Garden Valley quadrangle, Nevada. Prince of Wales mine area; $1,200 \mathrm{ft}$ southeast of mine and northwest of summit, 7,530 , altitude $7,300 \mathrm{ft}$ near old charcoal pit. Nevada Formation, unit 1.

Locality M69. - Garden Valley quadrangle, Nevada. Prince of Wales mine area. Foat material near locality M4.

Locality M1041. - Garden Valley quadrangle, Nevada. Prince of Wales mine area. Measured section through locality M4 southeast of mine, and northwest of summit 7,530. Nevada Formation, unit 1.

Locality M68. - Garden Valley quadrangle, Nevada. Prince of Wales mine area. Top of ridge east of mine at signal station 7,530. Nevada Formation, upper part of unit 1; Acrospirifer kobehana fauna.

Locality M67. - Garden Valley quadrangle, Nevada. East side of range 0.8 mile N. $65^{\circ} \mathrm{E}$. of Bailey Pass at altitude $6,520 \mathrm{ft}, 0.1$ mile south of road on top of spur. Nevada Formation, unit 1.

Locality M36. - Garden Valley quadrangle, Nevada. South of Bailey Pass 0.9 mile at altitude $7,200 \mathrm{ft}$ on north side of knob. Nevada Formation, unit 2 with Spirifer pinyonensis and Chonetes macrostriata.

Locality M198. - Garden Valley quadrangle, Nevada. Same as Locality M36.

Locality M197. - Garden Valley quadrangle, Nevada. $\mathrm{S} .12^{\circ} \mathrm{E}$. of Bailey Pass 0.8 mile on ridge top at altitude $7,080 \mathrm{ft} ; 1,000 \mathrm{ft}$ northeast of Locality M36. Rabbit Hill Lower Devonian fauna.

Locality M1031. — Garden Valley quadrangle; southern Sulphur Spring Range, 0.5 mile north-northwest of Romano Ranch house at east end of old lake terrace, altitude $6,000 \mathrm{ft} ; 500 \mathrm{ft}$ west of BM 5,836 . Nevada Formation, unit 2 with rugose corals.

Locality M1078. - Garden Valley quadrangle; southern Sulphur Spring Range 0.5 mile northwest of Romano Ranch house, south side of old lake terrace at altitude $6,000 \mathrm{ft} ; 1,000 \mathrm{ft}$ southwest of BM 5,836 and $500 \mathrm{ft}$ southwest of Locality M1031. Nevada Formation, unit 2.

Locality M1047. - Garden Valley quadrangle; southern Sulphur Spring Range about 0.5 mile west-northwest of Romano Ranch house, altitude $6,000 \mathrm{ft}$; about 0.5 mile southwest of BM 5,836. Nevada Formation, unit 2.

Locality MT079. - Garden Valley quadrangle; southern Sulphur Spring Range 1.5 miles N. $83^{\circ} \mathrm{W}$. of Romano Ranch house; $2,000 \mathrm{ft}$ northeast of summit 6,933 at altitude $6,560 \mathrm{ft}$. Nevada Formation, unit 2 with quartzite interbeds and fossils.

Locality M1080. - Garden Valley quadrangle; southern Sulphur Spring Range; S. $86^{\circ}$ E. of Mulligan Gap 1.2 miles on top of northeast spur, altitude $6,885 \mathrm{ft} ; 2,500$ 
ft northeast of 7,446 summit. Lower Devonian with rugose corals.

Locality M1081. - Garden Valley quadrangle; southern Sulphur Spring Range. In ravine 600 feet west of Locality M1080 at altitude $6,800 \mathrm{ft} ; 2,000 \mathrm{ft}$ northeast of 7,446 summit. Lower Devonian with Rabbit Hill Helderberg fauna.

Locality M1040. - Garden Valley quadrangle, Nevada; southern Sulphur Spring Range. South-southeast of Bailey Pass 1.1 miles near range top and $750 \mathrm{ft}$ northeast of summit 7,378, altitude 7,240 ft. Lower Devonian beds with Oriskany fossils.

Locality M56. - Garden Valley quadrangle, Nevada. Southernmost Sulphur Spring Range, 1.6 miles S. $25^{\circ}$ E. of Mulligan Gap, east side of ravine on top spur at altitude 6,690 ft. Nevada Formation, unit 1 with Oriskany fauna.

Locality M186. - Garden Valley quadrangle, Nevada. Southernmost Sulphur Spring Range, 1.7 miles S. $22^{\circ}$ E. of Mulligan Gap, east side of ravine, altitude 6,560 $\mathrm{ft}$, and $750 \mathrm{ft}$ southwest of Locality M56. Nevada Formation, Beacon Peak Dolomite Member with Rabbit Hill Helderbergian fauna.

Locality M1039. - Garden Valley quadrangle, Nevada. Southernmost Sulphur Spring Range. 1.5 miles southsoutheast of Mulligan Gap and $1,500 \mathrm{ft}$ west of 6,927 summit on east side of ravine. Nevada Formation, unit 1.

Locality M1051. - Garden Valley quadrangle, Nevada. Southernmost Sulphur Spring Range. 1.25 miles southsoutheast of Mulligan Gap near top main spur at altitude $7,150 \mathrm{ft} ; 2,700 \mathrm{ft}$ south of summit 7,446 . Nevada Formation, unit 2.

Locality M1077. - Garden Valley quadrangle, Nevada. Southernmost Sulphur Spring Range; 1.3 miles S. $25^{\circ}$ $E$. of Mulligan Gap on east side of ravine at altitude $6,720 \mathrm{ft}$. Nevada Formation, unit 1, with Lower Devonian rugose coral fauna.

Locality M1082. - Garden Valley quadrangle, southernmost Sulphur Spring Range, east side. 1.2 miles due west of BM 5,867 on top spur at altitude $6,440 \mathrm{ft} ; 1,400$ $\mathrm{ft}$ east-northeast of summit 6,474. Lower Devonian Beacon Peak Dolomite Member with Rabbit Hill Helderberg fauna.

\section{North-central Great Basin}

1. Northern Sulphur Spring Range

Locality M1018. - Mineral Hill quadrangle, Nevada. Northwest of Union Summit in McColley Canyon. Lower beds of the McColley Canyon Member of the Nevada Formation of Carlisle and others (1957). Lower Devonian with rugose coral fauna.

Localities M1021 to M1025 inclusive.-Mineral Hill quadrangle, Nevada. Same general areas as locality M1018, in same stratigraphic unit. Lower Devonian with rugose corals.

2. Cortez Mountains

Locality M1083.-Cortez quadrangle, Nevada. Southeast side of Mt. Tenabo, east slope of the Cortez Mountains; northeast side of upper Horse Canyon, $1,000 \mathrm{ft}$ north, $700 \mathrm{ft}$ west of SE cor. sec. 4, T. $26 \mathrm{~N}$., R. 48 E., altitude $7,900 \mathrm{ft}$. Rabbit Hill Lower Devonian fauna with Syringaxon and Pleurodictyum.

\section{West-central Great Basin}

1. Northern Toquima Range

Locality M1150. - Wildcat Peak quadrangle, Nevada. SW $1 / 4$ sec. 16 , T. 16 N., R. 46 E., top of spur $1,600 \mathrm{ft}$ south of summit 7,188 and 2,800 ft east of Petes Canyon road. Rabbit Hill Limestone on Silurian graptolitebearing shale.

2. Toiyabe Range

Locality M1151.-Austin quadrangle, Nevada. SE1/4 sec. 36, T. 17 N., R. 42 E.; in first main canyon at range front 1 mile south of Reeds Canyon. Devonian coralbearing limestone.

\section{SELECTED REFERENCES}

Billings, Elkanah, 1858, New genera and species of fossils from the Silurian and Devonian formations of Canada: Canadian Naturalist, v. 3 , no. 6 , p. 419-444.

1859, On the fossil corals of the Devonian rocks of Canada West: Canadian Jour., n. s., v. 4, p. 97-140.

1874, On some new or little known fossils from the Silurian and Devonian rocks of Ontario: Canadian Naturalist, n. s., v. 7, p. 230-240.

Birenheide, Rudolf, 1962a, Die Typen der Sammlung Wedekind aus den Familien Cyathophyllidae und Stringophyllidae (Rugosa): Senckenbergiana Lethaea, v. 43, no. 2, p. 101-122.

-1962b, Revision der koloniebildenden Spongophyllidae und Stringophyllidae aus dem Devon: Senckenbergiana Lethaea, v. 43, no. 1, p. 41-99, 7 pls.

1964, Die "Cystimorpha" (Rugosa) aus dem Eifeler Devon: Senckenbergischen Naturf. Ges., Abh. 507, p. 1119,28 pls.

Butler, A. J., 1935, On the Silurian coral Cyathaxonia siluriensis M'Coy: Geol. Mag., v. 72, no. 849, p. 116-124, pl. 2.

Carlisle, Donald, Murphy, M. A., Nelson, C. A., and Winterer, E. L., 1957, Devonian stratigraphy of Sulphur Spring and Pinyon ranges, Nevada: Am. Assoc. Petroleum Geologists Bull., v. 41, no. 10, p. 2175-2191.

Chapman, E. J., 1893, On the corals and coralliform types of Paleozoic strata: Royal Soc. Canada Trans., v. 10, sec. 4, p. 39-48.

Chernyschev, B. B., 1941, Silurian and Lower Devonian corals from the Tareia River Basin (Southwest Taimir): Trud. Arktick. Inst., v. 158, p. 9-64, 14 pls. (Russian and English).

Dybowski, W. N., 1873, Monographie der Zoantharia sclerodermata rugosa aus der Silurformation Estlands, NordLivlands und der Insel Gotland: Dorpat, Estonia. Also in Archiv. Naturkunde Liv-, Ehst-, und Kurlands, ser. 1, v. 3,274 p., 5 pls., v. 5 , no. 3 , p. $257-414$, pls. 1,2 (1873); no. 4, p. 415-532, pls. 3-5 (1874).

Edwards, H. M., and Haime, Jules, 1850-54, A monograph of the British fossil corals: London, Paleontological Soc., 322 p., 72 pls.

-1851, Monographie des polypiers fossiles des terrains palaeozoiques précédée d'un tableau général de la classification des Polypes: Mus. Histoire Nat., Paris, Archives, v. 5,502 p., 20 pls.

Ehlers, G. M., and Stumm, E. C., 1951, Billingsastraea: Pt. 4 of Corals of the Middle Devonian Traverse group of Michigan: Michigan Univ. Mus. Paleontology Contr., v. 9, no. 3, p. 83-92, pls. 1-3. 
1953, Species of the tetracoral genus Billingsastraea from the Middle Devonian of New York and other regions: Buffalo Soc. Nat. Sci. Bull., v. 21, no. 2, p. 1-11, pls. 1-6.

Erben, H. K., 1960, Primitive Ammonoidea aus dem Unterdevon Frankreiches und Deutschlands: Neues Jahrb. Geol. u. Paläontol., v. 110, p. 1-128, pls. 1-6.

Etheridge, Robert, Jr., 1911, The Lower Palaeozoic corals of Chillagoe and Clermont, pt. 1: Queensland Geol. Survey Pub. 231, p. 1-8, Pls. A-D.

Fenton, C. L., and Fenton, M. A., 1924, The stratigraphy and fauna of the Hackberry stage of the upper Devonian: Michigan Univ. Mus. Geology Contr., v. 1, 260 p., 45 pls.

Flügel, H., and Free, B., 1962, Laccophyllidae (Rugosa) aus dem Greifensteiner Kalk (Eiflium) von Wiede bei Greisenstein: Palaeontographica, v. 119, no. A, (PaläozologieStratigraphie) p. 222-247, pl. 41.

Frech, Fritz, 1886, Die Cyathophylliden und Zaphrentiden des Oberdevons in Deutschland: Palaeont. Abh., v. 3, no. 3, p. 115-234, 8 pls.

Fromentel, E. G. de, 1861, Introduction a l'étude des Polypiers fossils: Paris, $357 \mathrm{p}$.

Geinitz, H. B., 1846, Grundriss der Versteinerungskunde: Dresden, 815 p., 28 pls.

Glinski, Alfons, 1955, Cerioide Columnariidae (Tetracoralla) aus dem Eiflium der Eifel und des Bergischen Landes: Senckenbergiana Lethaea, v. 36, no. 1-2, p. 73-114.

1957, Taxionomie und Stratigraphie einiger Stauriidae (Pterocorallia) aus dem Devon des Rheinlandes: Senckenbergiana Lethaea, v. 38, p. 83-108.

Goldfuss, G. A., 1826-33, Petrefacta Germaniae, Bd. 1: Dusseldorf, Arnz and Co., 252 p., 71 pls.

Grabau, A. W., 1917, Stratigraphic relationships of the Tully limestone and the Genessee shale in Eastern North America: Geol. Soc. American Bull., v. 28, p. 945-958.

1928, Paleozoic corals of China, Part 1, Tetrasepta; Second contribution to our knowledge of the streptelasmoid corals of China and adjacent territories: Paleontologia Sinica, ser. B, v. 2, fascicle 2, p. 1-175, 6 pls.

Gürich, Georg, 1896, Das Palaeozoicum im des polnischen Mittelgebirge: Russ.-Kais. Min. Gesell. St. Petersburg, Verhandl., ser. 2, v. 32, 539 p., 15 pls.

Hague, Arnold, 1892, Geology of the Eureka district, Nevada: U.S. Geol. Survey Mon. 20, 419 p. (with an atlas).

Hall, James, 1876, Illustrations of Devonian Fossils; corals of the upper Helderberg and Hamilton groups: New York [State] Geol. Survey, Paleontology, 7 p., 136 pls.

1882, Description of the fossil corals from the Niagara and upper Helderberg groups: 35th Ann. Rept. New York State Mus. Nat. History, p. 407-464, pls. 23-30, (advance sheets).

-1883, Spergen Hill fossils, Paleontology: Indiana Dept. Geol. Nat. History, 12th Ann. Rept. for 1882, p. 319-375, 32 pls.

Hill, Dorothy, 1935, British terminology for rugose corals: Geol. Mag., v. 72, no. 857, p. 481-519, 21 figs.

1936, The British Silurian rugose corals with acanthine septa: Royal Soc. London Philos. Trans., ser. B, no. 534, v. 226 , p. $189-217,2$ pls.

1938, Euryphyllum: a new genus of Permian zaphrentoid rugose corals: Royal Soc. Queensland Proc., v. 49, p. 23-38.

1939, The Devonian rugose corals of Lilydale and Loyola, Victoria: Royal Soc. Victoria Proc., (new series), v.
51, pt. 2, p. 219-256, 4 pls.

1956, Rugosa, in Moore, R. C., ed., Treatise on invertebrate paleontology, Part F-Coelenterata: New York and Lawrence, Kansas, Geol. Soc. America and Kansas Univ. Press, p. F233-F324.

Holmes, M. E., 1887, The morphology of the carinae upon the septa of rugose corals: Boston, Bradlee Whidden, p. 7-31, pls. 1-16.

House, M. R., 1962, Observations on the ammonoid succession of the North American Devonian: Jour. Paleontology, v. 36, no. 2, p. 247-284.

House, M. R., and Pedder, A. E. H., 1963, Devonian goniatites and stratigraphical correlations in western Canada: Palaeontology, v. 6, pt. 3, p. 491-539, 8 pls.

Hudson, R. G. S., 1944, Lower Carboniferous corals of the genera Rotiphyllum and Permia: Jour. Paleontology, v. 18 , no. 4, p. 355-362, pls. 56, 57.

Johnson, J. G., 1962a, Brachiopod faunas of the Nevada formation (Devonian) in central Nevada: Jour. Paleontology, v. 36 , no. 1 , p. 165-169.

-1962b, Lower Devonian-Middle Devonian boundary in central Nevada: Am. Assoc. Petroleum Geologists Bull., v. 46 , no. 4 , p. $542-546$.

1966a, Middle Devonian brachiopods from the Roberts Mountains, central Nevada: Palaeontology, v. 9, pt. 1, p. $152-181,5$ pls.

1966b, Two new spiriferid brachiopod genera from the Lower Devonian of Nevada: Jour. Paleontology, v. 40, no. 5, p. 1043-1050, 3 pls.

-1966c, Parachonetes, a new Lower and Middle Devonian brachiopod genus: Palaeontology, v. 9, pt. 3, p. 365-370, 2 pls.

Johnson, M. S., and Hibbard, D. E., 1957, Geology of the Atomic Energy Commission Nevada Proving Grounds area, Nevada: U.S. Geol. Survey Bull. 1021-K, p. 333-384.

Jones, O. A., 1930, A revision of some Paleozoic coral genera and species [abs.]: Cambridge Univ., Abs. Dissert. Academical Year 1928-29, p. 35-36.

Kato, Makoto, 1963, Fine skeletal structure in Rugosa: Hokkaido Univ. Fac. Sci. Jour., ser. 4, v. 11, no. 4, p. 571-630, 3 pls., 19 text figs.

Lang, W. D., and Smith, Stanley, 1927, A critical revision of the rugose corals described by William Lonsdale in Murchison's "Silurian system": Geol. Soc. London Quart. Jour., v. 83, p. 448-491, pls. 34-37.

1934, Ludwig's "Corallen aus Paläolitischen Formationen" and the Genotype of Disphyllum de Fromentel: Annals and Mag. Nat. History, ser. 10, v. 13, no. 73, p. 78-81.

1935, Cyathophyllum caespitosum Goldfuss, and other Devonian corals considered in a revision of that species (with discussion): Geol. Soc. London Quart. Jour., v. 91, no. 364 , pt. 4 , p. 538-590, pls. 35-37.

Lang, W. D., Smith, Stanley, and Thomas, H. D., 1940, Index of Palaeozoic coral genera: London, British Museum (Nat. History), 231 p.

Lenz, A. C., 1961, Devonian rugose corals of the lower Mackenzie Valley, Northwest Territories, in Geology of the Arctic, v. 1: Toronto, Ontario, Univ. Toronto Press, p. 500-514.

Lesueur, C. A., 1821, Description de plusieurs animaux appartenant aux polypiers lamellifères de Lamarck: [Paris] Mus. Histoire Nat., Mém., v. 6, p. 271-299, pls. 15-17. 
Lindström, Gustav, 1882, Anteckningar om Silurlagren på Carlsöarne: Öfvers. Kgl. Vetenskapsakad Förhandl., v. 39 (1882), no. 3, p. 5-30.

McAllister, J. F., 1952, Rocks and structure of the Quartz Spring area, northern Panamint Range, California: California Div. Mines Spec. Rept. 25, 38 p.

McCoy, Frederick, 1850, On some new genera and species of Silurian Radiata in the collection in the University of Cambridge: Annals and Mag. Nat. History, ser. 2, v. 6, p. 270-290.

McLaren, D. J., 1959, A revision of the Devonian coral genus Synaptophyllum Simpson: Canada Geol. Survey Bull. 48, p. 15-33, pls. 7-10.

Markov, K. V., 1926, Note sur Arcophyllum, un nouveau genre de coraux Rugosa: Ann. soc. paleont. Russie, v. 5, p. 4960 , pl. 3.

Meek, F. B., 1877, Paleontology: U.S. Geol. Explor. 40th Parallel, v. 4, pl. 1-197, pl. 2.

Merriam, C. W., 1940, Devonian stratigraphy and paleontology of the Roberts Mountains region, Nevada: Geol. Soc. America Spec. Paper 25, 114 p., 16 pls. 1963, Paleozoic rocks of Antelope Valley, Eureka and Nye Counties, Nevada: U.S. Geol. Survey Prof. Paper 423, p. 1-67.

Miller, A. K., 1938, Devonian ammonoids of America: Geol. Soc. America Spec. Paper 14, 262 p. 39 pls.

Moenke, Maria, 1954, Rodzaj Hexagonaria w dewonie Gor Swietokrzyskich: Acta Geol. Polonica, v. 4, p. 445-483, 2 pls.

Nicholson, H. A., and Lydekker, Richard, 1889, A manual of paleontology [3rd ed.]: Edinburgh and London, $885 \mathrm{p}$.

Nolan, T. B., 1935, The Gold Hill mining district, Utah: U.S. Geol. Survey Prof. Paper 177, 172 p.

Nolan, T. B., Merriam, C. W., and Williams, J. S., 1956, The stratigraphic section in the vicinity of Eureka, Nevada: U.S. Geol. Survey Prof. Paper 276, 77 p.

O'Connell, Marjorie, 1914, Revision of the genus Zaphrentis: New York Acad. Sci. Annals, v. 23, p. 177-192.

Ogilvie, M. M., 1897, Microscopic and systematic study of madreporarian types of corals: Royal Soc. London Philos. Trans., ser. B, v. 187, p. 83-345.

Oliver, W. A., Jr., 1958, Significance of external form in some Onondagan rugose corals: Jour. Paleontology, v. 32, no. 5, p. 815-837, pls. 104-106.

1960a, Rugose corals from reef limestones in the Lower Devonian of New York: Jour. Paleontology, v. 34, no. 1, p. 59-100, pls. 13-19.

1960b, Devonian rugose corals from northern Maine: U.S. Geol. Survey Bull. 1111-A, p. 1-23, pls. 1-5.

$1960 \mathrm{c}$, Coral faunas in the Onondaga limestone of New York, in Geological Survey research 1960: U.S. Geol. Survey Prof. Paper 400-B, p. B172-B174.

-1964, The Devonian colonial coral genus Billingsastraea and its earliest known species: U.S. Geol. Survey Prof. Paper 483-B, p. B1-B5, 2 pls.

1968, Some aspects of colony development in corals, in Paleobiological aspects of growth and development, a symposium: Paleont. Soc. Mem. 2 (Jour. Paleontology, v. 42, no. 5, supp.), p. 16-34.

Pedder, A. E. H., 1964, Correlation of the Canadian Middle Devonian Hume and Nahanni Formations by tetracorals: Paleontology, v. 7, pt. 3, p. 430-451, pls. 62-73.

-1965, A revision of the Australian Devonian corals previously referred to Mictophyllum: Royal Soc. Victoria
Proc., v. 78, pt. 2, p. 201-220, pls. 30-34.

Počta, Philippe, 1902, Anthozaires et Alcyonaires, v. 2 of Barrande, Joachim, Recherches Paléontologiques, pt. 1 of $\mathrm{v}$. 8 of Systêm silurien du centre de la Boheme: Prague, 347 p., pls. 20-118.

Prantl, Ferdinand, 1938, Some Laccophyllidae from the Middle Devonian of Bohemia: Annals and Mag. Nat. History, ser. 11, v. 2 , no. 7 , p. 18-41, 3 pls.

Różkowska, Maria, 1960, Blastogeny and individual variations in tetracoral colonies from the Devonian of Poland: Acta Palaeontologica Polonica, v. 5, no. 1, p. 1-64.

Schindewolf, O. H., 1942, Zur Kenntniss der Polycoelien und Plerophyllen, eine Studie über den Bau der "Tetrakorallen" und ihre Beziehungen zu den madreporarien: Reichsamt. Bodenf., Abh., Heft 204, 324 p., 36 pls.

Schlüter, C. A. J., 1889, Anthozoen des rheinischen MittelDevon: Abh. geol. Specialkarte Preuss. Thüring. Staat., v. 8 , no. 4 , p. $259-465$, pls. $1-16$.

Schouppé, Alexander von, 1958, Revision des Formenkreises um Phillipsastraea d'Orb., "Pachyphyllum" E.\& H., Macgeea (Webst.), "Thamnophyllum” Pen, Peneckiella Soshk. und verwandter Formen.: Neues Jahrb. Geologie u. Paläontologie Abh., v. 106, no. 2, p. 139-243, pls. 5-6.

Simpson, G. B., 1900, Preliminary description of new genera of Paleozoic rugose corals: New York State Mus. Bull. 39, v. 8, p. 199-222.

Sloss, L. L., 1939, Devonian rugose corals from the Traverse beds of Michigan: Jour. Paleontology, v. 13, no. 1, p. 5273,4 pls.

Smith, Stanley, 1945, Upper Devonian corals of the Mackenzie River region, Canada: Geol. Soc. America Spec. Paper 59,126 p., 35 pls.

Smith, Stanley, and Lang, W. D., 1930, Descriptions of the type specimens of some Carboniferous corals of the genera "Diphyphyllum," "Stylastraea," Aulophyllum and Chaetetes: Annals and Mag. Nat. History, ser. 10, v. 5, p. 177-194.

Sorauf, J. E., 1967, Massive Devonian Rugosa of Belgium: Kansas Univ. Paleont. Contr., Paper 16, 41 p., 19 figs.

Stainbrook, M. A., 1946, Corals of the Independence Shale of Iowa: Jour. Paleontology, v. 20, no. 5, p. 401-427, pls. 57-61.

Stewart, G. A., 1938, Middle Devonian corals of Ohio: Geol. Soc. America Spec. Paper 8, 120 p., 20 pls.

Stewart, J. H., and McKee, E. H., 1968, Favorable areas for prospecting adjacent to the Roberts Mountains thrust in southern Lander County, Nevada: U.S. Geol. Survey Circ. 563, $13 \mathrm{p}$.

Stumm, E. C., 1937, The lower Middle Devonian tetracorals of the Nevada limestone: Jour. Paleontology, v. 11, no. 5, p. $423-443,3$ pls.

1938, Upper Middle Devonian rugose corals of the Nevada limestone: Jour. Paleontology, v. 12, no. 5, p. 478-485, 2 pls.

1940, Upper Devonian rugose corals of the Nevada limestone: Jour. Paleontology, v. 14, p. 57-67, 2 pls.

1948a, Lower Middle Devonian species of the Tetracoral genus Hexagonaria of east-central North America: Michigan Univ. Mus. Paleontology Contr., v. 7, no. 2, p. $7-49$.

1948b, A revision of the aulacophylloid tetracoral genus Odontophyllum: Michigan Univ. Mus. Paleontology Contr., v. 7, no. 3, p. 51-61, pls. 1, 2.

1949 , Revision of the families and genera of the Devo- 
nian tetracorals: Geol. Soc. America Mem. 40, 92 p., 25 pls. 1963, Corals of the Traverse Group of Michigan-pt. 11, Tortophyllum, Bethanyphyllum, Aulacophyllum, and Hallia: Michigan Univ. Mus. Paleontology Contr., v. 18, no. 8, p. 135-155, 10 pls.

1964, Silurian and Devonian corals of the Falls of the Ohio: Geol. Soc. America Mem. 93, 184 p., 2 figs., 80 pls.

Torley, K., 1933, Ueber Endophyllum bowerbanki M. Ed. u. H.: Deutsch. Geol. Gesell. Zeitschr., v. 85, no. 8, p. 630 $633,1 \mathrm{pl}$.

Vollbrecht, E., 1922, Uber den Bau von Cosmophyllum nov. gen.: Gesell. Beförd. gesamt. Naturwiss. Marburg Sitzungsber., v. 56, Jahrg. 1921, no. 1, p. 17-34, 14 text figures.

1926, Die Digonophyllinae aus dem Unteren MittelDevon der Eifel: Neues Jahrb. Min., Geologie u. Paläontologie Abh., v. 55, ser. B, p. 189-273, pls. 8-16.

Walcott, C. D., 1884, Paleontology of the Eureka district [Nev.]: U.S. Geol. Survey Mon. 8, 298 p.

Wang, H. C., 1950, A revision of the Zoantharia Rugosa in the light of their minute skeletal structures: Royal Soc. London Philos. Trans., ser. B, no. 611, v. 234, p. 175-246, pls. 4-9.

Wedekind, Rudolf, 1923, Die Gliederung des Mitteldevons auf Grund von Korallen: Gesell. Beförd. gesamt. Naturwiss. Marburg Sitzungsber., Jahrg. 1922, no. 1, p. 24-35, 7 text figures.

-1924, Das Mitteldevon der Eifel. Eine biostratigraph- ische Studie. 1 Teil. Die Tetrakorallen des unteren Mitteldevon: Gesell. Beförd gesamt. Naturwiss. Marburg Schr., v. 14, pt. 3, p. 1-91.

1925, Das Mitteldevon der Eifel. 2 Teil. Materialen zur Kenntnis des mittleren Mitteldevon: Gesell. Beförd. gesamt. Naturwiss. Marburg Schr., v. 14, pt. 4, p. 1-85.

1926, Die devonisch Formation, in Salomon, W., Grundzüge der Geologie: Stuttgart, v. 2, pt. 1, p. 195.

1927, Die Zoantharia Rugosa von Gotland (bes. Nordgotland): Sveriges Geol. Undersökning, ser. $\mathrm{Ca}$, no. 19, 94 p., 30 pls.

Wedekind, Rudolf, and Vollbrecht, E., 1931, Die Lytophyllidae des mittleren Mitteldevon des Eifel: Palaeontographica, v. 75 , p. $81-110$, pls. $15-46$.

1932, Die Lytophyllidae des mittleren Mitteldevon des Eifel: Palaeontographica, v. 76, p. 95-120, pls. 9-14.

Wells, J. W., 1937, Individual variation in the rugose coral species, Heliophyllum halli M. E. \& H.: Palaeontographica Americana, v. 2, no. 6, 22 p., 1 pl.

Whiteaves, J. F., 1892, The fossils of the Devonian rocks of the islands, shores or immediate vicinity of Lakes Manitoba and Winnipegosis: Canada Geol. Survey, Contr. Canadian Paleontology, v. 1, p. 255-359.

Wilson, E. C., 1963, An evaluation of the genomorph concept: Systematic Zoology, v. 12, no. 2, p. 83-90.

Yoh, S. S., 1937, Die Korallenfauna des Mitteldevons aus der Provinz Kwangsi, Südchina: Palaeontographica, v. 87, pt. A, Lf. 1-2, p. 45-76, pls. 4-9. 


\section{INDEX}

[Italic page numbers indicate major references]

Page

abditum, Endophyllum Acanthophyllum $\ldots \ldots \ldots-\ldots . . . . . . .21,25,70$ Acinophyllum Acknowledgments

Syringaxon …-... affinis, Billingsastraea ….............................. 30,64 Age, coral zone B .......................................... 32 coral zone $\mathrm{C}$...................................... 30, 32 coral zone D ....................................... 30 coral subzone $D_{1} \ldots \ldots$

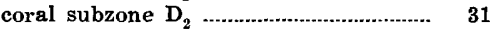
coral zones, distant regions __............. 29 Early Devonian ......................... 29, 32, 33 Early middle Devonian .................. 29 Late Silurian …_.......................... 33

Nevada Formation, unit 2 ...................... 31 aggregatum, Cystiphylloides ………........... 64,65 Agoniatites nevadensis ……....................... 30 Alaska …................................ 29, 31, 56, 69 Alberto Islands, Alaska ………………...... 70 Alleynia ………........................................ 39 (Nicholsonia) …...................................... 39 americanum, Cystiphylloides ………........... $\quad 66$ Ammonoids …………………………... 18, 30, 31 Amphipora ………………………... 9, 15, 17, 22 Amplexus invaginatus .................................... 42 lonensis .............................................. 42, 43

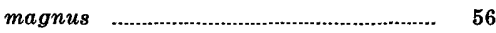
nevadensis _..._. Anastrophia verneuili ................................... 29 Andy Hills …............................ 32 Antelope Range ……...... 6, 43, 52, 56, 62, 63, 68 Antelope-Roberts Mountains facies belt .... 1 ,

$6,13,15,17,29$ antelopensis, Bethanyphyllum ...... 21, 33, 53, 54 Aphroidophyllum .................................. 58, 64 arachne, Billingsastraea .............................. 64 Billingsastraea nevadensis.. $34,38,62,63,64$

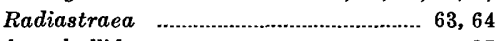

Arachnophyllidae ........................................... 37

Arcophyllum $\quad 30,34,36,67,68,70$ dachsberg $i$...................................... $\quad 70$ kirki _................................................. 30 limbatum ......................................... 70 typus ….............................................. 68

(Arcophyllum) dachsbergi, Mesophyllum.. 70 kirki, Mesophyllum .................. 21, 30, 34, 69 limbatum, Mesophyllum ....................... 70 Mesophyllum ...................................... 67

Acrospirifer kobehana... 13, 20, 24, 32, 33, 52, 66

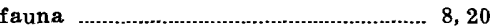
zone -.r. sp ............................................. 20, 32, 50 arenosus, Costispirifer .................... 8, 11, 17, 19 $20,23,29,31,32,33,49$

Assemblage, brachiopod .............................. 31 coral-brachiopod-tribolite $\quad$....................... $\quad 24$

astreiformis, Stauria ................................... 45

Atelophyllum .............................................. $\quad 67$

Atrypa nevadana .......................................... 21

Atrypa Peak .................................................. 42

Aulacophyllum .......................... 24, 32, 33, 46, 53 convergens .............................................. 47 sp. c .
Page

Austin quadrangle

Australophyllum _.......... 28, 29, 33, 34, 57, 61, 70

cyathophylloides ................................... 57 landerensis .........................20,23,33,34,57

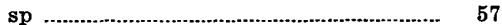

\section{B}

Barrandeophyllum perplexum

Bartine Ranch quadrangle ........................... 5

Bay State Dolomite Member ........... 9, 13, 15, 16,

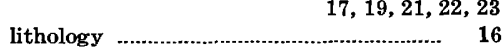
Beacon Peak Dolomite Member ......... 6, 8, 9, 11, $15,17,19,23,28,31,40$

lithology

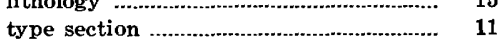

Beechwood Limestone ..................................... 47

Belmont mine .................. 19, 22, 25

Bensberg, Germany ........................................ 60

Bethanyphyllidae ................ 17, 27, 29, 30, 33, 58

Bethanyphyllum ........................... 24, 33, 53, 54 antelopensis ….......................... 21, 33, 53, 54 lonense ................................................... 34,55

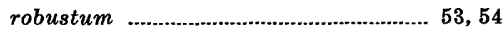

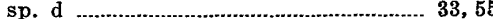

Billingsastraea .......................... 20, 23, 24, 31, 32 $34,35,37,38,58,61,62$

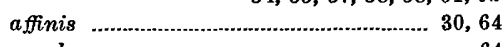

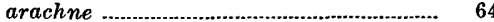

billingsi nevadensis ................................ 63 nevadensis ......... 21, 30,31, 34, 38,61, 62, 63 arachne ....................... $34,38,62,63,64$

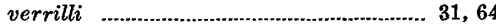

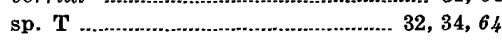
(Billingsastraea), Phillipsastraea ............... 62 billingsi nevadensis, Billingsastraea ............ 63 Biofacies, Breviphrentis ..................... 23 Hexagonaria-Sociophyllum .................. 23, 25

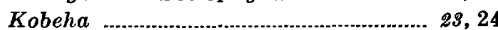

Papiliophyllum ................................... 23, 24 Phillipsastraea ............................. 19, 23, 25 Syringaxon …....................................... 29 Biofacies aspects, Devonian corals .............. 22 Biofacies indicator .............................. 5,23 Bioherms .................................... 9, 22, 23, 25

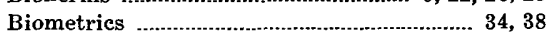

Biostratigraphy, central Great Basin Devonian 17 Birenheide, Rudolf, cited ............................. 67,68 bowerbanki, Endophyllum ....................... 56 Brachiopods ............................ 5, 9, 13, 15, 16 $17,18,19,20,23,24,25,29,30,50$ spiriferoid .......................................... 17 Branik Limestone, Bohemia ........................ 39

Breviphrentis .......... 24, 27, 33, 38, 41, 42, 44, 45 invaginatus ................... 30,42, 43, 44, 46, 56 kobehensis .................................... 29 (Breviphrentis) invaginatus, Siphonophrentis ............ 21, 30, 32 , $33,38,42,45,54,56$ kobehensis, Siphonophrentis ............ 20, 30

Siphonophrentis $33,42,43,66$ Breviphyllum
Breviphyllum-Continued lonensis breviseptatum, Eurekaphullum Bryozoans ................................................... 23 Bücheler Schichten ................................... 45, 46 Bush Creek ............................................. 30

\section{C}

caespitosum, Cyathophyllum ....................... 58

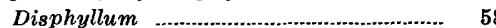

Calcarenite ......................................... 8, 11, 31 Calceola beds, Russia .......................... 68, 70 Caledonian Revolution ................................ 27 Canada, western ...........................29, 31, 56, 64 Carlin, Nev ................................................ 20, 31 Caryophyllia gigantea ................................ 41 castanea, Leiorhynchus .......................... 13, 16 Central Peak .............................................. 20

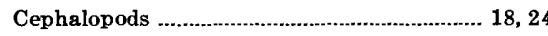
orthoceratid ........................................ 23, 24

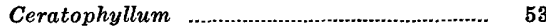

Charcoal Gulch ............................................. 21

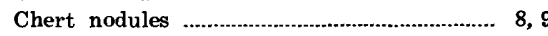

Chewelah area ............................................. 31

Chonetes macrostriata .................... 20, 21, 32, 52

Chonophyllidae ..................... 28, 33, 37, 38, 41, 55 Conophyllum ................................................ 55 Cladocora goldfussi ....................................... 58

Clams ........................................................... 24

Clark County, Nev .................................. 32, 52 Clermont, Australia .................................. 57 Coal Canyon ........................... 17, 19, 28, 33, 40 Cockalorum Wash quadrangle ...................... Coeymans Limestone, New York .... 23, 30, 42, 44 coeymanensis, Gypidula ......................20, 29, 50 Collection procedure ....................................... 4, 4 Columnaria ................................... 45, 58,61 (Cyathophylloides) disjuncta ............... 45 Combs Peak ......................................... 30, 54 Compressiphyllum .................................. 41 Confusion Range ............................................ 27

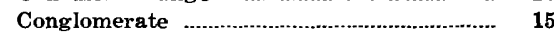
Conodonts ....................................... 17, 19, 31 Contact Gulch ........................................ 8,20 convergens, Aulacophyllum .......................... 47 Odontophyllum ........................................ 47 Convergent genera .................................. 34 cooperi, Trematospira ................................ 29 Copenhagen Canyon ...................................17, 19 Coral assemblage, Gotlandian ................. 17, 19, 28 Coral assemblages, succession ..................... 27 Coral distribution, Devonian ........................ 22 Coral evolution, biologic factors ............... 25, 27

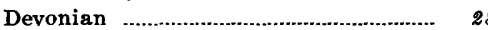
geologic factors .................................... 25, 27 Late Silurian ........................................ 27, 28 related to faunal migration .................. 25 related to geologic changes ....................... 25

Coral fauna, Ludlovian ................................... 19 Onondaga Limestone .............................. 25 Rabbit Hill ............................................ 19 Coral Gulch ................................................... 8 Coral Ridge ........................................... 13 Coral subzones .............................. 19, 20, 30, 31 Coral succession, related to faunal migration related to geologic change 25 
Coral $\quad$ Page Coral zone A $8,11,17,18,19,23,28,29,31$

B $\quad 8,11,17,18,19,20,23,25,28,29,32$

C …_........ $8,11,13,17,18,19,20,23,24,25$, $28,29,32,42,44,47,5$

D _.......... $8,11,13,17,18,19,20,21,22,23$ $24,25,28,30,32,42,43,44,45$

E ….......... $3,17,18,19,21,25,28,29,33,45$

F ….......... $5,9,13,15,16,17,18,19,20,21$. $22,23,25,28,31$ correlation

G $\ldots \ldots \ldots . . . . . . .15,16,17,18,19,21,22,28$ H …............................. 17, 18, 19, 22, 25, 28 I …....................... $17,18,19,22,23,25,28$

Corals ................................................. 5, 9, 23 Carboniferous ........................................ 38 colonial .............................. 21, 29, 31, 37, 38 dissepiments ..................................... 36

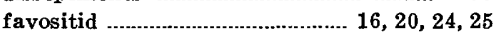

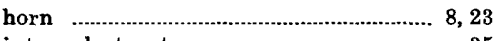
internal structures ................................. 35

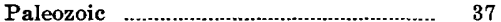

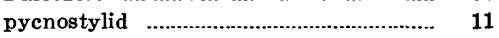
rugose …....... $9,13,15,16,17,19,21,22,25$ septa $\ldots \ldots \ldots . . . . . .35,37,38$ septal carinae ...................................... 36,37 septal stereozone ................................... 37 Silurian ....................................................... 37 skeletal features ..................................... 34 solitary .............. $21,24,25,35,36,37,38$ stereoplasmic deposits .......................... 37 tabulae ............................................... 36,37 tabulate ............. 18, 19, 20, 23, 24, 25, 29, 36 Cordilleran Belt ................... 25, 29, 30, 31, 37, 56 corniculum, Streptelasma.

Correlation, coral subzone $\mathbf{D}_{2}$...

coral zones, Cordilleran Belt distant regions

Cortez Mountains

Desert Range

Funeral Mountains

Hot Creek Range

Hume Formation

Nahanni Formation

Nevada Formation unit 1

unit 2

north-centr

northern Inyo Mountains

northern Panamint Mountains ....................

northern Sulphur Spring Range .......

Oriskany

Rabbit Hill Limestone

Ranger Mountains

south-central Great Basin

southern Great Basin

Toiyabe Range

Tuscarara Mountains, southern west-central Great Basin

Cortez Mountains

Cosmophyllum

$68,69,70$ dachsbergi ….................................... 30, 70

Costispirifer $13,19,20,23,29$ arenosus $8,11,17,19,20$

$23,29,31,32,33,49$

Crinoids ....................................... 8, 21, 23, 24 curviseptatum, Grypophyllum ..................... 53 Cyathaxonia siluriensis ............................... $\quad 39$ Cyathophylloides

rhenanum

(Cyathophylloides) disjuncta, Columnaria. cyathophylloides, Australophyllum .............. 57 Spongophyllum ……............................. 57

Cyathophyllum ................................... 21, 25, 29 caespitosum ............................................... 58

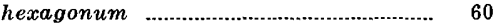
lonense .................................................. 53,54 (Moravophyllum)
Cyathophyllum-Continued robustum ............................................... 53

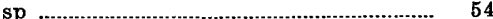
cycloptera, Howellella .................................. 19, 29

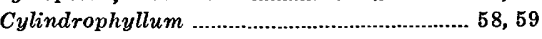
Cyrtina

Cyrtospirifer beds, Devils Gate .................... 19, 22 Cyrtospirifer zone ......................................... 22 Cystiphyllidae ............................................ 65 Cystiphylloidae .......................... 29, 33, 34, 35, 64 Cystiphylloides ...........6, 21, 24, 25, 33, 34, 65, 68

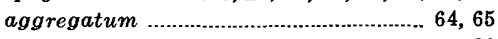
americanum …........................................ 66

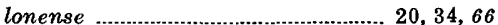
robertsense …................................ 21, 34,65

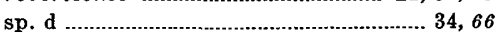
(Cystiphylloides), Mesophyllum ................ 65

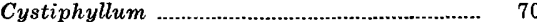

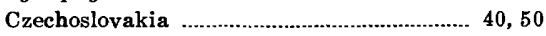

dachsbergi, Arcophyllum ............................. 70 Cosmophyllum ................................... 30, 70 Mesophyllum (Arcophyllum) ................ $\quad 70$

Dalmanites …............................................... 20 meeki ......................................... 21, 32, 52 defectum, Mesophyllum ................................ 67

Dendrostella ............................................... 33, 45 disjuncta ............................................... 46 praerhenana ............................................ 46

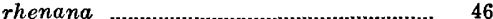
romanensis ..................................... 21, 33, 45 (Dendrostella) praerhenana, Favistella .... 45 rhenana, Favistella ................................. 45 Descriptive paleontology ............................... $8 s$ Desert Range ........................................... 32, 43

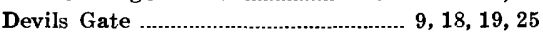
Devils Gate Limestone ..................... 6, 9, 15, 17, $21,22,25,28,29,60$ lithology ............................................. 9, 17 type area ................................................. 22 type section ......................................... 19 Devils Gate Pass ........................................... $\quad 22$ Dialytophyllum

Diamond Mountains

$5,6,8,9,13,15$ $18,19,21,22,23,27$

Diamond Mountains facies belt ........... 1, 6, 8, 9, $13,15,17,29$

Diamond Valley $17,24,29,30,33$

Digonophyllida $34,35,36,38,65,67,71$

Digonophyllinae $34,67,68$

Digonophyllum (Digonophyllum) $21,25,65,69$

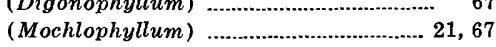
(Digonophyllum), Digonophyllum ............. 67 Dimorphism Disconformity ........................................... 8, 19, 27 disjuncta, Columnaria (Cyathophylloides).. 45 Dendrostella ........................................ 46

Disphyllidae ............. $17,29,33,34,38,58,60,61$ Disphyllum ........................... 21, 22, 24, 34, 58 caespitosum …....................................... 58 eurekaensis …................... 21, 34, 59, 66 goldfussi ................................................... 59

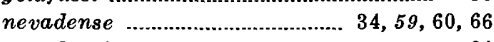
nevadensis

Dissepimentarium

Dissepiments ..

Dobbin Summit ...................................... 17, 19, 40

Dolomite ............... 8, 9, 13, 15, 19, 20, 27, 28, 32 diagenetic ......................................... 3, 23

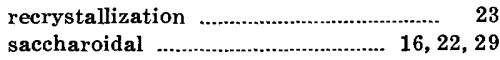

Douglas Creek, Australia ........................... $\quad 57$ duplicatum, Zonophyllum .................. 30, 70, 71
Page

Early Devonian coral zones .......................... 19 correlation ............................................... 29 Early middle Devonian coral zones ............ 19 correlation ................................................ 29 East Ridge ................................................... 11 Eifel district, Germany ........ 30, 58, 60, 67, 69, 70 Eightmile Well ............................................ 15 elegantulum, Ketophyllum .......................... 50 Papiliophyllum .. 20,24,32, 33, 46, 47, 50,66 Encrinite .............................................. 13, 15 Endophyllidae ......... 28, 33, 34, 37, 56, 58, 60, 61

Endophyllum ............................................ 57, 58 abditum ........................................... 56 bowerbanki ............................................... 56

Entelophylloides ................................................ 60

Entelophyllum ...................................... 28, 35

Erben, H. K., cited ......................................... 30

Eridophyllum ............................................... 59

Eureka, Nev .................... 27

Eureka County ........ 23, 43, 44, 46, 47, 50, 51, 52,

Eureka mining district,

$54,55,56,59,62,63,65,68$

Nevada ... 4, 5, 29, 32, 42, 43, 56, 71

Eureka Quartzite ........................................ 15 eurekaensis, Disphyllum .................... 21, 34, 59, 66 Eurekaphyllum ............................ 33, 47,50,52 breviseptatum ....................................... 33, 52 Eurekaspirifer pinyonensis ..................... 18, 21 expansum, Spongophyllum .......................... $\quad 59$

Fauna, brachiopod 31,32 coral coral zone A .................................. 19, 20, 28, 40 B …..........20,28,30,31, 46, 47, 49, 50 C …........... 20, 30, 31, 46, 50,52, 54, 66 D $20,21,27,31,32,41$, $46,56,61,62,64,66,68$ $E$
F $56,58,60,61,62,64,67$ G …............................................ 21

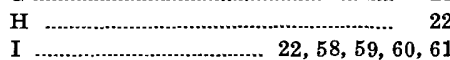
Funeral Mountains ................................. 33 Onondaga ............................................ 30

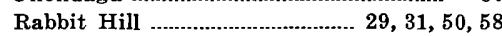
subzone $D_{1} \ldots . .20,21,30,47,52,54,55,56,71$ subzone $D_{2} \ldots . . . .21,30,46,54,55,56,58,59$, $60,61,62,63,64,66,67,70,71$ subzone $D_{3} \ldots \ldots \ldots \ldots \ldots . . . . . .21,30,55,62,67,70$ Trematospira

29

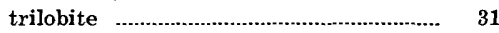
Faunal migration, related to

coral evolution …....................... 25

33,45

(Dendrostella) rhenana ........................ 45 praerhenana ..................................... 45

Favistina

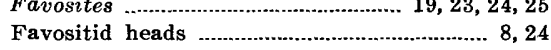
Fenstermaker Mountain .............................. 45 Fish Creek Range ......... 5, 6, 9, 15, 43, 45, 54, 71 flexum, Hexagonaria .................................... 62 Mesophyllum ............................................. 66 foerstei, Syringaxon …................... 19, 31, 33, 39 Foraminifera ….......................................... 34 Fossil Gulch ............................................. 8 Fossils, silicified ........................... 23, 24, 25, 34 Frasnes, Belgium ............................................. 60 Frazier Creek ................................................. 65 Frenchman Flat County, $\mathrm{Nev}$..................... $\quad 32$ Funeral Mountains ................................ 32, 43, 52

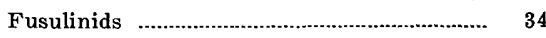




\section{G}

Page

Garden Valley Formation

15

Garden Valley quadrangle ……..................... 15, 2

Gazelle Formation ............................................. 60

Genomorph concept ............. 38

Geologic change, related to coral evolution ...................... 25

Geologic structure, Lone Mountain ........... 5

Germany ......... 58,67,70

Gerolstein, Eifel district ................................. 30, 70 gigantea, Caryophyllia ....................................... 41

Siphonophrentis

giganteum, Grypophyllum

Gold Hill mining district, Utah ...................... 27

goldfussi, Cladocora …................................... 58

Disphyllum - .

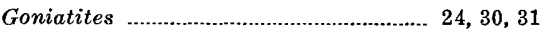

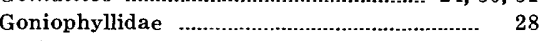

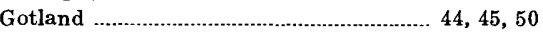

Gotland reef complex …-..-1- 22

Grande Grève Formation ............................ 30, 64

Graptolite beds ……........................... 5, 17, 19, 32

Grays Cany on ............................. 15, 43, 54, 56, 71

Great Basin, central ........................... 39, 43, 71

coral reference sections ........................ 6 correlation ………………………... 31, 32

Devonian Facies belts ............................ 6 faunas …............. 24, 53, 56, 57, 60, 67, 71 north-central .................................... 74 Rugosa, elassification ……..................... 33

south-central ……………………….... $7_{2}$

southern ......................................... 43, 71

west-central _............................. 74

Great Basin province .... 23, 25, 27, 29, 45, 62, 67

Green Springs quadrangle

Greifensteiner Kalk, Germany …………….... 40

Grypophyllum curviseptatum ……......-........... 53

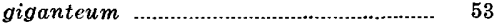
nevadense

Gypidula ………………………………. 29, 50 coeymanensis _...…......................... 20, 29, 50

loweryi …….................................. 20, 21, 52

H

haguei, Zonophyllum ..................... 21, 30,34, 71 Hallia insignis .............................................. 46 Hallidae …......... 17, 20, 24, 29, 30, 33, 37, 46, 53 Halliinae ..................................................... 33, 46 Halysites 11 Halysitids ……-..Hamilton Formation ....................................... 30 Helderbergian fauna helderbergium, Pseudoblothrophyllum ....... 44

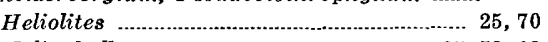
Heliophyllum ‥___........................ 35, 53, 63 venatum ............ 41 Hemicosmophyllum …_- _ $\quad 68,69,70$ (Hemicosmophyllum), Mesophyllum ........ 68 Heterophrentis ............................... 30, 41, 42, 43 nevadensis hexagona, Hexagonaria ………-……….... 60,61 Hexagonaria ……....................... 21, 25, 30,32, $34,37,38,56,58,60,63$

flexum ……………............................... 62

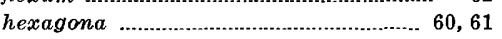
(Hexagonaria) ...................................... 61

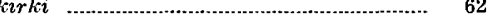
(Pinyonastraea) ………………….... 32, 58 kirki ……......................... 21, 34, 62 (Hexagonaria), Hexagonaria .................... 61 hexagonum, Cyathophyllum ......................... 60 Hidden Valley ................................................ 33 Hidden Valley Dolomite ......................-........... 32, 39 unit $3 \mathrm{~b}$

Hill, Dorothy, eited ........ 33, 34, 38, 67, 68, 69, 71
History of investigation ...............................

Homeomorphic genera ……......................... 34, 30

Hot Creek Canyon ……....................... 32

Hot Creek Range ....................................... 6, 32, 52

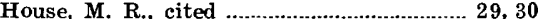

Howellella cycloptera …............................. 19, 29

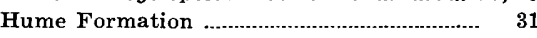

I, J

Independence Shale, Iowa insignis, Hallia

1

42

Breviphrentis ………... 30, 42, 43, 44, 46, 56

Siphonophrentis (Breviphrentis) ...... 21, 30 $32,33,38,42,45,54,56$

Inyo Mountains ……................................... 33

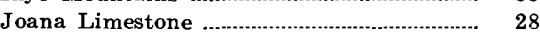

Keriopinyllum

ketophylloides, Kobeha

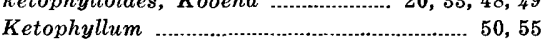
elegantulum ............................................. 50

Kirk, Edwin, cited

kirki, Arcophyllum

$$
\text { Hexagonaria }
$$

(Pinyonastrea)

esophylloides

(Arcophuthm) $21,30,34,69$

Mesophyllum (Arcophyllum) .. 21, 30, 34, 69

Prismatophyllum ......................... 61, 62

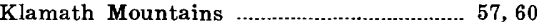

Kobeha _................. 8, 13, 17, 20, 23, 24, 29, $31,32,33,35,36,38,47,49,50,52,53$ fauna ………................................. 8,20 ketophylloides ………-........... 20,33,48,49 walcotti ........ 19, 20, 23, 29, 31, 33, 48, 49, 52

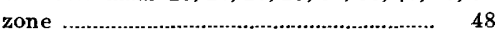
Kobeha Valley project ………………….... 5 kobehana, Acrospirifer .. 13, 20, 24, 32, 33, 52, 66 kobehensis, Breviphrentis .......................... 29 Siphomophrentis (Breviphrentis) ....... 20, $30,33,42,43,66$

Kodonophyllidae …................................... 28, 33, 44

Kodonophyllinae ……………………............... 33, 45

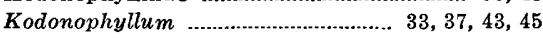
milne-edwardsi

sp. a …......................... 33 sp. $\mathbf{f}$

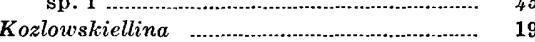

Kwangsi Province, China ......................... 56, 65

Kyphophyllidae ................................................. 60

Laccophyllidae ............................. 17, 27, 33, 37, 38 Laccophyllum ……........................................ 39 acuminatum …….................................. 39

Lake Manitoba ............................................................ 46

Lake Winnipegosis ........................................... 46

Laketown Dolomite ……………………............ 27

Lander County, Nev ………..................... 58 landerensis, Australophyllum .... 20, 23, 33, 34, 57 Late Devonian coral zones ........................... 21

Late middle Devonian coral zones ............... 21

Leiorhynchus castanea .................................. 13, 16

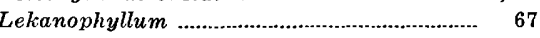

(Lekanophyllum), Mesophyllum ………...... 21

lenticularis, Pleurodictyum .......................... 31

Leonaspis ...................................... 19, 23, 29

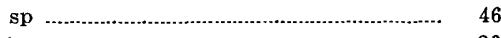

Leptaena .......................................... 20

Leptocoelia ……_.................................. 19, 31

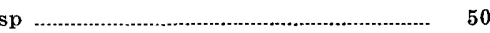
Leptostrophia $\mathrm{sp}$..._.............................. 20

Levenea subcarinata

.. 19, 29, 31 Mesophyllum (Arcophyllum)

Limestone $8,9,15,16,17,19,22,27,32$ argillaceous ….................... 3, 13, 22, 24, 28 calcarenite .............................................. 23

dolomitic ..................... 16, 19, 22, 23, 25, 29 stromatoporoid ...................................... 29

Lithology, Bay State Dolomite Member ...... 16 Beacon Peak Dolomite Member ............. 15

Devils Gate Limestone

Nevada Formation, unit 1 ....................... unit 2 …………………………..... unit 3 …….....................................

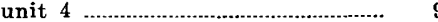
unit 5 ……….............................

Oxyoke Canyon Sandstone Member .... 15

Rabbit Hill Limestone …...................... 17

Sentinel Mountain Dolomite Member.. 15

Woodpecker Limestone Member ......... 16 Locality register …….................................. 71

Lone Mountain …............... 5, 8, 9, 13, 15, 16, 18 $20,22,23,24,25,30,39,43,44,46,47$ $50,51,52,54,55,56,59,60,61,62,63$, $64,65,66,69,70$

reference section .... $6,8,16,17,19,28,30,32$ Lone Mountain Dolomite ............ 8, 15, 19, 27, 28 Lone Mountain Dolomite-Nevada Formation boundary .............. 28

lonense, Bethanyphyllum ................ 21, 33, 54, 55

Cyathophyllum ................................... 53,54

Cystiphylloides ............................... 20,34,66

Mesophyllum .......................................... 66

lonensis, Amplexus ................................... 42, 43

Breviphyllum ….................................... 42 Louisville, Kentucky ..................................... 47

Lower-Middle Devonian boundary ............... 31 loweryi, Gypidula ................................ 20, 21, 52 Lycophyllidae ...................................................... 37,46

\section{$\mathbf{M}$}

MeAllister, J. F., cited

McColley Canyon

32

..... 31, 49

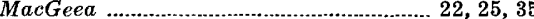
macrostriata, Chonetes .........................20, 21, 32, 52 Maggie Creek ............................................ 20, 31 magnus, A mplexus ..................................... 56 Mahogany Hills ........................... 8, 15, 19, 27, 43 Mapping procedures ................................... Marble Canyon quadrangle, Calif ............... 32 Martinia kirki zone ......................................... 21 undifera ................................................. 55 masoni, Nevadaphyllum ........................... 33, 44 Mazourka Canyon ….................................... 33 meeki, Dalmanites ................. 21, 32, 52 Odontophyllum ............. 20, 29, 30, 33, 46, 47

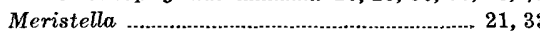
robertsensis ......................................... 20, 33

Merriam, C. W., cited ................................ 22 Mesophylloides kirki ................................ 68, 69, 70 Mesophyllum …......... 21, 25, 30, 33, 34, 65, 67, 68

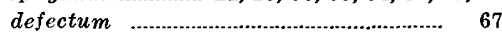

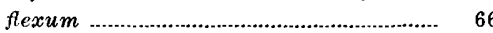

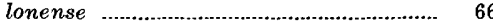
robertsense vesiculosum

(Arcophyllum) 70 kirki …............................ 210,34, 69 limbatum ...................................... 70 (Cystiphylloides) …................................ 65

(Hemicosmophyllum) ............................. 68

(Lekanophyllum) ….............................. 21

(Mesophyllum) .................................. 67,68 sp. b .................................. 21, 34, 68 sp. c .......................................... 34,68

(Mesophyllum), Mesophyllum .................. 67, 68 Methods of investigation

.

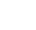

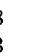

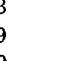

.

.

.

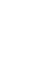

1




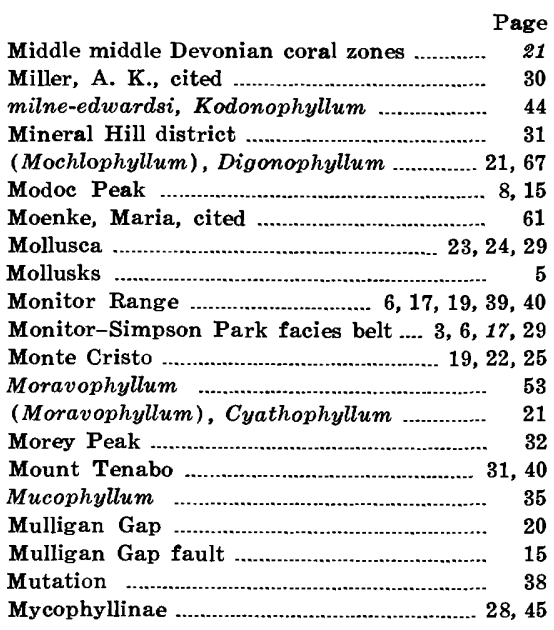

$\mathbf{N}$

Nahanni Formation …......... 31

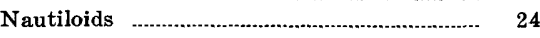
Nevada Formation ...................... 6, 8, 32, 40, 47, $52,54,56,59,63,65,68,71$ barren zone ..................... 3, 8, 13, 15, 21, 25 Beacon Peak Dolomite Member ......... 6, 40 type section

unit $1 \ldots \ldots, 9,11,15,17,19,20,23$ $24,25,28,31,44,46,48,49$, $50,51,52,53,66$

lithology $6,8,13,15,17,19,20,21$ $22,24,27,28,29,30,31,39,42,43$, $44,45,46,52,54,55,59,60,61$, $62,63,64,66,68,69,70,71$

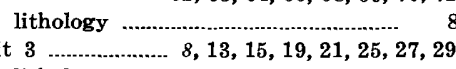
unit $3 \ldots \ldots \ldots \ldots . . . . . . .13,15,19,21,25,27,29$

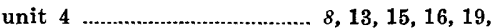
$20,21,22,25,28,29,31,64$ lithology ................................. 9 unit $5 \ldots \ldots \ldots \ldots \ldots . . . . . . .13,13,15,16,19,21,22$ lithology ........................................ 9 nevadana, Atrypa ........................................... 21

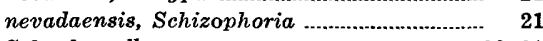
Schuchertella .........................................20,21

Nevadaphyllum ....................... 33, 37, 38, 41, 44

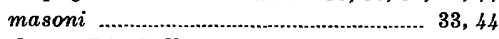
nevadense, Disphyllum .......................34, 59, 60, 66 Grypophyllum .................................... 53

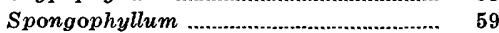
Tabulophyllum ........................................... 53, 54 nevadensis, Agoniatites .................................. 30 Amplexus 42,56 Billingsastraea ... 21, 30,31, 34, 38, 61, 62, 63 Billingsastraea billingsi ........................ 63 Disphyllum ............................................. 21

Heterophrentis ................................ 42, 43 arachne, Billingsastraea .... 34, 38, 62, 63, 64

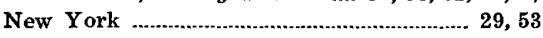

Newark Mountain ........................................... 9

Niagaran reef complex ................................. 22

Nicholsonia .................................................... 39

(Nicholsonia) Alleynia .................................... 39

Nohner Schichten …….......................... 30, 46, 70

North Sand Peak ........................................... 13

Nye County, Nev ............................................ $\quad 32$

o

Odontophyllum …..................... 24, 30, 33, 46, 47 convergens ............................................ 47 meeki …..................... 20, 29, 30,33, 46, 47 patellatum ................................................. 47

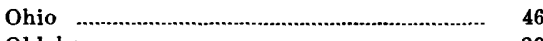

Oklahoma
Page

Old Whalen mine area Oliver, W. A., Jr., cited .................. 23, 24, 25, 38

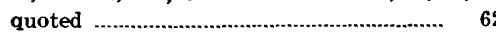
Onondaga Limestone, New York .. 24, 29, 30, 41 Hagersville, Ontario .................................... 65 Orbitoids ......................................................... 34 Oriskany Peak .............................................. 13

Orthoceras .....

Orthoquartzite 15

Orthostrophia strophomenoides ….............. 29

Owens Valley, Calif ...................................... 57

Oxyoke Canyon ........................................... 21

Oxyoke Canyon Sandstone Member.. 8, 13, 15, 32 lithology ............................................ 15

\section{$\mathbf{P}$}

Pachyphyllum ....................... 22, 25, 29, 35, 61

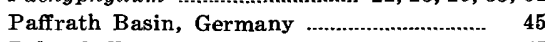
Paleophyllum .............................................. 45

Panamint Mountains .................. 32, 33, 39, 43, 52 Papiliophyllinae ........................... 27, 33, 37, 47 Papiliophyllum 13, 17, 20, 24, 29, 32, 33, 47, 50, 53 elegantulum ....... 20, 24, 32, 33, 46, 47, 50, 66 subsp. d ….............. 20,30,32,33,52,55

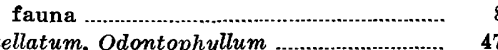
patellatum, Odontophyllum ........................... 47

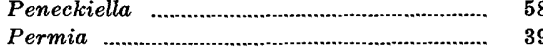

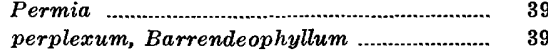
Perry County, Tenn ...................................... 39

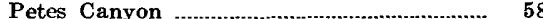
Phacellophyllum ............................... 22, 25, 35, 58

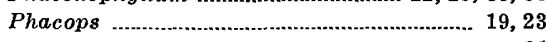
rana ...................................................... 2

Phillipsastraea ..................................... 22, 25, 35

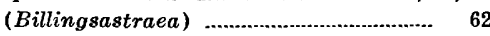

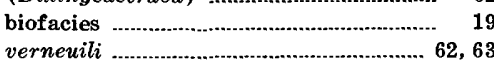

Phillipsastraeidae ....................... 22, 25, 29, 33,

Phillipsburg mine ...................................... 15

Pholidostrophia ............................................ 50

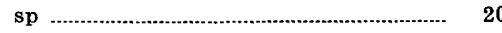

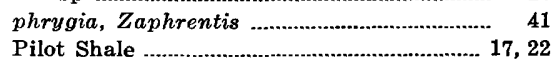

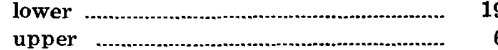

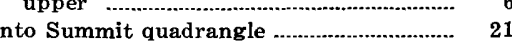

Pinyonastraea .................... 24, 30, 34, 35, 60, 61

(Pinyonastraea), Hexagonaria ............... 32, 58 kirki, Hexagonaria ................. 21, 34, ,38, 62 pinyonensis, Eurekaspirifer ...................... 18, 21

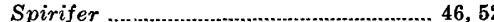
planotabulatum, Sinospongophyllum ....... 55, 56 Plasmophyllum ....................................... 65, 68 Plethorhyncha ............................................ 19 Pleurodictyum ............................... 19, 23, 29, 31 lenticularis ............................................... 31

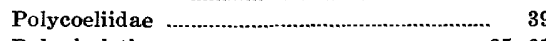
Polyphyletic .................................................. 35, 61 praerhenana, Dendrostella ........................... 46 Favistella (Dendrostella) ....................... 45

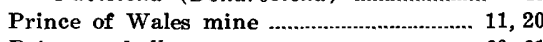
Prismatophyllum ....................................... 60,61

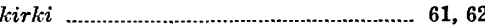
Proetus ........................................................... 19 Protocorallites …............................................ 38 Pseudoblothrophyllum .......................... 43, 44, 45 helderbergium ............................................. 44

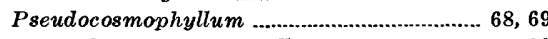
punctulifera, Strophonella ........................... 20 Purpose and scope of investigation ............ pustulosa, Strophonella ............................... 20 Pycnostylidae .......................................... 28, 35 Pyramid Peak .................................................. 32 $\mathbf{Q}, \mathbf{R}$

Quartz grains ....................................... 8, 23, 31
Page

Quartzite ............................................ 32, 55 Queensland, Australia ................................... 57 Rabbit Hill ................................................ 19, 40 Rabbit Hill Limestone ............. 5, 6, 8, 15, 17, 19, $23,28,29,33,39,40,57,58$

lithology ......................................... 17

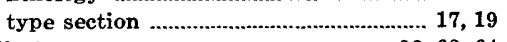
Radiastraea .......................................... 38, 63, 64

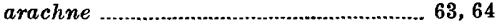

rana, Phacops .............................................. 21 Ranger Mountains .............................32, 43, 52, 71 rectum, Tabulophyllum .............................. 56 Reeds Canyon ................................ 17, 31, 62, 64 Reef Point ......................................... 20 Reefs, patch .............................. 9, 22, 23, 24, 25 Reference section, coral zone C .................. 20 coral zone $\mathrm{D}$............................................. 20

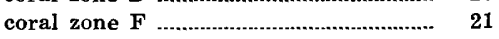
coral zone G …....................................... 21

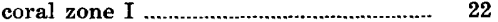
Lone Mountain ....................................... 6, 8 Sulphur Spring Range .................................. 6 Reference sections ............................................ 5

References selected ........................................ 74

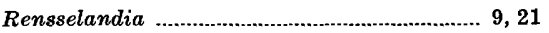
rhenana, Dendrostella ..................................... 46 Favistella (Dendrostella) .................... $\quad \mathbf{4 5}$ rhenanum, Cyathophylloides ......................... 45 Rhine Valley ............................................. 46 Roberts Creek Mountain .............................. 29 Roberts Creek Ranch ................................. $\quad 20$ Roberts Mountains $49,50,52,5$ Roberts Mountains Formation ............ 19, 28, 31 robertsense, Cystiphylloides .................. 21, 34,65 Mesophyllum ............................................ 65 robertsensis, Meristella ............................. 20, 33 robustum, Bethanyphyllum ......................... 53, 54 Cyathophyllum ..................................... 53 romanensis, Dendrostella ..................... 21, 33, 45 Romano Ranch ................... 46 Różkowska, Maria, cited ............................ 24, 38 Rugosa ..................... 1, 8, 18, 19, 20, 22, 25, 33 calice features ......................................... 35

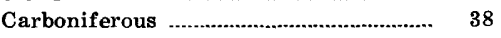
classification ......................................... $\$ 8,35$ Coeymans Limestone ............................. 23 colonial .... 20, 21, 23, 24, 25, 31, 35, 36, 37, 38 Cordilleran ...................................... 3,4 descriptive terms ...................................... 38 digonophyllid ............................................... 69 dissepimented ............................................. 36

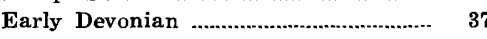
Early Silurian ......................................... $\quad 37$ eastern North America .......................... 3 Eureka mining district .......................... evolution .................................................... 25

Devonian ......................................... 28

Late Silurian ..................................... 28

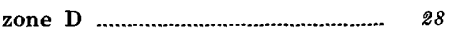

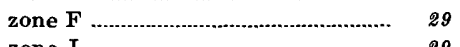

zone I .......................................... 29

exterior corallum features .................... 34, 37 fine structure ........................................ 34,35 Great Basin ................................ 3, 4, 34 growth stages ......................................... 87 interior corallum structures …............. $\$ 5$ Nevada Formation .............................. 3 Ordovician ................................................ 37

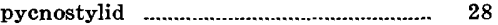
Rabbit Hill Limestone ............................ 3 reproductive features ............................ $\quad s 7$ Rhine Valley ............................................ 4 solitary .................... 21, 24, 25, 35, 36, 37, 38 symmetry .......................................... 37 taxonomy ........................................... 34,38 western North America .......................... Ryan quadrangle, Calif ............................... 32 
Page

$\mathbf{S}$

Sandstone, quartzitic

siliceous

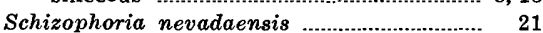

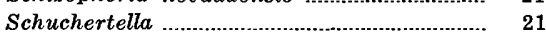

nevadaensis $\quad 20,21$

Section Ridge ............................................... 9

sedgwicki, Spongophyllum ......................... 57

Sellersburg Limestone ................................... 47

Sentinel Mountain .....................................

Sentinel Mountain Dolomite Member …................... 8, $13,15,23$ lithology ............................................... 15

Septa …........................................ 35, 37, 38

Septal stereozone …..................................... 37

Sevy Dolomite .................................................... 27

Silurian-Devonian boundary ....................... 27, 28

siluriensis, Cyathaxonia ................................. 39 Syringaxon ................................ 38, 39,40 Simpson Park Mountains ................ 6, 28, 33, 40 Simpson Park Range ................................... 6, 17

Simpson Peak Range ................................... 19

Sinospongophyllum ............ 32, 33, 38, 41, 44, 55 planotabulatum ....................................55, 56 sp. d …........................................... 52 sp. e .................................................... 33,56 sp. $f$.......................................... 34, 44, 56 spp

Siphonophrentinae .. 17, 27, 29, 30,33, 36, 37, 45 Siphonophrentis ............................... 33, 41, 45 gigantea .................................................... 41 variabilis .................................... $30,42,43,44$ (Breviphrentis) .................................. 32, 41 invaginatus ....................... 21, 30, 32, 33, $38,42,45,54,56$ kobehensis $20,30,33,42,43,66$ (Siphonophrentis) .............................. 41 (Siphonophrentis), Siphonophrentis .......... 41 Sociophyllum ................................... 21, 25,59

Southern Sulphur Spring Range, reference section ................... $6,8,9$ spatiosa, Zaphrentis ................................ 41 Spirifer kobehana zone ................................. 30 pinyonensis ........................................... 46, 52 zone ................ 18, 20, 21, 29, 30, 55, 70 Spirifers ... 32,33

Spongophyllidae …..................... 33, 37, 58, 60 Spongophyllum .......................................... $\quad 57$ cyathophylloides .......................................... 57 expansum ................................................ 59 nevadense .............................................. 59

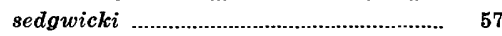
Stathmoelasma .......................................... 53, 54 Stauriidae .............................................33, 34, 45 Stauria ..................................................... 45 astreiformis
Stereoplasmic deposits ................................. $\quad 37$ Stevens County, Wash .................................. 31

Stratigraphy, Central Great Basin Devonian Rocks

Streptelasma corniculum

.................................... 33, 40

Streptelasmidae

Striatopora ........................................... 19, 23

Stringocephalus .................... 9, 15, 16, 21, 46, 70

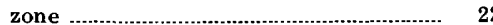

Stromatoporoid-Amphipora biofacies ........ 19

Stromatoporoids ............. 9, 15, 17, 22, 23, 24, 25

strophomenoides, Orthostrophia ................ 29

Strophonella punctulifera pustulosa

cited ......... 4, 22, 33, 51, 57, 66, 69 subcarinata, Levenea ........................... 19, 29, 31 Sulphur Spring Range .................... 6, 8, 9, 11, 13, $15,17,18,19,20,23,24,29,31$ $40,43,45,46,48,49,50,52,54,67,68$

Synaptophyllum Syringaxon .......................... 5, 17, 19, 20, 23, 27, $28,29,31,33,35,36,37,39,58$

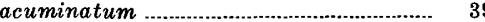
biofacies .................................................. foerstei ...................................... 19, 31, 33, 39 siluriensis ...................................... $38,89,40$ sp .................................................... 31 Systematic paleontology .............................

\section{$\mathbf{T}$}

Tabulae ................................................... 86,37

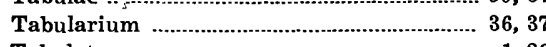

Tabulata ....................................................... 1, 29

Tabulophyllum …................................ 21,55, 56 nevadense ............................................. 53, 54 rectum ....

Taimyrophyllum .............. 21, 25, 29, 32, 58, 61, 6 Taxonomy, Rugosa .......................... $34,36,87,38$ Rugosa, interior corallum ..................... 35 Teicherticeras .......................................... 30, 31

Temnophyllum .................................... 22

Tennessee ............................................................ 29

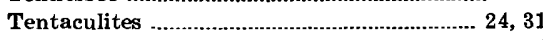

Terrace Butte .............................................. 13, 15

Thrust plates

Toiyabe Range ..................................... 17, 31, 62, 64

Toquima Range ........................ 17, 20, 23, 57, 58

Torquay, England

Tortophyllum

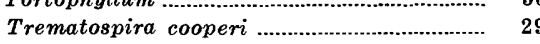
fauna ............................................... 2 Trilobites ............................. 5, 19, 23, 24, 29, 30 Tryplasmatidae ..................................... 34, 35

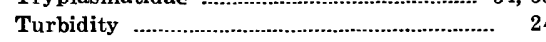

Page

Tuscarora Mountains ....................... 20, 23, 31 Twin Hills ................................................. 11 typus, Arcophyllum ........................................ 68

\section{U, V}

Unconformity

undifera, Martinia

......................... 68,70

Utaratuia ............................................ 21, 25 variabilis, Siphonophrentis ............ 30, 42, 43, 44 Variation

statistical analysis

Vaughn Gulch Limestone ....................... 33, 57 venatum, Heliophyllum ............................... 41 verneuili, Anastrophia .................................. 29

Phillipsastraea ..................................... 62,63 verrilli, Billingsastraea .............................. 31, 64 vesiculosum, Mesophyllum .............................. $\quad 66$

$\mathbf{w}, \mathbf{x}$

walcotti, Kobeha ................................. 19, 20, 23, $29,31,33,48,49,52$

Wales Peak ................................................... 11, 13

Walti Hot Springs area ............................... 40 Wedekind, Rudolf, cited ........ 4, 30, 38, 67, 69, 71 Well, J. W., cited ........................... 35 West Peak .................................................. 8, 20 West Sand Peak ............................................... 13 Whistler Mountain quadrangle ................... 5, 22 White Pine mining district, Nevada ...................... 4, 19, 22, 25 Wisconsin ................................................ 62 Woodpecker Limestone Member ............... 9, 13, $15,16,17,19,21$
lithology

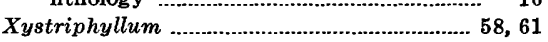

\section{$\mathbf{Y}, \mathbf{Z}$}

Yahoo Canyon .............................................. 22 Yassia

Yoh, S. S., cited Zaphrentidae

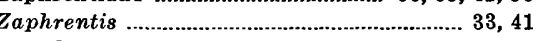
phrygia .................................................... 41 spatiosa

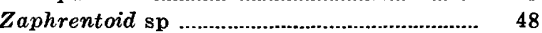

Zoantharia ...

Zonophyllinae ................................ 34, 67, 70

Zonophyllum .......................................... 30, 34, 70 duplicatum .................................. 30, 70,71 haguei ................................... 21, 30, 34, 71 sp. a …................................................ 34, 71 sp. b ..................................................... 71

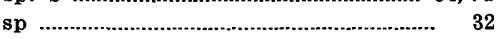




\section{PLATES I-25}

[Contact photographs of the plates in this report are available, at cost, from U.S. Geological Survey Library, Federal Center, Denver, Colorado 80225] 


\section{PLATE 1}

Figures 1-8. Syringaxon foerstei $\mathrm{n}$. sp.

1. Oblique calice view of holotype $\left(\times 1 \frac{1}{2}\right)$, USNM 159243.

2. Lateral view of paratype $(\times 2)$, USNM 159244.

3. Calice view of paratype $(\times 1)$, USNM 159245.

4. Calice view $(\times 2)$.

5. Early ephebic transverse thin section of paratype $(\times 6)$, USNM 159246.

6. Longitudinal thin section of paratype $(\times 6)$, USNM 159247 .

7, 8. Mature transverse thin sections of two individuals $(\times 2, \times 4)$. Early Devonian, Rabbit Hill Limestone; Devonian coral zone A. Locality M187, Rabbit Hill, Copenhagen Canyon, Eureka County, Nev.

9-12. Syringaxon foerstei $\mathrm{n}$. sp.

9, 10. Mature transverse thin section and longitudinal thin section ( $\times 31 / 2)$, USNM 159352.

11, 12. Calice views of two silicified individuals $(\times 2)$.

Early Devonian; Devonian coral zone A. Locality M197, south of Bailey Pass, Sulphur Spring Range, Nev.

13, 14. Syringaxon foerstei $\mathrm{n}$. sp.

Mature transverse thin section and longitudinal thin section of paratype $(\times 4)$, USNM 159248.

Early Devonian, Rabbit Hill Limestone; Devonian coral zone A. Locality M1032, Coal Canyon, Simpson Park Range, Nev.

15, 16. Syringaxon foerstei $\mathrm{n}$. sp.

15. Lateral view of paratype $(\times 2)$, USNM 159249.

16. Lateral view of paratype $(\times 2)$, USNM 159250.

Same horizon and locality as figures 1-8. 



SYRINGAXON 


\section{PLATE 2}

Figures 1-6. Kobeha cf. K. walcotti n. gen., n. sp.

1, 2. Exterior and calice interior $(\times 1)$. Lower Devonian; Devonian coral zone B. Locality M1021, McColley Canyon, Sulphur Springs Range, Nev.

3. Exterior ( $\times 1$ ). Lower Devonian; Devonian coral zone B. Locality M1018, McColley Canyon, Sulphur Spring Range, Nev.

4,5. Longitudinal and transverse thin sections $\left(\times 1 \frac{1}{2}\right)$. Lower Devonian; Devonian coral zone B. Locality M1024, McColley Canyon, Sulphur Spring Range, Nev.

6. Exterior of two attached corallites $(\times 1)$. Lower Devonian; Devonian coral zone B. Locality M1025, McColley Canyon, Sulphur Spring Range, Nev.

7-9. Siphonophrentoid coral.

Lateral and calice views $(\times 1)$ and longitudinal thin section $(\times 3)$. Lower Devonian; Devonian coral zone A (Helderbergian); locality M186, southern Sulphur Spring Range, Nev. 

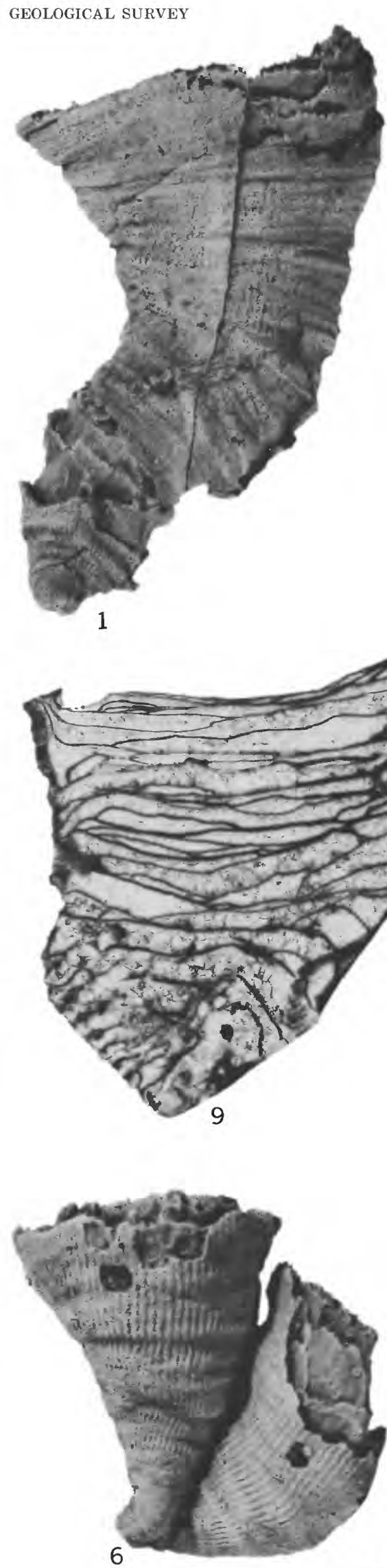
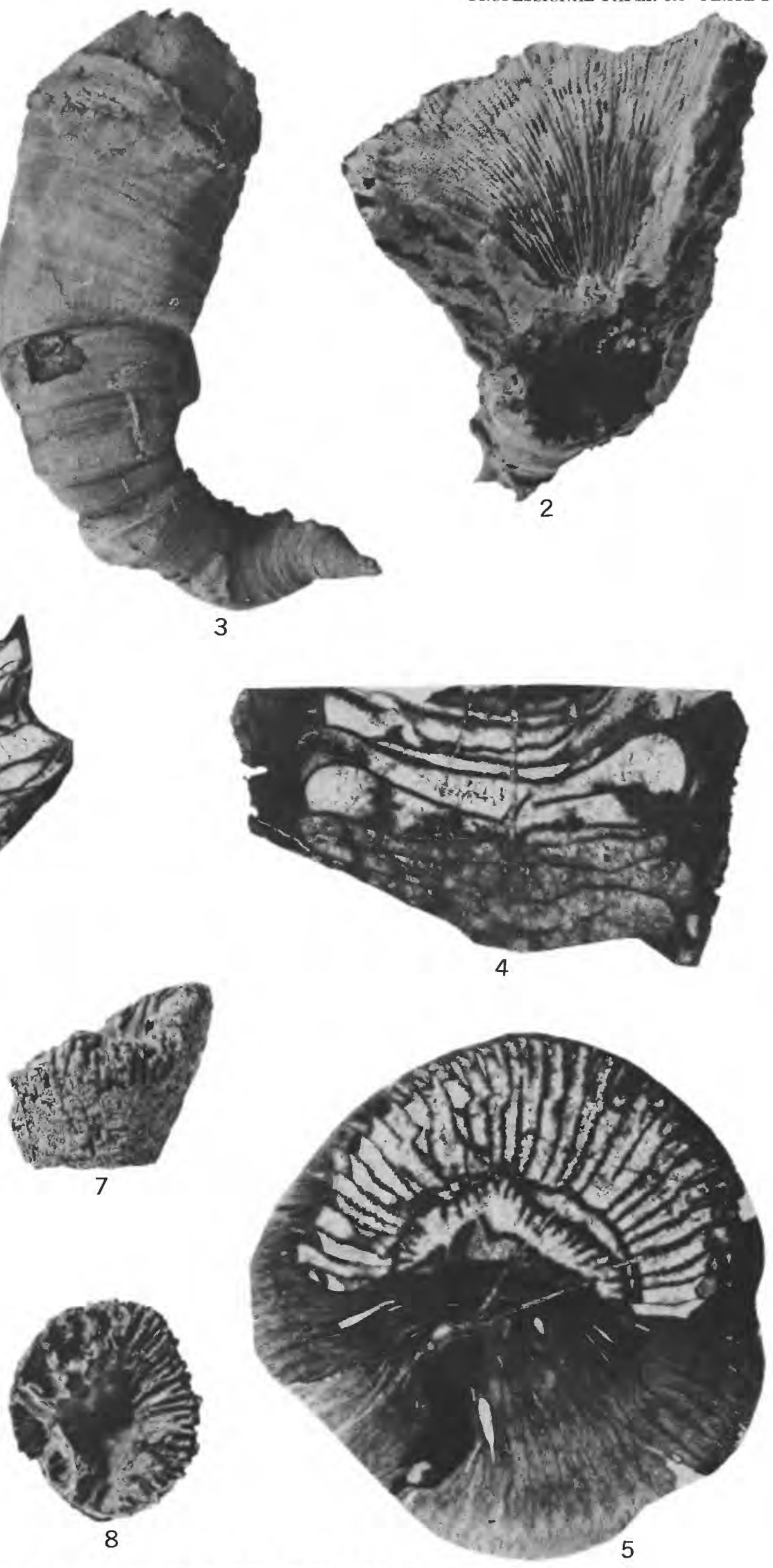

KOBEHA AND SIPHONOPHRENTOID CORAL

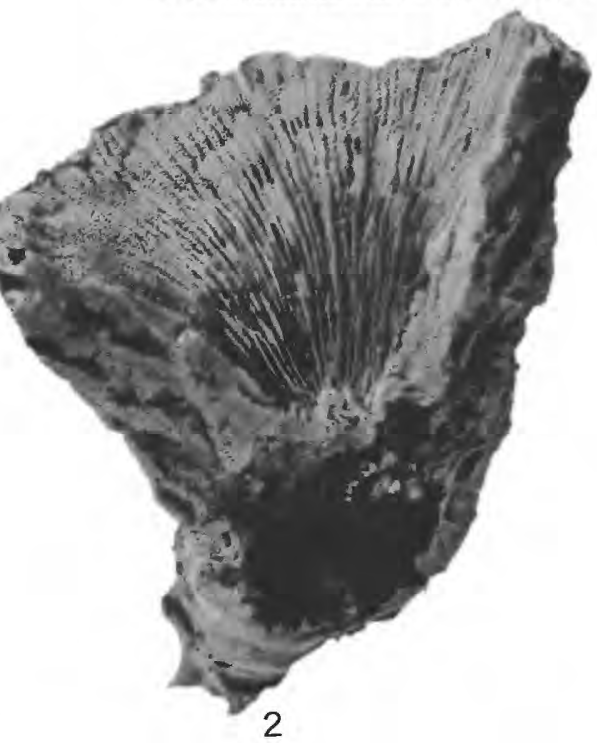

PROFESSIONAL PAPER 805 PLATE 2 


\section{PLATE 3}

Figures 1,2,6. Kobeha walcotti n. gen., n. sp.

1. Calice view of paratype $(\times 1)$, USNM 159251.

2. Lateral view of paratype $(\times 1)$, USNM 159252.

6. Lateral view of holotype $(\times 1)$, USNM 159253.

Lower Devonian, Nevada Formation, unit 1; Devonian coral zone B.

Locality M56, southern Sulphur Spring Range, Nev.

3-5, 8,9. Kobeha ketophylloides $\mathrm{n}$. sp.

3-5. Lateral, calice, and calice interior views of paratype $(\times 1)$, USNM 159254. Lower Devonian, Nevada Formation, unit 1; Devonian coral zone B. Locality M1039, southern Sulphur Spring Range, Nev.

8,9. Oblique calice view $(\times 1)$ and neanic transverse thin section $(\times 2)$ of paratype USNM 159255. Lower Devonian, Nevada Formation, unit 1; Devonian coral zone B. Locality M69, southeast of Prince of Wales mine, southern Sulphur Spring Range, Nev.

7. Kobeha cf. K. walcotti n. gen., n. sp.

Transverse thin section $(\times 2)$ of late neanic stage. Lower Devonian, Nevada Formation, unit 1; Devonian coral zone B. Locality M1040, southern Sulphur Spring Range, Nev. 
GEOLOGICAL SURVEY
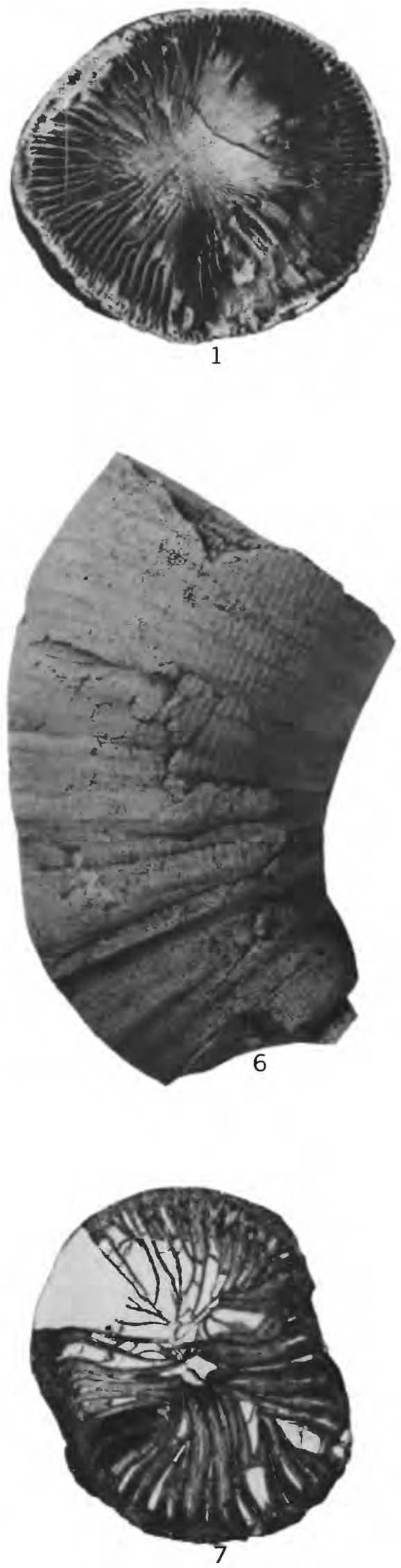

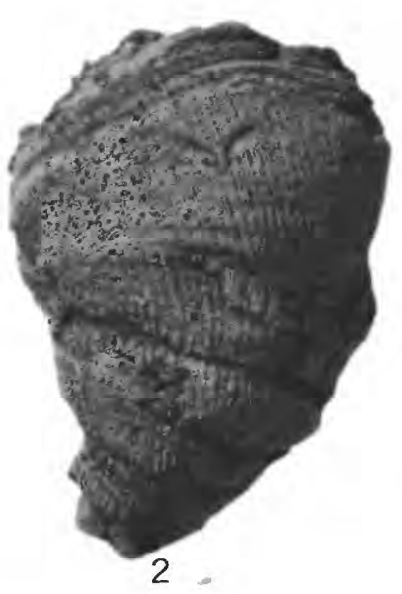

PROFESSIONAL PAPER 805 PLATE 3
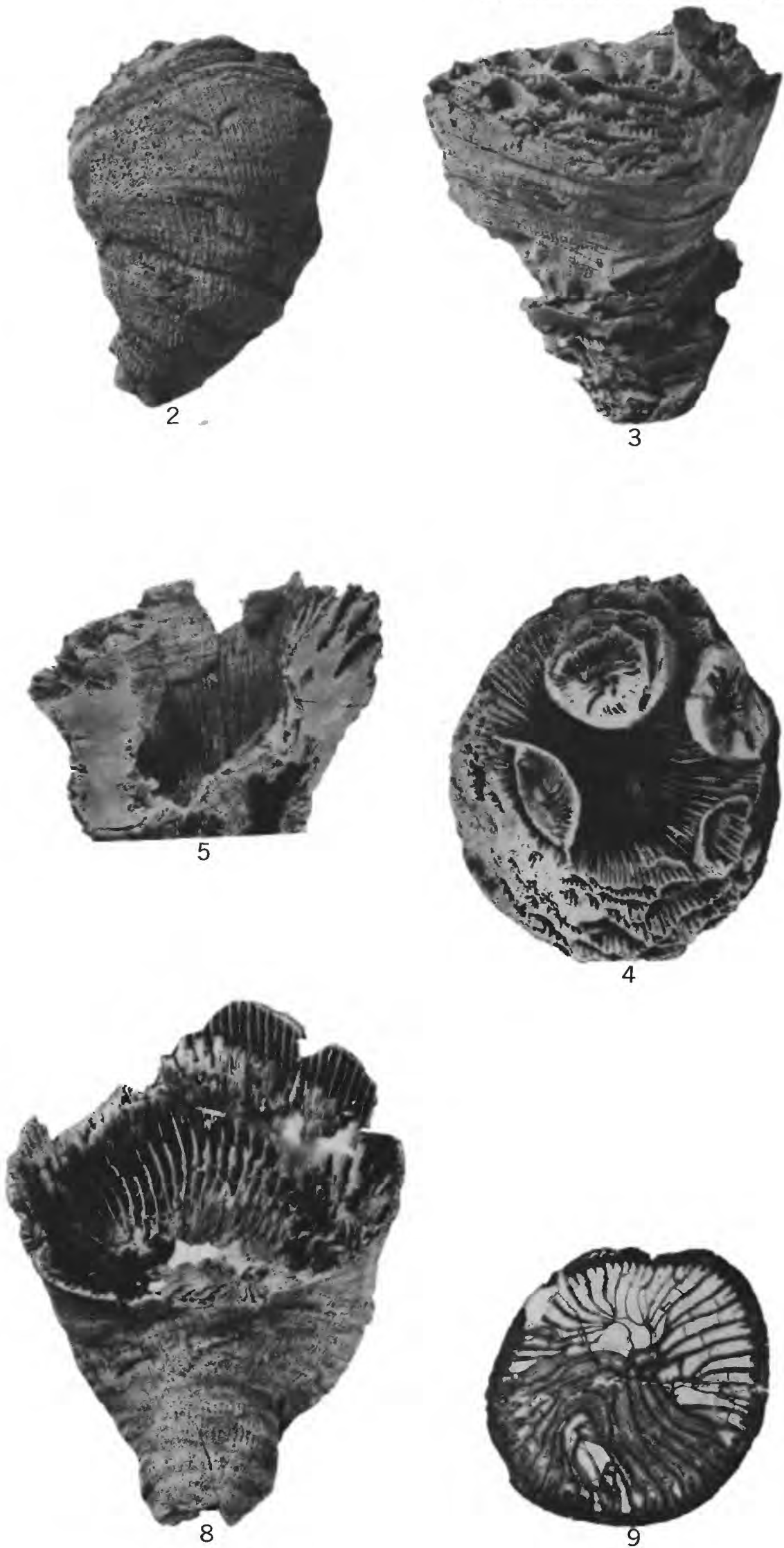

KOBEHA

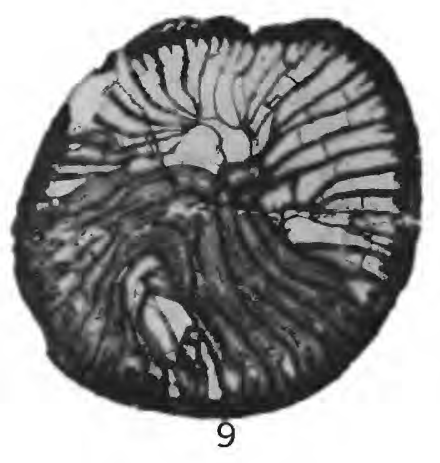




\section{PLATE 4}

Figures 1-4. Kobeha walcotti n. gen., n. sp.

Early ephebic $(\times 2)$, late neanic $(\times 4)$, late ephebic $\left(\times 1 \frac{1}{2}\right)$, and longitudinal thin section $\left(\times 1 \frac{1}{2}\right)$ of paratype USNM 159256. Early Devonian, Nevada Formation, unit 1, Devonian coral zone B. Locality M1041, southeast of Prince of Wales mine, southern Sulphur Spring Range, Nev.

5,6. Kobeha cf. K. walcotti n. gen., n. sp.

Longitudinal thin section $(\times 2)$, neanic transverse thin section $(\times 2)$. Early Devonian, Nevada Formation, unit 1, Devonian coral zone B. Locality M67, southern Sulphur Spring Range, Nev. 

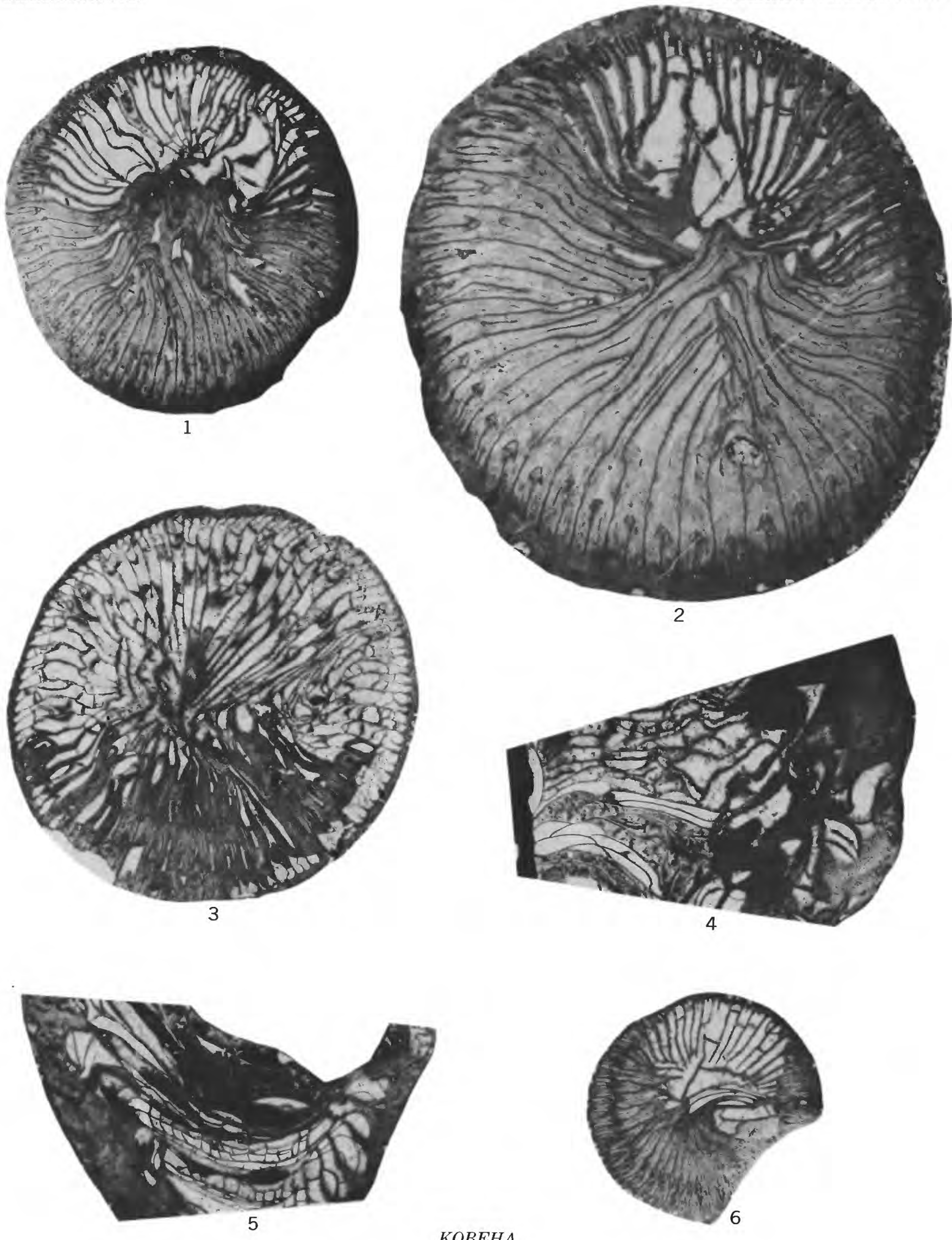

KOBEHA 


\section{PLATE 5}

FiguRes 1-7. Kobeha walcotti n. gen., n. sp.

1,2. Transverse and longitudinal thin sections of paratype $\left(\times 1 \frac{1}{2}\right)$, USNM 159257. Lower Devonian, Nevada Formation, unit 1; Devonian coral zone B. Locality M56, southern Sulphur Spring Range, Nev.

$3-5$. Transverse and longitudinal thin sections $\left(\times 1 \frac{1}{2}\right)$ and transverse thin section of late neanic stage $(x 2)$. Lower Devonian, Nevada Formation, unit 1; Devonian coral zone B. Locality M4, southeast of Prince of Wales mine, southern Sulphur Spring Range, Nev.

6. Longitudinal thin section $(\times 2)$. Lower Devonian, Nevada Formation, unit 1; Devonian coral zone B. Locality M67, northeast of Bailey Pass, southern Sulphur Spring Range, Nev.

7. Longitudinal thin section of holotype $\left(\times 1 \frac{1}{2}\right)$, USNM 159253. Lower Devonian, Nevada Formation, unit 1; Devonian coral zone B. Locality M56, southern Sulphur Spring Range, Nev. 

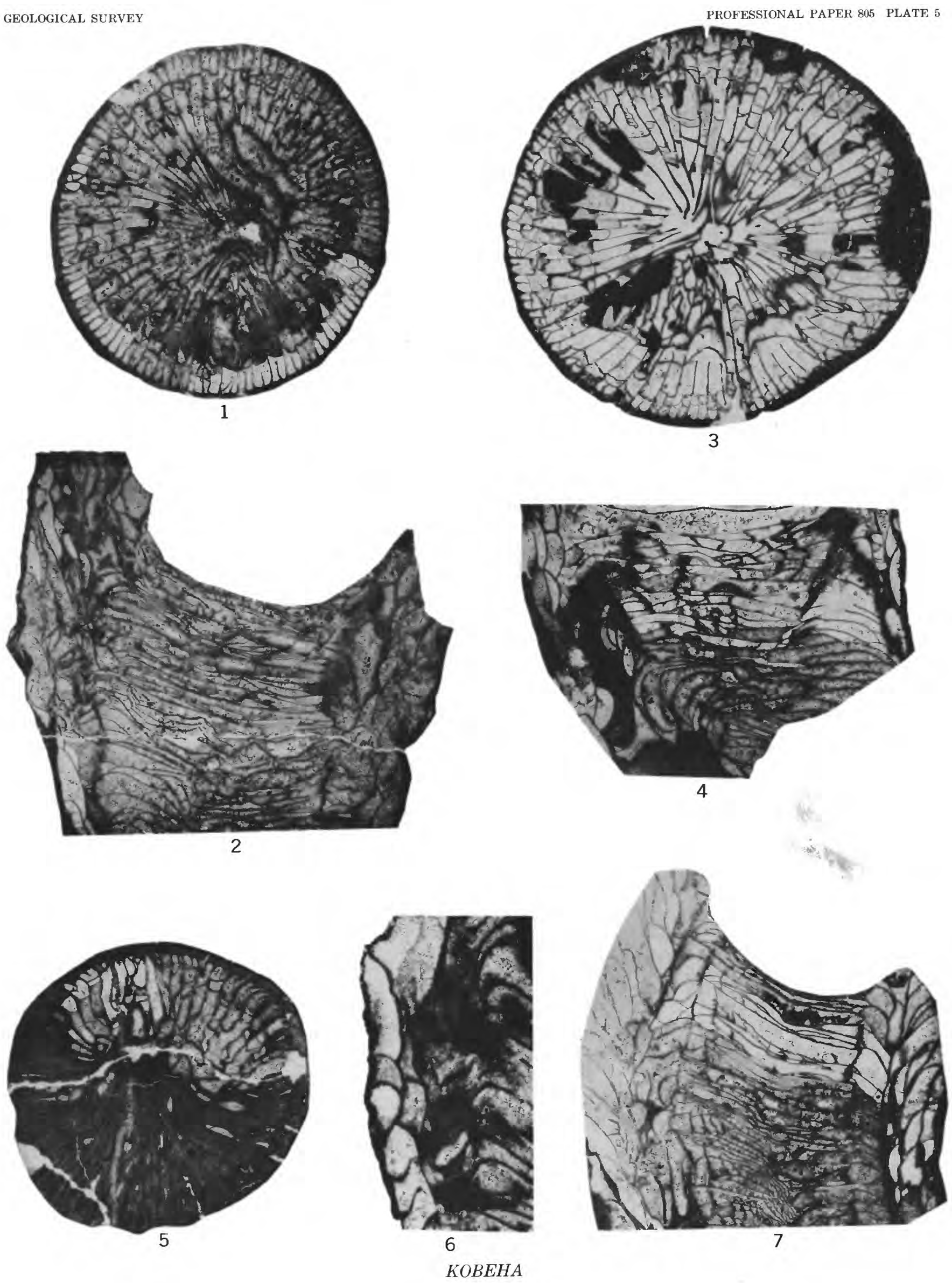


\section{PLATE 6}

FIgURES 1-7. Kobeha ketophylloides n. sp.

1-5. Longitudinal thin section $(\times 2)$, transverse thin section $(\times 1)$, enlargement of previous thin section $(\times 2)$, early ephebic transverse thin section $(\times 2)$, and neanic transverse thin section $(\times 2)$, all of holotype USNM 159258.

6. Neanic transverse thin section $(\times 2)$.

7. Early ephebic transverse thin section of paratype $(\times 2)$, USNM 159259.

Lower Devonian, Nevada Formation, unit 1; Devonian coral zone B. Locality M1042, 1.75 miles north of Roberts Creek Ranch, Roberts Mountains, Nev.

8, 9. Kobeha walcotti $n$. gen., n. sp.

Neanic transverse thin sections $(\times 2),(\times 4)$ of paratype USNM 159260. Lower Devonian, Nevada Formation, unit 1; Devonian coral zone B. Locality M69, southeast of Prince of Wales mine, southern Sulphur Spring Range, Nev.

10. Kobeha walcotti n. gen., n. sp.

Transverse thin section of late nepionic growth stage $(\times 4)$. Lower Devonian, Nevada Formation, unit 1; Devonian coral zone B. Locality M56, southern Sulphur Spring Range, Nev. 
GEOLOGICAL SURVEY

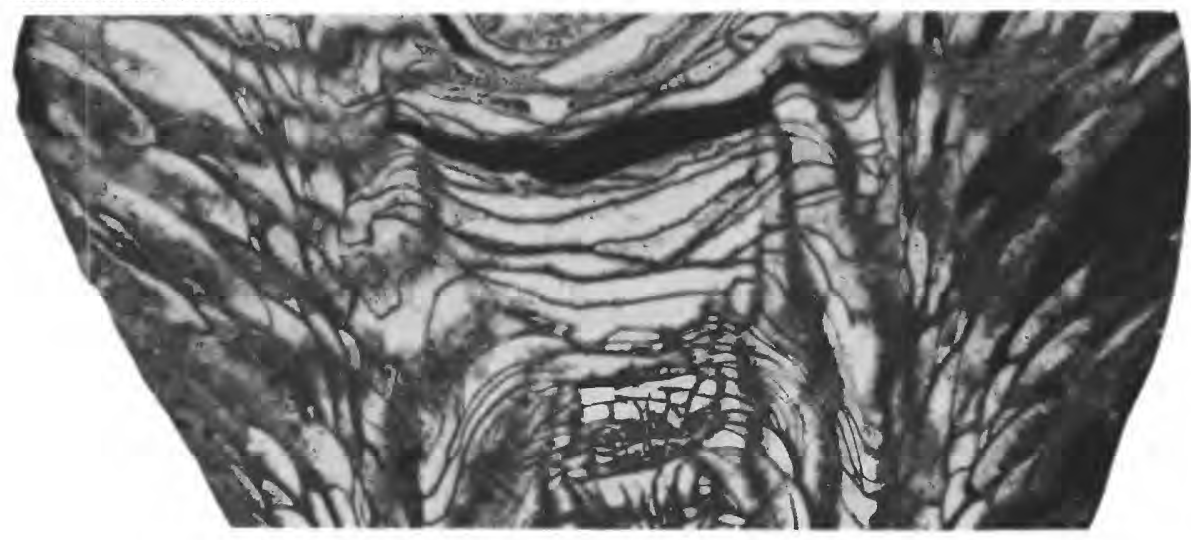

1
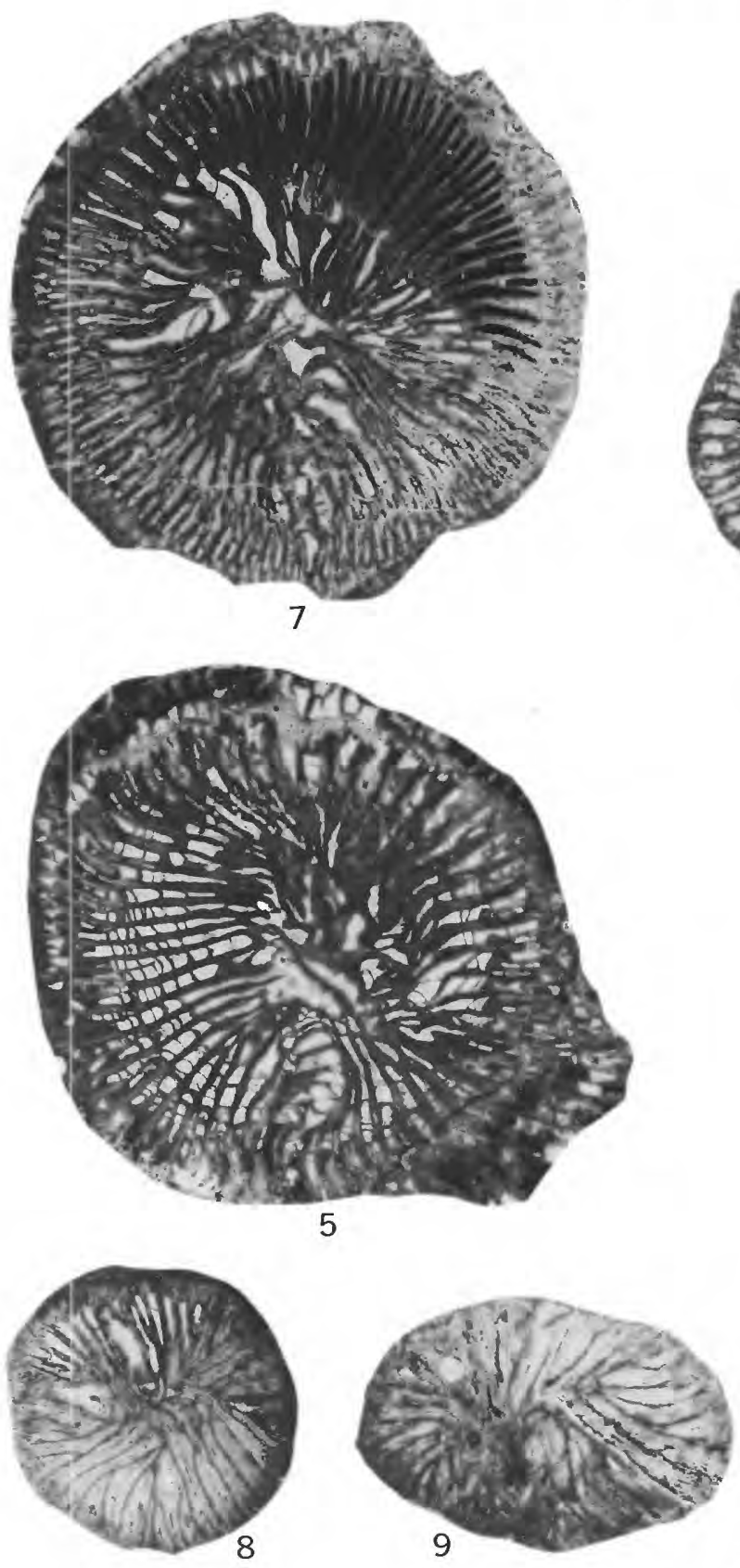

PROFESSIONAL PAPER 805 PLATE 6
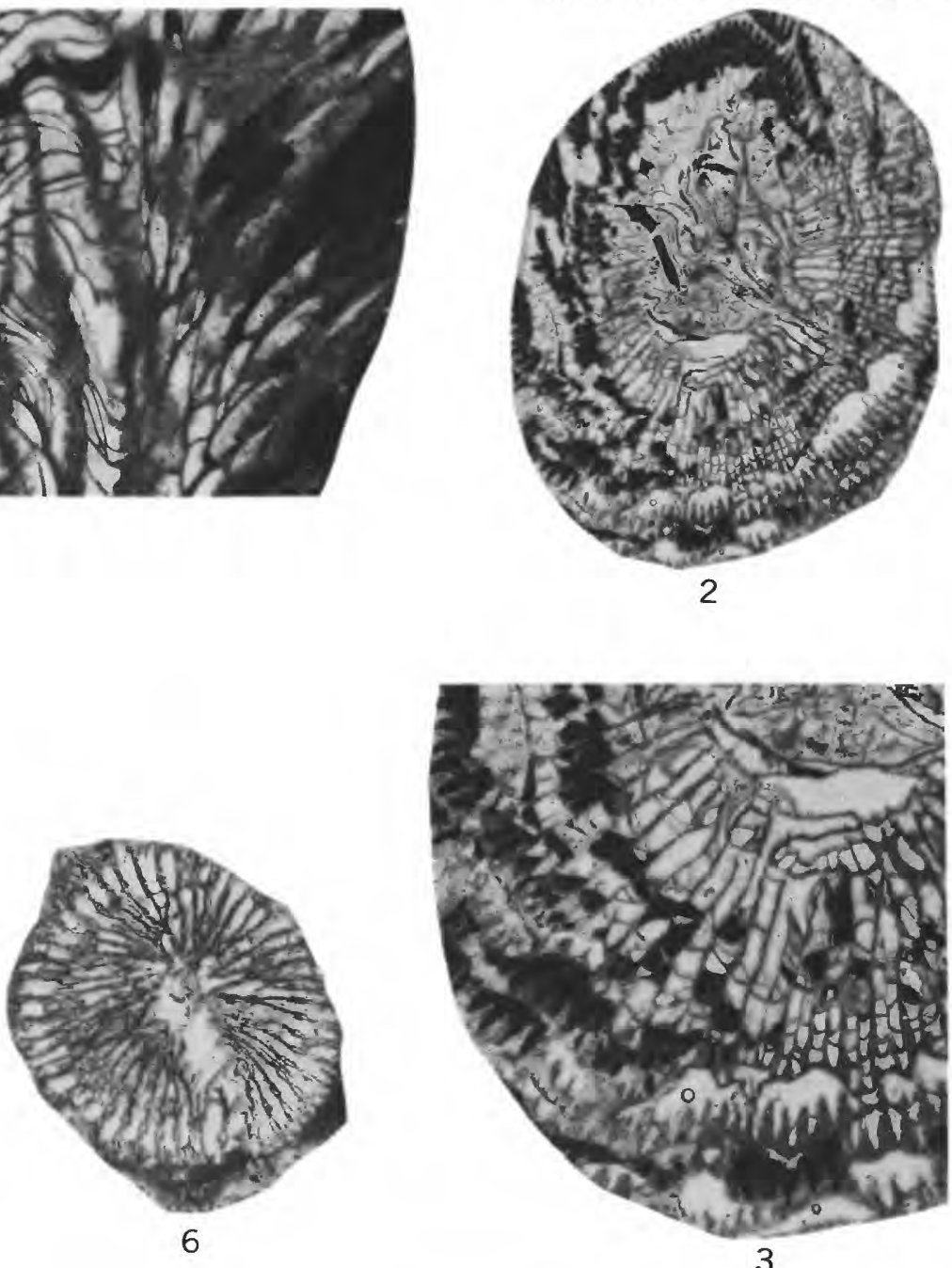

3

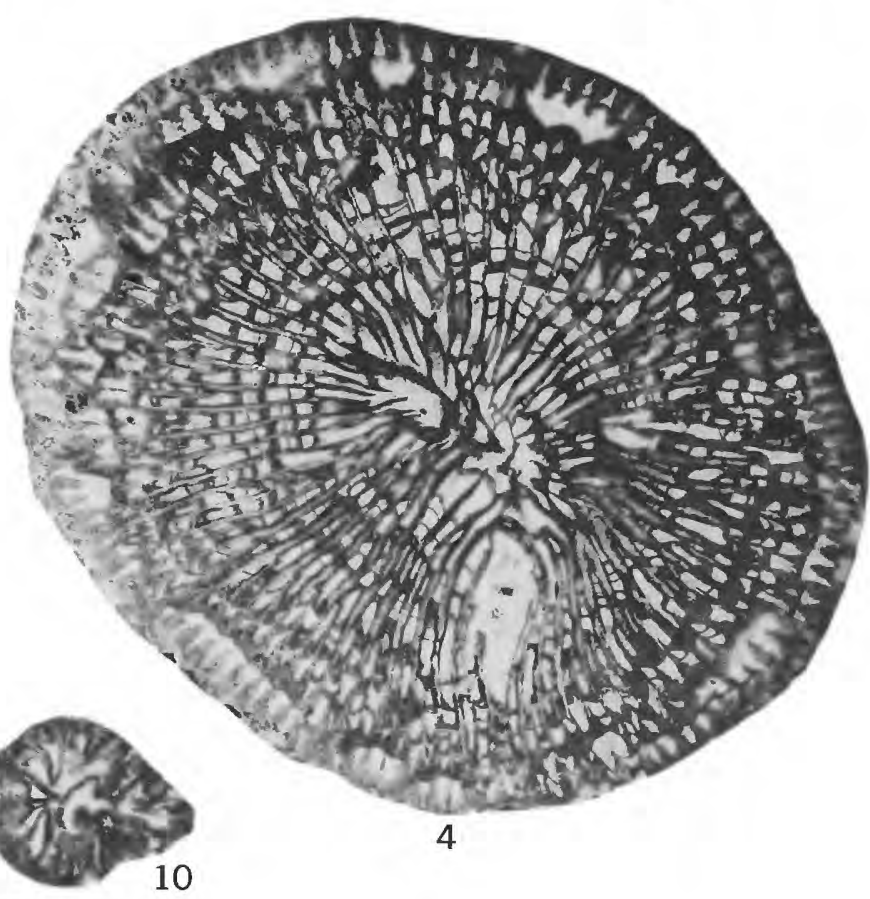

KOBEHA 


\section{PLATE 7}

Figures 1, 2. Papiliophyllum elegantulum subsp.d.

1,2. Transverse and longitudinal thin sections $(\times 11 / 4)$. Late Early Devonian, Nevada Formation, unit 2; Devonian coral zone $\mathrm{D}_{1}$. Locality M1037, south pediment of Lone Mountain, Eureka County, Nev.

3. Papiliophyllum cf. P. elegantulum Stumm.

Lateral exterior $(\times 1)$. From limestone cobble, Locality M1043, Cobble Hill, Cockalorum Wash quadrangle, Fish Creek Range, Nev.

4. Papiliophyllum elegantulum Stumm.

Calice interior $(\times 1)$. Early Devonian, Nevada Formation, unit 1; Devonian coral zone C. Locality M286, Lone Mountain, Eureka County, Nev.

5-7. Papiliophyllum elegantulum Stumm.

Lateral and calice interior views $(\times 1)$ and early ephebic transverse thin section $(x 4)$. Early Devonian, Nevada Formation, unit 1; Devonian coral zone C. Locality M74, Lone Mountain, Eureka County, Nev.

8. Papiliophyllum elegantulum Stumm. Neanic transverse thin section $(\times 4)$. Same locality as figures 5-7.

9. Papiliophyllum elegantulum Stumm. Neanic transverse thin section $(\times 4)$. Same locality as figures 5-7.

10. Papiliophyllum elegantulum Stumm. Late neanic transverse thin section $(\times 2)$. Same locality as figure 4 . 

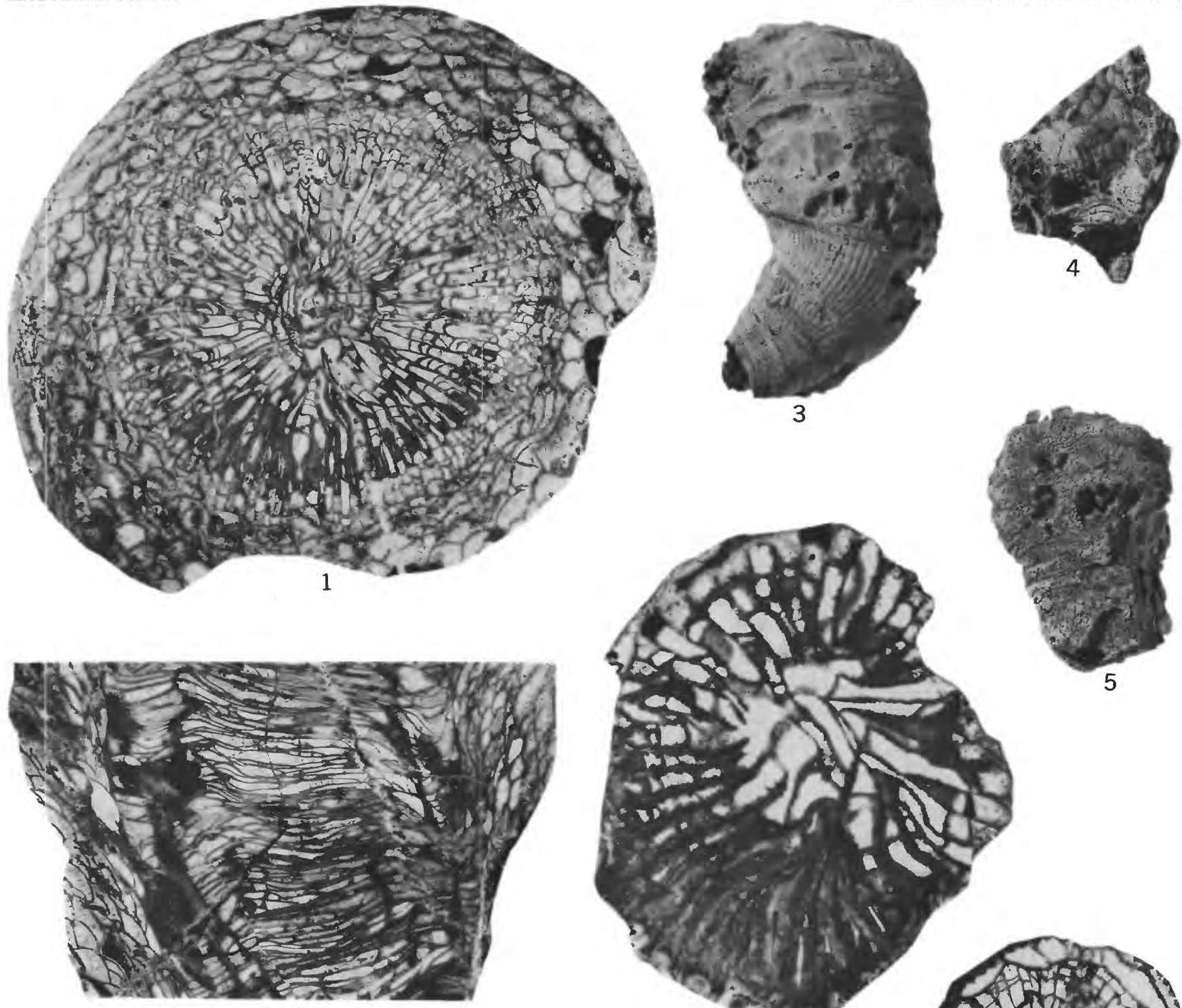

2
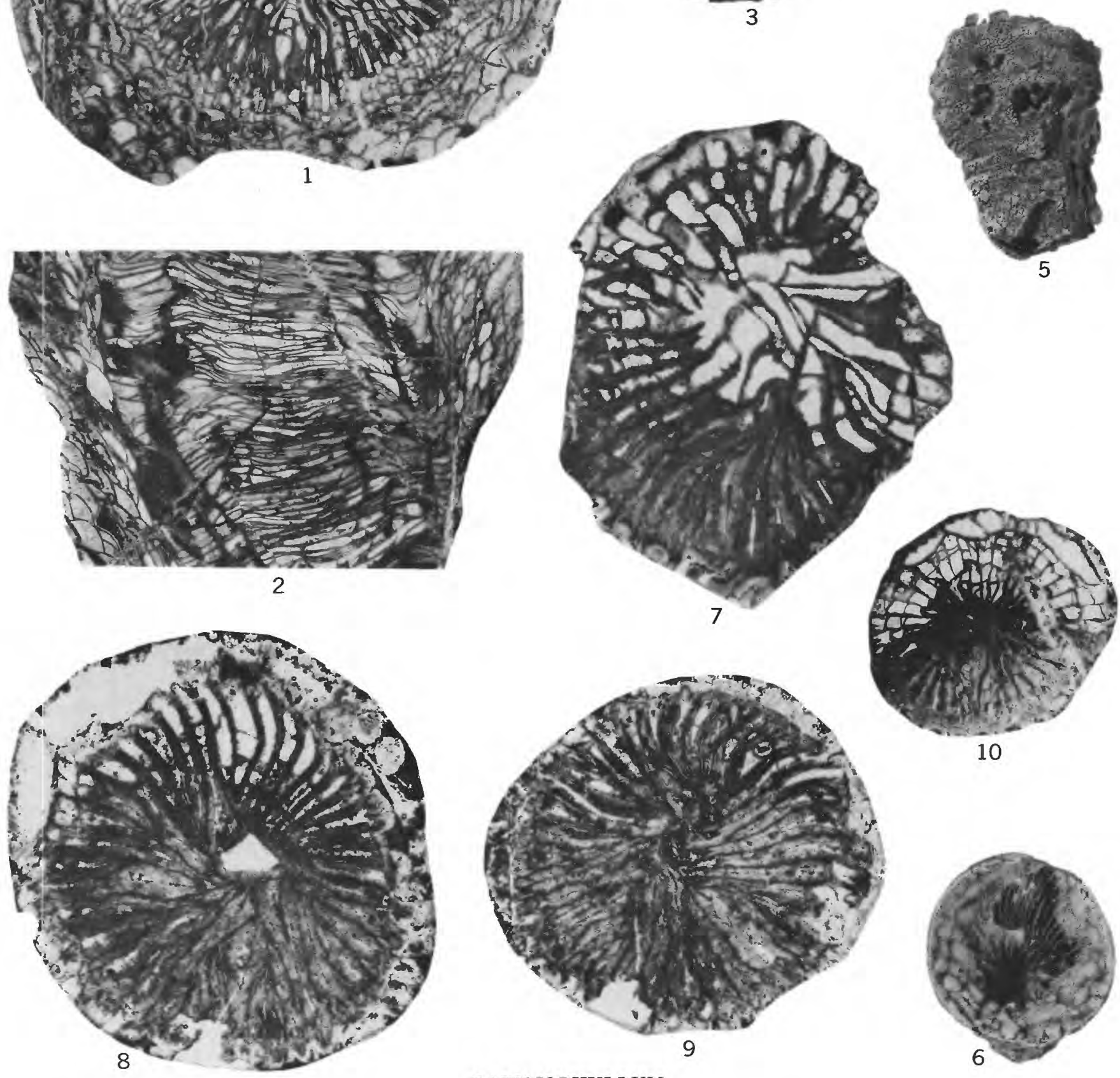

PAPILIOPHYLLUM

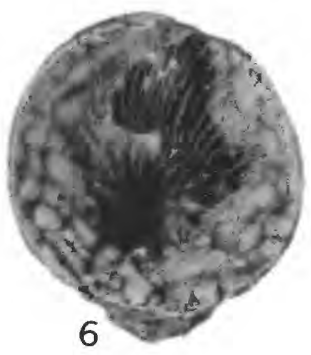




\section{PLATE 8}

Figures 1-4. Papiliophyllum elegantulum Stumm.

Mature transverse thin section $(\times 2)$, early ephebic thin section $(\times 2)$, longitudinal thin section $(\times 2)$, mature transverse section $\left(\times 1 \frac{1}{2}\right)$. Early Devonian, Nevada Formation, unit 1; Devonian coral zone C. Locality M286, northwest side of Lone Mountain, Eureka County, Nev.

5,6. Papiliophyllum elegantulum Stumm.

Longitudinal thin section $(\times 1)$, mature transverse thin section $(\times 1)$. Early Devonian, Nevada Formation, unit 1; Devonian coral zone C. Locality M1044, west side Lone Mountain, Eureka County, Nev.

7. Papiliophyllum elegantulum Stumm.

Longitudinal thin section $\left(\times 1 \frac{1}{2}\right)$. Early Devonian, Nevada Formation, unit 1; Devonian coral zone C. Locality M68, east of Prince of Wales mine, Sulphur Spring Range, Nev.

8. Papiliophyllum elegantulum Stumm.

Early ephebic transverse thin section $(\times 11 / 2)$. Early Devonian, Nevada Formation. Locality M1035a, north end Antelope Range, southern Eureka County, Nev.

9, 10. Eurekaphyllum breviseptatum Stumm.

Longitudinal and transverse thin sections $(\times 1)$ of holotype; copies of original figures (Stumm, 1937, pl. 54, figs. 8a, 8b). Nevada Formation, Lone Mountain, Eureka County, Nev. 
GEOLOGICAL SURVEY
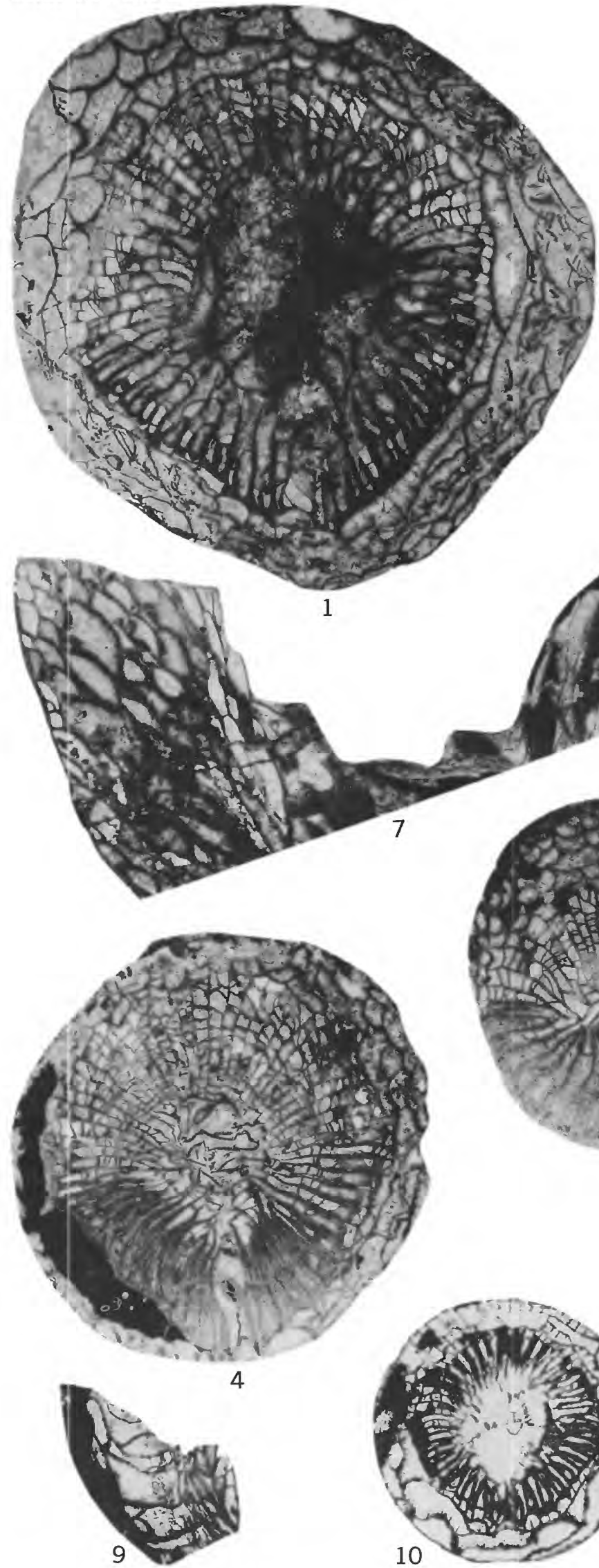
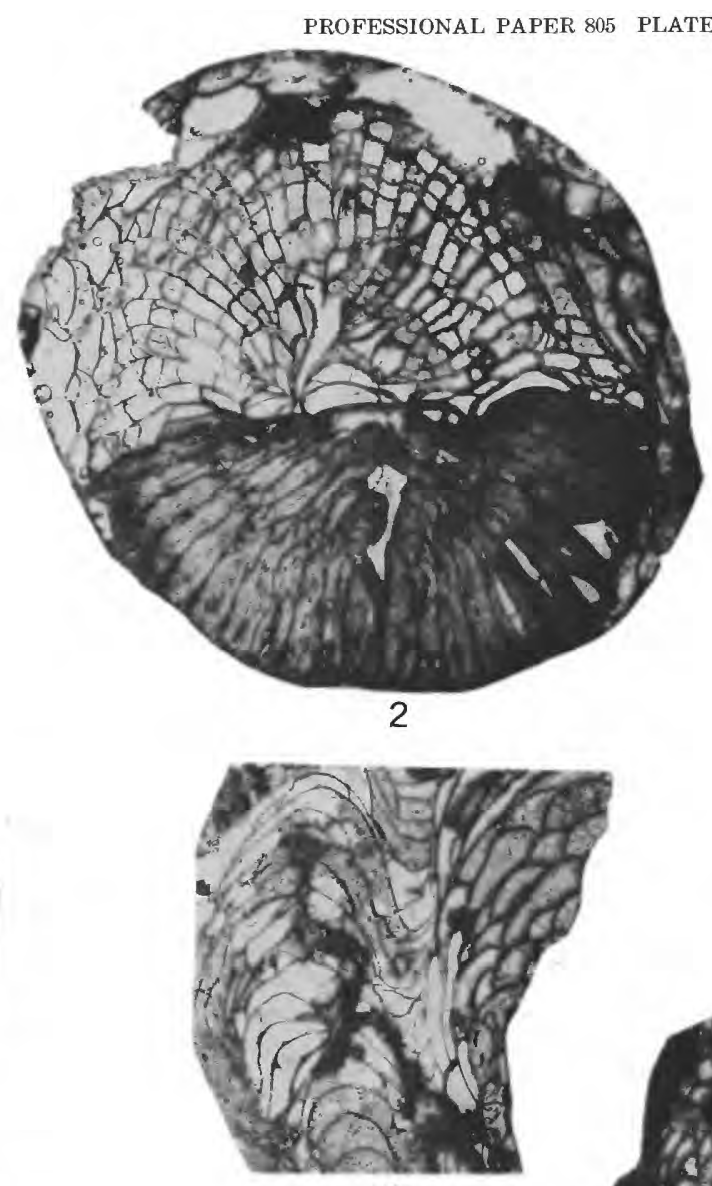

3

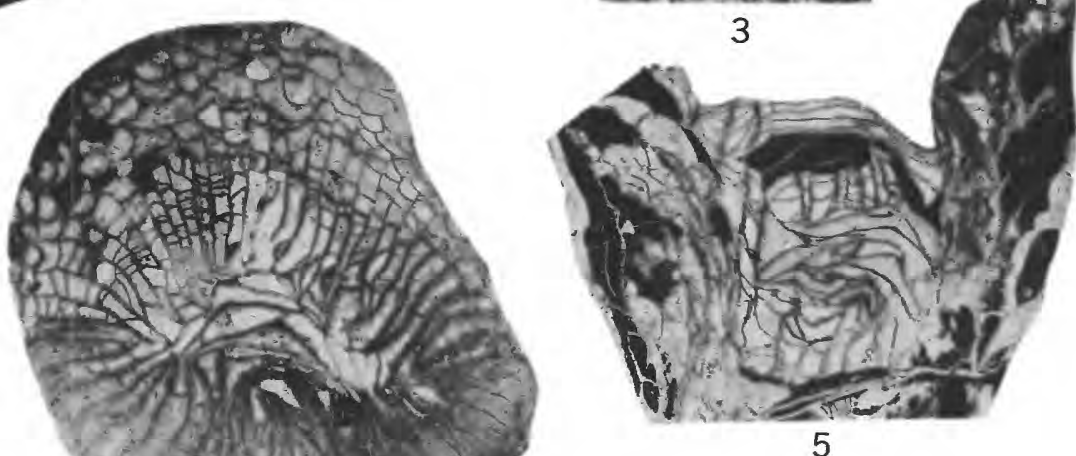

5

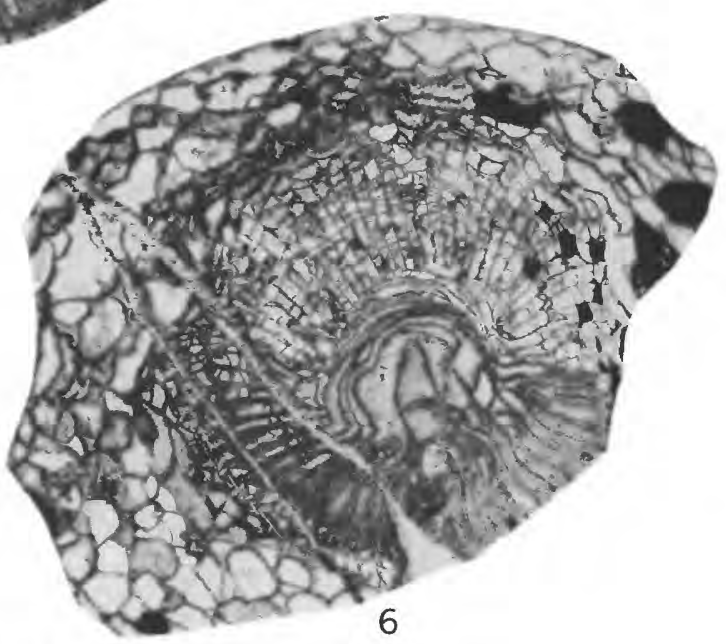

PAPILIOPHYLLUM AND EUREKAPHYLLUM 


\section{PLATE 9}

Figures 1-5. Odontophyllum meeki n. sp.

1-4. Calice view and two lateral views $(\times 11 / 2)$, tilted calice view $(\times 2)$ of holotype USNM 159261.

5. Lateral calice view $(\times 1)$ of paratype USNM 159262.

Early Devonian, Nevada Formation, unit 1; Devonian coral zone C. Locality M74, Lone Mountain, Eureka County, Nev.

6-9. Aulacophyllum sp. c.

6, 7. Calice view $(\times 1)$, early ephebic transverse thin section $\left(\times 3 \frac{1}{2}\right)$. USNM 159263.

8,9. Calice view $(\times 1)$, ephebic transverse thin section $\left(\times 3 \frac{1}{2}\right)$. USNM 159264.

Same horizon and locality as figures 1-5.

10. Aulacophyllum-like rugose coral.

Lateral-interior of weathered specimen $(\times 1)$ showing down-bend of tabulae at fossula. Same horizon and locality as figures 1-5.

11. Aulacophyllum-like rugose coral.

Mature transverse thin section $(\times 2)$. Early Middle Devonian, Nevada Formation, unit 1; Devonian coral zone D. Locality M36, south of Bailey Pass, Sulphur Spring Range, Nev.

12. ?Aulacophyllum sp.

Calice view $(\times 1)$. Same horizon and locality as figures 1-5.

13, 14. ?Odontophyllum sp.

Calice and lateral views $(\times 1)$. Same horizon and locality as figures 1-5. 

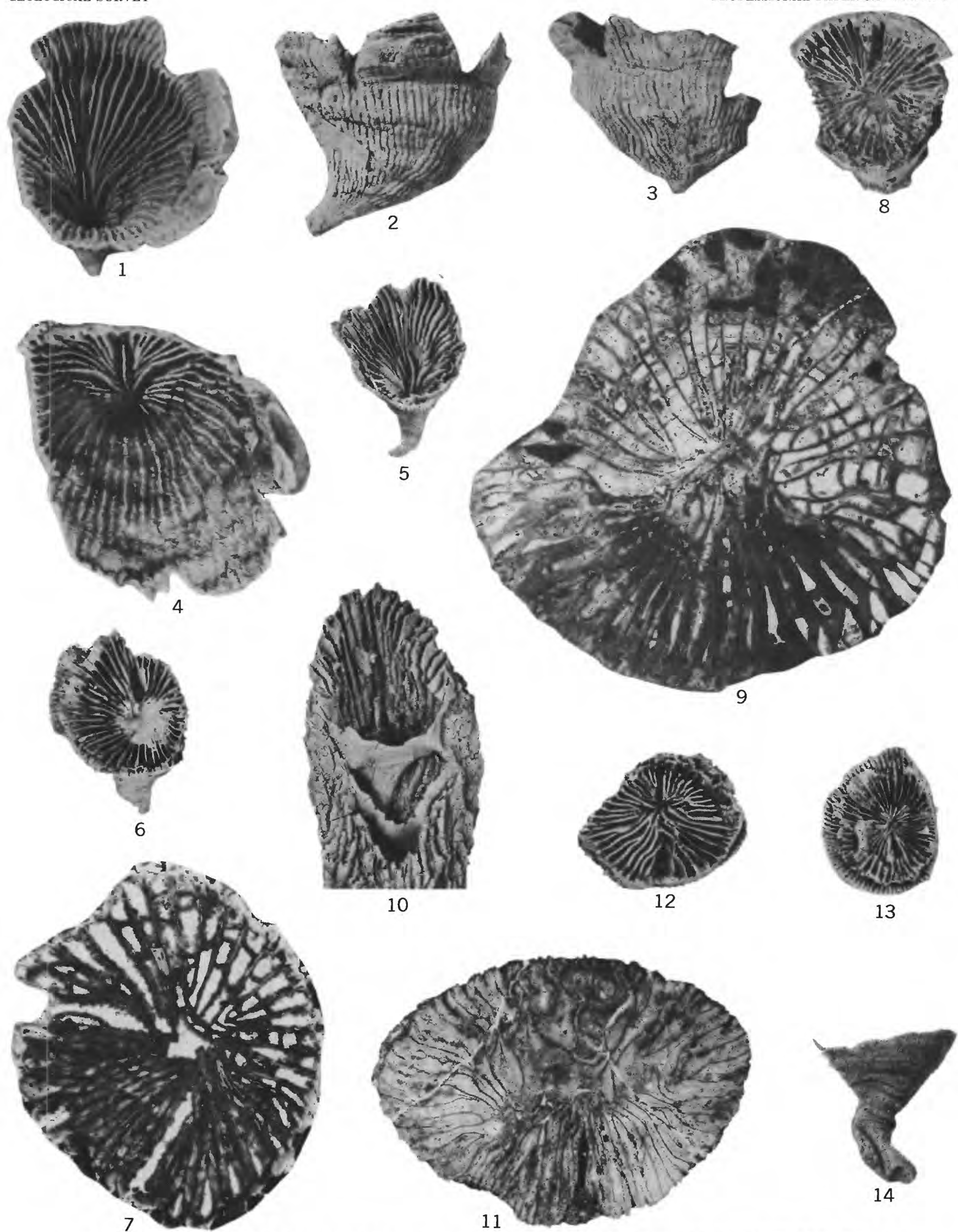

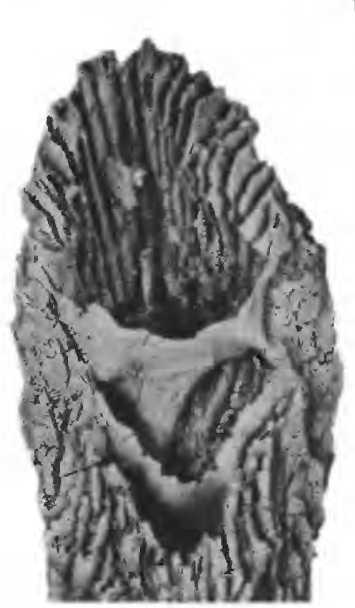

10
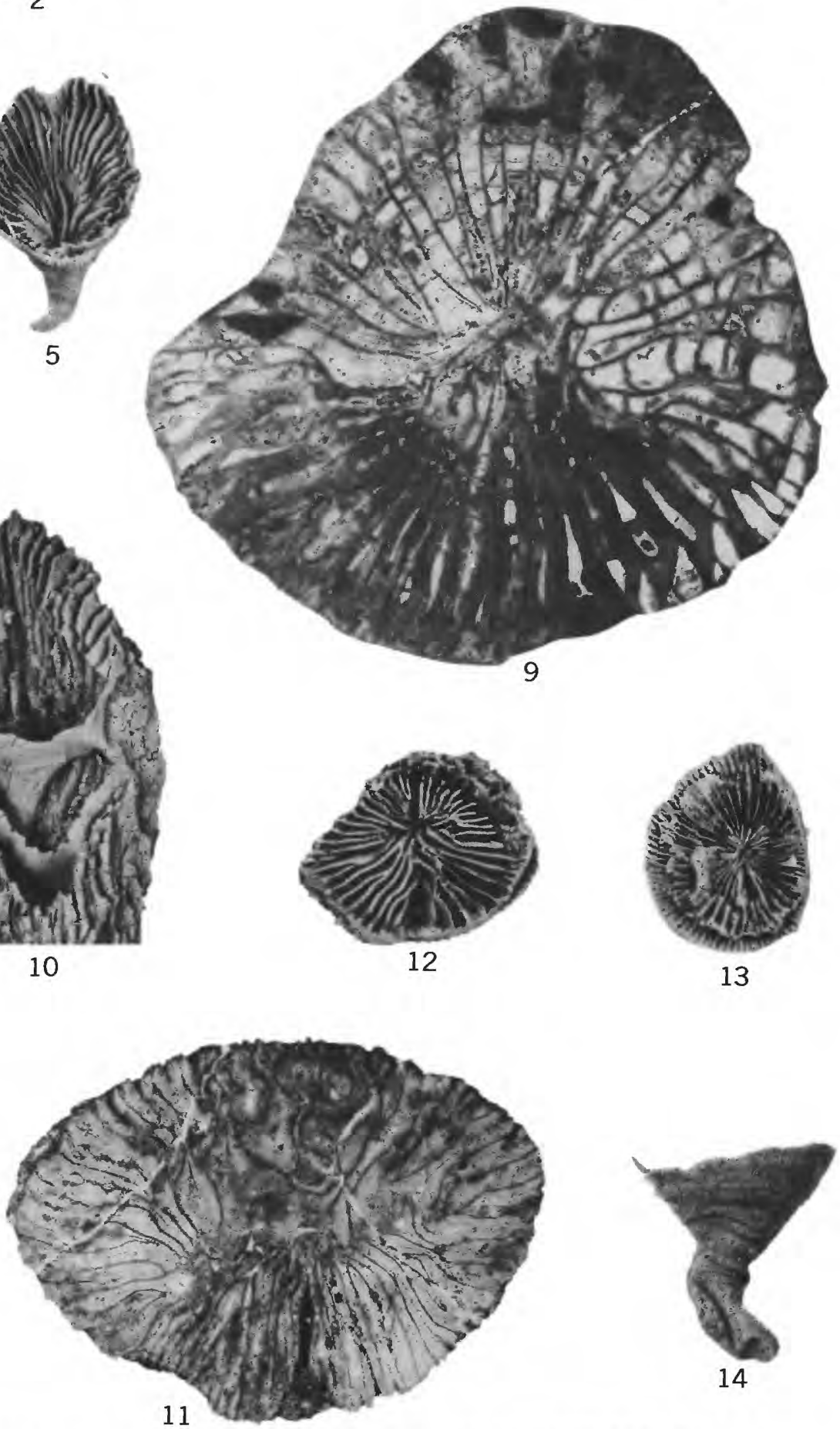

ODONTOPHYLLUM, AULACOPHYLLUM, AND AULACOPHYLLUM-LIKE RUGOSE CORALS 


\section{PLATE 10}

Figures 1-7. Bethanyphyllum antelopensis n. sp.

1,2. Transverse and longitudinal thin sections of holotype $(\times 2)$, USNM 159265.

3. Transverse thin section of paratype $(\times 2)$, USNM 159266.

4. Longitudinal thin section of paratype $(\times 2)$, USNM 159267.

5. Longitudinal thin section of paratype $(\times 2)$, USNM 159268.

6,7. Late neanic thin section $(\times 4)$ and ephebic thin section $(\times 2)$ of paratype USNM 159269.

Early Middle Devonian, Nevada Formation, unit 2; Devonian coral zone $\mathrm{D}_{2}$. Locality M27, Combs Peak, southern Mahogany Hills, Bellevue Peak quadrangle, Eureka County, Nev.

8-10. Bethanyphyllum sp. d.

8, 9. Neanic transverse thin section $(\times 4)$ and longitudinal thin section ( $\times$ 2), USNM 159270. Late Early Devonian, Nevada Formation; Devonian coral zone $D_{1}$. Locality M1037. Pediment slopes, south side of Lone Mountain, Eureka County, Nev.

10. Neanic transverse thin section $(\times 4)$, USNM 159271. Same horizon and locality as figures 8,9 . 

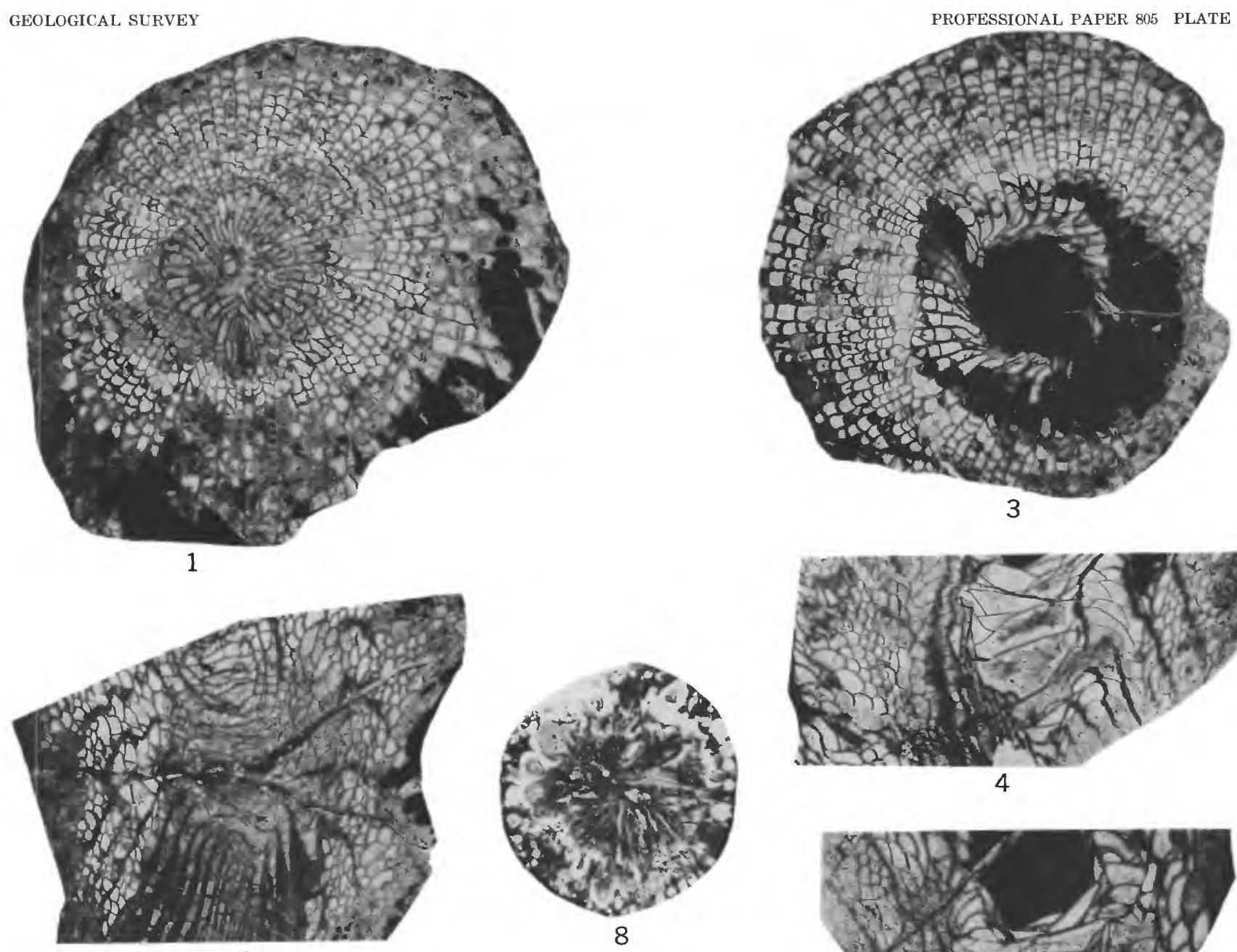

2
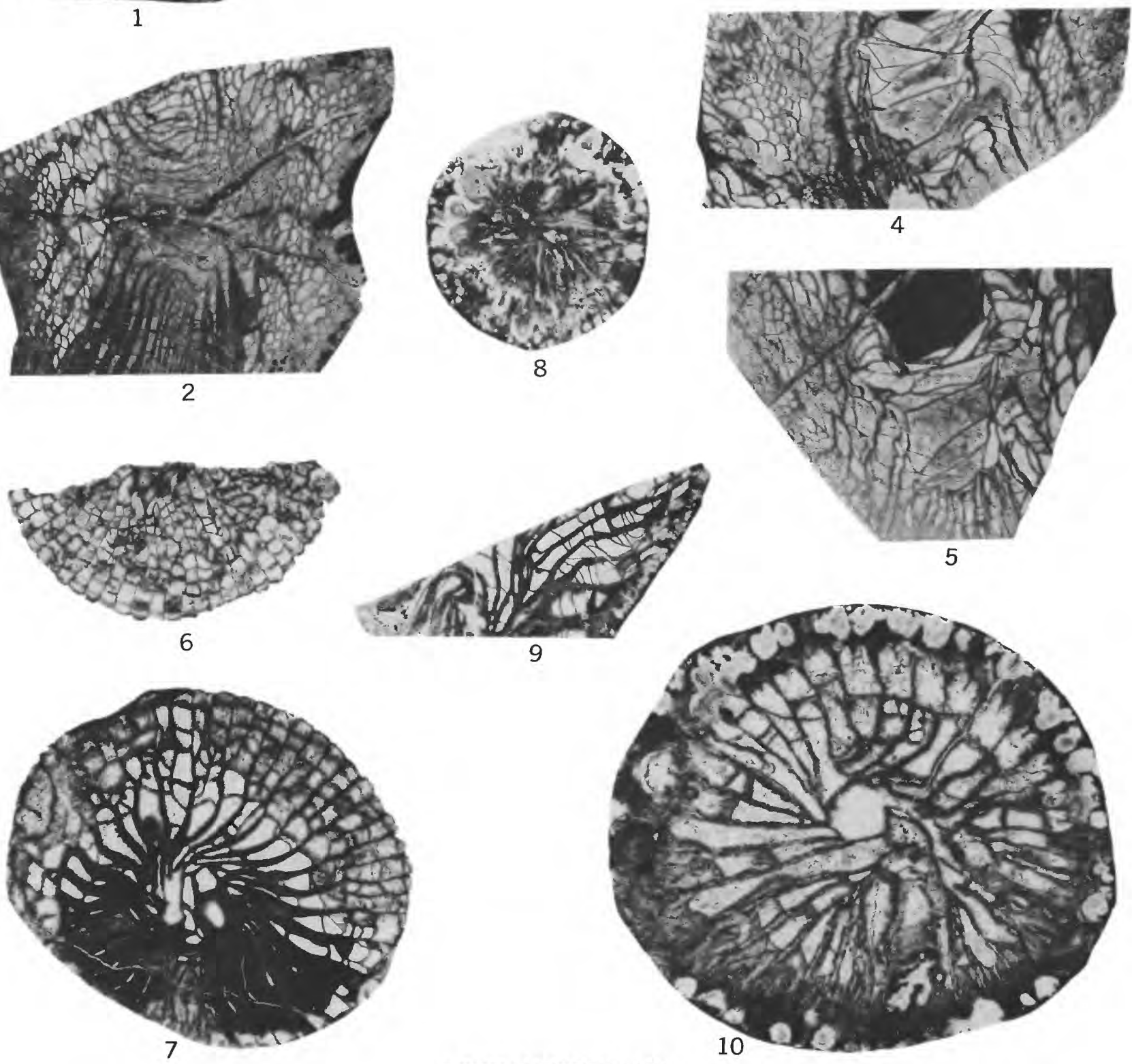

BETHANYPHYLLUM 


\section{PLATE 11}

Figures 1-4. Bethanyphyllum lonense (Stumm).

1,2. Transverse and longitudinal thin sections $(\times 2)$, USNM 159272.

3 , 4. Transverse and longitudinal thin sections $(\times 2)$, USNM 159273.

Early Middle Devonian, Nevada Formation, unit 2; Devonian coral zone $\mathrm{D}_{2}$. Locality M3, Grays Canyon, southern Eureka district, Nevada.

5,6. Bethanyphyllum antelopensis $\mathrm{n}$. sp.

Transverse and longitudinal thin sections of paratype $(\times 4)$, USNM 159274. Early Middle Devonian, Nevada Formation, unit 2; Devonian coral zone $\mathrm{D}_{2}$. Locality M27, Combs Peak, southern Mahogany Hills, Bellevue Peak quadrangle, Nevada.

7-9. Bethanyphyllum cf. B. antelopensis n. sp.

Exterior $(\times 1)$, longitudinal thin section $(\times 2)$, transverse thin section ( $\times$ 2), USNM 159275. Middle Devonian, Nevada Formation, unit 2; Devonian coral zone $\mathrm{D}_{3}$. Locality M1045, northwest side of Lone Mountain, Eureka County, Nev. 

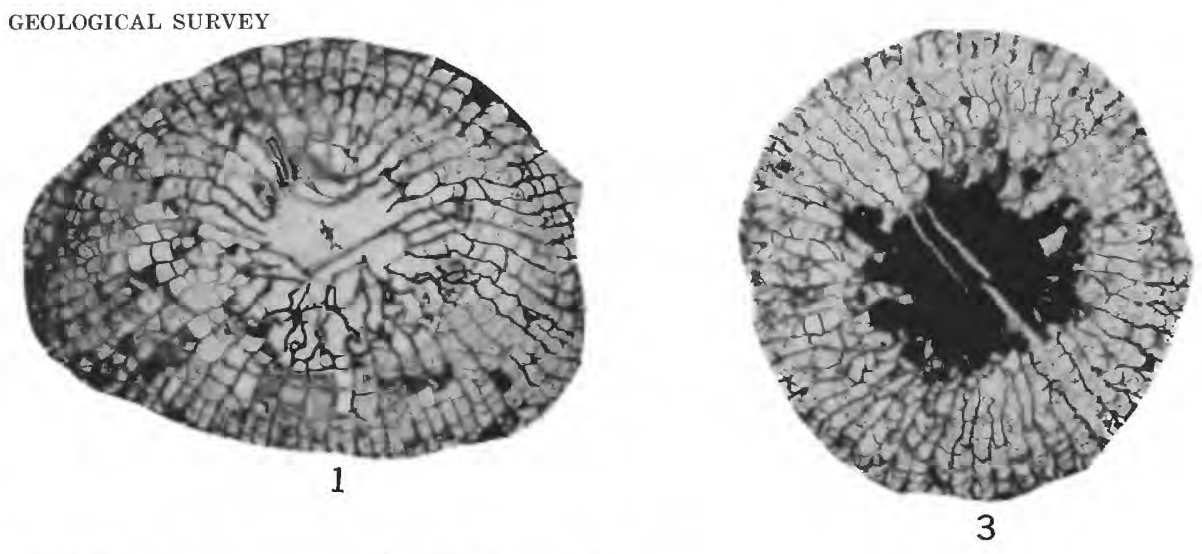

PROFESSIONAL PAPER 805 PLATE 11
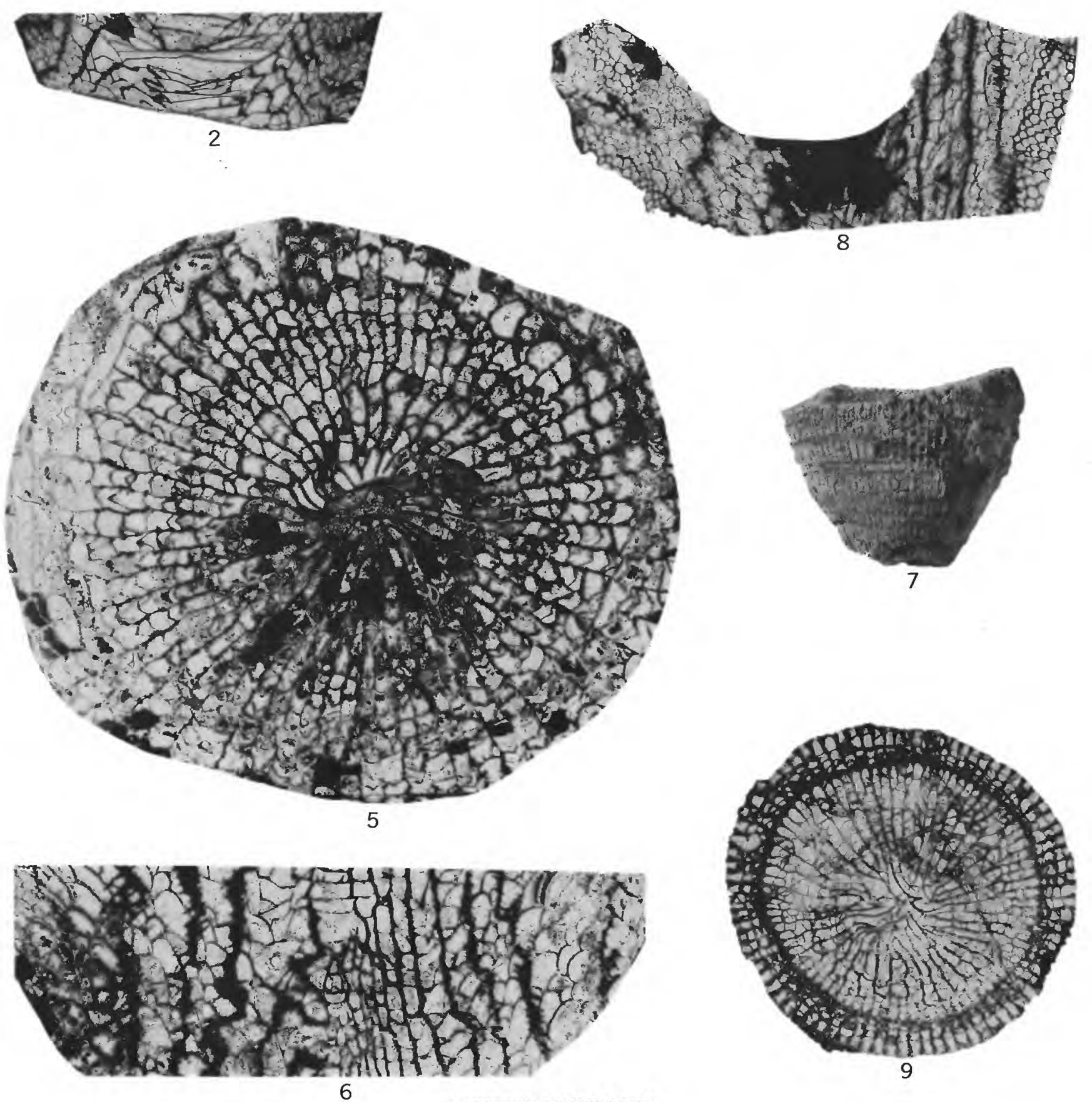

BETHANYPHYLLUM 


\section{PLATE 12}

Frgures 1,2. Bethanyphyllum cf. B. lonense (Stumm).

Transverse and longitudinal thin sections ( $\times 1 \frac{1}{2}$ ), USNM 159276. Early Middle Devonian, Nevada Formation, unit 2. Locality M1046, Lone Mountain, Eureka County, Nev.

3-5. Bethanyphyllum lonense (Stumm).

Two transverse thin sections and a longitudinal thin section $(\times 2)$, USNM 159277. Middle Devonian, Nevada Formation, unit 2; Devonian coral zone $\mathrm{D}_{2}$. Locality M1047, east side Sulphur Spring Range, Nev.

6-8. Bethanphyllum lonense (Stumm).

Longitudinal section, early ephebic thin section and neanic thin section ( $\times$ 2), USNM 159278. Middle Devonian, Nevada Formation, unit 2; Devonian coral zone $\mathrm{D}_{2}$. Locality $\mathrm{M} 1048$, northwest side of Lone Mountain, Eureka County, Nev.

9-10. Bethanyphyllum lonense (Stumm).

Transverse and longitudinal thin sections $(\times 2)$, USNM 159279. Devonian, Nevada Formation, unit 2; Middle Devonian coral zone $\mathbf{D}_{2}$. Locality M3, Grays Canyon, southern Eureka district, Nevada.

11. Bethanyphyllum antelopensis $\mathrm{n}$. sp.

Longitudinal thin section at calice $(\times 2)$. Middle Devonian, Nevada Formation, unit 2; Devonian coral zone $\mathrm{D}_{2}$. Locality M27, Combs Peak, southern Mahogany Hills, Bellevue Peak quadrangle, Nevada. 
GEOLOGICAL SURVEY
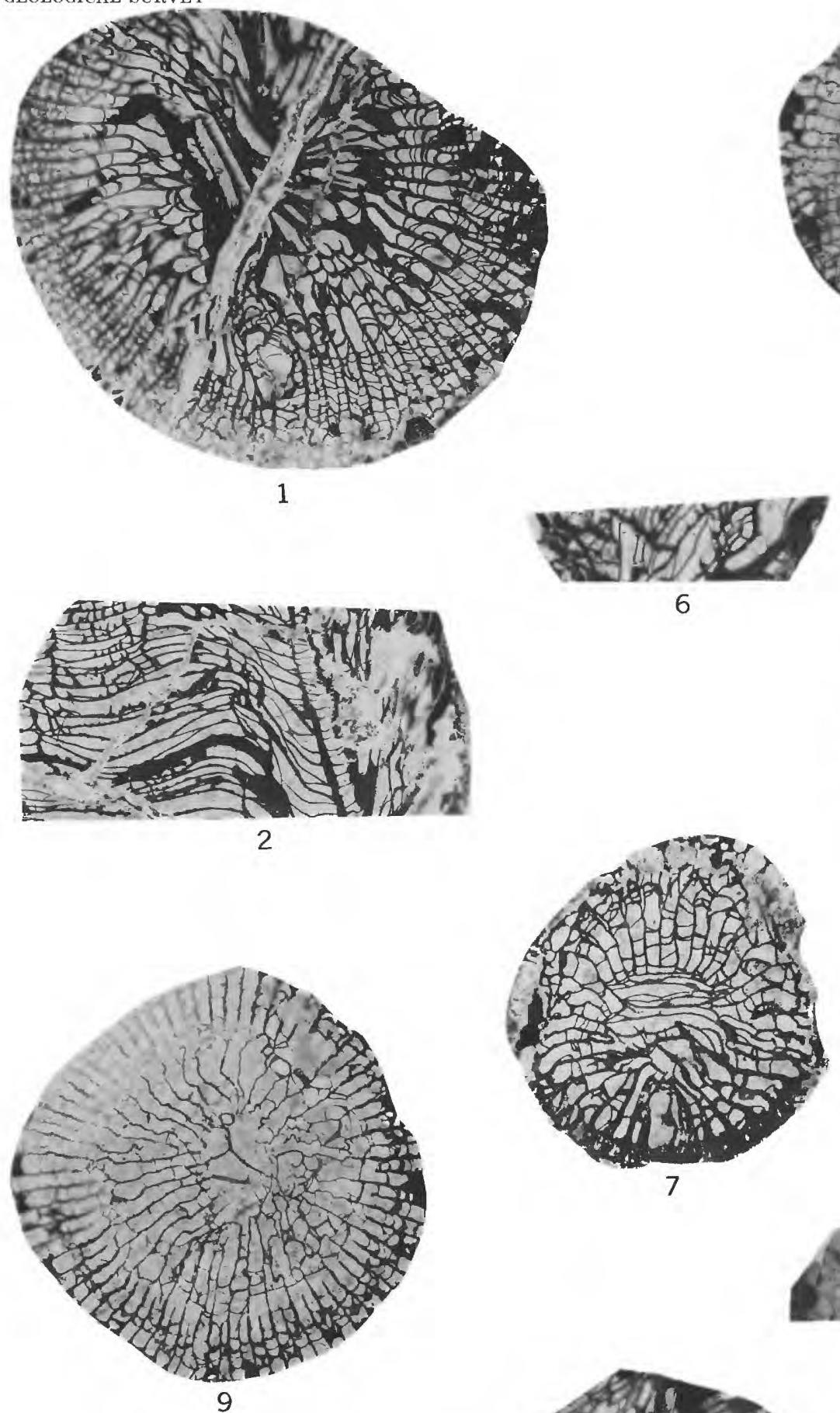

6

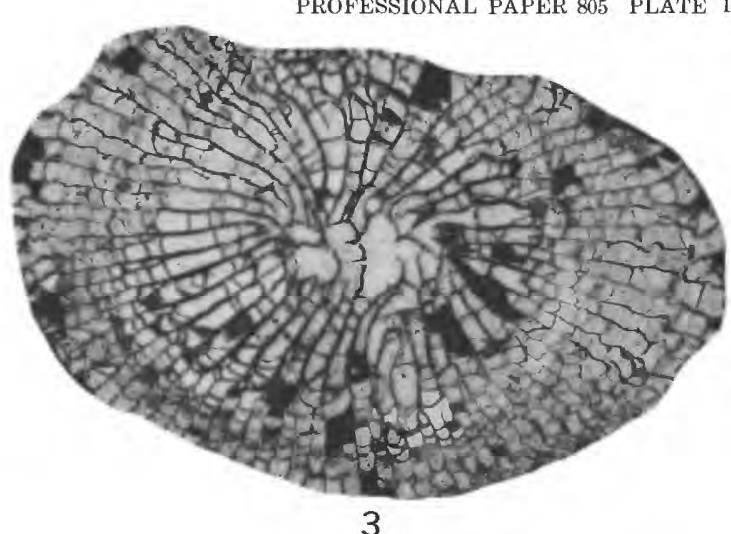

3
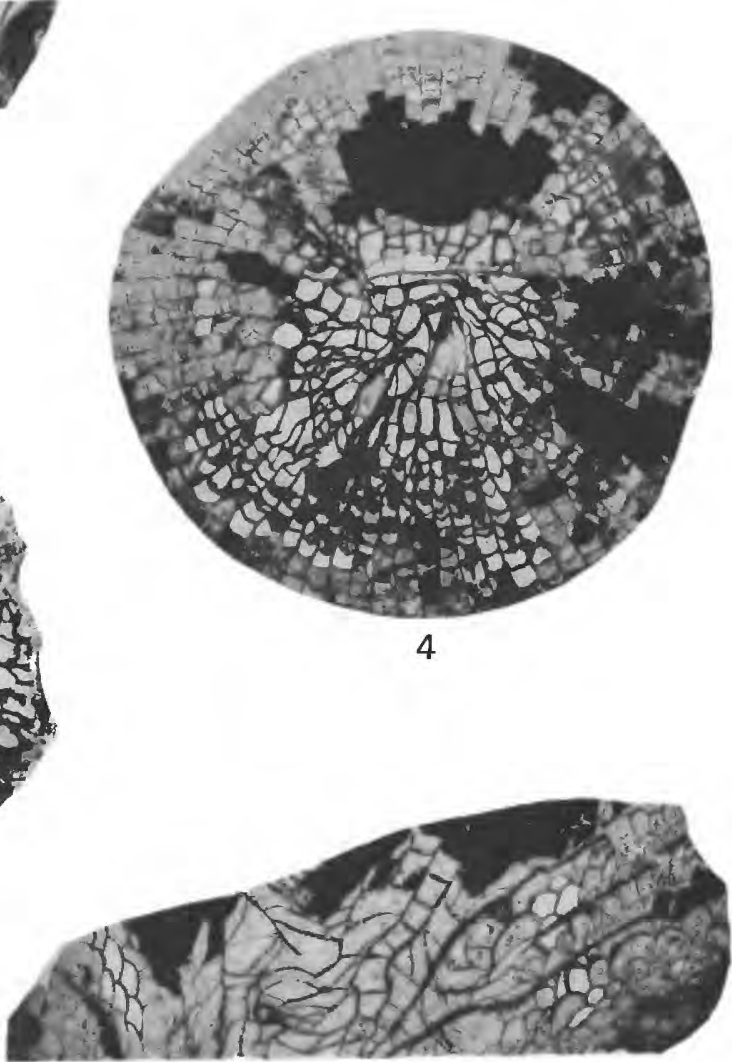

5

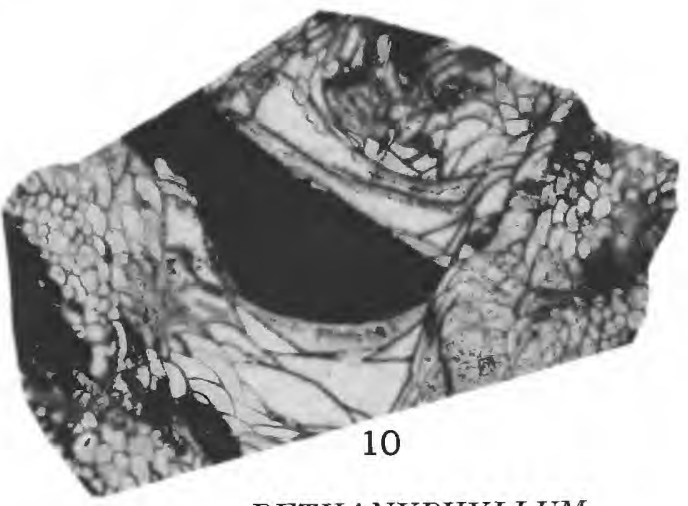

BETHANYPHYLLUM

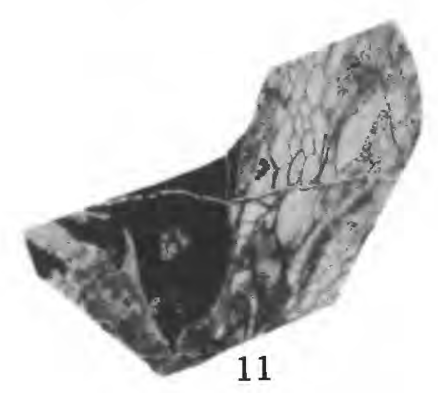




\section{PLATE 13}

Figures 1, 2. (?) Kodonophyllum sp. f.

1. Transverse smoothed surface $(\times 1)$. Photographed in water.

2. Transverse thin section $(\times 3)$.

Early Middle Devonian, Nevada Formation, unit 2; Devonian coral zone D. Locality M1033, north end of Fenstermaker Mountain, Fish Creek Range, Nev.

3,4. Nevadaphyllum masoni Stumm.

3. Transverse thin section $(\times 11 / 2)$ of holotype, USNM 94447.

4. Longitudinal thin section $(\times 3)$ of paratype, USNM 94447a.

Early Middle Devonian, Nevada Formation, unit 2; Devonian coral zone D. Lone Mountain, Eureka County, Nev.

5. Nevadaphyllum-like rugose coral.

Transverse thin section $(\times 2)$, USNM 159280. Early Middle Devonian, Devonian, Nevada Formation, unit 2; Devonian coral zone D. Locality M1049, Lone Mountain, Eureka County, Nev.

6, 7. Bethanyphyllum sp. d.

Transverse and longitudinal thin sections $(\times 2)$, USNM 159281. Late Early Devonian, Nevada Formation; Devonian coral zone $\mathrm{D}_{1}$. Locality M1037, pediment slopes, south side Lone Mountain, Eureka County, Nev.

8. Bethanyphyllum cf. B. lonense (Stumm).

Transverse thin section $(\times 11 / 2)$, USNM 159282. Early Middle Devonian, Nevada Formation, unit 2; Devonian coral zone D. Locality M1050, Lone Mountain, Eureka County, Nev.

9. Bethanyphyllum sp. d.

Longitudinal section $\left(\times 1 \frac{1}{2}\right)$, USNM 159281a. Same horizon and locality as figures 6,7 . 

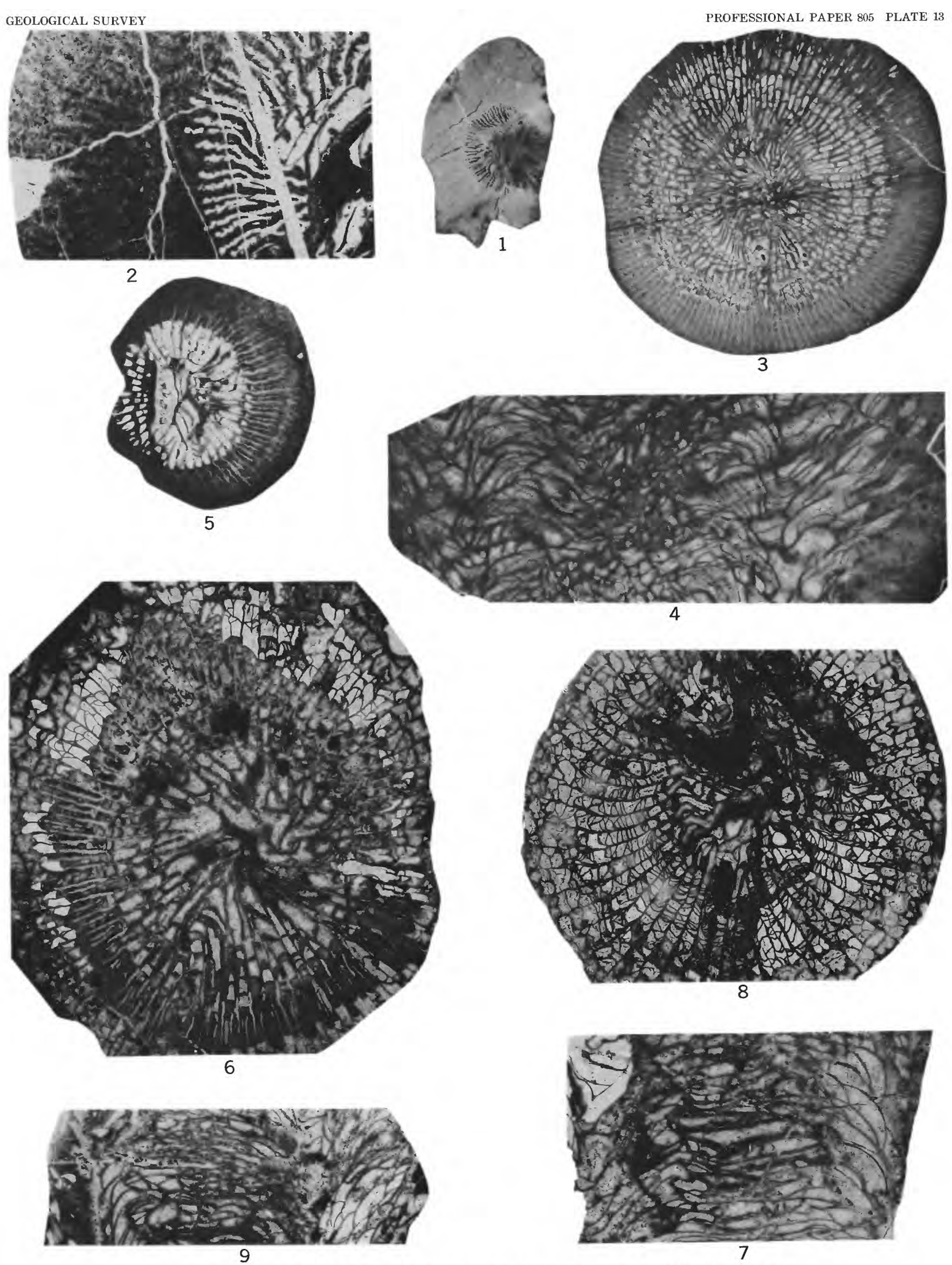

(?)KODONOPHYLLUM, NEVADAPHYLLUM, NEVADAPHYLLUM-LIKE RUGOSE CORAL, AND BETHANYPHYLLUM 


\section{PLATE 14}

FIGURES 1-15. Siphonophrentis (Breviphrentis) kobehensis n. sp.

1. Lateral view of paratype (× 1), USNM 159283.

2. Lateral view of holotype $(\times 1)$, USNM 159284.

Early Devonian, Nevada Formation, unit 1; Devonian coral zone C. Locality M286, northwest side of Lone Mountain, Eureka County, Nev.

3. Lateral view of paratype ( $\times 1$ ), USNM 159285 .

Early Devonian, Nevada Formation, unit 1; Devonian coral zone C. Locality M74, west side of Lone Mountain, Eureka County, Nev.

4. Lateral view of paratype ( $\times 1$ ), USNM 159286. Same horizon and locality as figures 1,2 .

5. Lateral view of paratype $(\times 1)$, USNM 159287. Same horizon and locality as figures 1,2 .

6. Calice view of paratype $(\times 1)$, USNM 159288. Same horizon and locality as figures 1,2 .

7. Calice view of paratype $(\times 1)$, USNM 159289. Same horizon and locality as figures $1,2$.

8. Longitudinal thin section of paratype $(\times 2)$, USNM 159290. Same horizon and locality as figures 1,2 .

9,10 . Transverse and longitudinal thin sections of paratype $(\times 4)$, USNM 159291. Same horizon and locality as figure 3.

11. Longitudinal thin section of paratype $(\times 2)$, USNM 159292. Same horizon and locality as figure 3 .

12. Longitudinal thin section of paratype $(\times 4)$, USNM 159293. Same horizon and locality as figure 3 .

13, 14. Two early neanic transverse thin sections ( $\times 7$ ), USNM 159294. Same horizon and locality as figure 3.

15. Nepionic transverse thin section $(\times 7)$, USNM 159295. Same horizon and locality as figure 3. 

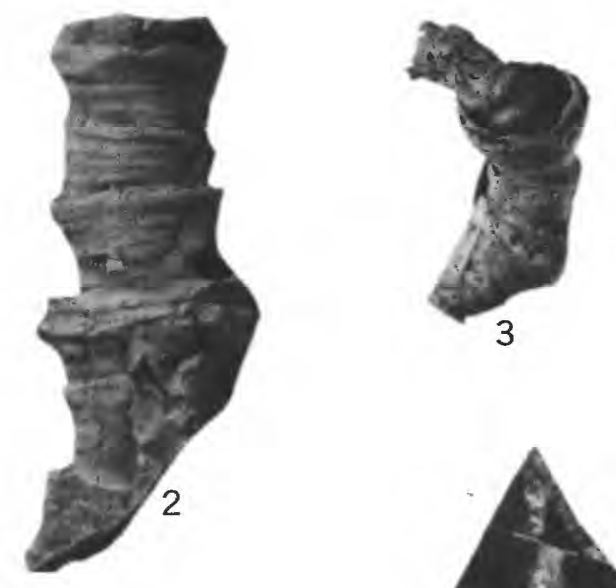

PROFESSIONAL PAPER 805 PLATE 14
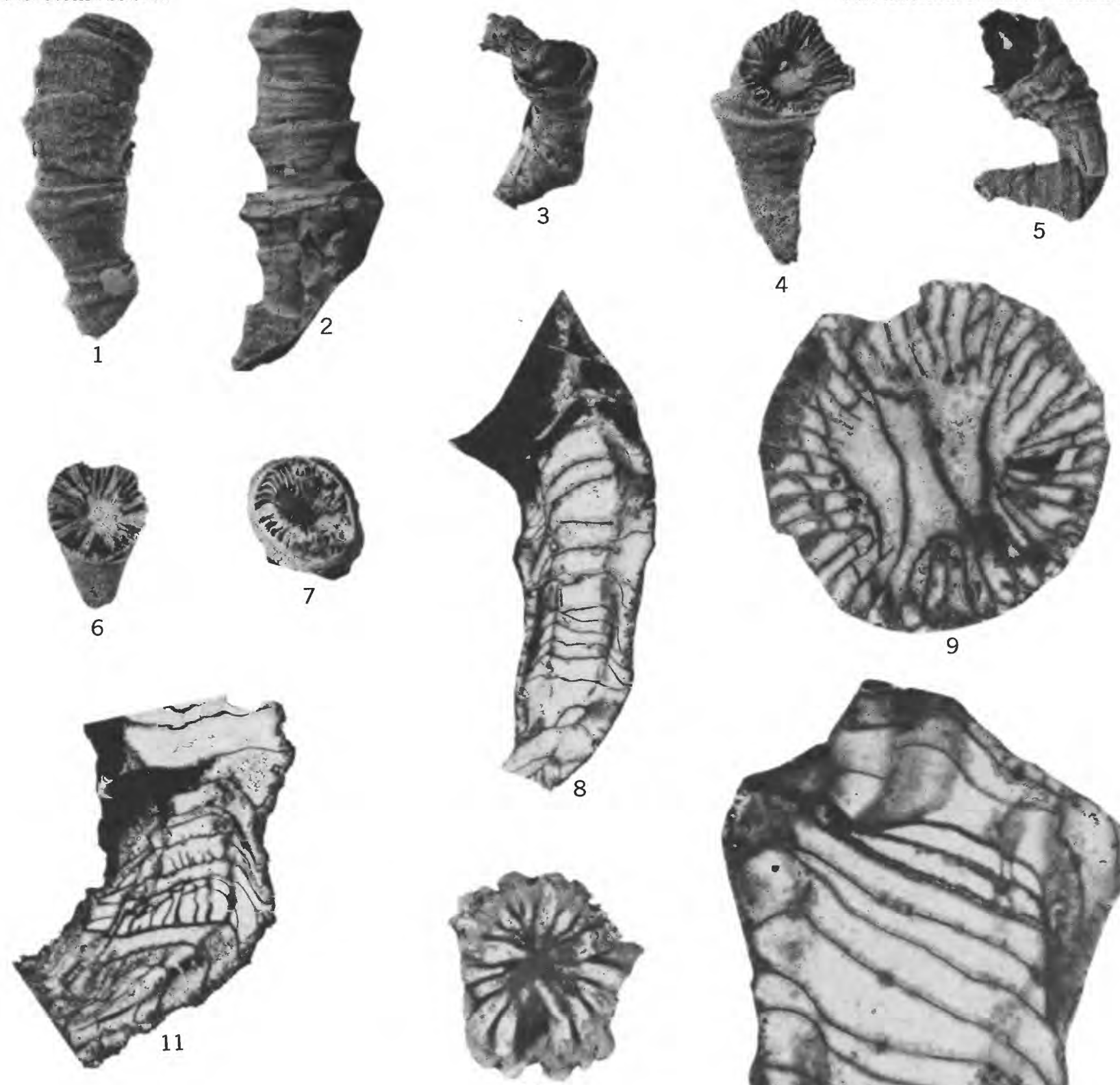

13
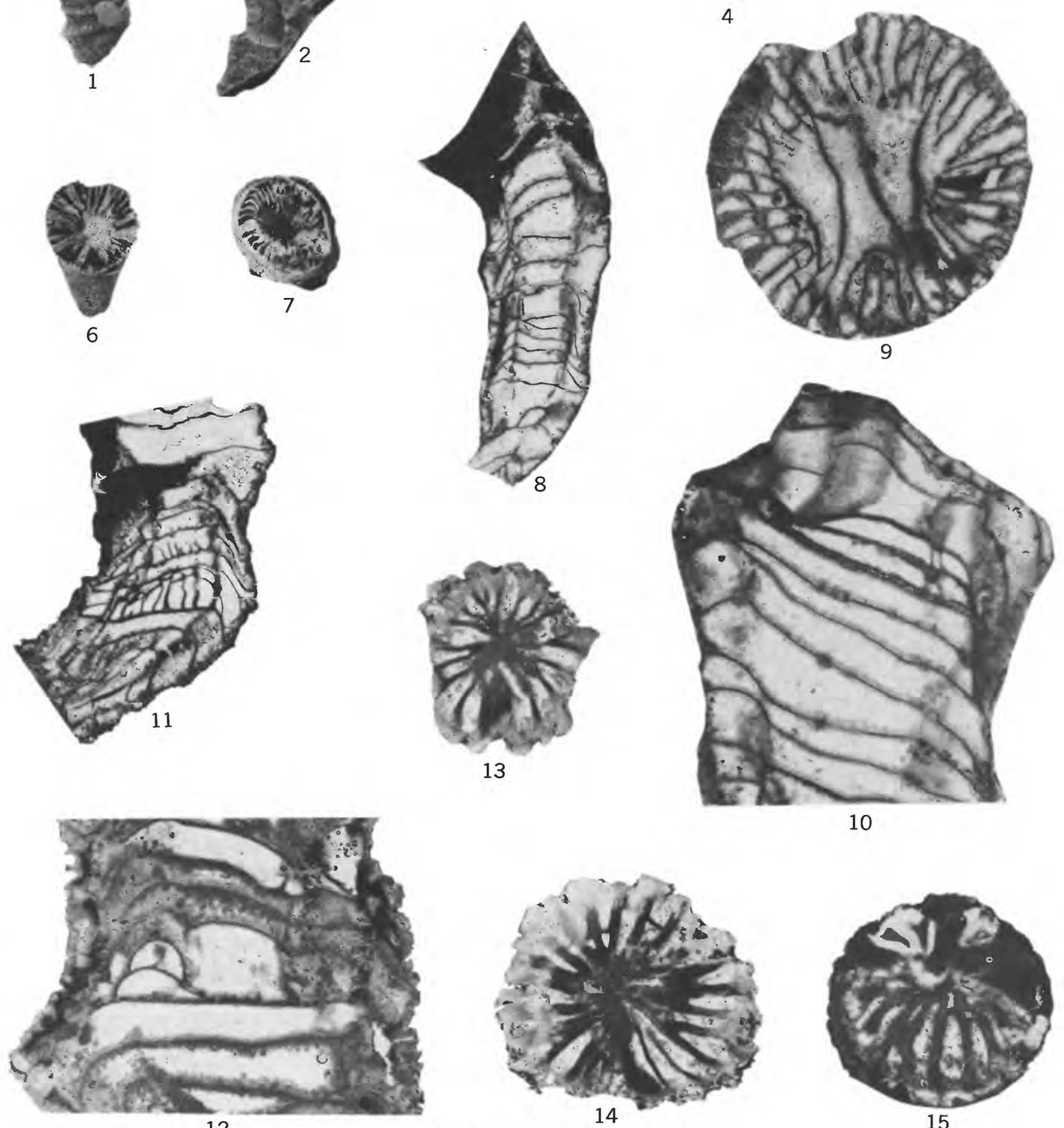

12

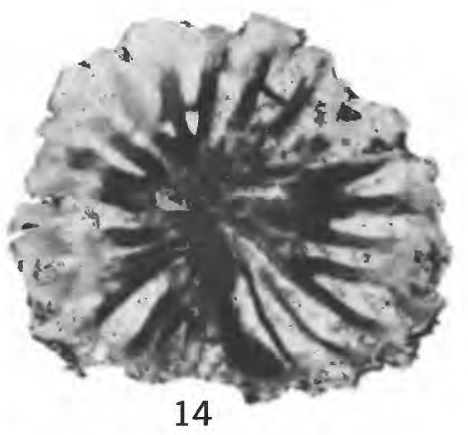

SIPHONOPHRENTIS (BREVIPHRENTIS)

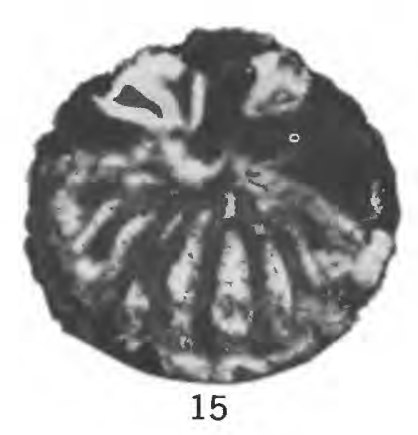




\section{PLATE 15}

FIGURES 1-11. Siphonophrentis (Breviphrentis) invaginatus (Stumm).

1,2. Transverse thin section $(\times 2)$ and longitudinal thin section ( $\times$ 4), USNM 159296.

Early Middle Devonian, Nevada Formation, unit 2; Devonian coral zone D. Locality M1033, north end of Fenstermaker Mountain, Fish Creek Range, Nev.

3 ,4. Transverse thin section $(\times 4)$ and longitudinal thin section $(\times 2)$, USNM 159297.

Early Middle Devonian, Nevada Formation, unit 2; Devonial coral zone D. Locality M198, southern Sulphur Spring Range, Nev.

5,6. Transverse and longitudinal thin sections $(\times 2)$, USNM 159298. Devonian coral zone D. Locality M1034, Ranger Mountains, Nevada Test Site.

7,8. Transverse and longitudinal thin sections ( $\times 2$ ), USNM 159299 . Same horizon and locality as figures 1,2 .

9. Transverse section $(\times 2)$, USNM 159300. Early Middle Devonian, Nevada Formation, unit 2; Devonian coral zone $\mathbf{D}_{2}$. Locality M3, Grays Canyon, southern Eureka district, Nev.

10. Longitudinal thin section $(\times 2)$, USNM 159301. Devonian coral zone D. Locality M1035, north end Antelope Range, Eureka County, Nev.

11. Longitudinal thin section $(\times 2)$, USNM 159302. Same horizon and locality as figure 9. 
GEOLOGICAL SURVEY
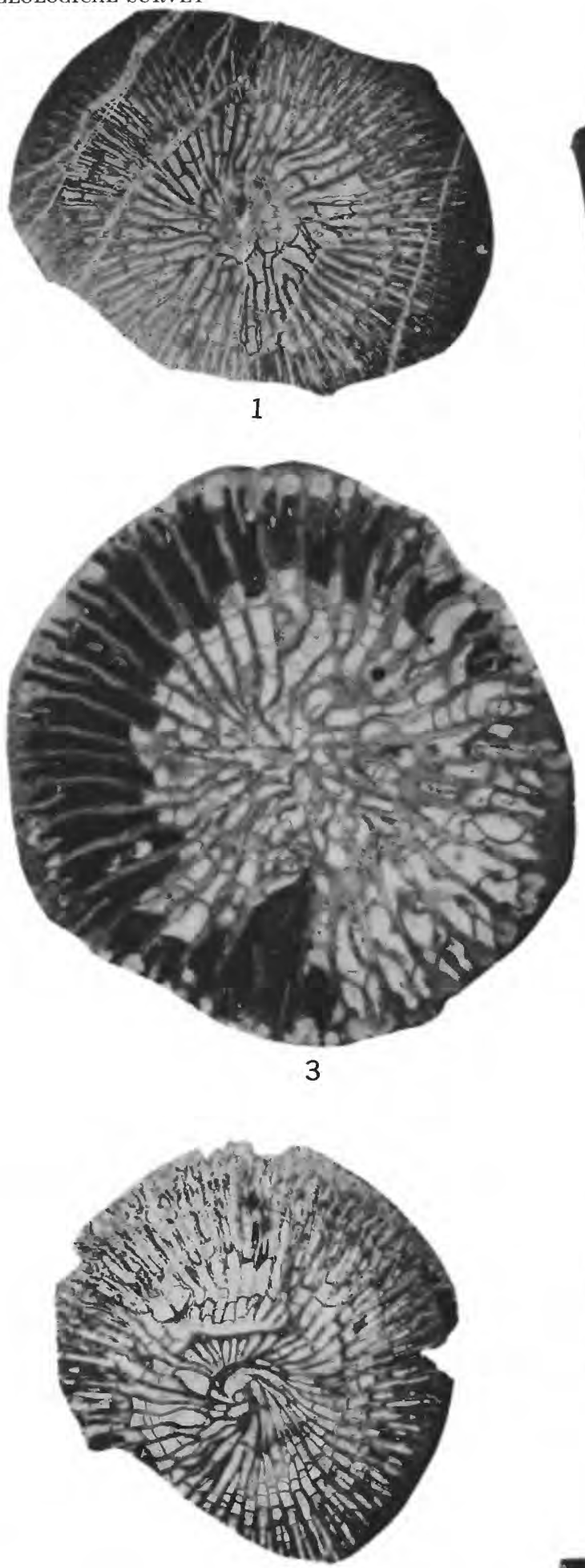

7

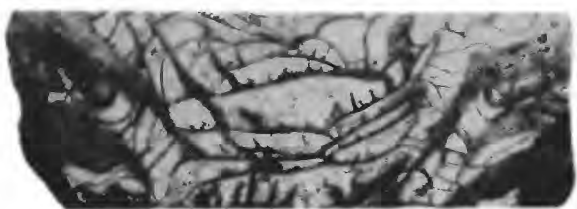

8

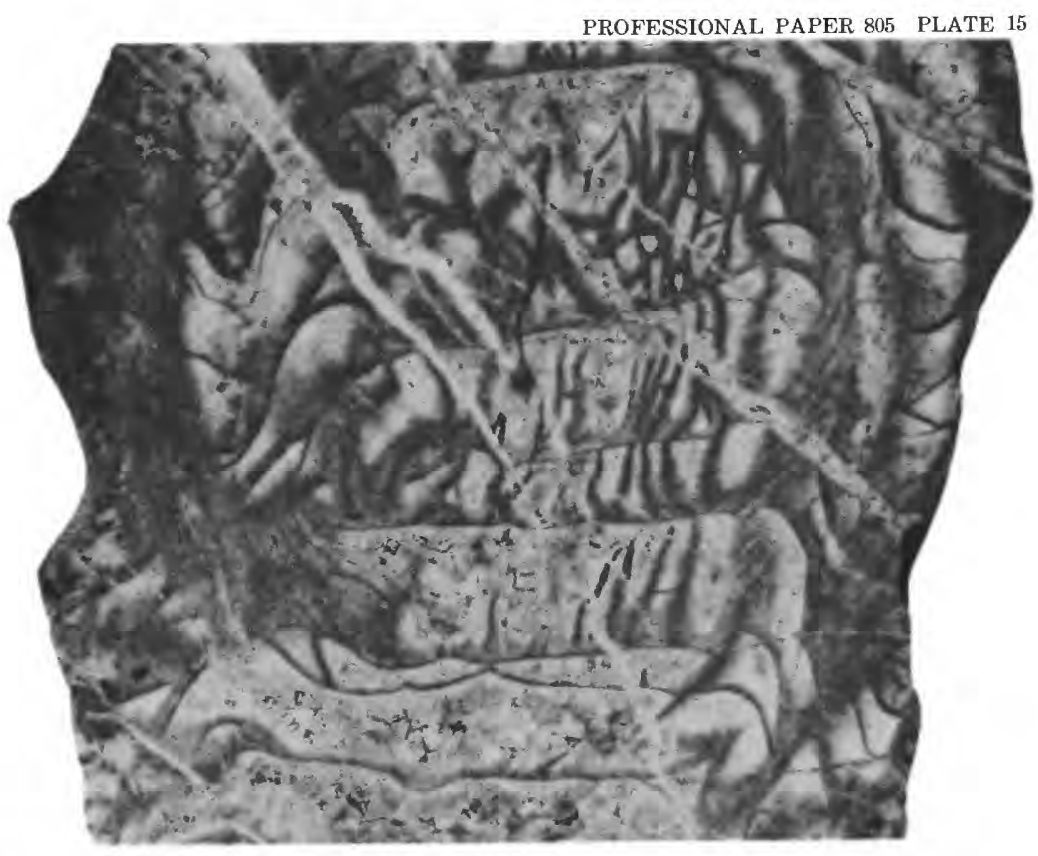

2
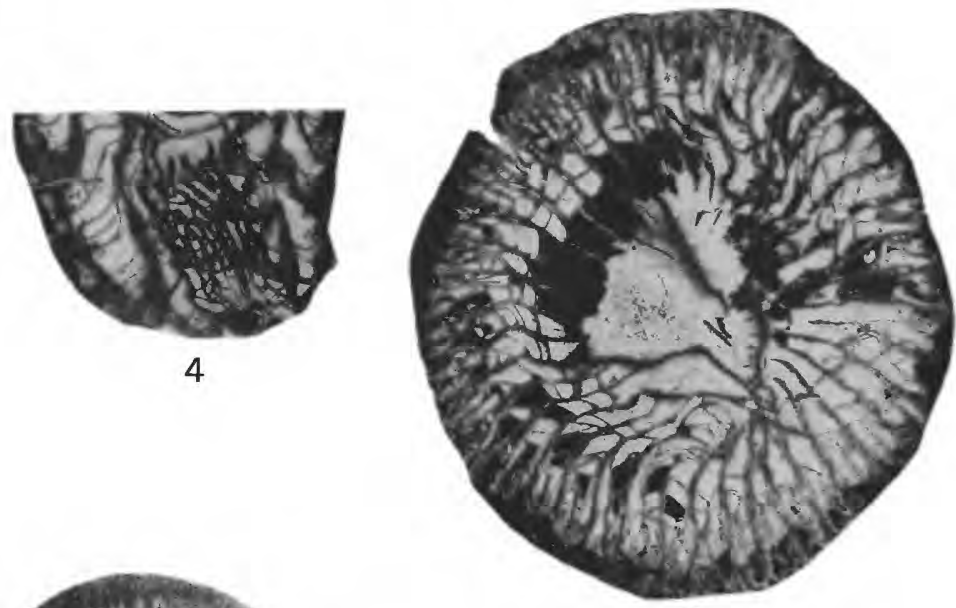

5

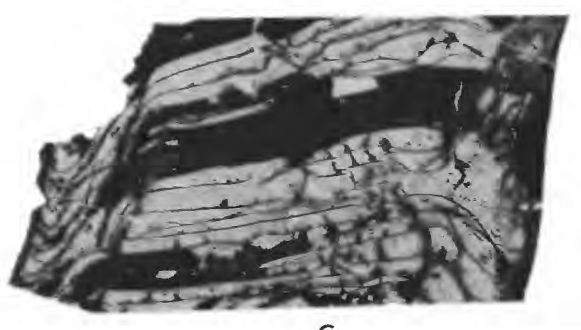

6

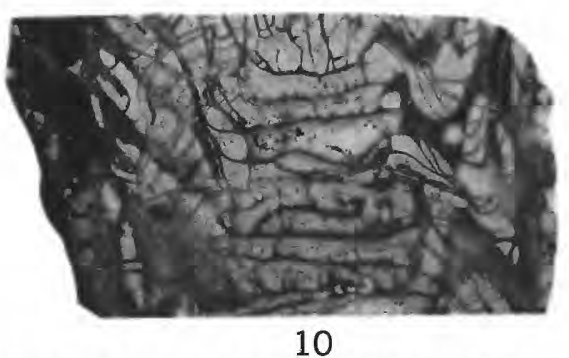

10

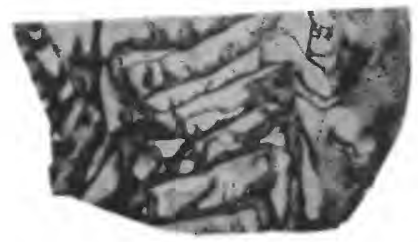

11

SIPHONOPHRENTIS (BREVIPHRENTIS) 


\section{PLATE 16}

FIgURES 1-13. Siphonophrentis (Breviphrentis) invaginatus (Stumm).

1,2. Transverse and longitudinal thin sections ( $\times 2)$, USNM 159303, Early Middle Devonian, Nevada Formation, unit 2; Devonian coral zone $\mathrm{D}_{2}$. Locality M55, Lone Mountain, Eureka County, Nev.

3. Transverse thin section $(\times 2)$, USNM 159304.

Early Middle Devonian, Nevada Formation, unit 2; Devonian coral zone $\mathbf{D}_{2}$. Locality $\mathrm{M} 3$, Grays Canyon, southern Eureka district, Nevada.

4. Longitudinal thin section $(\times 2)$, USNM 159305. Same horizon and locality as figure 3 .

5-7. Transverse thin section $(\times 2)$, longitudinal thin section $(\times 2)$, and transverse thin section of neanic stage $(\times 4)$, USNM 159306. Same horizon and locality as figure 3.

8. Transverse thin section $(\times 2)$, USNM 159307. Same horizon and locality as figure 3 .

9. Transverse thin section $(\times 2)$, USNM 159308. Same horizon and locality as figure 3 .

10, 11. Transverse and longitudinal thin section ( $\times 2$ ), USNM 159309.

Early Middle Devonian, Nevada Formation, unit 2; Devonian coral zone $\mathrm{D}_{2}$. Locality M1033, north end Fenstermaker Mountain, Fish Creek Range, Nev.

12,13. Transverse and longitudinal thin sections $(x 2)$, USNM 159310.

Early Middle Devonian, Nevada Formation, unit 2; Devonian coral zone $D_{2}$. Locality M27, Combs Peak, southern Mahogany Hills, Eureka County, Nev.

14. Siphonophrentis (Breviphrentis) kobehensis $\mathrm{n} . \mathrm{sp}$.

Transverse thin section of paratype $(\times 2)$, USNM 159283. Early Devonian, Nevada Formation, unit 1; Devonian coral zone C. Locality M286, northwest side of Lone Mountain, Eureka County, Nev.

15, 16. Siphonophrentis (Breviphrentis) invaginatus (Stumm).

Transverse and longitudinal thin sections ( $\times 2$ ), USNM 159311. Early Middle Devonian, Nevada Formation, unit 2; Devonian coral zone $\mathrm{D}_{2}$. Locality M1036, Lone Mountain, Eureka County, Nev. 
GEOLOGICAL SURVEY
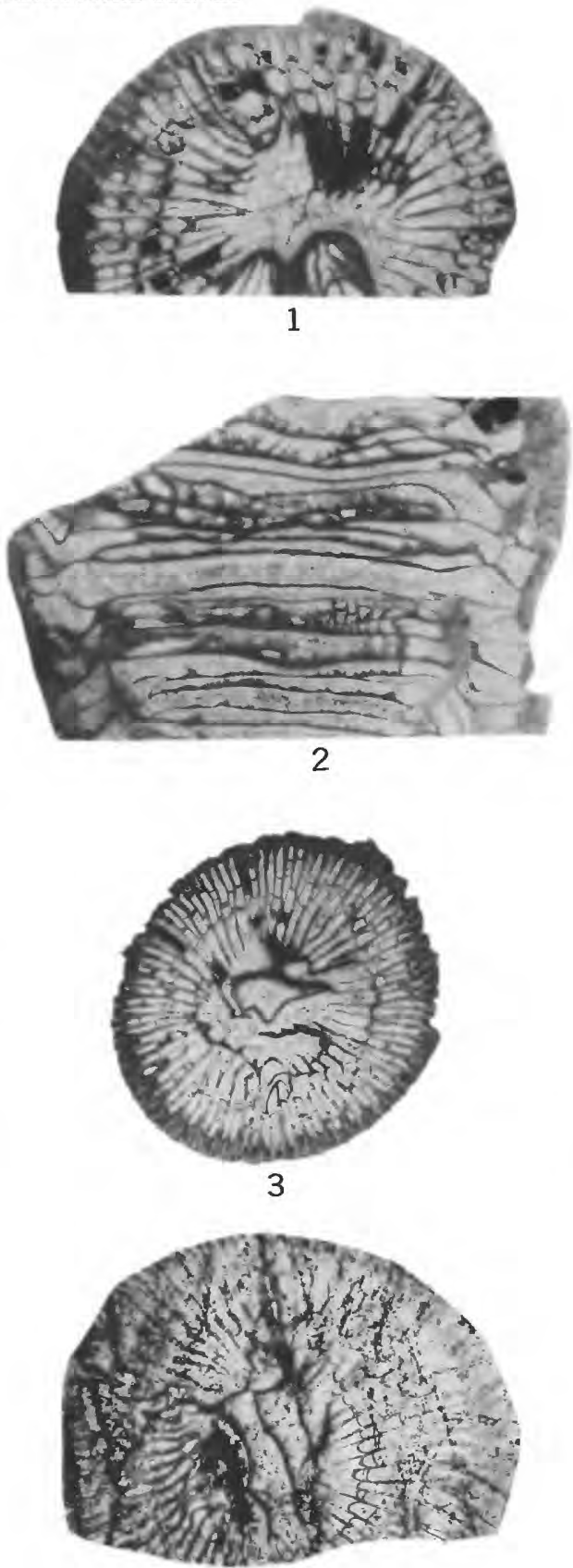

12

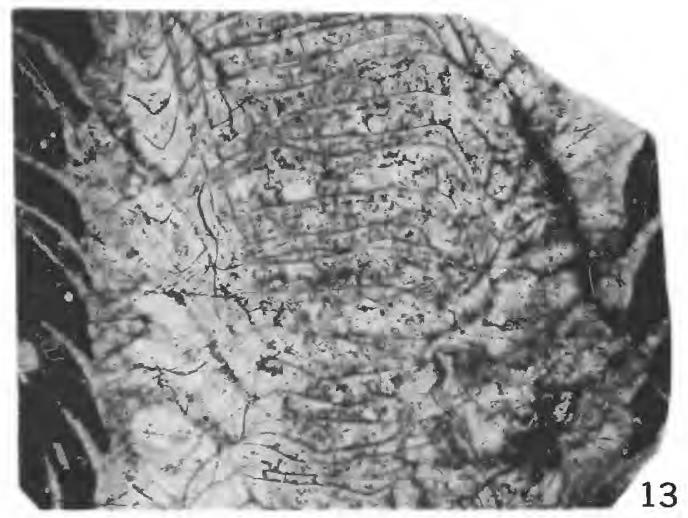

SIPHONOPHRENTIS (BREVIPHRENTIS)
PROFESSIONAL PAPER 805 PLATE 16
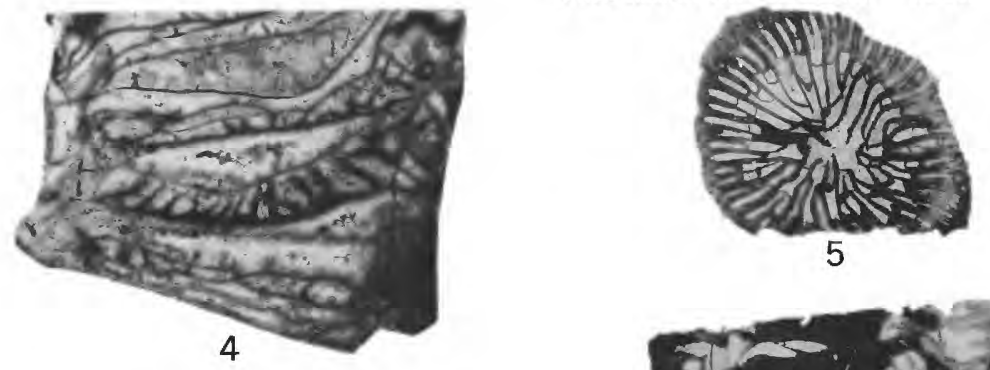

5
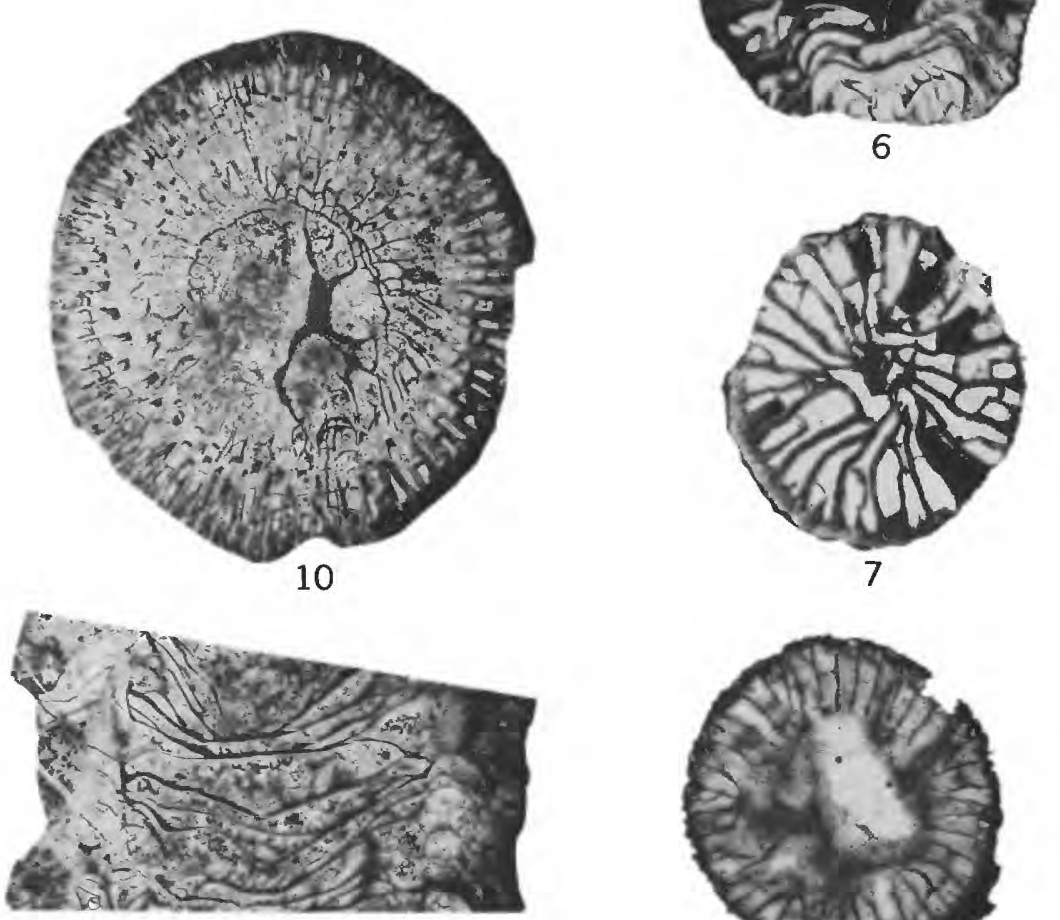

11
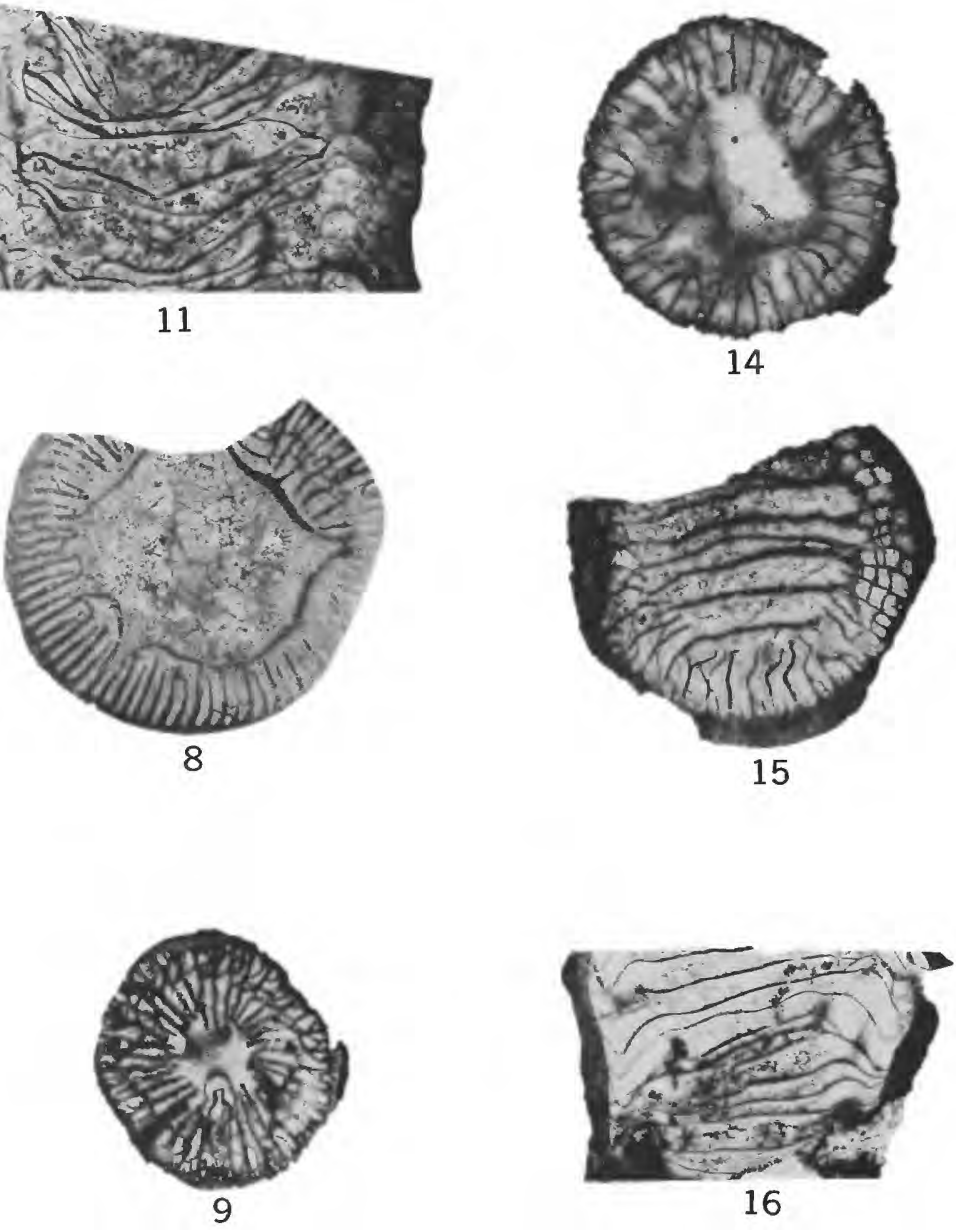


\section{PLATE 17}

Figures 1,2. Sinospongophyllum sp. d.

Longitudinal and transverse thin sections $(\times 2)$, USNM 159312. Late Early Devonian, Nevada Formation, unit 2; Devonian coral zone $\mathbf{D}_{1}$. Locality M1037, south pediment slope, Lone Mountain, Eureka County, Nev.

3,4. Sinospongophyllum sp. e.

Transverse and longitudinal thin sections ( $\left.\times 1 \frac{1}{2}\right)$, USNM 159313. Early Middle Devonian, Nevada Formation, unit 2; Devonian coral zone $\mathrm{D}_{2}$. Locality M1038, Lone Mountain, Eureka County, Nev.

5,6. Sinospongophyllum $\mathrm{sp}$. d.

Longitudinal and transverse thin sections $(\times 2)$, USNM 159314. Early Middle Devonian, Nevada Formation, unit 2; Devonian coral zone $\mathrm{D}_{2}$. Locality M1035, north end Antelope Range, southern Eureka County, Nev.

7. Sinospongophyllum sp. f.

Transverse thin section $(\times 2)$, USNM 159315. Early Middle Devonian, Nevada Formation, unit 2; Devonian coral zone $\mathbf{D}_{2}$. Locality M3, Grays Canyon, southern Eureka district, Nevada.

8, 9. Sinospongophyllum sp. f.

Transverse and longitudinal thin sections $(\times 2)$, USNM 159316. Early Middle Devonian, Nevada Formation, unit 2; Devonian coral zone $\mathrm{D}_{2}$. Locality M1035, north end Antelope Range, southern Eureka County, Nev

10, 11. Sinospongophyllum sp. e.

Transverse and longitudinal thin sections $(\times 2)$, USNM 159317. Early Middle Devonian, Nevada Formation, unit 2; Devonian coral zone $\mathbf{D}_{2}$. Locality M1035, north end Antelope Range, southern Eureka County, Nev.

12,13. Siphonophrentis (Breviphrentis) invaginatus (Stumm).

Transverse and longitudinal thin sections $(\times 2)$, USNM 94445. Holotype of Amplexus lonensis Stumm which is the type species of Breviphyllum Stumm 1949. Nevada Formation, Lone Mountain, Eureka County, Nev. 

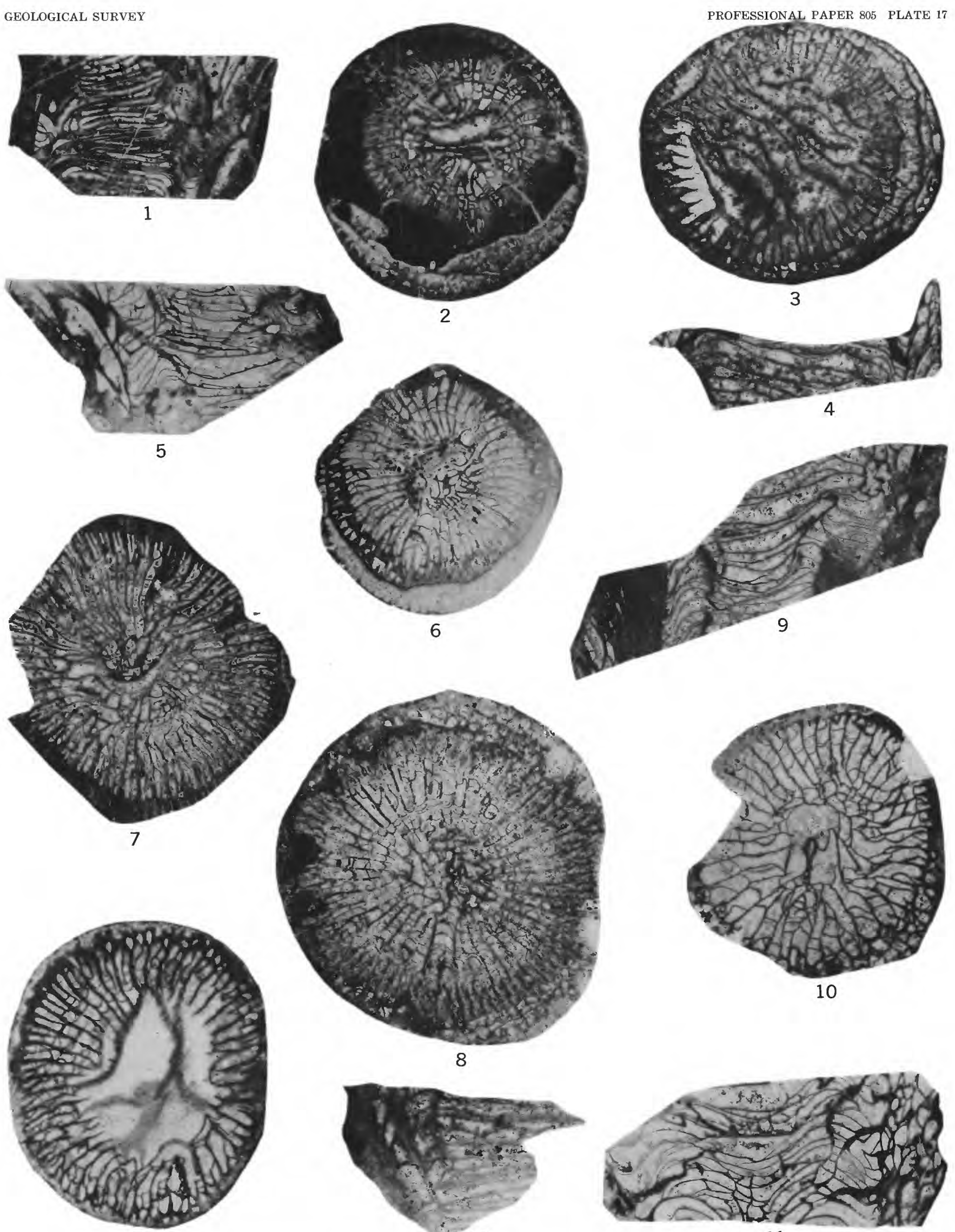

12
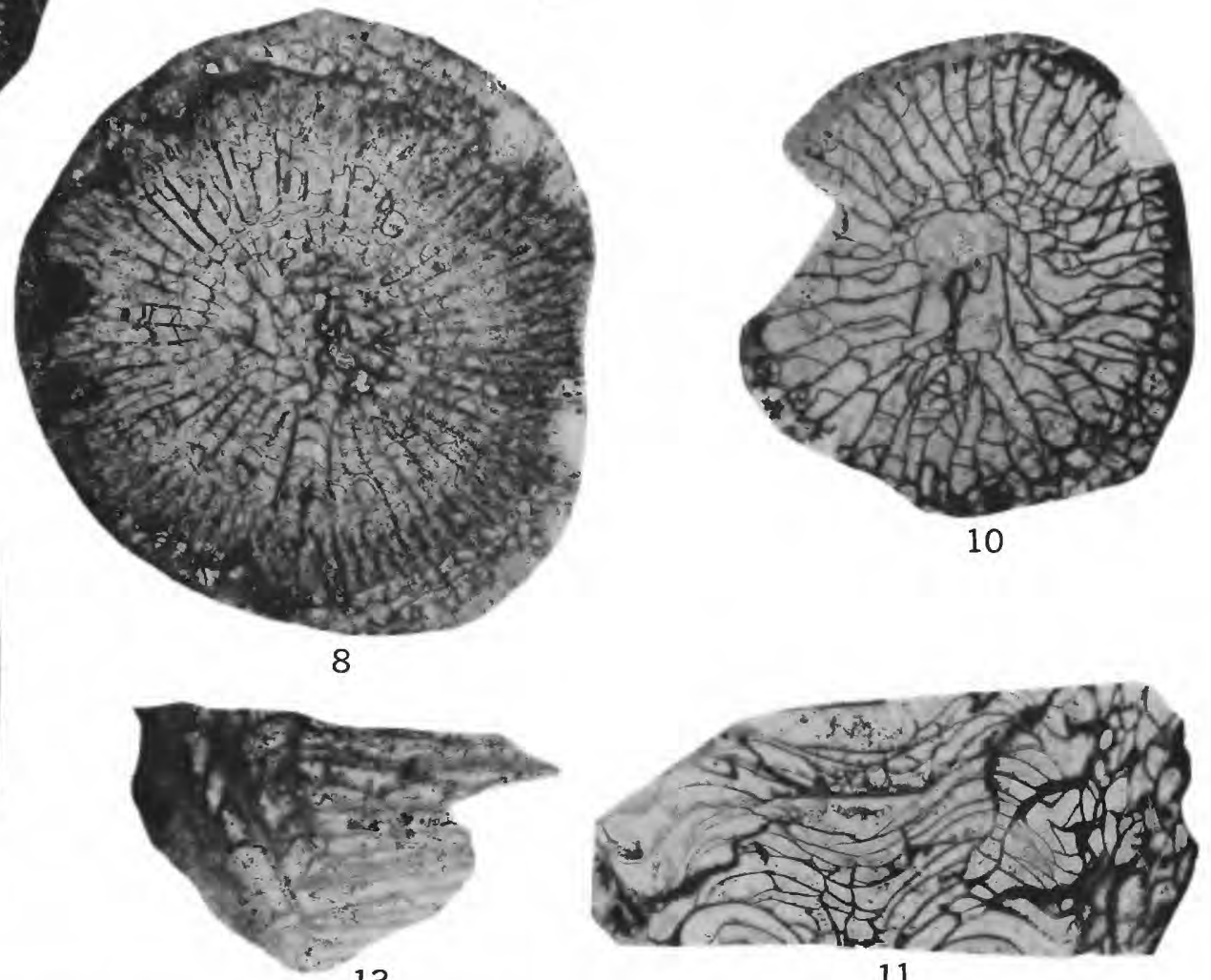

13

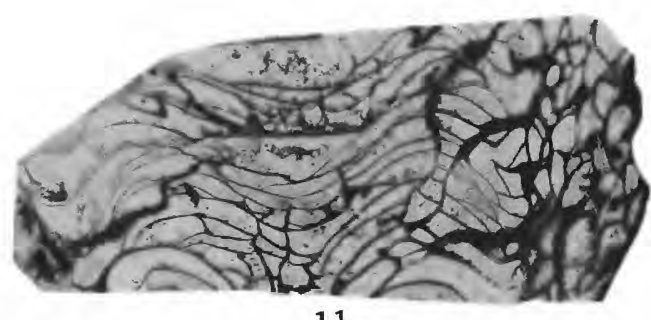

11

SINOSPONGOPHYLLUM AND SIPHONOPHRENTIS (BREVIPHRENTIS) 


\section{PLATE 18}

Figures 1-4. Dendrostella romanensis $\mathrm{n} . \mathrm{sp}$.

Transverse and longitudinal thin sections of holotype $(\times 2)$, USNM 159318. Middle Devonian, Nevada Formation. Devonian coral zone D. Locality M1031, southern Sulphur Spring Range, northwest of Romano Ranch, Eureka County, Nev.

5,6. Disphyllum eurekaensis $\mathrm{n}$. sp.

Transverse and longitudinal thin sections of holotype $(\times 4)$, USNM 159319. Early Middle Devonian, Nevada Formation, unit 2; Devonian coral zone $\mathrm{D}_{2}$. Locality M1046, Lone Mountain, Eureka County, Nev.

7-10. Disphyllum nevadense (Stumm).

7-9. Transverse and longitudinal thin sections ( $\times 4$ ), USNM 159320. Same horizon and locality as figures 5,6 .

10. Longitudinal thin section $(\times 4)$, USNM 159321. Same horizon and locality as figures 5,6 . 

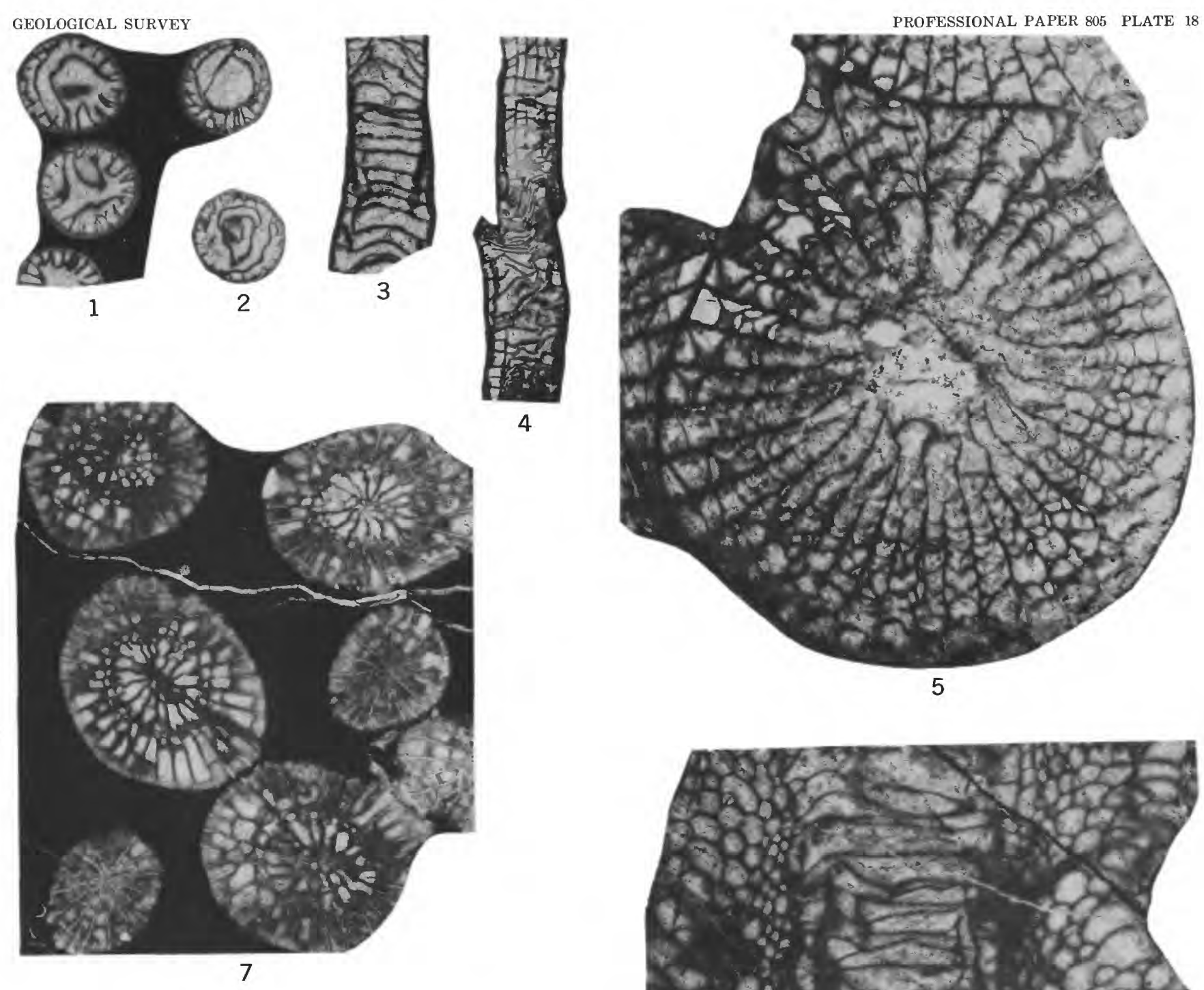

4

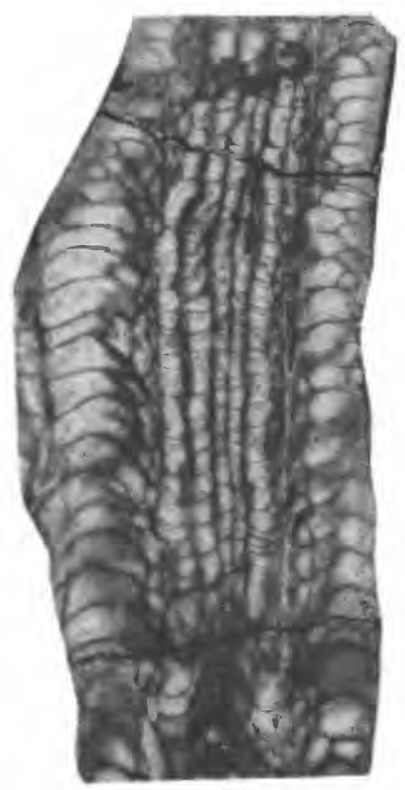

8

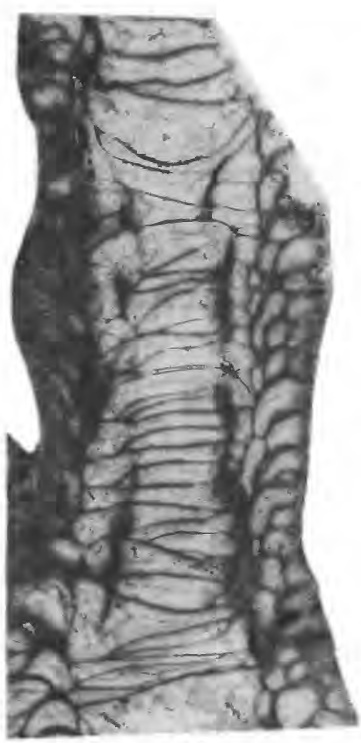

10

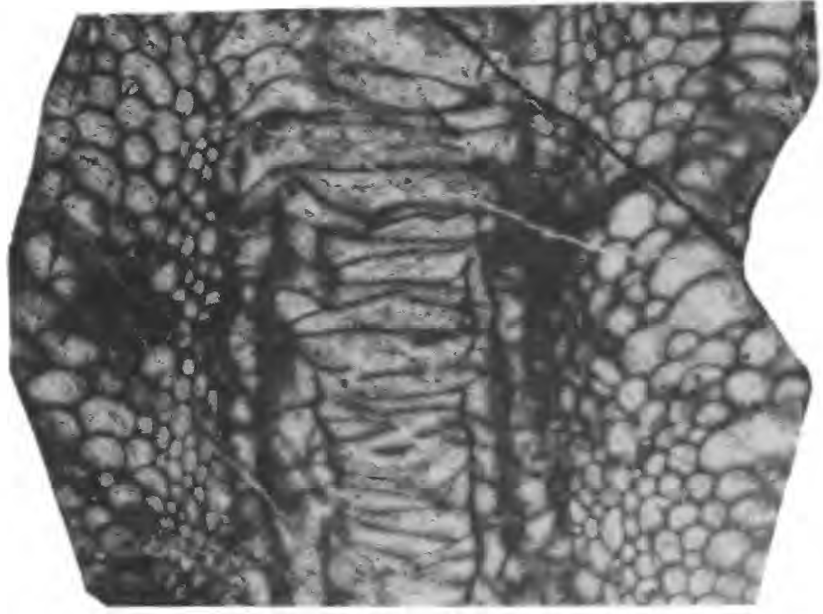

6

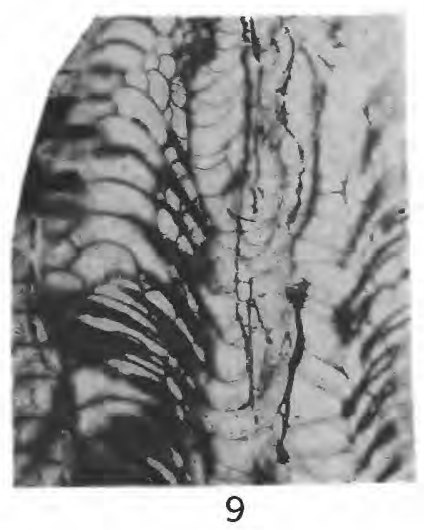

DENDROSTELLA AND DISPHYLLUM 


\section{PLATE 19}

Figures 1-9. Cystiphylloides lonense (Stumm).

1, 2. Calice and lateral views $(\times 1)$, USNM 159322. Early Devonian, Nevada Formation, unit 1; Devonian coral zone C. Locality M74, Lone Mountain, Eureka County, Nev.

3, 4. Lateral and calice views ( $\times 1)$, USNM 159323. Early Devonian, Nevada Formation, unit 1; Devonian coral zone C. Locality M286, Lone Mountain, Eureka County, Nev.

5. Lateral view $(\times 1)$, USNM 159324. Same horizon and locality as figures 3, 4.

6. Transverse thin section $(\times 2)$, USNM 159325. Same horizon and locality as figures $1,2$.

7, 8. Longitudinal and transverse thin sections $(\times 2)$, USNM 159326. Same horizon and locality as figures $1,2$.

9. Longitudinal thin section $(\times 2)$, USNM 159327. Same horizon and locality as figures $1,2$.

10, 11. Cystiphylloides sp. d.

Transverse and longitudinal thin sections $(\times 2)$, USNM 159328. Early Middle Devonian, Nevada Formation, unit 2; Devonian coral zone $\mathrm{D}_{2}$. Locality M36, Sulphur Spring Range, Nev.

12,13. Cystiphylloides sp.

Transverse section and longitudinal section at calice $(\times 11 / 2)$, USNM 159329. Early Middle Devonian, Nevada Formation, unit 2; Devonian coral zone $\mathrm{D}_{2}$. Locality M1048, Lone Mountain, Eureka County, Nev. 

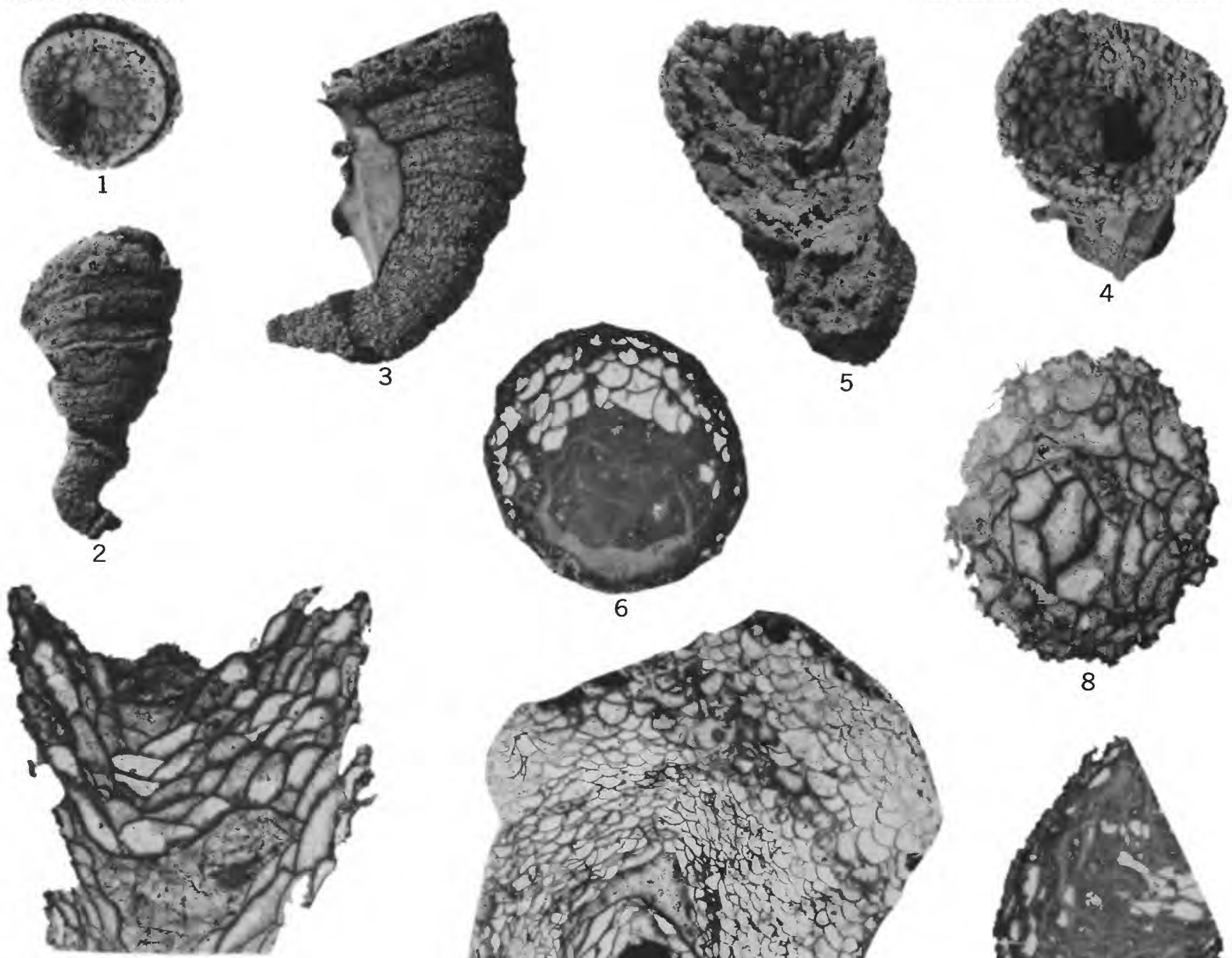

7
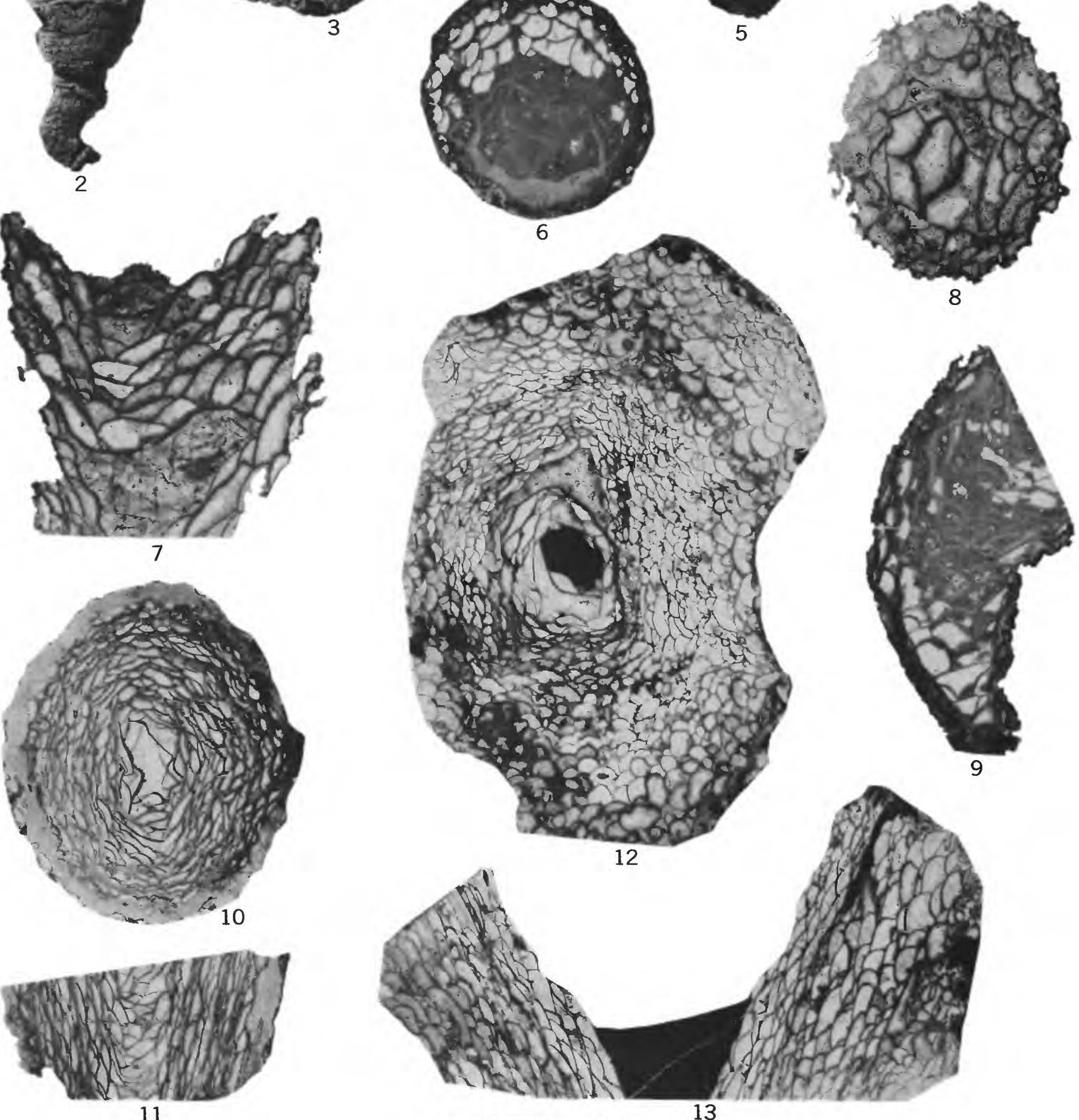

CYSTIPHYLLOIDES 


\section{PLATE 20}

Figures 1,2. Cystiphylloides sp.

Transverse thin section $\left(\times 1 \frac{1}{2}\right)$, longitudinal thin section $(\times 2)$, USNM M159330. Early Middle Devonian, Nevada Formation, unit 2; Devonian coral zone $\mathrm{D}_{2}$. Locality M1051, south end Sulphur Spring Range, Nev.

3,4. Zonophyllum haguei n. sp.

Transverse thin section $(\times 4)$, longitudinal thin section $(\times 2)$ of paratype, USNM 159331. Early Middle Devonian, Nevada Formation, unit 2; Devonian coral zone $\mathrm{D}_{2}$. Locality M51, Grays Canyon, southern Eureka district, Nevada.

5,6. Zonophyllum sp. a.

Longitudinal and transverse thin sections $(\times 2)$, USNM 159332. Early Middle Devonian; Devonian coral zone D. Locality M1058, Nevada Test Site, Frenchman Flat, Nev.

7,8. Zonophyllum of. Z. haguei n. sp.

Longitudinal and transverse thin sections $(\times 2)$. Early Middle Devonian, Nevada Formation, unit 2; Devonian coral zone $\mathbf{D}_{2}$. Locality M1035, north end of Antelope Range, Eureka County, Nev.

9,10. Zonophyllum haguei n. sp.

Transverse and longitudinal thin sections $(\times 2)$ of holotype USNM 159333. Early Middle Devonian, Nevada Formation, unit 2; Devonian coral zone $\mathrm{D}_{2}$. Locality M3, Grays Canyon, southern Eureka district, Nevada.

11, 12. Zonophyllum sp. b.

Transverse thin section $(\times 2)$, longitudinal thin section $(\times 4)$, USNM 159351. Same horizon and locality as figures 3,4 

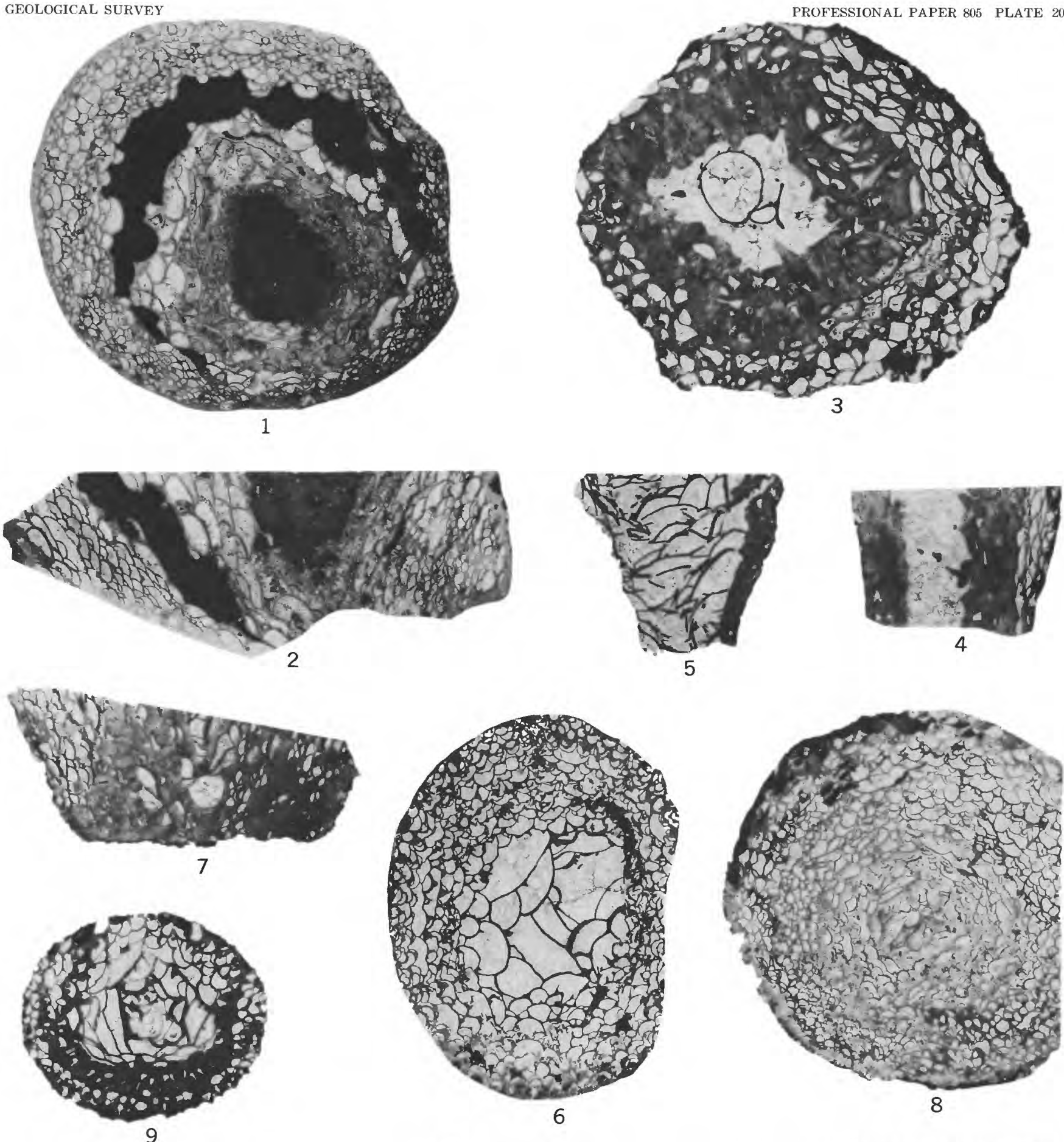

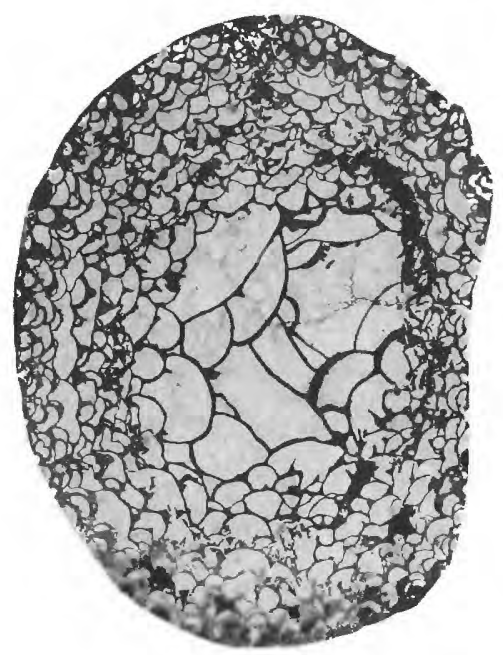

6

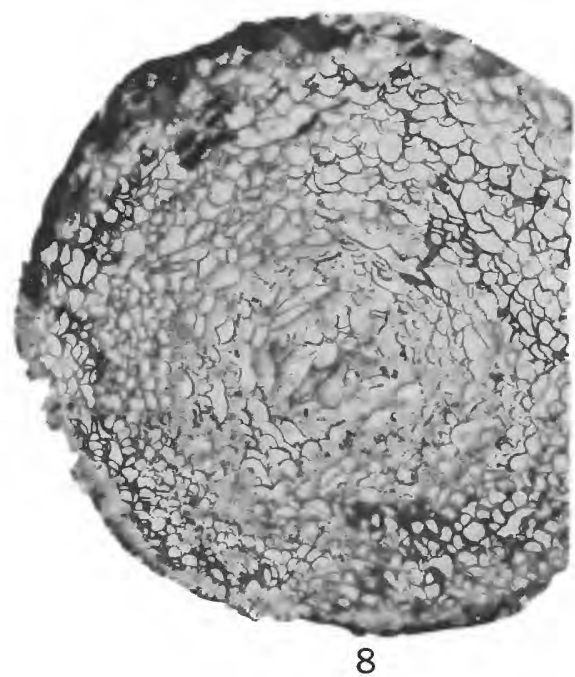

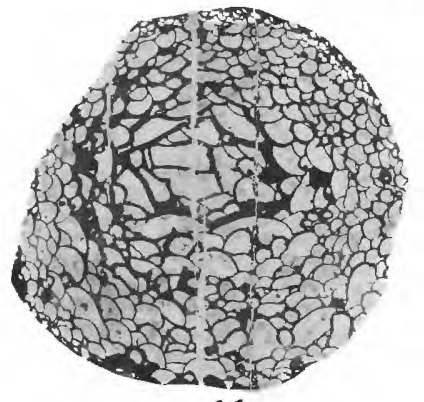

11

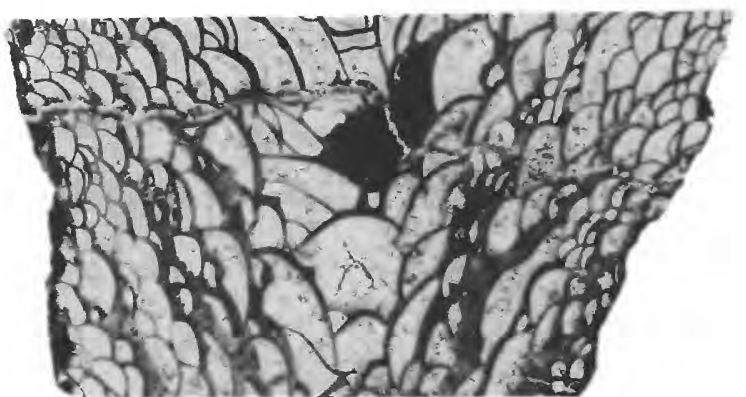

12

CYSTIPHYLLOIDES AND ZONOPHYLLUM 


\section{PLATE 21}

Figures 1,2. Mesophyllum (Mesophyllum) sp. b.

Two transverse thin sections $(\times 2)$, USNM 159334. Early Middle Devonian, Nevada Formation, unit 2; Devonian coral zone $\mathrm{D}_{2}$. Locality M36, southern Sulphur Spring Range, Nev.

3,4. Mesophyllum (Mesophyllum) sp.c.

Transverse and longitudinal thin sections $(\times 2)$, USNM 159335. Early Middle Devonian, Nevada Formation, unit 2; Devonian coral zone D. Locality M1035, north end Antelope Range, Eureka County, Nev.

5-7. Mesophyllum (Arcophyllum) kirki (Stumm).

Transverse and longitudinal thin sections $(\times 2)$ and enlarged transverse thin section $(\times 4)$, USNM 159336. Middle Devonian, Nevada Formation, unit 2; Devonian coral zone $\mathrm{D}_{3}$. Locality M29, Lone Mountain, Eureka County, Nev. 
GEOLOGICAL SURVEY

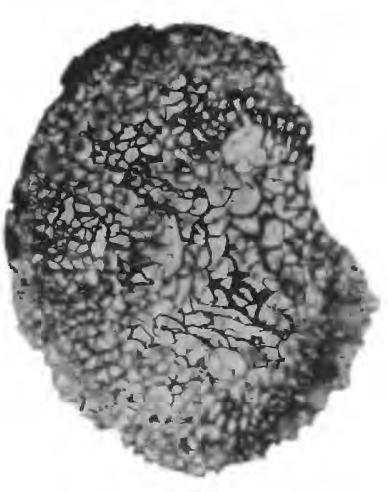

1

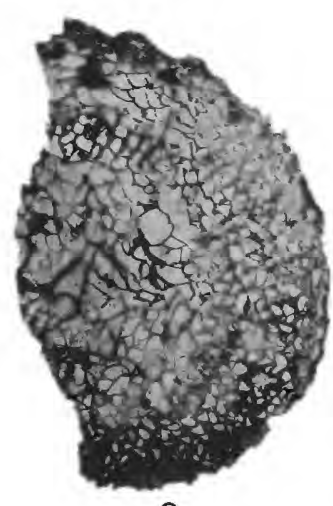

2
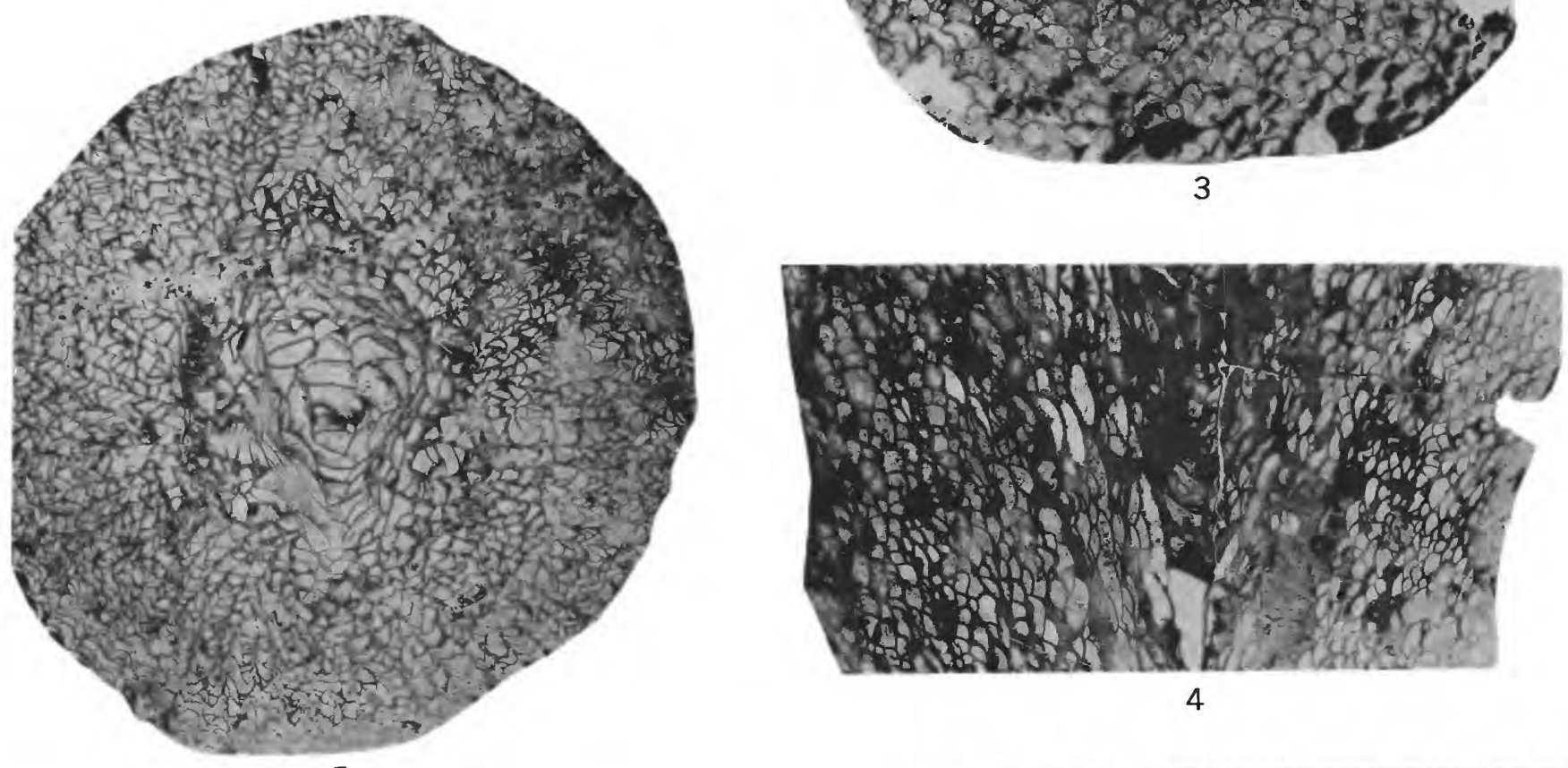

5

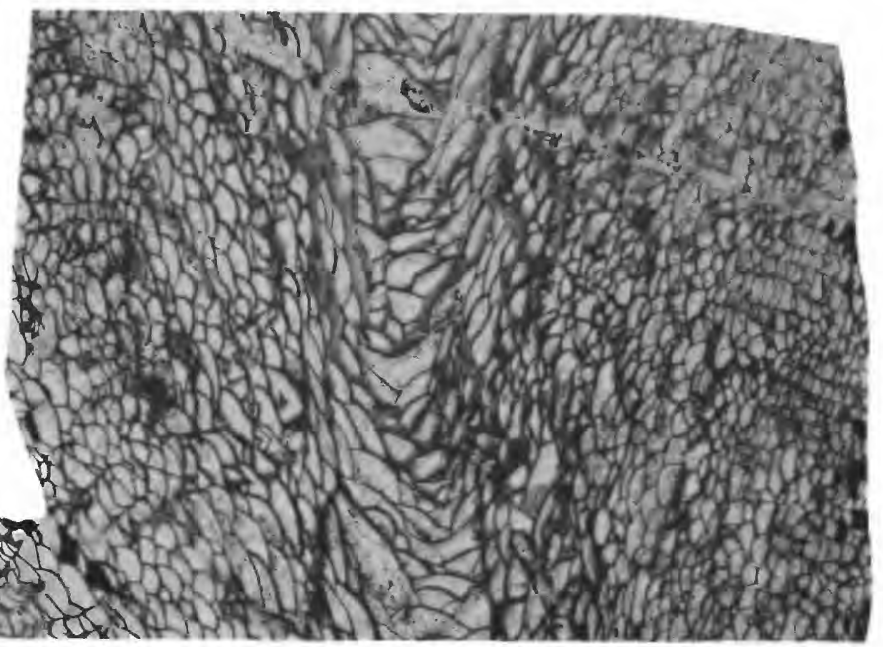

6

MESOPHYLLUM AND MESOPHYLLUM (ARCOPHYLLUM)

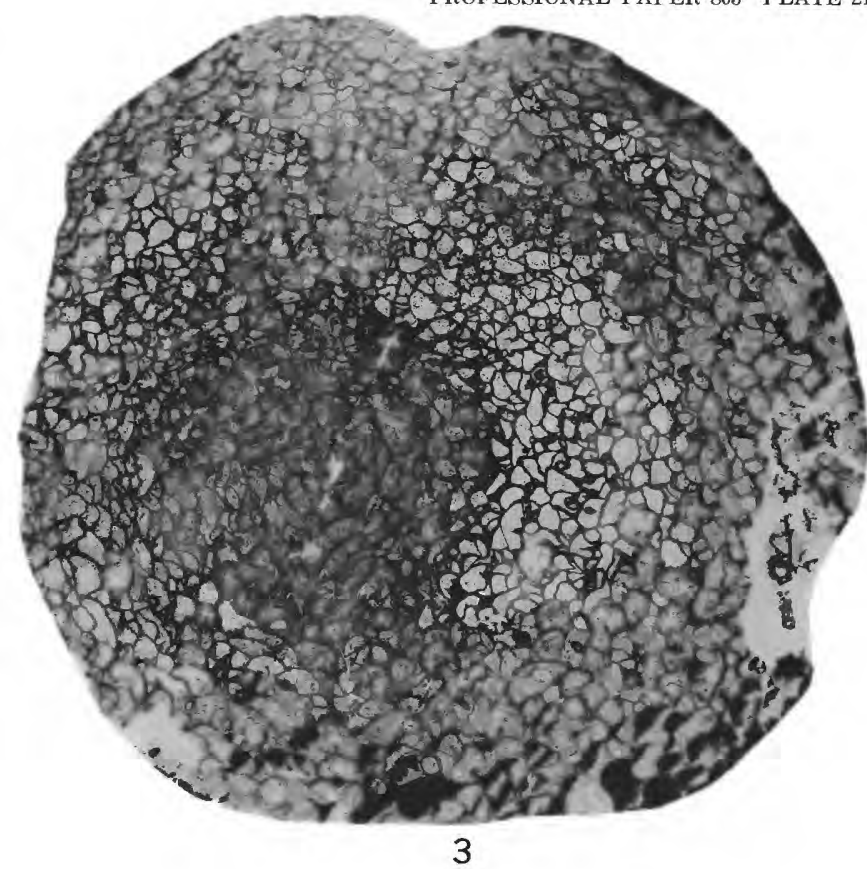

4

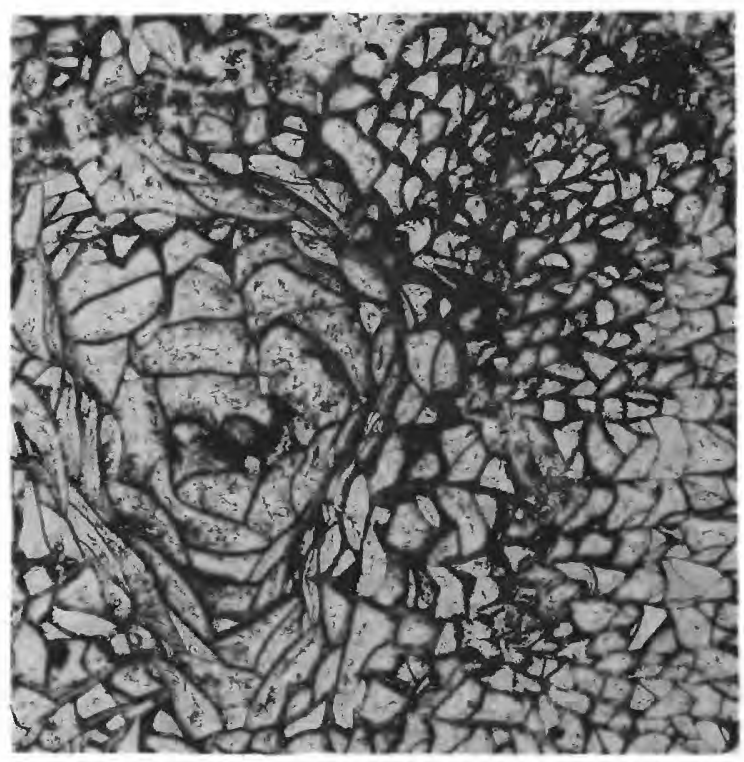




\section{PLATE 22}

FIGURES 1-6. Mesophyllum (Arcophyllum) kirki (Stumm).

1. Transverse thin section $(\times 2)$, USNM 159337

2. Transverse thin section $(\times 2)$, USNM 159338.

3. Enlargement of transverse thin section $(\times 4)$, USNM 159339.

4. Longitudinal thin section at calice $(\times 2)$, USNM 159340.

5. Longitudinal thin section $(\times 4)$, USNM 159341 .

6. Longitudinal thin section $(\times 2)$, USNM 159342 .

Middle Devonian, Nevada Formation, unit 2; Devonian coral zone $\mathrm{D}_{3}$. Locality M1036, northwest side of Lone Mountain, Eureka County, Nev. 

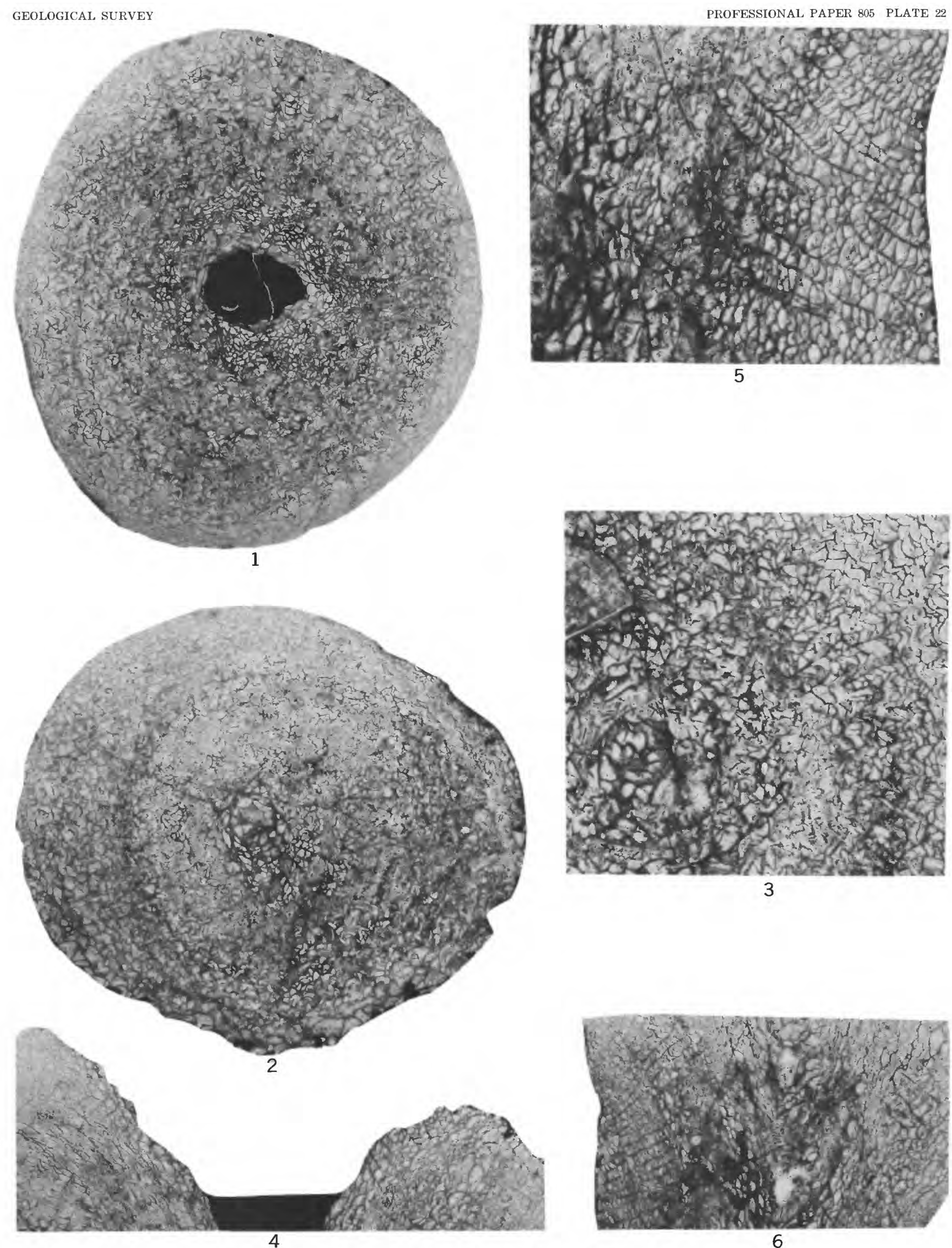

3

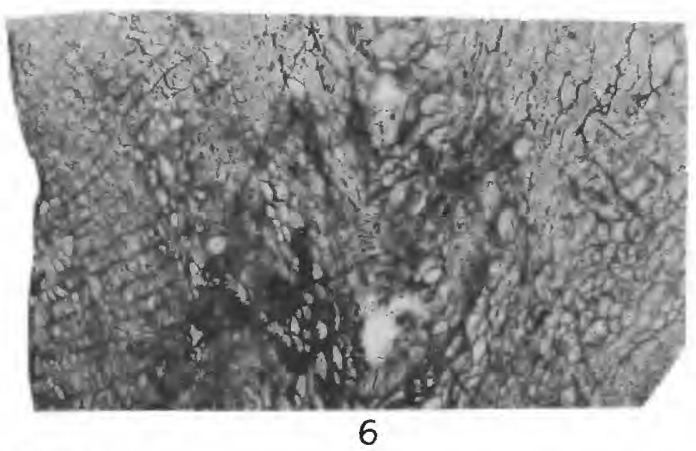

MESOPHYLLUM (ARCOPHYLLUM) 


\section{PLATE 23}

Figures 1-4. Cystiphylloides robertsense (Stumm).

Transverse, longitudinal, longitudinal, and transverse thin sections ( $\times$ 2), USNM 159343. Early Middle Devonian, Nevada Formation, unit 2; Devonian coral zone $\mathrm{D}_{2}$. Locality M1046, Lone Mountain, Eureka County, Nev.

5-10. Hexagonaria (Pinyonastraea) kirki (Stumm) n. subgen.

5,6 . Transverse and longitudinal thin sections of holotype $(\times 2)$, USNM 94456. Middle Devonian, Nevada Formation, unit 2; Devonian coral zone D. Lone Mountain, Eureka County, Nev.

7. Upper surface of large colony $(\times 1)$, USNM 159344. Middle Devonian, Nevada Formation, unit 2; Devonian coral zone $\mathrm{D}_{3}$. Locality M1052, northwest side of Lone Mountain, Eureka County, Nev.

8,9. Transverse and longitudinal thin sections $(\times 2)$, USNM 159345. Middle Devonian, Nevada Formation, unit 2; Devonian coral zone D. Locality M1053, north end of Antelope Range, Eureka County, Nevada.

10. Transverse print from stained cellulose peel $(\times 2)$. Middle Devonian, Nevada Formation, unit 2; Devonian coral zone D. Locality M1054, south side of Cooper Peak, Roberts Mountains, Nev. 


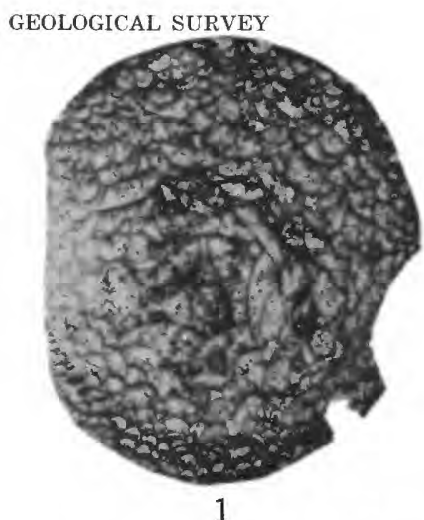

1

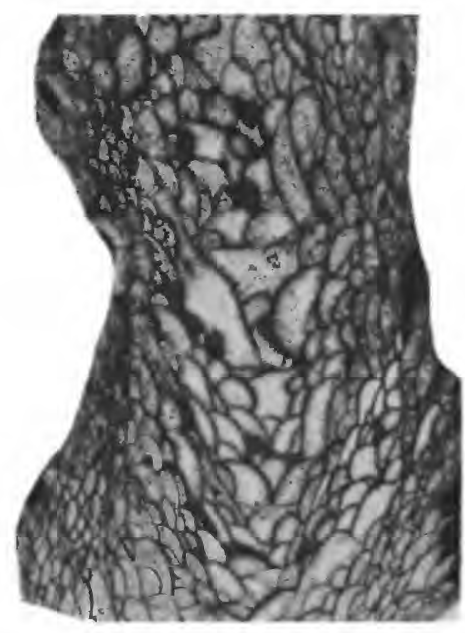

2

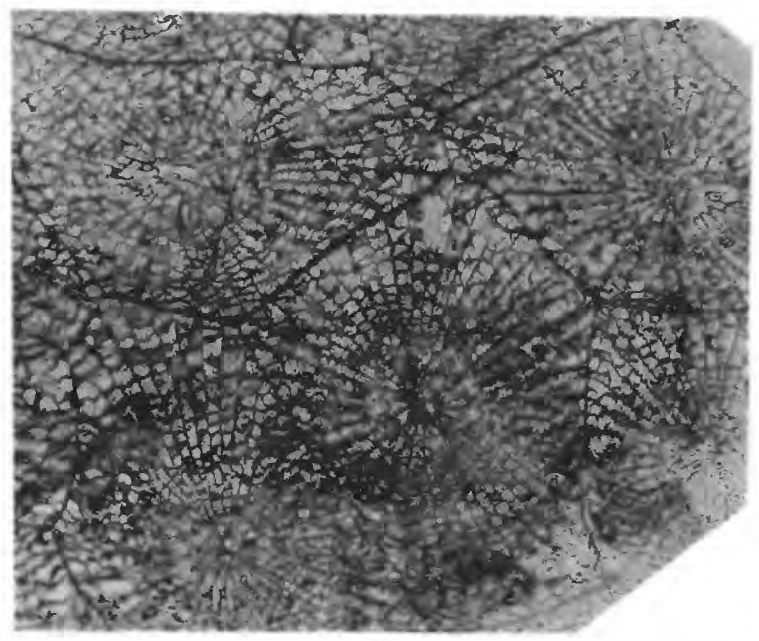

8

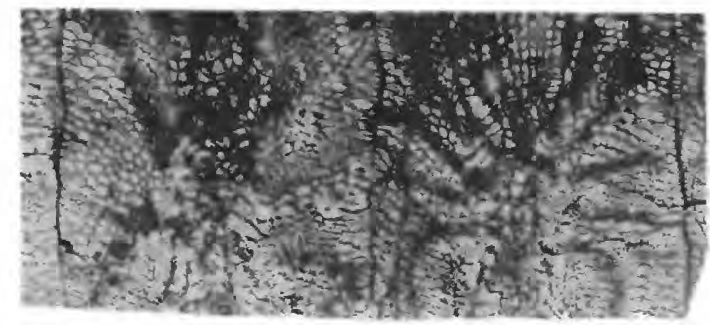

9
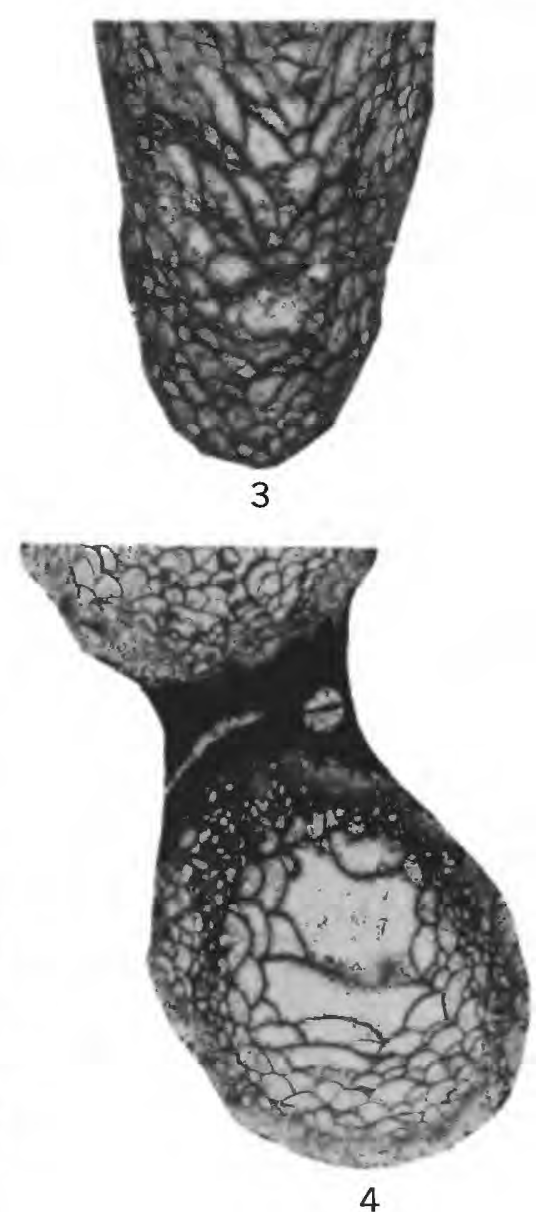

4

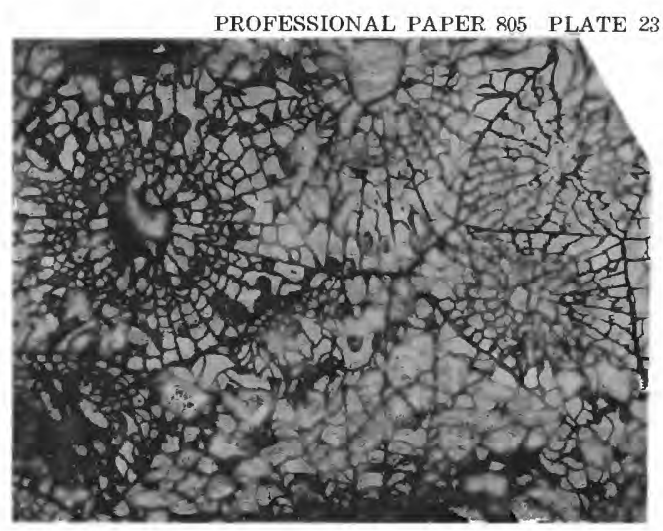

5

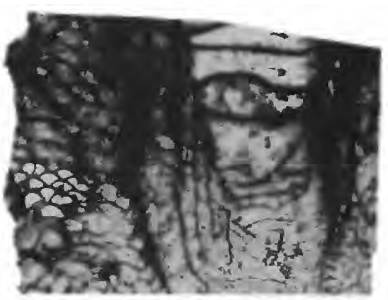

6

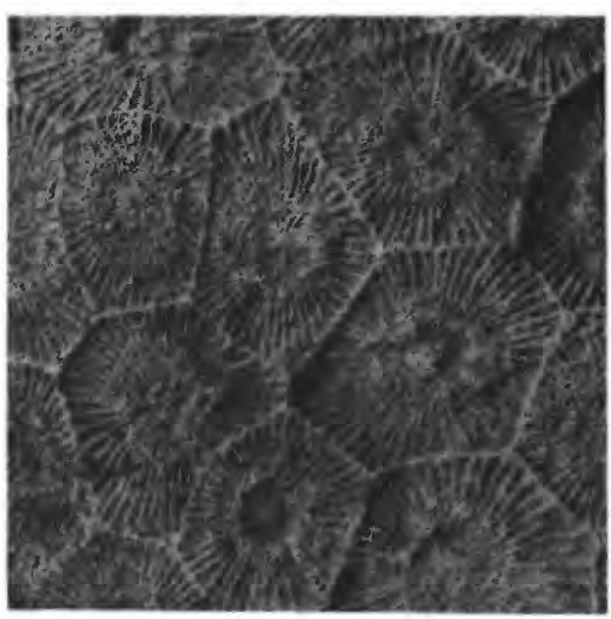

7

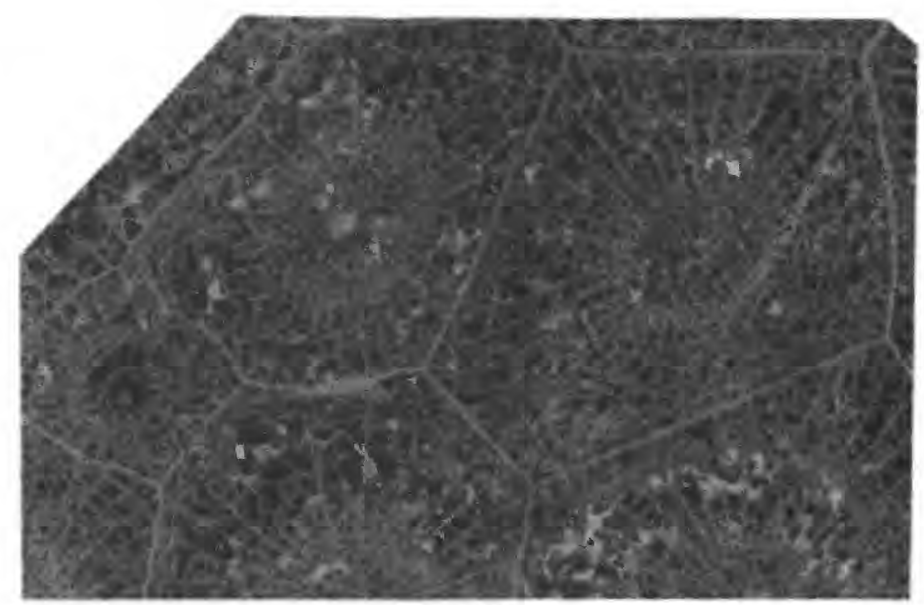

10

CYSTIPHYLLOIDES AND HEXAGONARIA (PINYONASTRAEA) 


\section{PLATE 24}

FIGURES 1-3. Billingsastraea nevadensis (Stumm).

Longitudinal thin section $(\times 2)$, surface of colony $(\times 1)$, and transverse thin section $(\times 2)$, USNM 159346. Early Middle Devonian, Nevada Formation, unit 2; Devonian coral zone $\mathrm{D}_{2}$. Locality M1055, north end Antelope Range, Eureka County, Nev.

4. Billingsastraea nevadensis subsp. arachne (Stumm).

Upper surface of colony ( $\times 1$ ), USNM 94458. Early Middle Devonian, Nevada Formation, unit 2; Devonian coral zone $\mathrm{D}_{2}$. Lone Mountain, Eureka County, Nev. Copy of Stumm's (1937, pl. 53, fig. 13) holotype figure.

5. Billingsastraea nevadensis (Stumm).

Transverse thin section $(\times 3)$, USNM 159347. Early Middle Devonian, Nevada Formation, unit 2; Devonian coral zone $\mathbf{D}_{2}$. Locality M1035, north end Antelope Range, Eureka County, Nev.

6-8. Billingsastraea nevadensis (Stumm).

6. Longitudinal thin section $(\times 4)$, USNM 159348.

7. Transverse thin section $(\times 4)$, USNM 159349.

8. Longitudinal thin section $(\times 4)$, USNM 159350.

Early Middle Devonian, Nevada Formation, unit 2; Devonian coral zone $\mathbf{D}_{2}$. Locality M55, Lone Mountain, Eureka County, Nev. 
GEOLOGICAL SURVEY

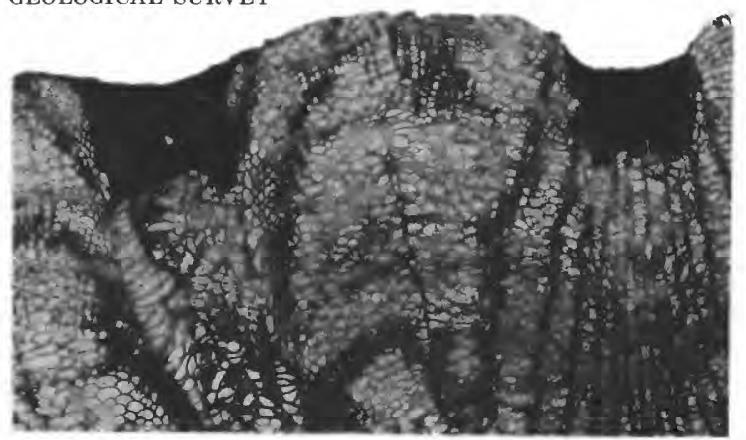

1

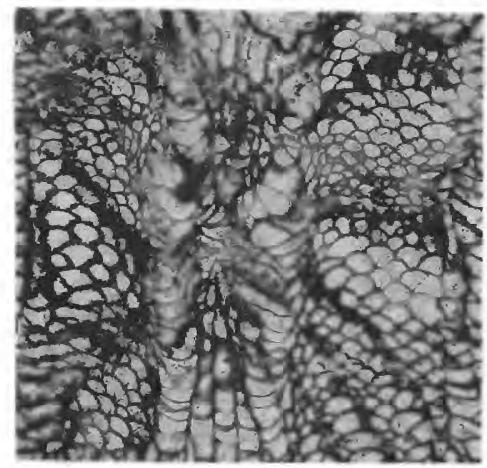

6

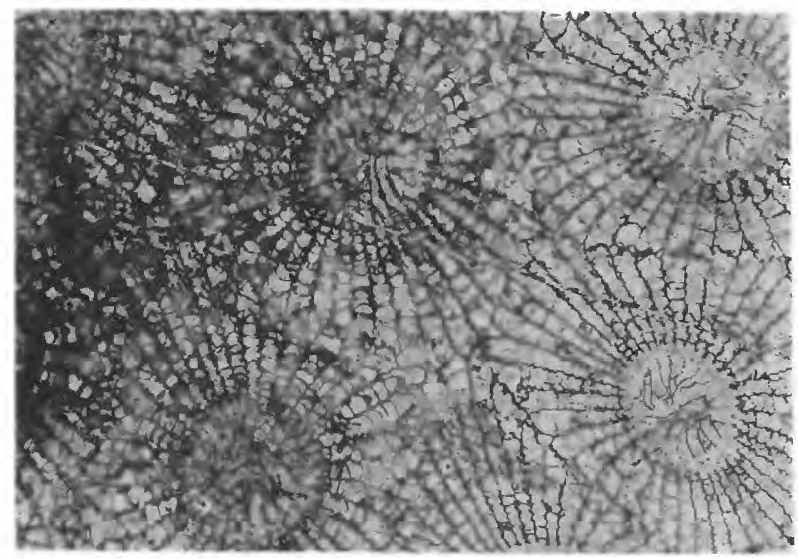

3

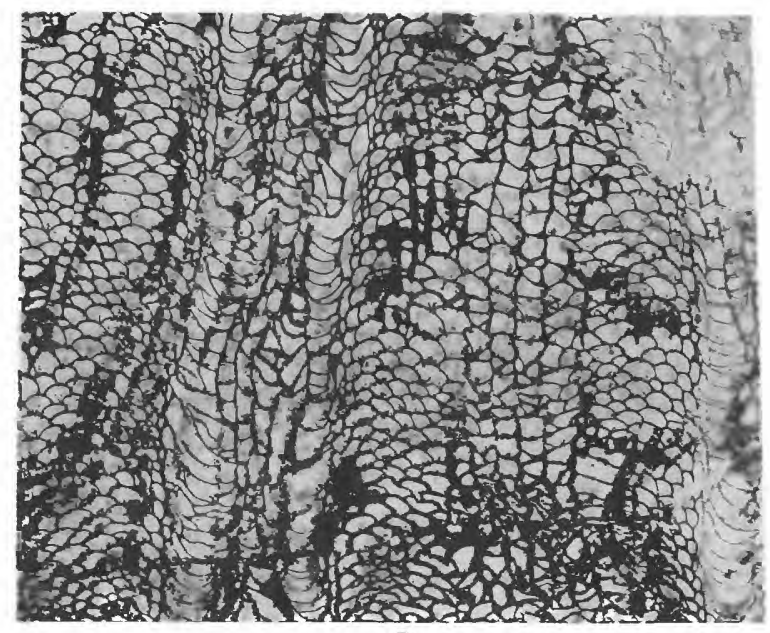

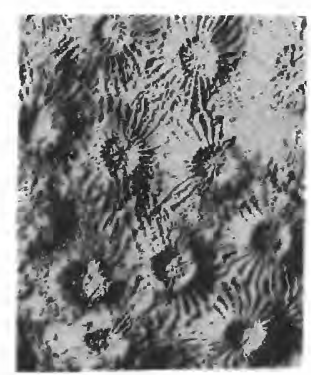

4

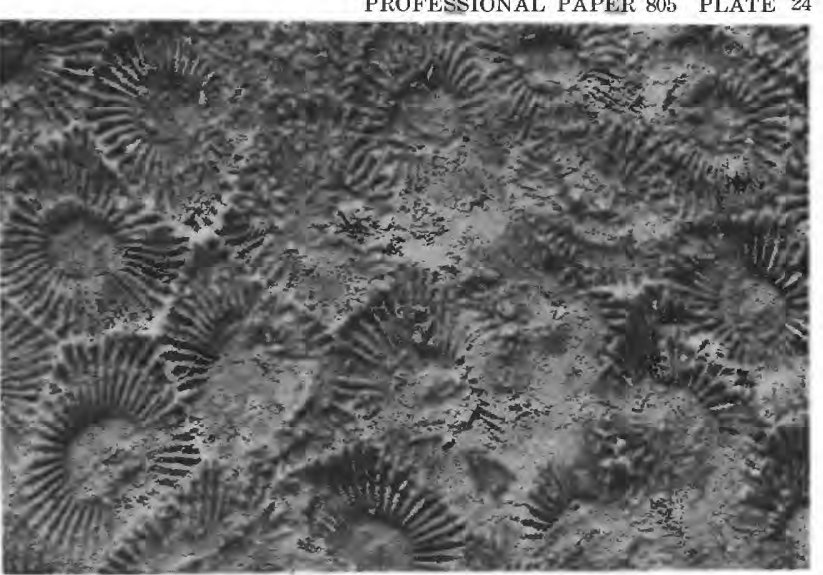

2

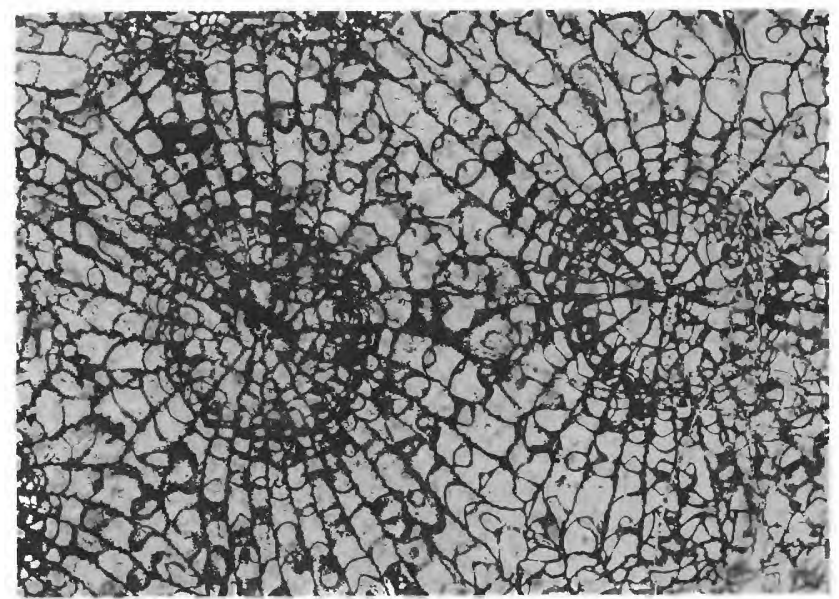

5

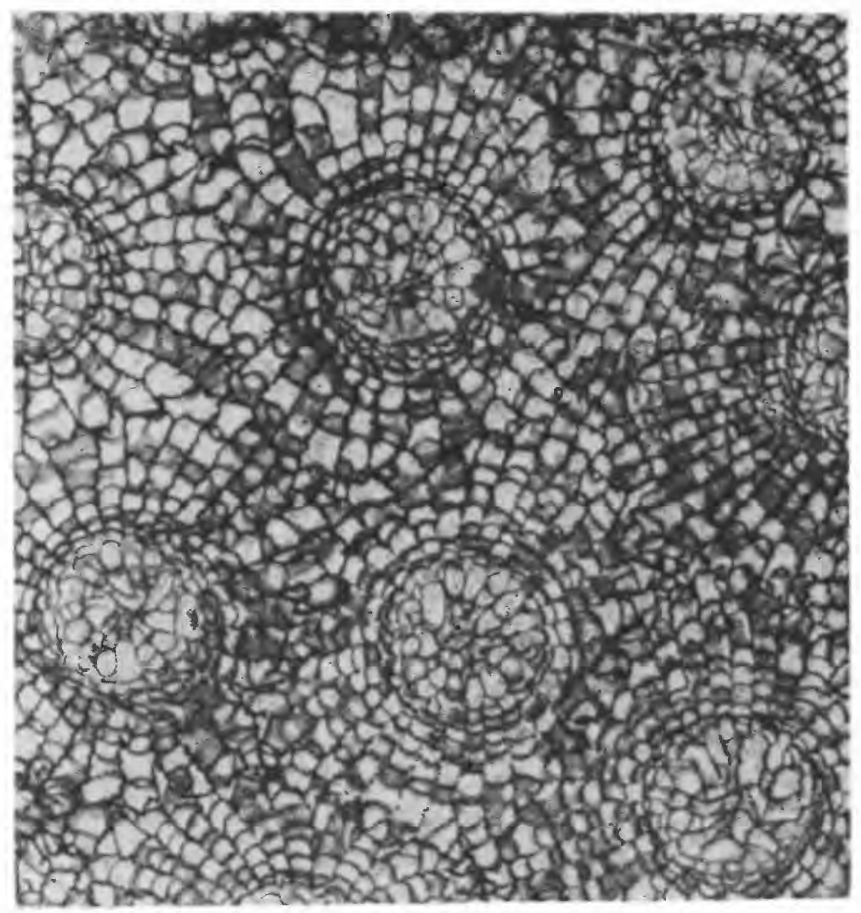

7 


\section{PLATE 25}

FiguRES 1-4. Australophyllum landerensis n. sp.

1,2. Transverse thin section $\left(\times 2 \frac{1}{2}\right)$ and longitudinal thin section $\left(\times 2 \frac{1}{2}\right)$ of holotype USNM 159353.

3 ,4. Longitudinal and transverse thin sections $(\times 2)$ of paratype USNM 159354.

Early Devonian, Rabbit Hill Limestone. Locality M1150, north end of Toquima Range.

5. Australophyllum sp.

Transverse thin section $(\times 2)$. Upper Silurian or lowermost Devonian just above Silurian coral zone E, upper unit of Vaughn Gulch Limestone. Locality M1093, Mazourka Canyon, northern Inyo Mountains, Calif.

6-9. Billingsastraea? sp. T.

6, 7. Transverse thin sections $(\times 2, \times 3)$.

8,9. Longitudinal thin sections $(\times 3)$.

All sections cut from same colony. Middle Devonian. Locality M1151, Reeds Canyon area, Toiyabe Range.

10. (?) Hexagonaria sp.

Transverse thin section $(\times 2)$. Same locality and horizon as figures 6-9. 


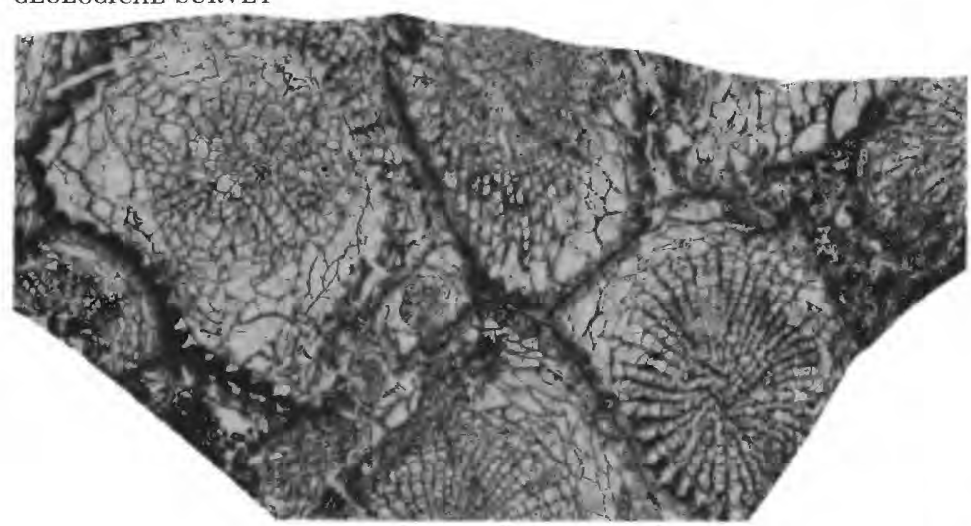

1
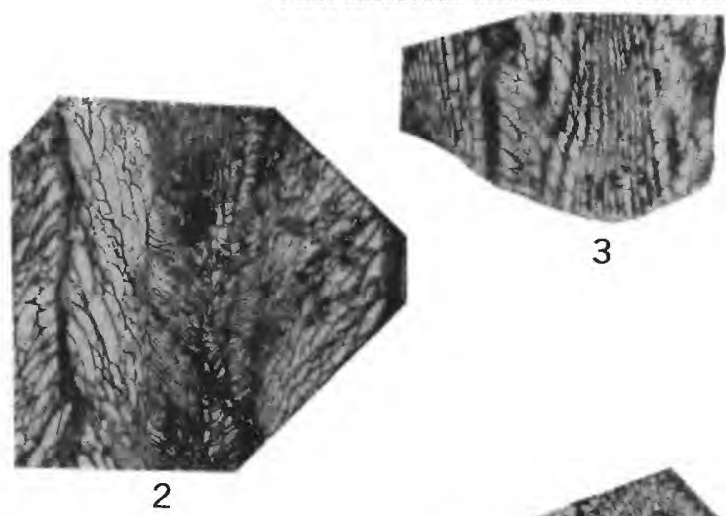

3

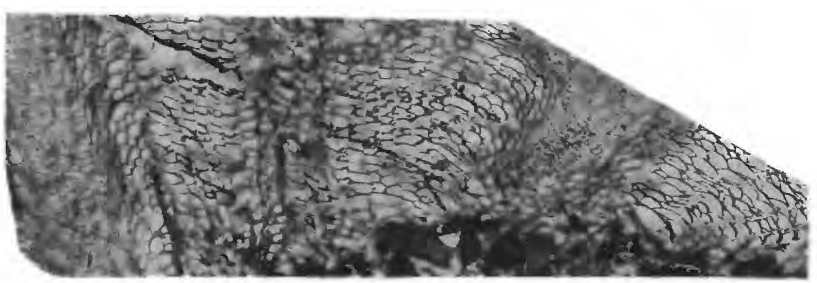

8
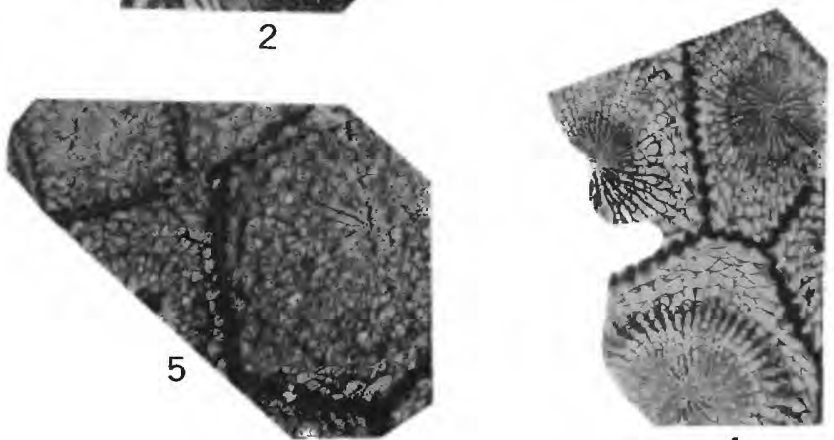

4

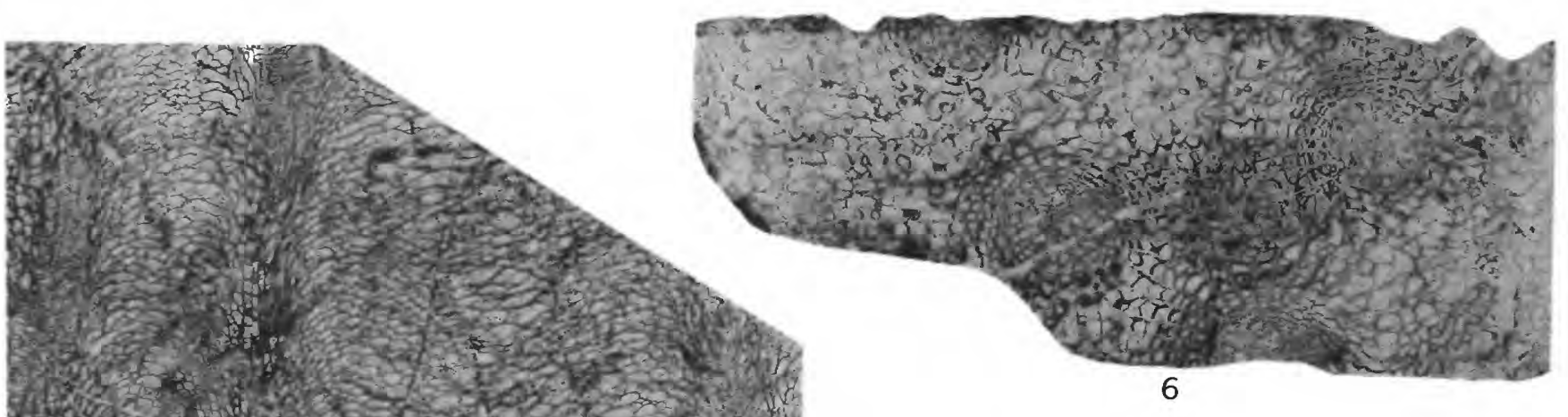

9

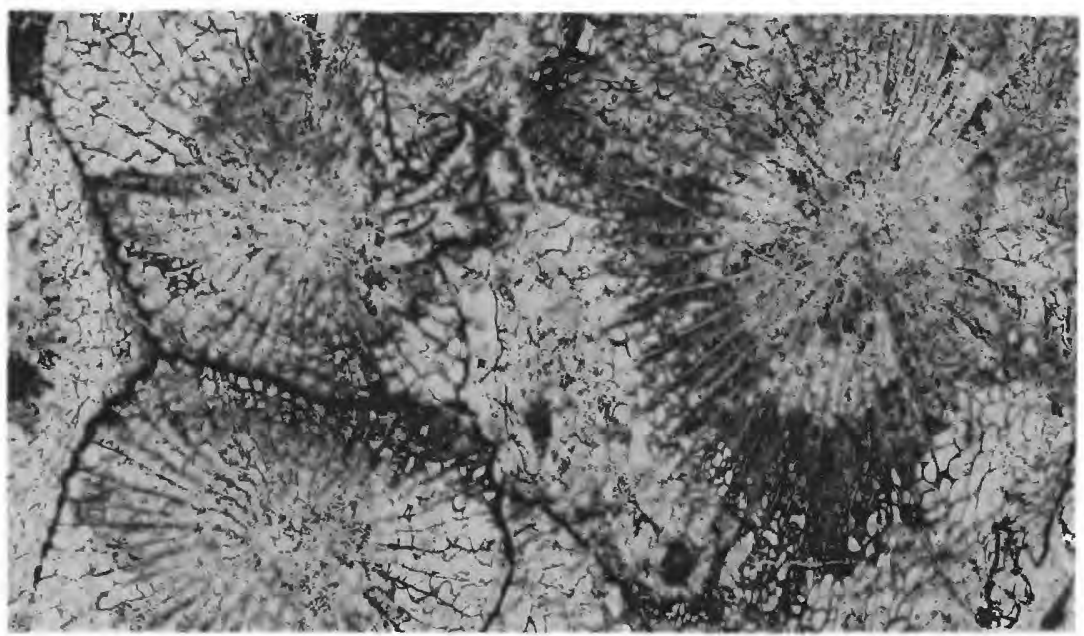

10

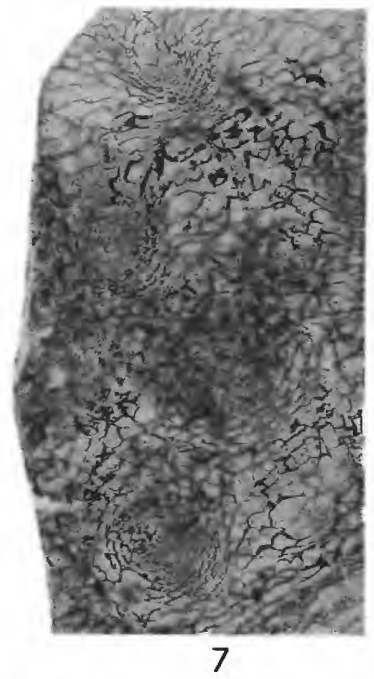

AUSTRALOPHYLLUM, BILLINGSASTRAEA?, AND (?)HEXAGONARIA 